ANGELO JUST DA COSTA E SILVA

MÉTODO PARA GESTÃO DAS ATIVIDADES DE MANUTENÇÃO DE REVESTIMENTOS DE FACHADA

São Paulo

2008 
ANGELO JUST DA COSTA E SILVA

\section{MÉTODO PARA GESTÃO DAS ATIVIDADES DE MANUTENÇÃO DE REVESTIMENTOS DE FACHADA}

Tese apresentado à Escola Politécnica da Universidade de São Paulo para obtenção do título de Doutor em Engenharia Civil.

Área de Concentração:

Engenharia de Construção Civil

Orientador:

Prof. Dr. Luiz Sérgio Franco

São Paulo 
Este exemplar foi revisado e alterado em relação à versão original, sob responsabilidade única do autor e com a anuência de seu orientador.

São Paulo, 23 de setembro de 2008.

Assinatura do autor

Assinatura do orientador

\section{FICHA CATALOGRÁFICA}

Costa e Silva, Angelo Just da

Método para gestão das atividades de manutenção de revestimentos de fachada / A.J.Costa e Silva. -- São Paulo, 2008.

221 p.

Tese (Doutorado) - Escola Politécnica da Universidade de São Paulo. Departamento de Engenharia de Construção Civil.

1. Patologia das construções 2 . Revestimento de fachadasI.Universidade de São Paulo. Escola Politécnica. Departamento de Engenharia de Construção Civil II.t. 


\section{AGRADECIMENTOS}

A elaboração de um trabalho como este, em verdade, além do meu esforço pessoal contou com a contribuição e esforço de várias pessoas, às quais dedico a seguir algumas palavras de reconhecimento.

Tenho diversas razões para agradecer ao meu orientador, Luiz Sérgio Franco, em especial por acreditar na realização do trabalho, mesmo à distância. Acredito que o bom orientador é aquele que indica os caminhos nos momentos cruciais, como aconteceu conosco, e tenho certeza que nossa mútua confiança foi essencial para a conclusão do estudo. Estive com ele no mestrado e também agora no doutorado, e repetiria tudo do mesmo jeito, caso fosse preciso.

Minha referência profissional é o Prof. Joaquim Correia. Costumo dizer que não trabalho para ele, e sim com ele, o que é muito diferente. Nas diversas vezes que precisei ir a São Paulo não houve sequer um senão. Coisa de quem é generoso, e me faz lhe ter o carinho que um filho tem por um pai.

Agradeço, na verdade, a todos que compõem a Tecomat, empresa que me apóia em tudo o que faço. Às vezes até no que apenas penso em fazer. A Tibério, meu irmão e apoio já há tantos anos, a Sandra, a Neto, e a todos, enfim.

Tenho de agradecer também a quem me abriu as portas acadêmicas, meu amigo Zé Orlando. Tenho o prazer da sua convivência diária na Universidade Católica de Pernambuco, e por isso o personalizo no agradecimento a esta instituição que tanto me dá suporte.

Agradeço a todos os especialistas que participaram ou ajudaram durante a pesquisa de validação presente no estudo, respondendo aos questionamentos por acreditarem na seriedade do trabalho. Vocês fazem ciência.

No campo pessoal, tenho vários amigos a agradecer. Fiz grandes amizades nos tempos em que estive em Sampa, e as personifico no Manolo, um cara de bem com a vida e que admiro pela forma como se dedicou a conhecer e amar a nossa cultura. Coisa de quem é sábio, apesar da pouca idade. 
Dentre os pernambucanos, tenho carinho por todos, e por dois caras em especial. Flávio Maranhão, que muito admiro pelo seu caráter genuíno, e que tantas vezes me acolheu na sua casa da forma mais gentil que podia. Aluizio Caldas, fiel e maior companheiro nos difíceis momentos de Sampa, cujo coração é de pura generosidade.

Aos meus pais, Chico e Sônia, meus irmãos e todos os seus, essas palavras são poucas para agradecer pela educação, princípios, valores, ou seja, coisas que não se aprendem na escola.

Por fim, agradeço e dedico esse trabalho a Ana Cláudia Serra Silva, meu amor e minha família para o resto da vida. 
"Tudo de bom que acontece em minha vida apresso-me em registrar. Os sentimentos validados nos símbolos gráficos para que não me escapem. Escrevo qualquer coisa. Escrevendo enxergo com mais clareza, organizo melhor o pensamento, uma conversa comigo mesma"

Sônia Just - Contos de Oficina nํ 04 


\section{RESUMO}

A necessidade crescente de atividades de manutenção em edificações habitadas, e sua inerente complexidade, tornam a adoção de métodos de gestão de extrema importância para a realização de obras com desempenho técnico e operacional eficientes.

Assim, a presente pesquisa discute proposta de método para gestão de obras de manutenção de revestimentos de fachada, concebido em decorrência da necessidade de consolidação de técnicas eficientes para condução desse tipo de atividade.

A pesquisa contempla uma fase inicial exploratória que aborda aspectos conceituais fundamentais e descreve relatos de casos acompanhados pelo autor em que as técnicas de gestão foram adotadas de forma não sistêmica, e cuja análise crítica gerou informações importantes para a elaboração da proposta. Em seguida o trabalho mostra a proposição inicial do método, elaborada a partir das discussões relatadas posteriormente na bibliografia e nas considerações oriundas da fase inicial exploratória.

Para avaliação da proposta foi realizada uma validação interna de conteúdo, a partir de pesquisas orientadas com especialistas escolhidos mediante critérios de seleção prédefinidos, utilizando método Delphi. Como atividade complementar, foi ainda discutida a eficiência das ações propostas por meio de um estudo de caso prático. As respostas obtidas em ambos os casos indicaram a adequação das ações propostas, o que possibilitou a apresentação do método de gestão final consolidado, considerado cientificamente eficiente.

Palavras-chave: manutenção predial, fachada, método Delphi, validação. 


\begin{abstract}
The increasing need for inherently complex maintenance activities in inhabited buildings makes the adoption of management methods a very important tool for the execution of technically and operationally efficient projects.

This research presents the proposal of a method for the management of façade covering maintenance construction projects, conceived as a result of the need for the consolidation of efficient techniques to conduct this type of activity.

The research starts with an exploratory phase that addresses fundamental conceptual aspects and describes cases where management techniques were not formally adopted. This critical analysis generated important information for the elaboration of the method. Then the work presents the initial proposal of the method, devised from the discussions subsequently reported in the literature and in the considerations from the initial exploratory phase.

For the evaluation of the proposal, an internal validation of content was carried out by means of a guided poll with specialists chosen through pre defined selection criteria using the Delphi Method. As a complementary activity, a practical case study was done in order to assess the efficiency of the method. The feedback obtained in both cases indicated the appropriateness of the proposed actions, allowing the presentation of the final management method, considered to be scientifically efficient.
\end{abstract}

Keywords: maintenance buildings, façade, Delphi method, validation. 


\section{LISTA DE FIGURAS}

Figura 1 - Ações propostas para a gestão de obras de manutenção de fachadas. 2

Figura 2 - Desenho explicativo da estruturação utilizada para o desenvolvimento do texto. ..4 Figura 3 - Descrição das ações básicas para gestão das atividades de manutenção em revestimentos de fachada. 22

Figura 4 - Descrição das ações tomadas durante o diagnóstico das necessidades do prédio.

Figura 5 - Esquema de representação de graus de deterioração na fachada apresentado por Gaspar, Brito (2005). 58

Figura 6 - Descrição de áreas de descolamento de revestimento de fachada (Costa e Silva, 2001)

Figura 7 - Exemplo de gráfico de barra para acompanhamento do cronograma físico da obra.

Figura 8 - Fluxograma das atividades realizadas para a validação interna.

Figura 9 - Imagem extraída do site explicando as informações apresentadas aos especialistas na $2^{\mathrm{a}}$ rodada. 143

Figura 10 - Atividade inicial da gestão. 176

Figura 11 - Descrição das atividades propostas para a avaliação das necessidades do prédio.

Figura 12 - Descrição das atividades propostas para a contratação da empresa executante.

Figura 13 - Descrição das atividades propostas para o acompanhamento dos serviços.......184

Figura 14 - Vista geral da fachada sul e caixa de escada (concluído - janeiro 2005). 201

Figura 15 - Vista geral da fachada leste (concluído - janeiro 2005). 201

Figura 16 - Detalhe da recomposição do revestimento em procelanto 202

Figura 17 - Vista da fachada norte durante a obra (setembro de 2003). 202 
Figura 18 - Vista geral da fachada principal (original).

Figura 19 - Detalhe de trecho com queda do revestimento cerâmico da varanda. 203

Figura 20 - Aspecto de trecho com estufamento do revestimento cerâmico original. 204

Figura 21 - Vista geral da fachada norte original (junho 2003). 205

Figura 22 - Execução do revestimento caixa de escada fachada norte (agosto 2004). 205

Figura 23 - Vista geral da fachada sul (original com limpeza - agosto 2004). 206

Figura 24 - Vista geral das fachadas sul e leste e área social mezanino (concluído - dezembro 2004) 206

Figura 25 - Vista da fachada leste (poente) 207

Figura 26 - Detalhe de trecho da fachada poente com queda de revestimento cerâmico. ..207 


\section{LISTA DE GRÁFICOS}

Gráfico 1 - Expressão gráfica da queda de desempenho natural de uma edificação com o tempo (extraído de Lichtenstein (1985)). 32

Gráfico 2 - Evolução do desempenho da edificação após as atividades de manutenção (adaptado de Lichtenstein (1985)). 33

Gráfico 3 - Gráfico ilustrativo do aumento do custo com manutenção com o passar do tempo (Lei de Sitter) 34

Gráfico 4 - Exemplo do crescimento exponencial do custo de manutenção com o tempo (adaptado de Alani et al.(2001)). 35 


\section{LISTA DE TABELAS}

Tabela 1 - Relação de fatores de sucesso para a implementação da gestão de obra de manutenção (adaptado de Attalla; Hegazy, 2003).

Tabela 2 - Descrição de agentes e suas funções no desenvolvimento de atividades (adaptado de Gehbauer, 2004). 35

Tabela 3 - Descrição das características básicas dos casos em estudo. 38

Tabela 4 - Prazos de execução previstos e executados nas obras em estudo.

Tabela 5 - Tabela indicativa dos preços de referência, propostas apresentadas pelas empresas concorrentes, orçamento contratado e executado.

Tabela 6 - Aspectos particulares de contrato observados nas obras em estudo. 45

Tabela 7 - Discussão da origem de fatores de sucesso (e insucesso) relevantes observados nas obras em estudo (I - Avaliação das necessidades do prédio, II - Aspectos de contrato ( $a$ - projeto executivo, $b$ - questões financeiras, $c$ - questões técnicas, $d$ questões operacionais), III - acompanhamento).

Tabela 8 -Descrição da proposta inicial apresentada para a gestão das obras de manutenção em revestimentos de fachada.

Tabela 9 - Classificação dos elementos construtivos (Barrientos e Qualharini, 2004). 68

Tabela 10 - Fontes de erros em orçamentos de obras (adaptado de Parker, 1994). 75

Tabela 11 - Características inerentes à atividade de seleção dos profissionais de engenharia e arquitetura (Christodoulou et al., 2004).

Tabela 12 - Limites de resistência de aderência à tração (NBR 13749, ABNT (1996)).

Tabela 13 - Perfil dos participantes da validação interna de conteúdo. 146

Tabela 14 - Critérios de análise das respostas adotados na pesquisa 154

Tabela 15 - Critério adotado para definição das escalas de prioridade dentre as propostas enquadradas na classe $B$. 
Tabela 16 - Resultados obtidos nos questionamentos referentes ao Grupo 1: Aspectos fundamentais da proposta metodológica (I - Irrelevante, II - Pouco relevante, III Muito relevante, IV - Imprescindível)

Tabela 17 - Resultados obtidos nos questionamentos referentes ao Grupo 2: Diagnóstico das necessidades (I - Irrelevante, II - Pouco relevante, III - Muito relevante, IV Imprescindível)

Tabela 18 - Resultados obtidos nos questionamentos referentes ao Grupo 3: Discussão de prazos e custos (I - Irrelevante, II - Pouco relevante, III - Muito relevante, IV Imprescindível) 160

Tabela 19 - Resultados obtidos nos questionamentos referentes ao Grupo 4: Seleção das empresas (I - Irrelevante, II - Pouco relevante, III - Muito relevante, IV Imprescindível) 161

Tabela 20 - Resultados obtidos nos questionamentos referentes ao Grupo 5: Contratação (I Irrelevante, II - Pouco relevante, III - Muito relevante, IV - Imprescindível) 163

Tabela 21 - Resultados obtidos nos questionamentos referentes ao Grupo 6: Acompanhamento (I - Irrelevante, II - Pouco relevante, III - Muito relevante, IV Imprescindível) 168

Tabela 22 - Resultados obtidos no questionamento referente ao Grupo 7: Aspectos finais (I Irrelevante, II - Pouco relevante, III - Muito relevante, IV - Imprescindível) 170

Tabela 23 - Análise da avaliação das necessidades do prédio realizada no estudo de caso. 171 Tabela 24 - Análise dos critérios para a seleção e contratação realizada no estudo de caso. 


\section{SUMÁRIO}

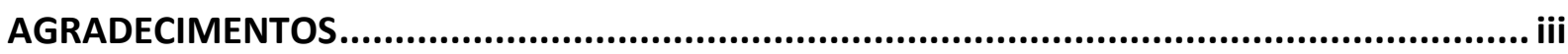

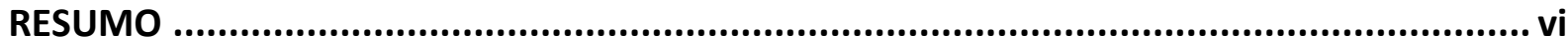

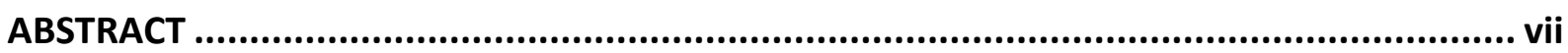

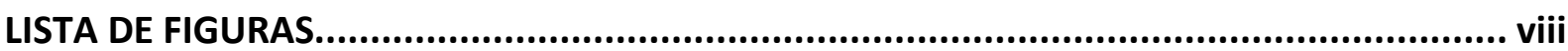

LISTA DE GRÁFICOS

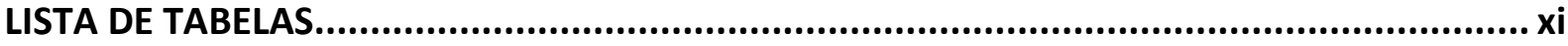

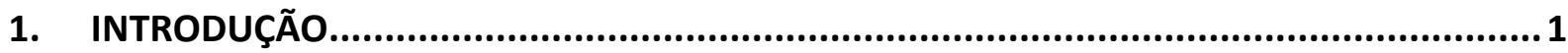

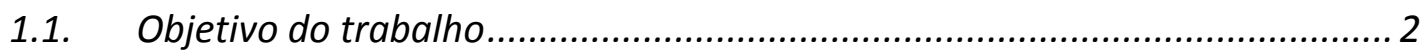

1.2. Objeto e limitações do estudo ............................................................... 3

1.3. Estruturação do trabalho .................................................................... 3

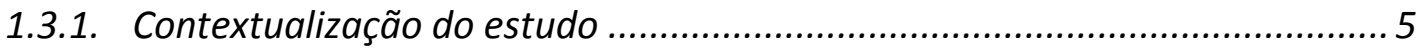

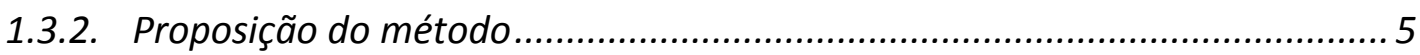

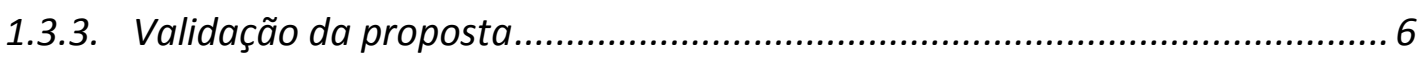

2. CONSIDERAÇÕES SOBRE O TEMA E ABORDAGEM CONCEITUAL ................................9

2.1. Justificativas para o desenvolvimento da pesquisa................................... 9

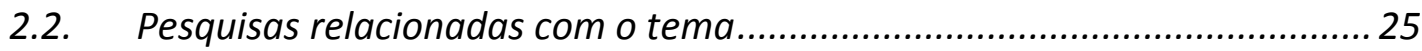

2.3. Manutenção - conceituação ............................................................... 30

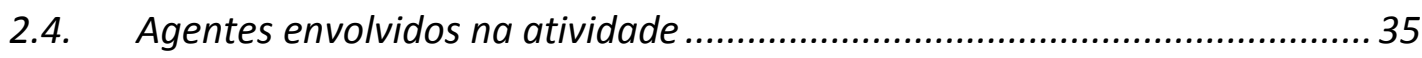

3. FASE EXPLORATÓRIA - EXPOSIÇÃO DE CASOS NÃO ORIENTADOS .............................. 38

3.1. Avaliação das necessidades do prédio ................................................... 40

3.2. Análise e critérios para a contratação................................................... 41

3.3. Acompanhamento dos serviços ....................................................... 46 


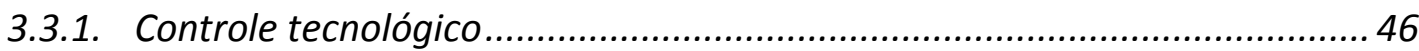

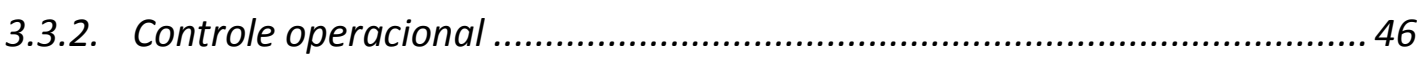

4. GESTÃO DE OBRAS DE MANUTENÇÃO EM FACHADA ...........................................50

4.1. Avaliação das necessidades para intervenção ..........................................5 53

4.1.1. Diagnóstico das necessidades do prédio ...............................................53

4.1.1.1.Descrição do edifício e anamnese do problema ........................................55

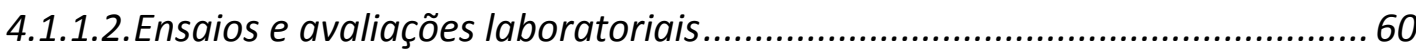

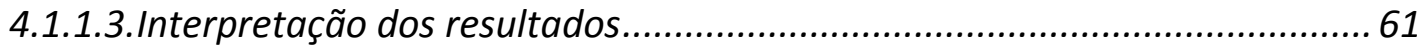

4.1.1.4.Avaliação da situação encontrada / Diagnóstico das causas prováveis ...... 62

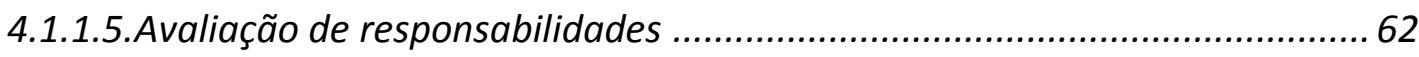

4.1.2. Alternativas de intervenção e tomada de decisão ......................................66

4.2. Análise e critérios para a contratação........................................................ 71

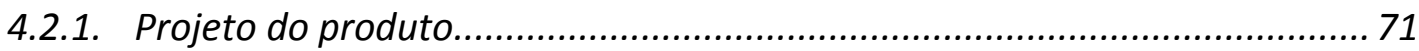

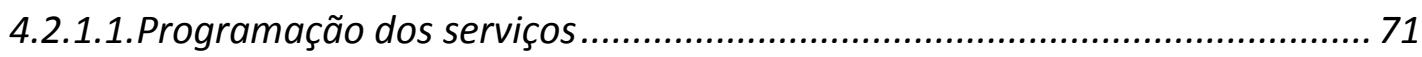

4.2.1.2. Orçamento e levantamento de custos...................................................... 74

4.2.2. Seleção das empresas concorrentes - procedimento e critérios de escolha 78

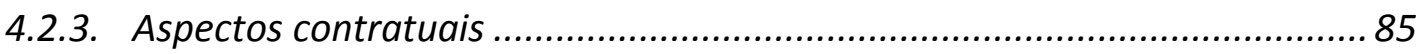

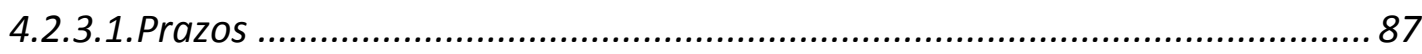

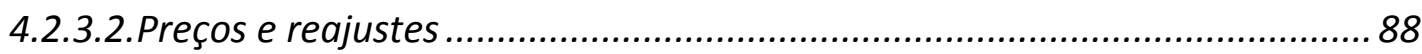

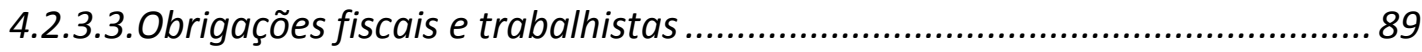

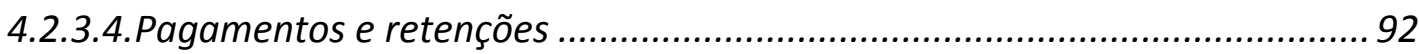

4.2.3.5. Escopo do serviço e equipamentos ......................................................... 93

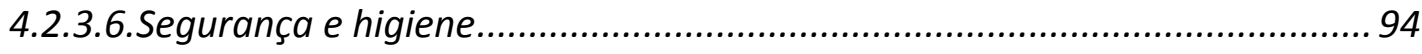

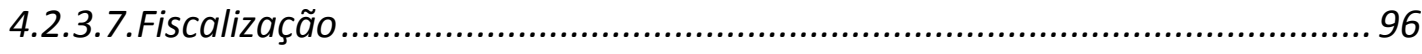

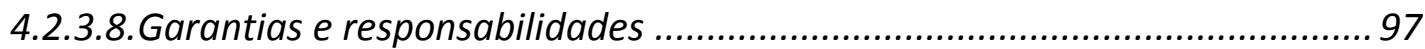




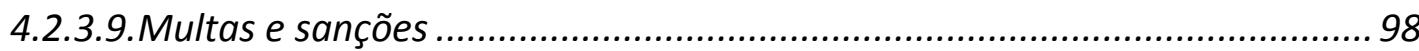

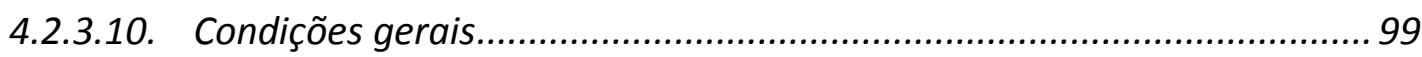

4.3. Acompanhamento dos serviços....................................................... 101

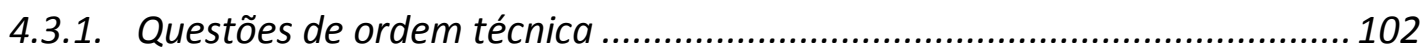

4.3.1.1.Controle tecnológico - materiais ............................................................... 105

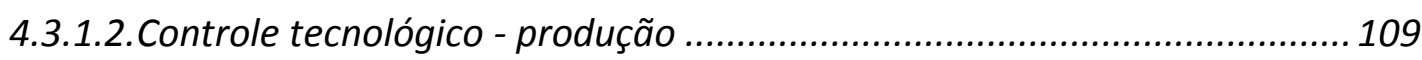

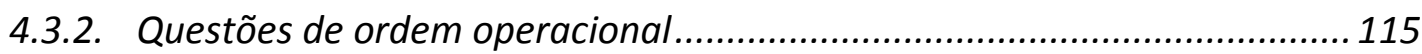

4.3.2.1.Acompanhamento dos prazos e suas repercussões ................................ 115

4.3.2.2. Precauções quanto a problemas futuros fiscais e trabalhistas ................. 119

4.3.2.3. Prevenção dos distúrbios diversos aos usuários do imóvel ....................... 120

5. ESTUDO DE VALIDAÇÃO - CONCEITOS E MÉTODO .......................................... 125

5.1. Discussões sobre o método Delphi ........................................................ 126

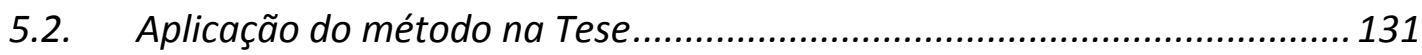

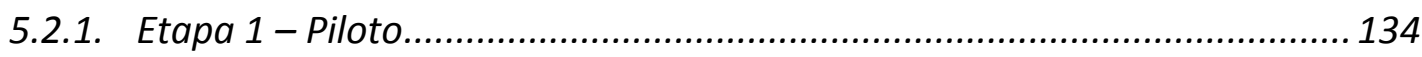

5.2.2. Etapa 2 - 1므 rodada de perguntas ................................................... 141

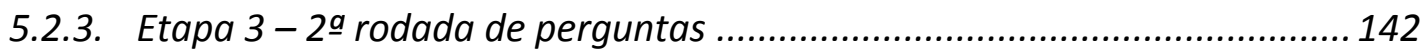

5.3. Avaliação da aplicabilidade das propostas em estudo de caso ................. 147

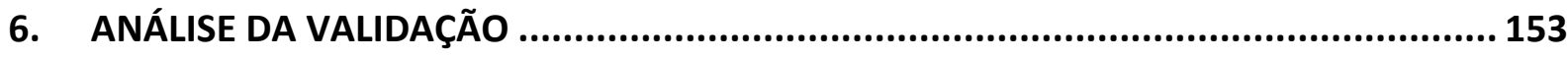

6.1. Validação interna de conteúdo.......................................................... 153

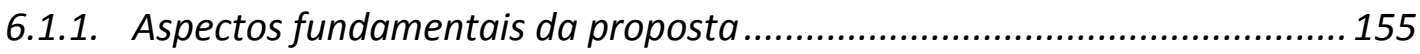

6.1.2. Diagnóstico das necessidades do prédio ................................................. 156

6.1.3. Análises e critérios para a contratação ................................................. 160

6.1.4. Acompanhamento dos serviços......................................................... 168

6.2. Discussões realizadas no estudo de caso ............................................. 171 


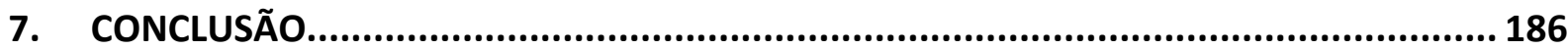

7.1. Quanto à importância do tema ........................................................... 186

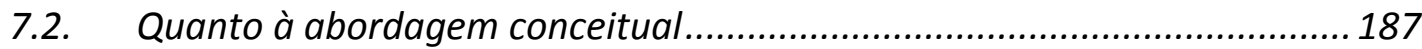

7.3. Quanto ao método de gestão proposto .............................................. 188

7.4. Quanto ao método de validação ............................................................. 189

7.5. Quanto à aplicabilidade do método em campo ...................................... 190

7.6. Recomendações para estudos futuros ................................................. 191

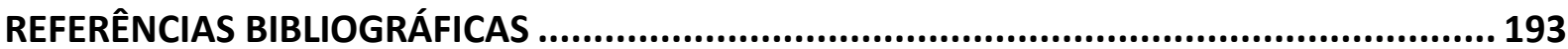

ANEXO A - REGISTRO FOTOGRÁFICO DOS CASOS APRESENTADOS NA FASE EXPLORATÓRIA200

ANEXO B - DIAGRAMAÇÃO DO SITE UTILIZADO NA PESQUISA ..................................... 208

ANEXO C - EXEMPLO DE CARTA CONSULTA (DOCUMENTO DE INTENÇÕES) ................... 210 


\section{INTRODUÇÃO}

O presente trabalho foi concebido a partir das observações realizadas pelo autor das dificuldades encontradas por síndicos e administradores de condomínios para a condução dos serviços de manutenção nas respectivas edificações ou em suas partes, em especial na fachada.

A complexidade de fatores técnicos e operacionais envolvidos nesse tipo de obra demanda a realização de pesquisas com o objetivo de orientar os agentes participantes no sentido de se assegurar uma adequada intervenção.

O problema levantado no trabalho é:

- Considerando uma edificação que esteja apresentando algum tipo de deficiência no revestimento de fachada que necessite de uma intervenção, responder às seguintes questões:

- Qual a solução técnica indicada para o problema?

- Como conduzir a obra para reduzir os transtornos para os usuários?

- Como proceder para contratar esses serviços resguardando os interesses dos envolvidos?

○ De que maneira se pode garantir a adequada execução dos serviços?

O contexto complicador nesses casos decorre da "distância" entre os principais agentes envolvidos (síndicos, ou administradores de condomínio, e construtores). Com isso, o presente trabalho é voltado para a descrição das ações a serem desenvolvidas por um profissional (ou empresa) especialista, doravante descrito como gerenciador(a), que devem ter como objetivo principal reduzir as referidas distâncias, facilitando o entendimento entre as partes.

A execução de um trabalho dessa magnitude envolve uma série de etapas de gestão, que se inicia pela avaliação das necessidades da edificação, seguida pela discussão de critérios para a escolha e a contratação, e se completa durante o acompanhamento dos serviços, conforme descreve a Figura 1, que resume as ações propostas na pesquisa. 


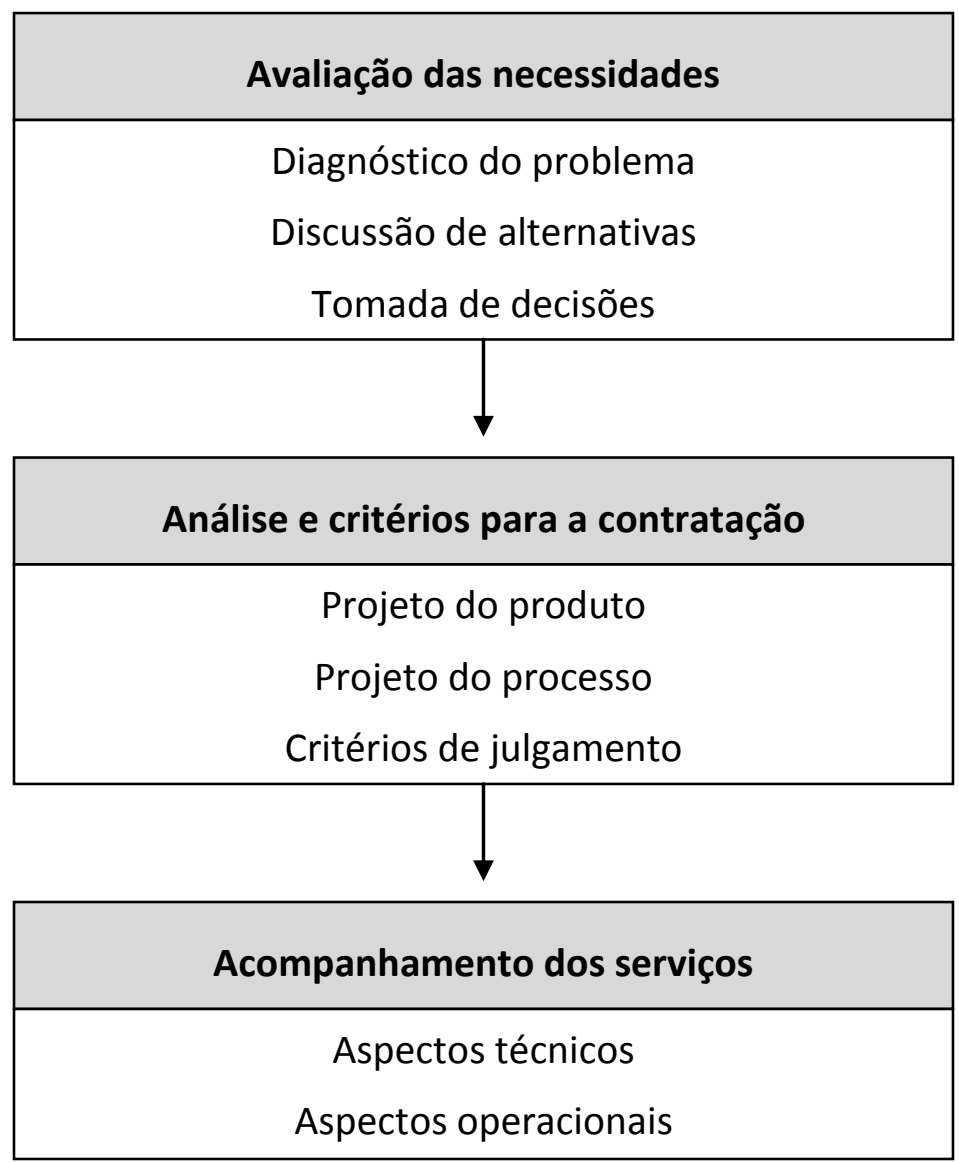

Figura 1 - Ações propostas para a gestão de obras de manutenção de fachadas.

\subsection{Objetivo do trabalho}

\section{O objetivo do trabalho é propor e validar um método $^{1}$ de gestão para o desenvolvimento de atividades de manutenção em revestimentos de fachadas, possibilitando um adequado desempenho técnico e operacional.}

Importante considerar que não faz parte do escopo deste trabalho o desenvolvimento de técnicas de racionalização, aqui entendidas como uma etapa seguinte ao gerenciamento (planejamento e controle). Entretanto, para o adequado

\footnotetext{
${ }^{1}$ Importante destacar a diferença entre os conceitos de método e metodologia. Como bem destaca
}

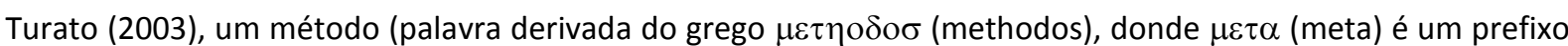

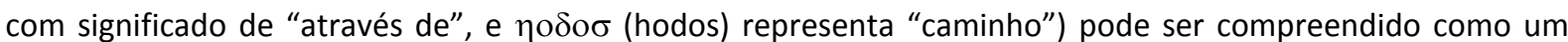
conjunto de regras elaboradas para se chegar a algo, ou o meio a partir do qual se pode chegar a algo, enquanto metodologia é o estudo dos métodos, ou a disciplina que se ocupa de estudar os métodos concebidos. 
acompanhamento da obra é imprescindível que as informações obtidas durante o controle sejam discutidas entre os agentes envolvidos dentro da maior brevidade possível permitindo a adequada retroalimentação do processo.

\subsection{Objeto e limitações do estudo}

O presente estudo se limita aos casos de edificações de múltiplos pavimentos sujeitas a intervenções de caráter preventivo ou corretivo nos seus revestimentos aderidos de fachada.

O foco principal do trabalho é a discussão de ações que possam ser utilizadas por profissionais de engenharia envolvidos na gestão dessas atividades, visando dar suporte aos agentes envolvidos (síndicos, ou administradores de condomínio, e as empresas construtoras).

As ações propostas tiveram o seu conteúdo avaliado a partir de uma validação interna realizada com especialistas, por meio da aplicação do Método Delphi ${ }^{2}$. Importante destacar que não faz parte do escopo do trabalho a análise da efetiva aplicação das propostas apresentadas, possível apenas por meio de uma validação externa, realizada com a aplicação das propostas em uma obra utilizando o conteúdo cientificamente aprovado pelos especialistas. Tal validação externa é proposta no final como uma continuidade do presente estudo.

\subsection{Estruturação do trabalho}

O texto apresentado no presente estudo está estruturado em três etapas: contextualização do estudo, proposição e discussão do método de gestão de obras de manutenção de fachada, e validação da proposição, conforme melhor ilustrado na Figura 2.

${ }^{2}$ Técnica de captura do conhecimento entre especialistas na busca progressiva de um consenso, utilizada para incremento da validade interna da pesquisa (Santos et al., 2005). Explicação detalhada do método apresentada no item 5.1. 


\section{Contextualização do estudo}

- Cap. 2 - Justificativas, pesquisas relacionadas com o tema, agentes envolvidos, conceitos de manutenção.

- Cap. 3 - Exposição de casos não orientados.

\section{Proposição e discussão do método proposto}

- Cap. 4 - Proposição inicial descritiva do método de gestão.

\section{Validação da proposta}

- Cap. 5 - Estudo de validação - conceitos e métodos.

- Cap. 6 - Análise da validação - Método Final Consolidado.

Figura 2 - Desenho explicativo da estruturação utilizada para o desenvolvimento do texto.

Para o desenvolvimento do referencial teórico do trabalho foram realizadas pesquisas bibliográficas a respeito do tema no Brasil e no exterior, com ênfase para teses e dissertações nacionais, e artigos publicados em periódicos e em eventos técnicos.

Em âmbito nacional são discutidos artigos publicados na Revista Ambiente Construído e nos eventos técnicos promovidos pela Antac (Entac, Sibragec e SBTA), e também textos técnicos desenvolvidos nos centros de pesquisa da Universidade de São Paulo, Universidade de Federal da Santa Catarina e Universidade Federal do Rio Grande do Sul. Além disso, buscou-se também o banco de dados disponível no Infohab e trabalhos diversos realizados em outros centros de pesquisa.

A revisão referente a trabalhos internacionais está baseada em pesquisas realizadas e publicadas a partir da década de 90 em periódicos técnicos como Construction and Building Materials, Construction Management and Economics, Cost Engineering, Facilities, Journal of Housing and the Built Environment, Journal of Management in Engineering, Structural Survey. 


\subsubsection{Contextualização do estudo}

O trabalho se inicia, no Capítulo 2, com uma discussão a respeito dos condicionantes que envolvem a execução de obras de manutenção em fachadas, contemplando dificuldades técnicas e operacionais, anseios e necessidades. Também são abordadas definições conceituais relativas à manutenção, essenciais para o desenvolvimento do trabalho, além de uma descrição pormenorizada dos agentes envolvidos numa obra de manutenção de fachada em condomínio.

O Capítulo 3 corresponde à fase exploratória do estudo, onde são relatadas experiências do autor em casos de obras dessa natureza, nas quais foram adotados, de forma não sistêmica, alguns dos tópicos que posteriormente serão avaliados no trabalho. Ao final do item é apresentada uma tabela prévia de fatores importantes de sucesso e insucesso constatados nas referidas obras. Essas obras tiveram suas atividades iniciadas em 2003 e concluídas entre os anos de 2004 e 2005, a depender do caso.

\subsubsection{Proposição do método}

A efetiva discussão e proposição do método é efetuada no Capítulo 4. Para facilitar a leitura e entendimento do texto, o capítulo já se inicia com a apresentação, de forma concisa, da proposta inicial da tese para gestão das obras de manutenção de fachada, desenvolvida com base nas considerações tratadas na fase inicial (etapa conceitual e fase exploratória) e no referencial teórico melhor discutido na seqüência do próprio capítulo.

A finalidade dessa fase do trabalho é reunir de forma ordenada a proposta inicial de gestão, cujos preceitos serão apresentados para validação e, apenas após os ajustes decorrentes dessa etapa, irão produzir um método de gestão cientificamente aprovado (apresentado no item 6.3) que permita ser entendido e aplicado de forma eficiente.

Para permitir que a proposta inicial fosse discutida e aprovada, os seus preceitos foram compilados em formato de questionamentos, a fim de serem enviados aos especialistas para obtenção das suas considerações durante a etapa de validação (Capítulo 5).

No Capítulo 4 são tratados os procedimentos técnicos indicados para o diagnóstico das necessidades da edificação, importante para a tomada de decisões quanto à escolha da 
alternativa de intervenção mais apropriada para o caso, em conformidade com os recursos disponíveis. Em seguida aborda-se a programação, o orçamento, e as questões que envolvem a contratação de empresas para realização dos serviços, tais como aspectos legais diversos (garantias, deveres e responsabilidades), critérios de julgamento, restrições etc.

Ainda dentro desse item são abordados aspectos relacionados ao acompanhamento das atividades ao longo da obra, divididos em controle tecnológico e controle operacional. No primeiro caso, são discutidos os elementos técnicos necessários para um adequado controle, envolvendo análise do projeto, materiais utilizados e procedimentos executivos. Já o controle operacional aborda questões como acompanhamento de medições e pagamentos, retenções fiscais, cumprimento de prazos, segurança (operários, moradores e transeuntes), entre outros.

\subsubsection{Validação da proposta}

A terceira etapa do trabalho (Capítulos 5 e 6) apresenta discussão da validação do método proposto. Para isso é necessário o levantamento de evidências de que as considerações apresentadas como propostas sejam técnica e cientificamente aceitas como verdadeiras e aplicáveis.

Existem algumas maneiras de se buscar comprovações que validem proposições de metodologias, que vão desde pesquisas com profissionais especialistas, até estudos de casos com aplicação e mensuração dos resultados. Na primeira situação está a validação interna de conteúdo, realizada por especialistas, escolhidos pelo pesquisador conforme critérios de seleção pré-determinados, que abalizam as proposições por meio de respostas a perguntas feitas por um questionário orientado, e a segunda pode ser denominada de validação externa, que se caracteriza pela análise da proposta já anteriormente discutida a partir da avaliação crítica de aplicações reais em campo.

Para o presente trabalho é utilizada a técnica de investigação das previsões dos especialistas empregada no Método Delphi com vistas à obtenção de uma avaliação consensual sobre as diretrizes do método proposto.

Esse método se aplica para a definição de um cenário a partir da expectativa de especialistas quanto ao comportamento futuro, sendo indicado quando se necessita 
validação interna ou aumento da validação externa da pesquisa (Santos et al., 2005). De forma análoga, o sucesso de uma intervenção numa edificação em uso vai depender do acerto quanto às previsões futuras de comportamento tanto dos seus componentes (aspectos técnicos) quanto das questões operacionais relacionadas com as atividades a serem executadas.

Os passos para a realização dessa validação estão a seguir descritos:

- Elaboração do questionário a partir do método de gestão proposto.

- Realização de avaliação prévia da eficiência do questionário por meio do seu envio a profissionais (total estimado de 20 pessoas) atuantes na área, conforme recomendado por Cardoso et al. (2005) e Costa (2001).

- Avaliação das respostas obtidas na etapa de teste do questionário para a realização de eventuais ajustes.

- Levantamento de nomes de pesquisadores especialistas com atuação nas áreas contempladas no trabalho, realizado a partir de artigos publicados em eventos e revistas técnicas nacionais e internacionais relacionadas ao tema;

- Definição de critérios de inclusão desses especialistas.

- Elaboração de um painel eletrônico (web site) disponível na internet, no qual os especialistas têm acesso às informações relacionadas com a pesquisa e podem responder ao questionário a partir de uma senha individual de acesso.

- Tratamento estatístico dos dados obtidos na primeira rodada de respostas.

- Solicitação aos especialistas de uma nova rodada das questões para reavaliação das respostas com base na sua posição estatística em relação ao grupo.

- Realização de novo tratamento estatístico para avaliar a evolução consensual dos aspectos diversos abordados na proposta, podendo-se efetuar novas rodadas de questionamentos até que se julgue necessário.

Essa metodologia de validação é aplicada de forma consagrada em diversos ramos da ciência aplicada, especialmente nas áreas de ciências sociais e da saúde, com grande aceitação no meio técnico e acadêmico. 
Como elemento auxiliar na consolidação do trabalho, ao final é apresentado também estudo de caso em obra de manutenção de fachada onde as propostas foram implantadas de forma ordenada. Esse estudo não pode ser classificado como uma validação externa, uma vez que aconteceu simultaneamente à validação interna, de modo que a proposta final contemplando as contribuições discutidas pelos especialistas não foi aplicada e avaliada de forma integral.

A principal contribuição desse estudo de caso é a análise da aplicabilidade das ações propostas em uma situação prática, e servirá como um complemento às opiniões dos especialistas. Assim, foi escolhida uma obra cujas atividades de planejamento e controle foram acompanhadas profissionalmente pelo autor ${ }^{3}$ durante 15 meses e efetuadas com base no método apresentado nessa pesquisa, amparada também nos erros e acertos avaliados nos casos anteriores, discutidos na fase exploratória do trabalho (Capítulo 3).

Ao final (Capítulo 7) são apresentadas as conclusões do estudo, onde se discutem as dificuldades para realização de cada uma das etapas descritas, e principalmente as conclusões quanto à metodologia efetivamente considerada como validada cientificamente.

${ }^{3}$ Trabalho técnico realizado pela empresa TECOMAT LTDA. (Tecnologia da Construção e Materiais Ltda.) e edificação situada na cidade de Recife - Pernambuco. 


\section{CONSIDERAÇÕES SOBRE O TEMA E ABORDAGEM CONCEITUAL}

\subsection{Justificativas para o desenvolvimento da pesquisa}

Os benefícios obtidos pela execução de obras de construção civil estão, na maioria das situações, atrelados a transtornos diversos para os envolvidos ("desculpem o incômodo estamos trabalhando para melhorar a sua cidade", "evite estacionar próximo da obra - há risco de queda de materiais").

Esses transtornos se tornam ainda mais intensos no caso de obras realizadas em edificações já concluídas, e agravados se as atividades forem realizadas nos seus revestimentos externos de fachada, onde questões de ordem técnica e operacional são imprescindíveis para que seja garantido o sucesso do empreendimento. Surgem de imediato algumas perguntas:

\section{Existem muitos problemas em revestimentos de fachada? Qual a razão?}

A queda de revestimentos verticais aplicados em fachadas, e mesmo em áreas internas, pode causar sérios problemas materiais e pessoais. Apenas para citar alguns exemplos, em janeiro de 2006 um a parte do revestimento em argamassa caído de uma fachada amassou o teto do carro, estilhaçou o pára brisas e se acomodou sobre o banco do carona de uma pessoa que manobrava seu automóvel no Rio de Janeiro, o que causou também ferimentos em outros transeuntes que passeavam pela rua no momento do acidente $^{4}$

Outro caso noticiado ocorreu em maio de 2005 num hospital público no Rio de Janeiro, quando uma parte do emboço soltou-se do teto e caiu, ferindo 17 pessoas no ambulatório ${ }^{5}$. Ainda no Rio de Janeiro, em novembro de 2005, um carro foi atingido devido à queda de parte do revestimento de fachada do 11 ㅇadar de um prédio situado no centro da

\footnotetext{
4 Informação disponível em: <http://www.noticias.terra.com.br >. Motorista sai ilesa após reboco atingir o seu carro. Acesso em: 05 mar. 2006.

5 Informação disponível em: <http://www.estadao.com.br/ultimas/cidades/noticias>. Chuvas causam estrago também no Rio de Janeiro. Acesso em: 30 out. 2006.
} 
cidade. Os transtornos foram grandes, a ponto da vítima chamar a polícia quando informado pelo síndico que não haveria ressarcimento pelo prejuízo ${ }^{6}$.

Yiu et al. (2002) relatam também a ocorrência acidentes responsáveis por danos e até mortes de pedestres na cidade de Hong Kong decorrentes da queda de materiais de prédios antigos altos em concreto armado.

Além desses casos noticiados na imprensa, vários artigos e trabalhos científicos são constantemente apresentados relatando estudos de casos de descolamento e queda de revestimentos aderidos de fachada, tais como Costa e Silva (2001), Campante (2001), Mansur et al. (2006), entre outros.

Grilo e Calmon (2000), em pesquisa realizada em 100 edificações multi familiares na cidade de Vitória-ES, encontraram elevado percentual de casos de descolamento de placas cerâmicas de fachada dentre as unidades avaliadas, com ênfase para os altos valores observados já nos primeiros anos de uso (0-5 anos: 9\% - 5-10 anos: 34,5\% - 10-20 anos: $14,4 \%$ - >20 anos: 17,6\%).

Os acidentes ocorridos em elementos diversos de fachada, incluídos ainda quedas de marquises, elementos decorativos, entre outros, têm causado preocupação junto aos órgãos competentes das grandes cidades. A exemplo do que ocorre também em diversas cidades e países pelo mundo, como Buenos Aires (Argentina), Madri (Espanha), Grã Bretanha, Chicago e Nova lorque (Estados Unidos), a Lei Ordinária no 6.323 (Porto Alegre, 1988) define regras a respeito da manutenção e conservação dos elementos construtivos em fachadas, em especial as marquises.

Em Pernambuco, a Lei no 13.032 (Pernambuco, 2006) obriga a realização de vistorias periciais e manutenções periódicas de todos os aspectos afetos à solidez e segurança da edificação, contemplando elementos estruturais (fundação, pilares), instalações prediais e fachadas. Tais vistorias devem ser realizadas em períodos de 3 anos por profissional de engenharia (ou empresa) com habilitação específica atestada pelo CREA para operação, uso e manutenção.

\footnotetext{
6 Informação disponível em: <http://www.odia.terra.com.br/rio>. Carro de empresário é atingido por reboco no centro. Acesso em: 24 abr. 2006.
} 
A esse propósito, como abordam Flores e Brito (2001), citados por Resende (2003), é importante destacar que essas leis devem ter um caráter incentivador para a realização de atividades de manutenção, por meio de descontos em impostos, por exemplo, e não apenas meramente punitivo, ao contrário do que acontece em alguns casos.

Os problemas ocorridos em fachadas, a despeito do risco quanto à segurança, demandam alto custo para recomposição por conta da necessidade de equipamentos especiais de apoio $^{7}$, telas de proteção, mão-de-obra especializada (e mais cara), dependência das condições ambientais locais (intempéries, ventilação), além do desconforto estético e desvalorização comercial do imóvel.

Como bem aborda Resende (2004), deve-se destacar a importância da fachada para o edifício como uma fronteira entre os ambientes externo e interno, e cuja exposição aos agentes de degradação são bastante intensos.

As origens ${ }^{8}$ para a ocorrência dos problemas de descolamentos, em linhas gerais, podem ser devidas à inadequação dos materiais empregados, a deficiências ocorridas durante a etapa de produção, a falhas ou inexistência de manutenção durante o uso, ou por conta de movimentações da base sobre a qual o revestimento está assentado, cujas magnitudes devem ser previstas durante a etapa de projeto.

${ }^{7}$ Os equipamentos de apoio para os operários trabalharem em fachadas recebem denominações diversas a depender da região do país: balancim, balança, andaime suspenso, jaú. Para efeito da presente pesquisa será adotado o termo balancim, no singular, e balancins, no plural.

${ }^{8}$ Importante aqui destacar algumas diferenças conceituais. Como enfatiza Aranha (1994), a causa de uma patologia pode ser entendida como o procedimento inadequado, adotado durante o processo construtivo, que provocou alteração no desempenho esperado de um elemento ou componente da edificação. Esse conceito está em conformidade com a terminologia adotada pelo W86 (CIB, 1993), apesar dessa definição não se apresentar descrita no seu apêndice $F$, onde estão relatados os principais termos empregados no estudo de patologias. Entendidas as causas para o surgimento do problema, é importante se determinar as suas origens, o que pode ser difícil em algumas situações. Quando, por exemplo, o descolamento do revestimento cerâmico ocorre na camada de argamassa colante, a origem dessa deficiência pode ser atribuída à produção, por conta de falhas de aplicação do operário (devido à abertura de panos de argamassa muito extensos), ou ao próprio material, em decorrência da sua capacidade de aderência insuficiente. 
Estudos de caso apresentados pelo autor da presente pesquisa em sua dissertação de mestrado (Costa e Silva, 2001) a respeito do descolamento de revestimentos cerâmicos de fachada, por exemplo, apontam como principais causas para o problema a ausência de juntas de movimentação (projeto), deficiências na capacidade resistente da argamassa adesiva (materiais) e falhas de preenchimento do tardoz da placa cerâmica com a argamassa (produção).

\section{O crescimento das cidades contribui para a ocorrência dos problemas?}

O grande êxodo rural ocorrido historicamente no Brasil desde o início do século passado, bem como o avanço demográfico da população a partir do mesmo período, tem levado a uma aglomeração cada vez maior de pessoas nas capitais, tornando-as bastante populosas. Mas como acomodar essa massa crescente de pessoas nas cidades?

Uma das alternativas é a expansão territorial dos centros mais desenvolvidos, nos quais ocorre uma aglomeração de municípios vizinhos transformando as cidades em grandes regiões metropolitanas, o que obriga a transferência das pessoas para as áreas periféricas, geralmente distantes das suas fontes principais de renda.

Outra opção é a expansão vertical das cidades, freqüentemente destinada à camada da população melhor assistida, classes média e alta, com potencial aquisitivo para residir próximo ao seu local de trabalho e também dos principais centros de entretenimento da cidade.

Os edifícios de múltiplos pavimentos representam a expressão mais clara de expansão vertical, podendo ser destinados a diversas finalidades, tais como residência, comércio (escritórios, shopping center), lazer (salas de cinema, galerias de arte), utilidades públicas (garagem de automóveis, repartições).

Como descrevem Veríssimo e Bittar (1999), já a partir do final dos anos 20, motivado pela possibilidade de reverter em renda as grandes áreas territoriais que dispunham os tradicionais donos das terras, alguns deles endividados, foram criados os primeiros "arranhacéus" (assim conhecidos na época os prédios com 20 ou mais pavimentos), especialmente nas cidades de São Paulo e Rio de Janeiro. A construção vertical ganhou maior impulso no final da década de 40, após a Segunda Guerra, com a execução dos conjuntos habitacionais destinados às camadas mais pobres, consolidando-se nas décadas seguintes (anos 60 - 
incentivo à compra das casas próprias por meio de financiamentos, criação do BNH; anos 80 - explosão dos condomínios de luxo com privacidade e segurança) e persistindo até os dias atuais.

No entanto, a preocupação com o desempenho dessas edificações em longo prazo era incipiente naquela época, quando as características do concreto armado, por exemplo, eram baseadas essencialmente no atendimento às exigências mecânicas.

Com o passar dos anos as estruturas começaram a apresentar sinais de problemas cujas soluções exigiam desenvolvimento técnico e operacional para a sua solução, passandose então a estudar as causas para a ocorrência desses problemas, as respectivas ações preventivas (tanto na etapa de projeto quanto após a execução) e também terapêuticas (ISAIA, 2005).

De acordo com a experiência do autor, as manifestações patológicas comumente mais encontradas no Brasil em edifícios reticulados em concreto armado de múltiplos pavimentos são a corrosão da armadura, cujas conseqüências estruturais podem ser muito graves, infiltrações de água, de origens diversas, e descolamentos em revestimentos aderidos, principalmente nas áreas externas.

\section{A evolução tecnológica está contribuindo para a redução dos problemas?}

É evidente que o maior conhecimento a respeito das características dos materiais utilizados na construção e a natural evolução na execução das obras levam a um amadurecimento e redução na ocorrência de problemas.

Entretanto, a evolução do conhecimento e tecnologia envolvidos na construção civil tem possibilitado aos construtores utilizarem elementos estruturais cada vez mais esbeltos e arrojados, com crescentes níveis de deslocamentos e de solicitações, motivados pela possibilidade de obtenção de maiores vãos e custos mais baixos de fôrmas e mão-de-obra.

Pesquisa realizada por Fonte et al. (2005) aponta a tendência de crescimento, a partir da década de 70 , do número de pavimentos e também dos seus respectivos índices de esbeltez (relação entre altura e largura) nos edifícios residenciais no Brasil. Dentre os dados levantados, em outros países o maior índice de esbeltez encontrado foi de 9,8 (Petronas Tower, na Malásia), enquanto no Brasil podem-se encontrar valores com índice 10 (Garagem San Siro, em São Paulo) e até 14,4, em Recife. Ainda nesse trabalho, observa-se até uma 
tendência de redução do índice de esbeltez dos prédios pesquisados conforme aumenta o número de pavimentos, o que é positivo para a estabilização frente aos esforços de vento.

A possibilidade de adoção desses parâmetros é decorrente da evolução ocorrida nas ferramentas de cálculo disponíveis para avaliação das cargas atuantes e suas implicações na estrutura, e também da evolução no conhecimento do comportamento dos materiais componentes, dos elementos estruturais, e do seu desempenho ao longo do tempo.

Em virtude dessa evolução nas ferramentas de cálculo existem diversos modelos de cálculo (lajes isoladas, pórtico planos bidimensionais, elementos finitos e pórticos espaciais tridimensionais etc.) utilizados pelos projetistas de estruturas, cada qual com suas peculiaridades relacionadas com a abrangência de informações, restrição e facilidade de uso, nível de precisão (Silva et al., 2003).

Porém, apesar das estruturas estarem menos robustas e mais arrojadas, esteticamente favorecidas, e com grande economia de área perdida, esses maiores níveis de deslocamento das estruturas têm ocasionado problemas devido às solicitações impostas, especialmente observados nos revestimentos.

Andolfato; Camacho e Maurício (2003) salientam que, em virtude da evolução tecnológica e da confiabilidade dos materiais, há necessidade de maior compreensão por parte dos projetistas estruturais quanto ao comportamento dos edifícios, principalmente quanto aos efeitos de segunda ordem (relacionados com a ação do vento e seus deslocamentos em edifícios altos). Ainda segundo esses autores, a análise de edifícios de múltiplos pavimentos contemplando os esforços de segunda ordem, que originalmente levava a deslocamentos horizontais relativamente baixos, com o aumento da esbeltez dos edifícios passou a resultar em valores mais significativos.

Trabalho apresentado por Guarda e Lima (2003) também enfatiza a ocorrência de deslocamentos excessivos em decorrência da maior flexibilidade dos pavimentos, e apresenta a evolução pertinente ao tema das diretrizes normativas da NBR 6118 (ABNT, 2003), atualizada após mais de 20 anos em uso, comparando ainda com normas

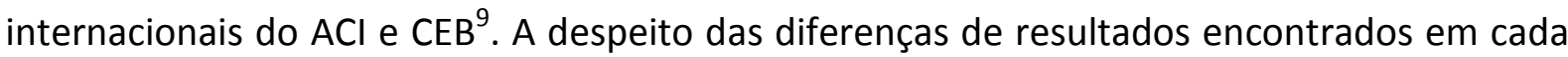

\footnotetext{
${ }^{9} \mathrm{ACl}$ - American Concrete Institute; CEB - Comitée Euro International du Béton.
} 
caso, é ressaltada no trabalho a necessidade de atenção dos projetistas quanto à análise dos deslocamentos, sejam imediatos ou diferidos, que ocorrem, respectivamente, logo após a aplicação das cargas e ao longo dos anos.

Em edifícios de múltiplos pavimentos, diversos pesquisadores vêm estudando outros aspectos de influência nos níveis de deslocamento, em especial a interação entre o solo e a estrutura. Nesses casos, a análise integrada possibilita uma avaliação mais precisa dos recalques previstos e a redistribuição dos esforços ao longo da estrutura (ANTUNES e IWAMOTO (2000)). Fonte e Fonte (2003) apresentaram trabalho em que salientam a necessidade de se buscar sistemas estruturais cujos esforços transferidos para os elementos de fundação proporcionem uma maior uniformização dos recalques, problema crítico especialmente nas fundações diretas.

Já Holanda Jr et al. (2000) apresentaram estudo contemplando o efeito incremental construtivo associado ao comportamento do solo no deslocamento previsto para as estruturas, e apontam a importância da análise da aplicação gradual do carregamento para a avaliação estrutural. Esse estudo alerta para a necessidade de atendimento aos prazos para execução das alvenarias e dos revestimentos aplicados sobre bases de suporte em fase acentuada de acomodação durante a realização da obra. A questão da velocidade da construção associada aos prazos de execução do revestimento é também abordada por Sabbatini (1998) e Casimir (1994).

Também as características arquitetônicas com grandes superfícies lisas e menor quantidade de detalhes decorativos, responsáveis por pontos de desvio no fluxo contínuo da água de chuva ou outros agentes agressivos na fachada, aliadas à construção de edifícios com grandes alturas, contribuem para uma maior necessidade de manutenção nesses componentes (PEREZ, 1988).

Por conta de todos esses aspectos, pode-se constatar que não se pode tratar o revestimento em separado do edifício (CASIMIR, 1994). Como bem destaca Lichtenstein (1985), o comportamento do edifício é o resultado do comportamento das suas partes, da interação destas partes entre si, e da interação do edifício com o entorno. 
Os deslocamentos ocorridos na base apresentam um reflexo imediato nos elementos que neles estão apoiados. Os revestimentos aderidos ${ }^{10}$, cuja fixação à base se dá por meio de argamassa com ancoragem físico-química, caso apresentem problemas podem levar grande risco aos usuários da edificação, ou mesmo aos transeuntes, uma vez que as falhas no seu desempenho, em geral, provocam o descolamento e conseqüente queda do material de grandes alturas.

\section{Não existe uma cultura de manutenção?}

A existência de vários interesses, representados pelos proprietários das diversas unidades, utilizando áreas comuns a todos, torna a administração condominial uma atividade árdua, especialmente agravada quando se trata de intervenções de manutenção do imóvel, muitas vezes relegada a segundo plano em favor de outras necessidades cujos benefícios são mais imediatos (por exemplo, a compra de equipamentos para ginástica, a montagem de "play ground", a aquisição de central de segurança etc.).

Conforme salientado por Casimir (1994), os proprietários normalmente são pouco sensíveis às necessidades das manutenções ${ }^{11}$ nas suas edificações. Por outro lado, alterações estéticas e funcionais são justificativas com maior nível de aceitação. Essa dificuldade em se definir o tipo de intervenção a ser realizada no imóvel é aumentada pelo fato de se tratarem de áreas comuns pertencentes a vários donos, o que causa também transtornos para a atividade de gerenciamento (Yiu et al., 2002).

O mercado de firmas especializadas que executam serviços de manutenção em edificações habitadas é composto, em geral, por empresas de pequeno e médio porte. A inexistência de maiores níveis de exigência por parte do proprietário (contratante), motivado, muitas vezes, pela falta de conhecimento específico, contribui para o surgimento de empresas com pouca qualificação técnica (Gehbauer, 2004). Considerando a grande quantidade de obstáculos técnicos e operacionais a serem transpostos nesse tipo de serviço,

\footnotetext{
${ }^{10}$ Segundo Maranhão et al. (2003) entende-se por revestimento aderido aquele assentado sobre uma
} base de suporte por meio de argamassa ou pasta, ficando aderido à mesma de forma permanente.

${ }^{11}$ Os conceitos de manutenção estão discutidos no item 2.3 - Manutenção - conceituação. 
que exigem experiência e qualificação dos envolvidos na execução das atividades, isso chega a ser um contra-senso.

$\mathrm{Na}$ busca por qualidade, a indústria da construção civil sempre evidenciou abordagens mais efetivas nas etapas de projeto e execução, entretanto há um consenso no meio técnico da necessidade de analisar o desempenho da edificação também após a sua conclusão (NBR 14.037, ABNT (1998)).

Instrumentos eficientes para melhorar a comunicação entre essas fases são as avaliações pós-ocupacionais (APO) e os manuais de operação, uso e manutenção, documentação técnica produzida para esclarecer as dúvidas dos usuários após a entrega do imóvel. A utilização correta por parte dos envolvidos desses instrumentos pode retornar às etapas de projeto e execução informações essenciais para o desenvolvimento de melhores produtos.

Conforme observado há 20 anos por Perez (1988), e que ainda é uma realidade atual, em função da falta de cultura de manutenção por parte de alguns engenheiros e arquitetos, que não têm o costume revisar criticamente os seus projetos depois que as edificações são colocadas em uso, o ônus da constatação e convívio com as eventuais deficiências fica a cargo dos usuários. Isso dificulta a retroalimentação necessária para que se reduzam as necessidades de intervenção, ou que permitam a sua execução de forma mais eficiente.

Como salientam Taborda e Soeiro (1994), as manifestações patológicas ocorridas após a construção podem ser oriundas de fenômenos relativamente conhecidos, de modo que é possível conceber, construir e projetar estratégias (planos) de manutenção capazes de resistir a tais efeitos, ou ao menos minimizá-los. Essa lógica carece, porém, da prática na existência de atividades de manutenção.

Esse raciocínio é também compartilhado por Dorfman e Petrucci (1989), que destacam o projeto como um instrumento para a prevenção de problemas e para o desenvolvimento de mecanismos que sirvam para facilitar as atividades de manutenção, a partir da interpretação do conhecimento prévio das características da edificação e da atuação do meio.

No capítulo sobre patologia das construções, escrito pelo autor desta Tese e pelo Engo Tibério Andrade e apresentado em recente livro de concreto publicado pelo Ibracon 
(ISAIA, 2005), foi abordado o problema da deficiência das atividades de manutenção citando a importância da quebra do paradigma de conservadorismo da indústria da construção civil e destacando uma matriz de responsabilidades dos agentes envolvidos, composta por projetistas, executantes, usuários e até o poder público.

No Reino Unido, segundo o BRE (2001), os contratos de seguros dos prédios são avaliados de acordo com as ações e previsões de manutenção efetuadas pelos condomínios, o que denota a importância dada a essa atividade para a conservação dos edifícios e seus componentes.

A NBR 5.674 (ABNT, 1999), que trata de manutenção de edificações, apresenta ainda uma abordagem crítica econômica e ambiental relacionada com a cultura do edifício "descartável", passível de simples substituição após o término das suas condições de uso, e cujos custos sociais não são contabilizados, mas refletem na qualidade de vida dos usuários.

No caso específico dos revestimentos cerâmicos, abordagem interessante é apresentada por Casimir (1994), quando o autor questiona se é uma visão pessimista ou realista admitir que um elemento aderido à superfície de uma edificação, sujeito a todo tipo de solicitações, irá apresentar falhas no futuro, mesmo que no momento inicial esteja "seguro".

Pesquisa desenvolvida por Meira e Heineck (2002) aponta também a influência dos condicionantes sócio econômicos dos usuários com a realização e satisfação das atividades de manutenção realizadas nas suas edificações, tais como idade, grau de instrução, forma de ocupação (proprietário ou inquilino), localização (bairro) e sua relação com a vizinhança. Dentre as suas conclusões, destaca-se a maior preocupação com a manutenção por parte dos proprietários dos imóveis com faixa etária dos 30 aos 60 anos, com ênfase para priorização das áreas externas para os chefes de família com menor grau de instrução, e das áreas internas para aqueles com nível superior de escolaridade.

Grilo e Calmon (2000) também apresentam pesquisa de satisfação junto a usuários realizada em 100 edificações na qual, entre outros aspectos, foram observados níveis de insatisfação maiores dos usuários com os edifícios, em comparação com as suas unidades privativas, em todas as faixas avaliadas. A diferença vai acentuando com a idade do imóvel, pela falta da freqüência de manutenção. 
Tal comportamento do usuário pode refletir um pouco o seu desconforto em explicitar as deficiências encontradas na sua casa, mas pode também indicar uma predisposição mais acentuada em solucionar problemas comuns (em fachadas, por exemplo), quando os custos são divididos.

\section{Quais as principais dificuldades para a realização das atividades de manutenção em} fachadas?

Conforme anteriormente comentado, todo tipo de obra em que a edificação se encontra em uso apresenta uma série de dificuldades de diversas ordens, especialmente aquelas obras executadas em áreas de fachada, complicadas por sua natureza.

Com bem salientam Attalla e Hegazy (2003), as obras de manutenção são únicas e desafiadoras, pois apresentam grande dificuldade de previsão de tempo, custo e qualidade, e tal quadro se torna ainda mais complexo com a edificação em uso, exigindo discussão de aspectos diversos como áreas de acesso, proteção, segurança e planejamento de equipes de trabalho para cada etapa dos serviços.

Barrientos e Qualharini (2004) destacam que a execução de obras em edificações em uso, sem transferência dos usuários, pode causar diversos incômodos, tais como a necessidade de adequação dos horários atrelados aos hábitos dos usuários, dificuldades para definição dos horários de início e fim dos serviços, no seu dia a dia, e até mesmo problemas de roubo ou outros infortúnios dessa natureza.

Aos casos das edificações habitadas devem ser somados ainda problemas como ruídos, sujeira, redução da funcionalidade do prédio (por exemplo, interdição da piscina situada sob a fachada, durante a execução da obra), desconforto estético, dificuldades para instalação dos balancins no pavimento de cobertura (quando não concebida para isso). Essa discussão está apresentada também no BRE (2001), salientando os problemas de acesso seguro à fachada e os distúrbios diversos causados aos usuários.

Sanvido e Riggs (1993) elencam as informações deficientes e as limitações físicas e operacionais como as principais restrições para o desenvolvimento de atividades de gerenciamento de projetos em edificações em uso.

Abordagem interessante apresentada por Yiu et al. (2002) indica que as obras corretivas de manutenção são, em geral, de prazo curto e definitivas, de modo que não 
existe a idéia de "fidelização" do cliente, a menos que seja para atividades preventivas, de menor porte. Com isso, não há a busca pela parceria direta com o cliente, mas apenas a preocupação com o desenvolvimento de um bom trabalho que possa servir como uma indicação de capacitação.

No caso das fachadas, é preciso que sejam especificadas soluções técnicas "duráveis", que evitem a falência prematura desse subsistema, e que sejam adotadas alternativas que privilegiem as atividades de manutenção preventiva ao longo da utilização da edificação. É importante destacar que, na grande maioria dos sistemas de revestimento adotados em fachadas, a vida útil dos seus elementos constituintes é inferior à vida útil da edificação, o que implica na necessidade imperativa de intervenções na fachada do prédio ao longo da sua existência.

Em artigo apresentado por Grilo e Calmon (2000) é comentada a importância de se associar a vida útil de cada componente da edificação, a complexidade envolvida na sua manutenção e a sua responsabilidade estrutural, com a vida útil da própria edificação.

Observa-se a necessidade de discussão e massificação do conceito de manutenibilidade, que retrata a maior ou menor facilidade de se executar numa edificação a atividade de manutenção (PEREZ, 1988). É intuitivo imaginar que tal facilidade pode ser obtida de forma mais eficiente caso as ações sejam previstas já na etapa de projeto, especialmente no caso dos serviços executados em fachadas.

No tocante à segurança, para obras em fachada deve-se ressaltar a necessidade imperativa de garantia da integridade de funcionários da obra e do próprio condomínio, dos moradores e dos transeuntes, o que pode levar a condução desse serviço a uma atividade de risco para os envolvidos.

Quais os anseios dos proprietários do imóvel quando da execução de uma obra de manutenção da fachada?

Os principais anseios que os condôminos, ou proprietários dos imóveis, possuem quando da realização das atividades de manutenção são:

- Garantia de que a solução técnica indicada seja eficaz no sentido de resolver o problema existente (manutenção corretiva) ou se antecipar à sua ocorrência (manutenção preventiva). 
- Garantia do cumprimento do prazo de execução dos serviços dentro do limite estabelecido antes do seu início (considerando esse prazo como o menor possível, dentro das circunstâncias técnicas e operacionais da obra).

- Garantia de que o novo serviço seja executado tecnicamente de forma correta, em total conformidade com a boa prática construtiva (normalização, procedimentos executivos), sem ocorrência de problemas diversos operacionais.

Naturalmente essas exigências devem ser pautadas a partir da necessidade de intervenção prevista para o prédio e em conformidade com a disponibilidade de recursos do condomínio.

\section{Como é possível solucionar esses problemas?}

Ao longo dos anos, os agentes envolvidos no processo produtivo da construção civil têm-se esforçado para a garantia de serviços e produtos eficientes, que se refletem tanto em ações de caráter técnico como operacional. Esses esforços são fruto de uma exigência de mercado, não apenas por parte dos usuários ou proprietários, mas também devido à necessidade de redução de custos.

As atividades de gerenciamento, entendidas como ações que vão desde a concepção até a entrega final da obra, passando pela programação, orçamento, acompanhamento tecnológico, têm sido incorporadas como apoio para o desenvolvimento dos mais diversos empreendimentos.

Como bem salientam Sanvido e Riggs (1993) o gerenciamento adequado e o emprego de métodos eficientes de ação são instrumentos importantes para que sejam atenuados os problemas em atividades de manutenção, obtendo-se redução de custos e prazos.

A gestão de uma atividade construtiva pode-se tornar mais complicada quando envolve sujeitos (proprietários) não habilitados, como acontece no caso de obras em edificações já concluídas. A falta de conhecimento técnico específico e conseqüente insegurança quanto aos serviços efetuados, e os já comentados "traumas" operacionais, são alguns exemplos de elementos complicadores existentes durante o desenrolar desse tipo de atividade. 
A Figura 3 apresenta esquema de ações proposto nesta Tese para a gestão das atividades de manutenção dos revestimentos de fachada, cujos conceitos e detalhes serão desenvolvidos ao longo do trabalho.

Em analogia ao descrito por Vieira Netto (1988), os macro objetivos do gerenciamento de uma atividade de recuperação em fachadas devem ser assegurar o cumprimento das metas estabelecidas, otimização do desempenho técnico e de produção, e compatibilização com os custos.

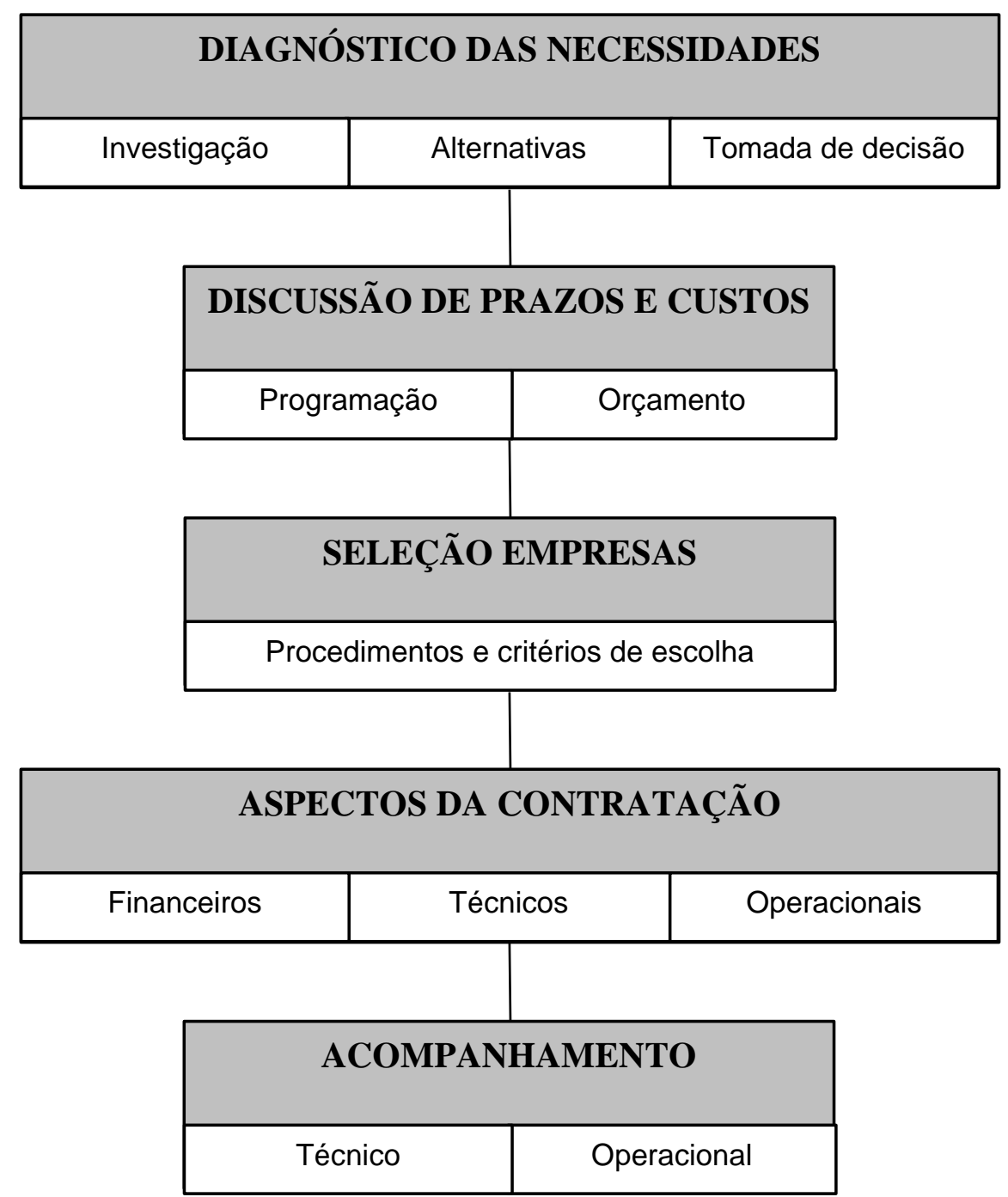

Figura 3 - Descrição das ações básicas para gestão das atividades de manutenção em revestimentos de fachada. 
Abordagem interessante apresentada por Attalla e Hegazy (2003) descreve a avaliação da eficiência da atividade de gestão em obras de manutenção a partir do cálculo do Fator de Desempenho (Cost Performance Factor - CPF), representado pela Expressão 1:

$$
\mathrm{CPF}=1-\left(\begin{array}{c}
\text { alteração nos custos iniciais } \\
\text { da intervenção } \\
\text { custos iniciais da intervenção }
\end{array}\right) \times 100 \text { (Expressão 1) }
$$

Com base nessa fórmula, quanto menos alterações de custos ocorreram na obra, maior o fator e melhor a eficiência das atividades de gerenciamento, isto é, menores foram as necessidades de intervenção no projeto e nas previsões iniciais. Na conclusão do seu trabalho, a partir de dados coletados em pesquisa efetuada com 40 projetos, são apresentados os principais fatores de sucesso para a gestão da manutenção de projetos de manutenção (Tabela 1).

Tabela 1 - Relação de fatores de sucesso para a implementação da gestão de obra de manutenção (adaptado de Attalla; Hegazy, 2003).

\begin{tabular}{|c|c|}
\hline Estágios da obra & Fatores principais de sucesso \\
\hline $\begin{array}{l}\text { Concepção - definição do escopo e } \\
\text { planejamento }\end{array}$ & $\begin{array}{l}\text { Discussões de projetos precedentes. } \\
\text { Definição de planilha orçamentária. } \\
\text { Criação de “comitês" de projeto. }\end{array}$ \\
\hline Contratação & $\begin{array}{l}\text { Qualidade de especificação e padronização (com participação da } \\
\text { equipe de operação e uso). } \\
\text { Pré-qualificação das empresas concorrentes. } \\
\text { Definição de preços unitários. }\end{array}$ \\
\hline Programação & $\begin{array}{l}\text { Coordenação de programação. } \\
\text { Acompanhamento com gráfico de barras. } \\
\text { Método do caminho crítico. }\end{array}$ \\
\hline Custos & $\begin{array}{l}\text { Acompanhamento da variação dos custos. } \\
\text { Análise do fluxo de caixa. }\end{array}$ \\
\hline Qualidade & $\begin{array}{l}\text { Comprometimento expresso com a qualidade. } \\
\text { Controle da obra realizado por empresas independentes. } \\
\text { Irrestrito cumprimento às especificações. }\end{array}$ \\
\hline Comunicação & $\begin{array}{l}\text { Reuniões periódicas. } \\
\text { Mecanismo de respostas rápidas. }\end{array}$ \\
\hline Segurança & $\begin{array}{l}\text { Comitê de saúde e segurança. } \\
\text { Inspeção pela equipe de operação e manutenção. }\end{array}$ \\
\hline
\end{tabular}


Além disso, deve-se entender que as atividades de gerenciamento devem ser de fácil controle, criadas a partir metas mensuráveis e possíveis de serem alcançadas.

Desse modo, o que propõe o presente trabalho é que os problemas em fachadas podem ser melhor conduzidos a partir de uma gestão profissional da atividade de manutenção, cujos passos estão descritos na Figura 3. Utilizando conceito defendido por Gomide (2006), trata-se de uma gestão técnica do condomínio. 


\subsection{Pesquisas relacionadas com o tema}

As pesquisas relacionadas aos temas de planejamento e organização de obras, num conceito mais geral, vêm progredindo de forma gradativa no Brasil, obedecendo a uma tendência observada em todo o mundo.

Essa afirmação é confirmada na pesquisa realizada por Van Vliet (2003) em artigos publicados no Journal of Housing and Built Environment (JHBE) durante os anos de 1996 a 1999, que discute a evolução de estudos sobre gerenciamento e planejamento de obras nesse período, representada pelo crescimento no número de artigos e livros técnicos publicados nesse periódico.

Tal evolução é oriunda dos maiores níveis de exigência decorrentes de uma competitividade cada vez mais acirrada, além do estabelecimento dos preços de venda pelo mercado consumidor, o que reduz as margens de lucro das empresas produtoras de bens ou serviços. Esse comportamento já é realidade há mais tempo na indústria seriada, vem tomando corpo também na construção de edifícios e, por conseqüência, nas obras de manutenção.

Discussão sobre as melhores práticas para intervenção em edificação em uso foi apresentada por Attalla e Hegazy (2003) em trabalho que aborda recomendações gerais e estudo de caso com as etapas de gerenciamento de obra de reconstrução de escola na cidade de Ontário, Canadá, cujos principais tópicos são abordados ao longo do presente trabalho.

Já Zelouf (1992) discute as possibilidades de análise para intervenção em edificações públicas nos Estados Unidos, contemplando as alternativas (demolição e reconstrução, reabilitação ou alteração parcial) e até proposições matemáticas auxiliares para avaliação. São levados em conta os transtornos causados durante a intervenção, a origem dos recursos, as necessidades da comunidade local e até o seu impacto urbano.

Interessante nos casos de obras de manutenção em edificações, e em especial para as fachadas, é que são trabalhos cuja complexidade de fatores envolvidos acaba gerando dificuldades e problemas de difícil previsão. Por conta disso, e também da natural dificuldade das pessoas em aceitar e discutir problemas cujas causas the possam ser atribuídas, não são comuns na literatura relatos precisos de casos e, principalmente, 
problemas ocorridos na prática. Outro agente complicador é que, em geral, artigos dessa natureza são oriundos de profissionais acadêmicos, que costumam estar mais envolvidos com as fases de diagnóstico e planejamento da obra, e menos com a execução.

Pietroforte e Aboulezz (2005), em pesquisa realizada junto a trabalhos publicados Journal Management Engineering (JME), apontam redução gradativa (desde 1985 até 2002) de artigos submetidos a esse periódico oriundos de profissionais do mercado ("practioners"), indicando uma possível lacuna entre a prática e a teoria, com queda nas contribuições obtidas das indústrias e acréscimo de trabalhos acadêmicos.

Ainda em âmbito internacional, existem também vários estudos a respeito da seleção e contratação de empresas para execução de obras "novas", o que não acontece com a mesma intensidade para os casos de obras de manutenção, consideradas de menor porte (YIU et al., 2002).

De todo modo, discussão relacionada com as técnicas utilizadas para essa seleção é apresentada por Karam (2005) e Tenah (2000), que avaliam as vantagens da utilização de uma empresa gerenciadora que atue desde a definição dos projetos até a execução ("designbuild"), ou de empresas diferentes responsáveis em cada uma das etapas do serviço ("design-bid-build"), com enfoque especial para obras públicas em países desenvolvidos

Segundo esses autores, nos EUA, por exemplo, os estados possuem leis específicas para definir regras claras para contratação das empresas para as suas obras púbicas, o que é justificado pela impossibilidade de negociação direta com os participantes para esse tipo de serviço, sob pena de se caracterizar algum tipo de favorecimento.

Ainda nesse aspecto, Gao et al. (2002) apresentam revisão da literatura com vários pesquisadores que discutem os chamados fatores de sucesso para o desenvolvimento de projetos relacionados tanto com obras de grande porte como obras pequenas, como são classificadas as atividades de manutenção.

É comum também se encontrar pesquisas desenvolvidas nas áreas de engenharia de produção e arquitetura, em âmbito nacional e internacional, que abordam o tema 
"retrofit" ${ }^{12 " ~ d a s ~ c o n s t r u c ̧ o ̃ e s, ~ q u e ~ p o d e ~ t e r ~ u m ~ e n f o q u e ~ t a n t o ~ d e ~ s i m p l e s ~ r e f o r m a ~ d a ~}$ edificação até uma reconstrução completa do imóvel, a depender dos objetivos da intervenção e do seu estado de conservação.

No Brasil, a área de conhecimento que mais se relaciona com o tema do presente trabalho é a de Tecnologia do Ambiente Construído, cuja organização nacional atualmente fica a cargo da Antac - Associação Nacional do Ambiente Construído, comunidade criada em 1987 com o objetivo de ordenar as pesquisas diversas correlatas desenvolvidas no país. Desde então, vem crescendo o número de professores e alunos de pós-graduação vinculados, o que gerou a necessidade da criação de diversos grupos de pesquisa.

Estudo realizado por Pithan et al. (2005) apresenta dados referentes à produção científica no Brasil tomando como referência levantamento realizado nos trabalhos publicados nos eventos do Entac (Encontro Nacional de Tecnologia do Ambiente Construído) realizados nos anos de 1993, 1995, 1998, 2000 e 2002. Os dados coletados indicaram algumas informações relevantes, como a predileção dos autores brasileiros em publicar as suas pesquisas em anais de eventos, priorizando-os em relação à publicação em periódicos, uma grande concentração de trabalhos oriundos da USP, UFSC e UFRGS (juntos representam 70\% dos artigos publicados), e crescente utilização de estudos de caso como estratégia de pesquisa.

Levando-se em conta essas informações, em pesquisa realizada nos dois principais eventos de âmbito nacional, Entac e Sibragec (Simpósio Brasileiro de Gestão e Economia da Construção), verifica-se a existência de poucos estudos que abordem de forma específica o tema de planejamento e gestão de obras de manutenção de fachada em edificações habitadas, o que caracteriza o ineditismo do presente trabalho no país.

Os grupos de pesquisa da Antac, assim como os seus respectivos representantes nas universidades mais atuantes no setor, como a USP, UFSC, UFRGS, entre outras, possuem trabalhos desenvolvidos ao longo dos últimos 20 anos em temas correlatos que podem servir como referenciais para a pesquisa em estudo, assim como pesquisas apresentadas em congressos do Ibracon (Instituto Brasileiro do Concreto).

\footnotetext{
12 O conceito de "retrofit" está melhor discutido no item 2.3 - Manutenção: conceituação teórica.
} 
O estudo específico do presente trabalho pode ser enquadrado dentro de alguns temas de pesquisa abordados pelos grupos de estudo existentes na Antac, uma vez que envolve aspectos como planejamento e controle da produção, tecnologia de processos e materiais, diagnóstico e prognóstico de patologias, análise de custos e tomada de decisões, questões jurídicas de responsabilidade civil e contratuais, segurança do trabalho. Trata-se, portanto, de um trabalho cuja complexidade reside na variedade e simultaneidade de fatores atuantes e influentes no produto estudado.

Em especial no caso do gerenciamento de obras em condomínios, são verificados no Brasil trabalhos desenvolvidos em centros de pesquisa de engenharia civil com ênfase para tecnologia de gestão e engenharia de produção.

Trabalho elaborado por Bezerra (2000) apud Meira e Heineck (2002) indica a gestão terceirizada dos condomínios como elemento de suporte para as ações de manutenção. Esses autores destacam ainda a importância do gerenciamento nesse tipo de atividade, com pequena quantidade de estudos, entretanto, que abordem o grau de satisfação dos usuários na qualidade gerencial exercida.

No livro Técnicas de inspeção e manutenção predial (GOMIDE, 2006) os autores discutem a importância das vistorias rotineiras do estado de conservação das edificações como parte integrante e fundamental de uma gestão técnica condominial, com base também em estudos desenvolvidos pelo Ibape (Instituto Brasileiro de Avaliações e Perícias de Engenharia)

Alguns trabalhos recentes desenvolvidos na EPUSP especialmente relacionados com tema foram a dissertação apresentada por Resende (2004) e as monografias de Maccaferri (2005) e Monacelli (2005), que tratam da manutenção, contratação e acompanhamento de obra de recuperação de revestimento de fachada em edificações habitadas e em uso. São discutidos a importância do planejamento como elemento orientativo para o adequado desenvolvimento de obras dessa natureza, e problemas diversos encontrados em estudos de caso.

Dentre as publicações apresentadas pelo autor da presente pesquisa e relacionadas com o tema em estudo se destacam a dissertação de mestrado, intitulada "Descolamento dos revestimentos cerâmicos de fachada na cidade do Recife", defendida na EPUSP em 2001, 
a participação no capítulo "Patologia das Estruturas" do livro Concreto: ensino, pesquisa e extensão (2005), além de artigos diversos apresentados em congressos internacionais (Qualicer, Siabe, Conpat) e nacionais (SBTA, Entac, Ibracon, Simpusp) ${ }^{13}$.

13 Informações detalhadas podem ser encontradas em <http://lattes.cnpq.br/4870687041882933> Plataforma Lattes. 


\subsection{Manutenção - conceituação}

O termo manutenção ${ }^{14}$ pode ser entendido como o conjunto de ações tomadas com o objetivo de conservar as condições de funcionalidade de um bem ao longo da sua existência. Tal conceito remonta ao início do século passado, quando as atividades desenvolvidas pela incipiente industrialização começavam a exigir níveis de produção para atendimento das demandas incompatíveis com as constantes paradas para reparos e consertos de máquinas.

Com a evolução da indústria seriada e a constante busca por otimização de processos, as ações de manutenção passaram a ser mais ativas, no sentido de se prevenir quanto à ocorrência de problemas e conseqüentes paradas na produção. Foi quando as indústrias passaram a adotar as manutenções de rotina, que já deviam constar dos seus estudos de tempos para avaliação da produtividade. Uma evolução nesse conceito foi a análise prognóstica dos problemas potenciais a partir do acompanhamento constante do estado de conservação dos componentes, reduzindo ainda mais as perdas de tempo com maquinário parado, além da substituição prematura de componentes (informações melhor detalhadas a respeito dessa evolução estão descritas por Resende, 2004).

Infelizmente, a indústria da construção civil, especialmente no caso de edifícios regidos por regime condominial, ainda carece de um maior amadurecimento desses conceitos, que passa por questões técnicas, gerenciais e até de conscientização junto aos usuários das suas reais necessidades.

Os manuais de operação, uso e manutenção ${ }^{15}$ entregues pelas construtoras aos usuários, em sua maioria, abordam ações diversas de manutenção a serem efetuadas pelos

${ }^{14}$ Conforme descrito na NBR 5.674 (ABNT, 1999), a manutenção de edifícios pode ser entendida como o "conjunto de atividades a serem realizadas para conservar ou recuperar a capacidade funcional da edificação e de suas partes constituintes de atender às necessidades e segurança dos usuários".

${ }^{15}$ A NBR 14.037 (ABNT, 1998) conceitua manual de operação, uso e manutenção como “documento que reúne apropriadamente todas as informações necessárias para orientar as atividades de operação, uso e manutenção da edificação". Ainda segundo essa norma, entende-se por operação atividades a serem realizadas para controlar o funcionamento da edificação, por uso, as atividades normais realizadas pelos usuários dentro 
usuários do edifício, classificadas, então, como preventivas ou preditivas, a depender do caso.

A diferença entre a manutenção preventiva e preditiva, como destaca Resende (2004), é que a primeira é realizada de maneira rotineira, obedecendo a uma periodicidade estabelecida previamente conforme as características de cada componente, enquanto a preditiva possui um caráter mais ativo, dinâmico, pois as ações são tomadas a partir do monitoramento contínuo do estado de conservação, tal como uma manutenção preventiva baseada em condições. Assim, a manutenção preditiva prevê a realização de checagem dos componentes precedendo uma efetiva intervenção, diminuindo as perdas devidas a substituições prematuras.

Para Perez (1988), manutenção preventiva é realizada em intervalos de tempo periódicos pré definidos a partir de aspectos técnicos, com a função detectar e corrigir defeitos, evitando a ocorrência de falhas. Já a manutenção corretiva é motivada por uma exigência funcional do bem, cujas funções não mais oferecem condições de uso em sua normalidade.

A NBR 5.674 (ABNT, 1999), no seu item 6.4, apresenta três tipos de manutenção necessários a depender de cada caso, conforme se segue:

- Manutenção rotineira: serviços rotineiros mais simples, executados com pessoal e equipamento disponíveis na edificação, atendendo a um fluxo constante.

- Manutenção planejada: atividades programadas a partir da expectativa de durabilidade dos materiais e componentes da edificação, de relatórios de inspeção elaborados, ou mesmo de eventuais solicitações dos usuários.

- Manutenção não planejada: intervenções de caráter imediato decorrente da necessidade de se evitar graves riscos ou prejuízos pessoais ou patrimoniais aos usuários ou proprietários, não previstos na manutenção planejada ou rotineira.

das condições ambientais adequadas e, por manutenção, as atividades realizadas para conservar ou recuperar a capacidade funcional da edificação. 
Em virtude dessa clara difusão de conceitos, para a presente pesquisa a abordagem realizada por Lichtenstein (1985) parece bastante aplicável, uma vez que associa a manutenção com o desempenho dos componentes, também observado em Isaia (2005).

Com o decorrer do tempo, as partes da edificação, e por conseqüência o seu todo, apresentam uma natural queda de desempenho, cujo comportamento varia conforme as características dos componentes e a sua interação com o meio, as chamadas condições de exposição. Caso se considere um patamar mínimo de desempenho abaixo do qual o edifício não mais cumprirá de forma adequada as suas funções, deve-se então evitar que a deterioração natural provoque uma queda suficiente para atingir esse nível mínimo, conforme destacado no Gráfico 1. As intervenções servem para elevar o patamar de desempenho, mesmo considerando as quedas residuais, retardando a sua chegada ao patamar mínimo exigido.

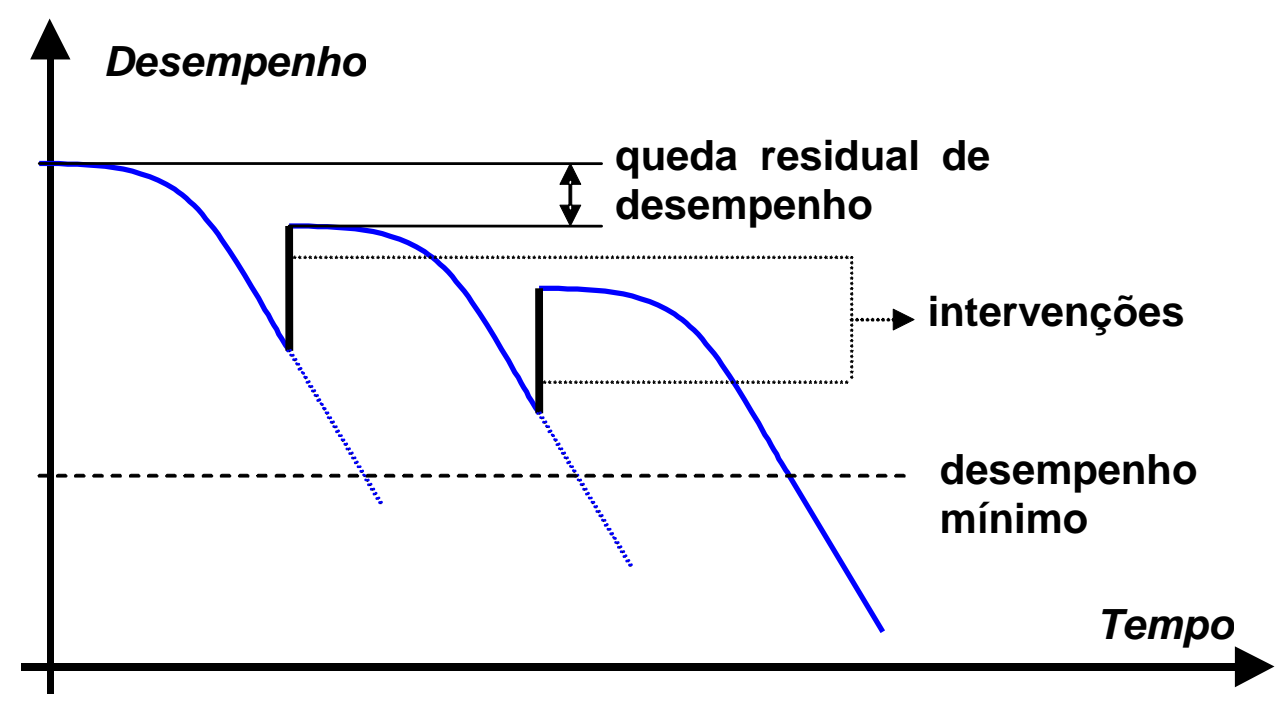

Gráfico 1 - Expressão gráfica da queda de desempenho natural de uma edificação com o tempo (extraído de Lichtenstein (1985)).

Esses conceitos podem ser também discutidos observando o Gráfico 2, igualmente adaptado de Lichtenstein (1985). A fim de evitar que a edificação atinja o seu patamar mínimo estipulado de desempenho, são realizadas as atividades de manutenção rotineiras (que podem ser classificadas também como regulares ou preventivas), adotadas de forma programada. 
Entretanto, quando esse nível mínimo é alcançado, são necessárias intervenções de recuperação (ou manutenção corretiva), tomadas com o objetivo de retomar o desempenho a um patamar aceitável.

Por fim, há ainda situações em que a edificação já se encontra abaixo do nível mínimo de desempenho antes mesmo da sua utilização, seja devido a deficiências de projeto ou de execução. Nesses casos são realizadas atividades de reforço para garantir o desempenho esperado.

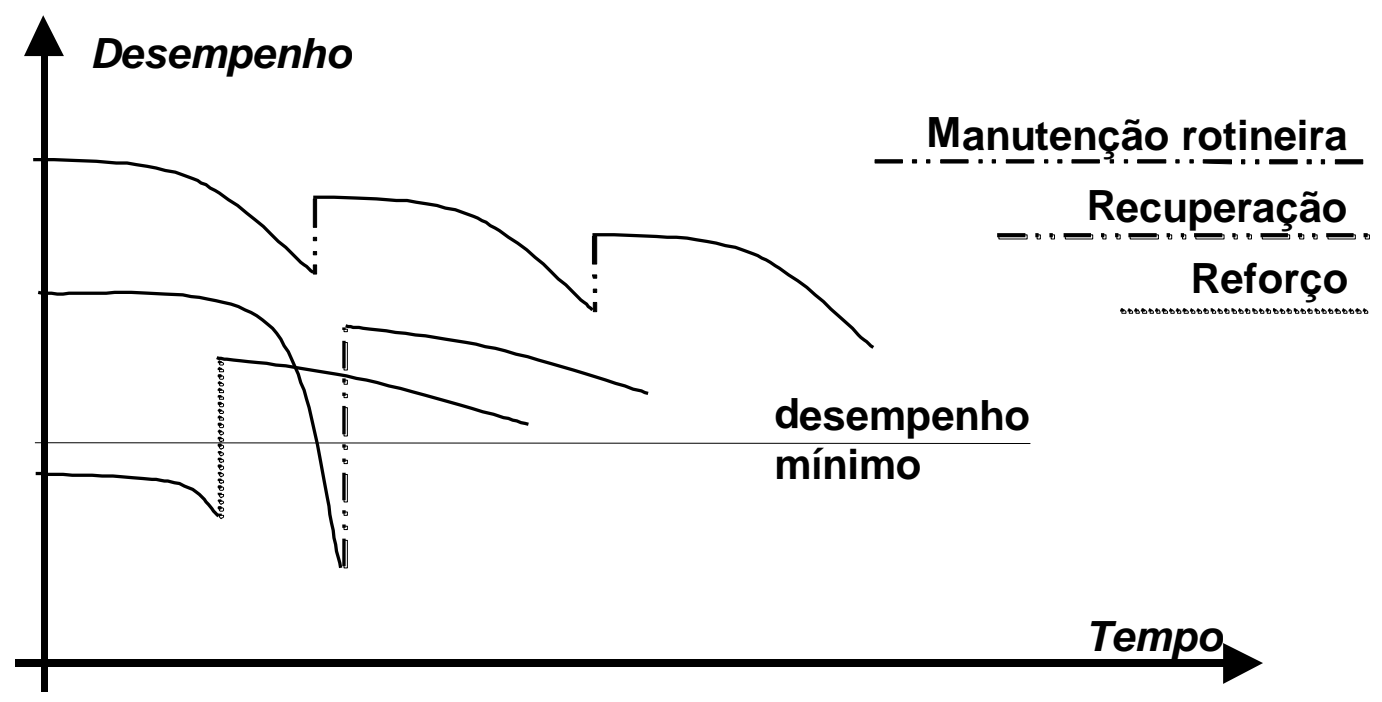

Gráfico 2 - Evolução do desempenho da edificação após as atividades de manutenção (adaptado de Lichtenstein (1985)).

Em verdade, o que se observa com freqüência é que a demanda maior por serviços de manutenção em fachada ocorre por ações corretivas, quando a sua queda de desempenho já está provocando uma perda significativa da sua capacidade funcional. É o caso, por exemplo, do desprendimento de revestimentos aderidos, como placas cerâmicas e ornamentais (mármore e granito), cujas conseqüências podem ser bastante onerosas do ponto de vista material (desvalorização do imóvel) e, principalmente, pessoal, devido ao risco de queda de componentes de alturas elevadas.

Pesquisa realizada por Oliveira et al. (2006) junto a síndicos de edifícios residenciais e comerciais na cidade de Porto Alegre aponta para a avaliação equivocada de administradores de condomínios da necessidade de serviços de manutenção baseada em problemas estéticos nas fachadas, cabendo o conserto de avarias ou falhas apenas nos casos mais extremos. Esses autores entendem a manutenção como uma atividade de 
gerenciamento de riscos, na medida em que tendem a manter o desempenho dos componentes acima dos níveis mínimos de tolerância.

Outra questão também relevante para discussão é a partir de qual etapa de desenvolvimento do empreendimento se deve tratar da manutenção. Perez (1988) enfatiza a importância de se pensar nessa atividade desde a fase de projeto, quando as deficiências podem ser discutidas e corrigidas a custo praticamente nulo em se comparado com intervenções que eventualmente sejam necessárias.

O Gráfico 3 apresenta a chamada Lei de Sitter, ou Lei dos cinco (Sitter, 1983), que ilustra o incremento do custo e eficiência da atividade de manutenção de acordo com a maior brevidade que a mesma é analisada e discutida.

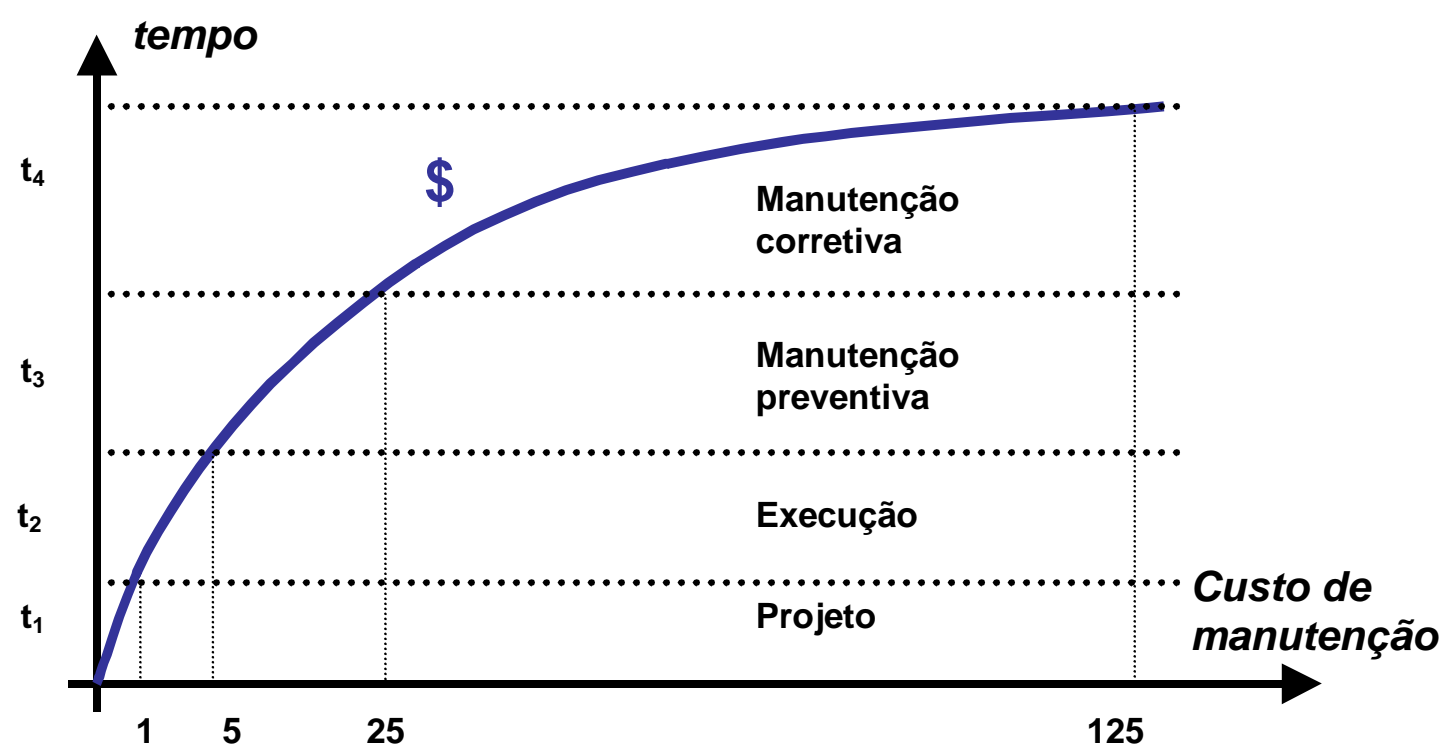

Gráfico 3 - Gráfico ilustrativo do aumento do custo com manutenção com o passar do tempo (Lei de Sitter)

Esse conceito é também discutido em trabalho elaborado por Alani et al. (2001) no qual é apresentado estudo de caso teórico que avalia financeiramente a evolução dos custos de manutenção conforme a depreciação do prédio e o tempo. Tais análises são explicitadas por meio de gráficos (custos $x$ tempo) que expressam de forma clara a evolução gradativa dos investimentos necessários para a manutenção com o passar do tempo (Gráfico 4). 


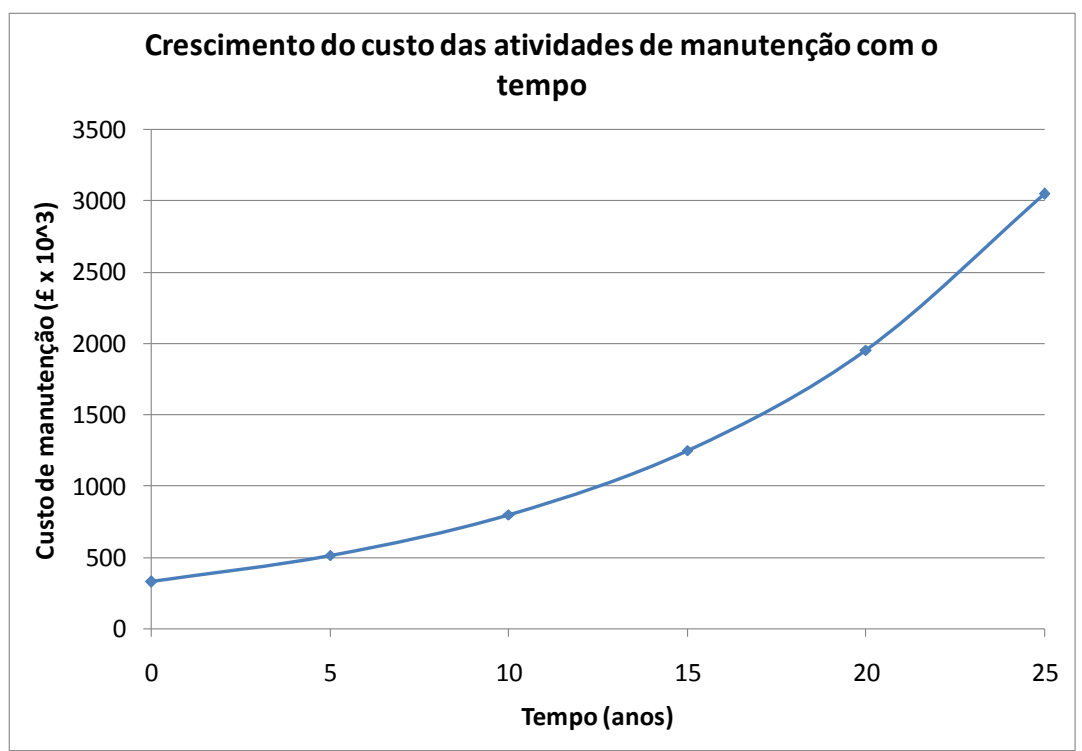

Gráfico 4 - Exemplo do crescimento exponencial do custo de manutenção com o tempo (adaptado de Alani et al.(2001)).

\subsection{Agentes envolvidos na atividade}

Numa obra de manutenção realizada em um condomínio, vários são os agentes envolvidos, cada qual com os seus interesses particulares. Na Tabela 2 é apresentada definição dos agentes e suas funções, observando-se também uma comparação entre a indústria seriada e a construção de edifícios, adaptado de Gehbauer (2004).

Tabela 2 - Descrição de agentes e suas funções no desenvolvimento de atividades (adaptado de Gehbauer, 2004).

\begin{tabular}{|c|c|c|c|c|}
\hline \multirow[b]{2}{*}{ Agente } & \multirow[b]{2}{*}{ Atividade exercida } & \multicolumn{3}{|c|}{ Profissional envolvido } \\
\hline & & Indústria seriada & $\begin{array}{c}\text { Construção civil } \\
\text { Imobiliária }\end{array}$ & $\begin{array}{l}\text { Construção civil } \\
\text { Manutenção }\end{array}$ \\
\hline Investidor & $\begin{array}{l}\text { Proprietário do negócio, } \\
\text { aplicador dos recursos. }\end{array}$ & Fabricante & $\begin{array}{l}\text { Incorporador ou } \\
\text { investidor }\end{array}$ & Condomínio \\
\hline Projetista & $\begin{array}{l}\text { Concepção técnica e } \\
\text { especificações, conforme } \\
\text { anseios do investidor. }\end{array}$ & Fabricante & $\begin{array}{l}\text { Construtor ou } \\
\text { escritório } \\
\text { independente } \\
\end{array}$ & Consultores \\
\hline Construtor & $\begin{array}{l}\text { Execução da obra, } \\
\text { responsável por mão de } \\
\text { obra, materiais e } \\
\text { equipamentos. }\end{array}$ & Fabricante & $\begin{array}{l}\text { Construtor ou } \\
\text { empreiteiros }\end{array}$ & $\begin{array}{c}\text { Empresas } \\
\text { especializadas }\end{array}$ \\
\hline Cliente & $\begin{array}{l}\text { Usuário, a quem se busca } \\
\text { satisfazer. }\end{array}$ & Usuário & Usuário final & Condomínio \\
\hline Outros & $\begin{array}{l}\text { Financiamento, gerência, } \\
\text { fiscalização. }\end{array}$ & Auditor & Consultores & $\begin{array}{c}\text { Administradora ou } \\
\text { gerente }\end{array}$ \\
\hline
\end{tabular}


Como se pode observar, na indústria seriada tradicional o investidor, o projetista e o construtor são componentes de uma mesma empresa, o que facilita o desenvolvimento de atividades contínuas de controle e aperfeiçoamento. Isso já não ocorre na construção civil, e pode ser ainda mais crítico nas obras de manutenção, quando cada um dos agentes pode ser desempenhado por sujeitos diferentes.

Vieira Netto (1988) salienta a importância de que sejam claramente identificados os indivíduos que representem cada um dos agentes indicados, permitindo maior agilidade na discussão e tomada de decisões dentro da obra. Meira e Heineck (2004) comentam que as ações de manutenção das áreas comuns, cuja responsabilidade é de todos os usuários, deve ser gerenciada pela administração condominial.

Para Sanvido e Riggs (1993) dentre os agentes envolvidos no gerenciamento das atividades de intervenção em edificações habitadas devem ser citados proprietários, projetistas, construtores e usuários, que compartilham uma série de restrições no desenvolvimento das suas ações.

Attalla e Hegazy (2003) enfatizam a importância do envolvimento prévio dos agentes para o sucesso da intervenção, em estudo a respeito das atividades de gerenciamento de edificações em uso no Canadá, citando as figuras do arquiteto, do proprietário e do gerenciador. A cultura local, nesse caso, considera o arquiteto como responsável pelas etapas de construção da obra, desde a concepção até a execução.

Especialmente no caso das obras de manutenção de fachada em edificações habitadas, analisando a partir da Tabela 2, verifica-se muitas vezes a inexistência, devido ao desconhecimento ou simples necessidade de redução de custos, da figura do gerenciador, cujas funções acabam sendo exercidas pelo próprio condomínio, de forma pouco eficiente.

Bezerra (2000) apud Meira e Heineck (2002) destaca a importância da atividade de gerenciamento profissional para manutenção de edificações em substituição da cultura de autogestão, conduzida por condôminos que administram o bem sem o auxílio de terceiros. Tal opinião é destacada também na NBR 5674 (ABNT, 1999), que declara que essa atividade não pode ser efetuada de maneira improvisada, mas com acentuado rigor técnico e desenvolvida por profissionais de comprovada capacitação. 
Yiu et al. (2002) chamam a atenção para a importância do gerenciador (empresa especializada de consultoria) para auxiliar no gerenciamento desse tipo de serviço, uma vez que o mesmo deve dispor de um banco de dados valioso a respeito de aspectos relevantes para o desenvolvimento dos serviços, e que certamente não estão disponíveis facilmente para os contratantes (condomínio). Ainda segundo os autores, a inexistência dessa figura concorre para a ocorrência de um maior número de problemas de ordem técnica ou operacional que podem contribuir para o insucesso da atividade.

Essa opinião também é apresentada por Resende (2004), que propõe que os edifícios devam possuir empresa ou profissional especializado para assumir a responsabilidade dos serviços de manutenção, salientando que no Brasil essa função é normalmente exercida pelo síndico, em face da inexistência de uma visão de mais longo prazo.

O acompanhamento do desenvolvimento desse tipo de serviço por especialistas foi tema também de encarte publicado em 2008 pelo Jornal do Commercio ${ }^{16}$, de Pernambuco, que aborda a importância da contratação, pelo condomínio, de profissional habilitado para coordenar todas as etapas da obra, passando pelo diagnóstico do problema, especificação de materiais e quantitativos, apoio ao julgamento das propostas e fiscalização da execução dos serviços.

Para efeito do presente trabalho, entende-se a figura do gerenciador ${ }^{17}$ como de primordial importância para o sucesso do empreendimento, a quem compete as funções de projeto, planejamento (programação, orçamento, seleção e contratação) e acompanhamento dos serviços.

16 Informação disponível em: <http://jc.uol.com.br/jornal/2008/01/31.php>. Reforma com um especialista. Acesso em: 01 fev. 2008.

17 O gerenciador descrito nessa tese deve ser um profissional credenciado junto ao CREA, com experiência nas áreas de gestão e tecnologia, e habilidade para o tratamento interpessoal junto aos representantes do condomínio e da empresa executante da obra. 


\section{FASE EXPLORATÓRIA - EXPOSIÇÃO DE CASOS NÃO ORIENTADOS}

O objetivo desse item é apresentar relatos de 4 casos de gestão realizada de forma não orientada em obras de manutenção de revestimento de fachada. As avaliações críticas, associadas aos dados obtidos na revisão bibliográfica, possibilitaram a proposição do método de gestão defendido no trabalho.

Importante ressaltar que, no presente capítulo, não há pretensão de discutir a adequação das diversas ações adotadas em cada uma das obras, e sim apenas fazer uma descrição do que foi efetuado.

Em cada caso são destacadas as principais dificuldades encontradas e os seus aspectos particulares, que podem ser também contempladas no registro fotográfico apresentado no Anexo A. Ao final do capítulo, é apresentada a Tabela 7 indicando os principais fatores de sucesso (e insucesso) envolvidos nesses casos, além de pesquisa desenvolvida por Lordsleem Jr et al. (2007) em outras 5 obras de manutenção de fachada realizadas na cidade do Recife, contemplando análise crítica de aspectos técnicos e operacionais.

Para uma melhor orientação, as características básicas de cada obra estão apresentadas na Tabela 3, e os tópicos de análise estão divididos conforme as etapas de gestão propostas na presente pesquisa.

Tabela 3 - Descrição das características básicas dos casos em estudo.

\begin{tabular}{|c|c|c|c|c|c|}
\hline & $\begin{array}{c}\text { Área de } \\
\text { fachada }\left(\mathrm{m}^{2}\right)\end{array}$ & $\begin{array}{c}\text { Tipo de } \\
\text { revestimento }\end{array}$ & $\begin{array}{c}\text { Ano de } \\
\text { construção }\end{array}$ & $\begin{array}{c}\text { № de pvtos } \\
\text { / aptos }\end{array}$ & Intervenção realizada \\
\hline Edf A & 10.000 & $\begin{array}{l}\text { Porcelanato } \\
(40 \times 40) \mathrm{cm}\end{array}$ & 1996 & $33 / 33$ & $\begin{array}{c}\text { Substituição das placas identificadas } \\
\text { com som cavo (parcial). }\end{array}$ \\
\hline Edf B & 2.900 & $\begin{array}{l}\text { Semi grês } \\
(20 \times 20) \mathrm{cm}\end{array}$ & 1992 & $23 / 69$ & $\begin{array}{l}\text { Substituição completa das } \\
\text { cerâmicas escuras e parcial das } \\
\text { claras. }\end{array}$ \\
\hline Edf C & 5.000 & $\begin{array}{l}\text { Pastilha } \\
(2 \times 2) \mathrm{cm}\end{array}$ & 1978 & $15 / 15$ & $\begin{array}{l}\text { Remoção da pastilha original e } \\
\text { aplicação de mármore e granito. }\end{array}$ \\
\hline Edf D & 7.000 & $\begin{array}{l}\text { Semi grês } \\
(10 \times 20) \mathrm{cm}\end{array}$ & 1992 & $18 / 18$ & $\begin{array}{c}\text { Substituição das placas identificadas } \\
\text { com som cavo (parcial). }\end{array}$ \\
\hline
\end{tabular}

Em todas as obras foi elaborado um documento formal de referência (Edital) entregue às empresas concorrentes para o serviço, contemplando descrição das condições 
gerais da obra, como: condições de pagamento, prazo de execução, planilha básica de referência sem custos, procedimentos executivos, e aspectos de segurança, comportamento e higiene dos funcionários. 


\subsection{Avaliação das necessidades do prédio}

Nesse tópico são discutidos aspectos relacionados com as razões que geraram a necessidade da intervenção, e as atividades recomendadas para a intervenção.

Em três dos casos avaliados (Edf. A, B e D), a intervenção foi motivada pela ocorrência de descolamento das placas originais espalhado pelas áreas diversas da fachada, enquanto no Edf. C o condomínio resolveu alterar o revestimento da fachada por questões exclusivamente estéticas.

Nos casos A e B foram propostas aos condôminos duas alternativas de intervenção: substituição completa das placas cerâmicas da fachada, e substituição apenas das placas identificadas como soltas no ensaio de percussão (parcial). Em ambos os casos a escolha foi pela opção menos onerosa, de substituição parcial das placas. Já no caso $D$, como o descolamento aparecia de forma pronunciada apenas em um trecho da fachada norte, indicando a ocorrência de algum fator de influência específico naquele local, foi proposta apenas a segunda opção.

No caso $C$, a análise técnica inicial se restringiu aos ensaios de resistência de aderência à tração direta para verificar a capacidade resistente da argamassa de emboço original para suportar o novo revestimento externo em mármore e granito, uma vez que já havia a decisão de se fazer a substituição. 


\subsection{Análise e critérios para a contratação}

Conforme observado na Tabela 4, em três dos casos apresentados ( $A, B$ e C) o prazo previsto para a conclusão da obra foi aquém do executado. Dentre eles, entretanto, apenas o caso $C$ teve as quantidades de serviços mantidas até o final da obra, enquanto que nos casos A e B aconteceram aumentos expressivos nas quantidades, o que reflete, naturalmente, no tempo necessário para a execução.

Percebe-se nesses prédios que o prazo inicialmente previsto para conclusão das obras foi curto em relação ao tipo de serviço que seria executado. É necessário considerar uma natural maior dificuldade para tratamento de aspectos operacionais em obras realizadas com a edificação em uso, como o cumprimento de horários especiais, necessidade de limpeza constante das áreas sociais, reparo imediato de eventuais danos causados (quebra de vidros da janela, por exemplo), todos com reflexo na evolução dos serviços. Por isso, a produtividade esperada nesses casos deve ser inferior àquela normalmente obtida em "obras novas".

Já no caso $D$, a quantidade de serviços executados foi inferior àquela prevista originalmente, o que provocou uma redução do prazo para execução do serviço. Para todas as propostas foi exigido das empresas concorrentes a apresentação de cronograma físico financeiro de execução.

Tabela 4 - Prazos de execução previstos e executados nas obras em estudo.

\begin{tabular}{c|c|c}
\hline & Prazo previsto & Prazo executado \\
\hline Edf A & 6 meses & 24 meses \\
\hline Edf B & 6 meses & 12 meses \\
\hline Edf C & 6 meses & 12 meses \\
\hline Edf D & 6 meses & 4 meses \\
\hline
\end{tabular}

Como os condomínios já dispunham de boa parte dos recursos previstos para a obra antes do seu início, em nenhum caso chegou-se a cogitar a possibilidade de condicionar o início dos serviços à formação de caixa, e nem foram discutidos aspectos relacionados com as condições ambientais mais favoráveis para a obra.

Antes da cotação de preços no mercado de empresas do ramo para execução das obras, em todos os casos foi apresentada ao condomínio uma planilha básica orçamentária 
contemplando itens de serviço, quantidades e preços unitários. O objetivo dessa atividade foi proporcionar uma estimativa inicial dos custos para que se pudesse verificar a capacidade financeira do condomínio para executar a obra, e também para balizar a avaliação das propostas encaminhadas.

Em todos os casos as quantidades previstas foram medidas na sua integridade, isto é, não foi efetuado nenhum tipo de segmentação por trechos, sendo colocado coeficiente de majoração entre $3 \%$ e $5 \%$.

Os preços adotados como referência foram obtidos a partir de planilhas de obras similares executadas por empresas do ramo na região. A Tabela 5 apresenta de forma sucinta os preços de referência e as propostas iniciais para cada uma das obras, além dos orçamentos contratado e executado.

Apesar de não estar explícito no documento enviado às empresas concorrentes, as propostas vencedoras foram aquelas que apresentaram menor custo, a menos no caso $D$, em que havia uma predileção por parte do condomínio. Cabe salientar que nenhuma das propostas enviadas pelas empresas apresentou, inicialmente, qualquer tipo de alteração referente às informações contidas no documento (Edital), seja quanto aos procedimentos, materiais ou mesmo de quantitativos.

Tabela 5 - Tabela indicativa dos preços de referência, propostas apresentadas pelas empresas concorrentes, orçamento contratado e executado.

\begin{tabular}{|c|c|c|c|c|c|c|}
\hline & $\begin{array}{l}\text { Preço de } \\
\text { referência }\end{array}$ & $\begin{array}{c}\text { Proposta } \\
\text { contratada }\end{array}$ & $\begin{array}{l}\text { Propostas } \\
\text { diversas }\end{array}$ & $\begin{array}{l}\text { Orçamento } \\
\text { executado }\end{array}$ & $\begin{array}{c}\text { Diferença } \\
\text { (refer - contr) }\end{array}$ & $\begin{array}{c}\text { Diferença } \\
\text { (exec-contr) }\end{array}$ \\
\hline Edf A & $\mathrm{R} \$ 106.000,00$ & $\mathrm{R} \$ 85.000,00$ & $\begin{array}{l}\mathrm{R} \$ 146.000,00 \\
\mathrm{R} \$ 405.000,00\end{array}$ & $\mathrm{R} \$ 300.000,00$ & $\begin{array}{c}\mathrm{R} \$ 21.000,00 \\
25 \% \\
\end{array}$ & $\begin{array}{c}R \$ 215.000,00 \\
253 \% \\
\end{array}$ \\
\hline Edf B & $\mathrm{R} \$ 155.000,00$ & $\mathrm{R} \$ 195.000,00$ & $\mathrm{R} \$ 196.000,00$ & $\mathrm{R} \$ 422.000,00$ & $\begin{array}{c}-R \$ 40.000,00 \\
-26 \% \\
\end{array}$ & $\begin{array}{c}\mathrm{R} \$ 227.000,00 \\
116 \% \\
\end{array}$ \\
\hline Edf C & $\mathrm{R} \$ 283.000,00$ & $\mathrm{R} \$ 232.000,00$ & Não informado & $\mathrm{R} \$ 232.000,00$ & $\begin{array}{c}\mathrm{R} \$ 50.000,00 \\
22 \% \\
\end{array}$ & $\begin{array}{c}\mathrm{R} \$ 0,00 \\
-\end{array}$ \\
\hline Edf D & $\mathrm{R} \$ 57.000,00$ & $\mathrm{R} \$ 85.000,00$ & $\mathrm{R} \$ 63.000,00$ & $\mathrm{R} \$ 45.000,00$ & $\begin{array}{c}-R \$ 28.000,00 \\
-33 \%\end{array}$ & $\begin{array}{c}-R \$ 40.000,00 \\
-47 \%\end{array}$ \\
\hline
\end{tabular}

No caso A, a razão para elevada diferença entre o orçamento executado e o contratado foi a equivocada interpretação do problema, uma vez que a quantidade de 
placas cerâmicas previstas para substituição (5.000 unidades) foi muito inferior à necessária para a execução da obra (21.000 unidades).

Problema semelhante ocorreu no Edf. B, quando a área estimada para a execução dos serviços $\left(2.900 \mathrm{~m}^{2}\right)$ era bastante inferior à real executada $\left(4.600 \mathrm{~m}^{2}\right)$. Em ambos os casos os problemas só foram detectados com a obra em andamento. Já no caso D aconteceu o contrário, isto é, a quantidade prevista inicialmente foi aquém da executada.

Já no edf. C não houve problemas relacionados com aditivos contratuais ou mesmo equívocos de quantitativos. Esse indicador positivo pode ser creditado à exaustiva conferência das quantidades medidas em projeto (pelo arquiteto e pela gerenciadora) no local, e também pela empresa executante, tudo isso antes do fechamento do contrato. Esse procedimento atrasou em cerca de 15 dias o início das atividades, compensado pela menor ocorrência de problemas posteriores.

Quanto às diferenças entre os preços de referência e as propostas apresentadas, observa-se um valor relativamente constante, entre $25 \%$ e $30 \%$. Esses valores podem ser considerados elevados, mas refletem também a pequena quantidade de propostas apresentadas. A razão pelo pouco interesse das empresas em participar da obra pode ser o alto nível de exigência para a habilitação, explicitado no documento que thes foi enviado, especialmente no tocante à regularidade fiscal e trabalhista.

Conforme a experiência do autor, observa-se um grande número de empresas atuantes nessa área com baixa qualificação, reflexo da reduzida exigência por parte dos contratantes (condomínio, na maioria dos casos). Com isso, quando se apresentam regras para seleção e execução dos serviços, essas empresas preferem optar pela não participação na obra. A despeito do menor leque de opções, esse fato pode ser entendido como satisfatório, uma vez que, desde a etapa inicial, já ocorre uma filtragem natural.

Uma vez que as obras tiveram o seu início em épocas bastante próximas, as exigências contratuais em todos os casos foram bastante semelhantes, destacando-se os pontos a seguir alinhados:

- Não houve previsão de ajuste ou correção monetária dos valores propostos.

- As obrigações trabalhistas estavam previstas (INSS, FGTS), entretanto os valores não eram retidos no pagamento, sendo apenas solicitada a apresentação da guias de 
quitação dos débitos. Porém, como tal atividade era desenvolvida pela própria administração do condomínio, muitas vezes não era cumprida à risca.

- Em todos os casos os pagamentos eram efetuados por medição de serviço executado, sem nenhum tipo de restrição devido a atrasos em relação ao cronograma físico financeiro inicialmente apresentado.

- Não houve qualquer tipo de exigência quanto às quantidades e tipos de equipamentos para o início dos serviços, o que provocou, em todos os casos, uma evolução inicial das atividades bastante lento, com repercussões observadas no final da obra, para cumprimento dos prazos.

- Aspectos diversos de segurança, higiene e comportamento dos funcionários estavam claramente explícitos em contrato, inclusive a autonomia da fiscalização para atuar no caso do seu descumprimento. No caso A, por exemplo, ocorreram problemas de comportamento dos funcionários e do próprio corpo técnico, e as cláusulas estabelecidas permitiram a tomada de decisões pela fiscalização que culminaram com a substituição da empresa executante inicialmente contratada, sem nenhum tipo de dano contratual para o condomínio.

- Em nenhum dos casos houve qualquer tipo de registro quanto ao estado de conservação das áreas sociais comuns e da vizinhança. Por conta disso, no caso A foi solicitado ao condomínio a realização de limpeza da fachada do edifício vizinho, ocupado por um hotel de alto padrão, sob a alegação da ocorrência de sujeira pronunciada. Uma avaliação realizada no local constatou que o problema levantado era muito mais decorrente da névoa salina, uma vez que ambos os prédios se situam na orla marítima, do que de sujeira proveniente da obra. Entretanto, como não foi efetuado registro anterior da situação de limpeza dos vidros da fachada, foi necessário realizar esse serviço adicional pelo condomínio.

Algumas das características contratuais observadas de modo particular em cada caso estão apresentados na Tabela 6. Interessante notar que, nos casos em que foi apresentado, o relatório final foi elaborado pela gerenciadora, e não pela empresa executante os serviços, não havendo, com isso, uma entrega formal da obra entre todos os envolvidos. 
Tabela 6 - Aspectos particulares de contrato observados nas obras em estudo.

\begin{tabular}{c|c|c|c|c}
\hline & Edf. A & Edf. B & Edf. C & Edf. D \\
\hline Tipo de contrato & $\begin{array}{c}\text { Por medição de serviço } \\
\text { executado }\end{array}$ & Global & $\begin{array}{c}\text { Por medição de } \\
\text { serviço executado }\end{array}$ \\
\hline $\begin{array}{c}\text { Relatório final da } \\
\text { obra }\end{array}$ & Sim & Não & Sim \\
\hline $\begin{array}{c}\text { Retenção de } \\
\text { pagamento }\end{array}$ & $\begin{array}{c}\text { Sim (de forma indireta } \\
\text { adiantamento para } \\
\text { compra de balancim) }\end{array}$ & Não & Sim & Sim \\
\hline $\begin{array}{c}\text { Presença de técnico } \\
\text { em tempo integral }\end{array}$ & Não & Sim & Alguns períodos & Não \\
\hline
\end{tabular}




\subsection{Acompanhamento dos serviços}

\subsubsection{Controle tecnológico}

Em todos os casos analisados o controle tecnológico de materiais e de produção foram realizados a partir do documento encaminhado às empresas concorrentes, que contemplava procedimentos executivos e atividades de controle dos materiais. Entretanto, uma vez que não havia qualquer tipo de ficha de verificação ou algo do gênero, esse acompanhamento não foi registrado de maneira formal, apenas por meio de ensaios de resistência de aderência à tração direta, efetuado pela própria empresa fiscal.

Os resultados desses ensaios eram repassados para o representante do condomínio na obra, em geral o próprio síndico, e constam do relatório final de conclusão dos serviços de cada obra. Em nenhum caso foi solicitado à empresa executante a realização de ensaios de caracterização dos materiais empregados, e nem a apresentação de certificados realizados pelos próprios fornecedores, o que poderia servir como um elemento de garantia de que aqueles materiais foram utilizados na obra.

A inexistência dessa comprovação de qualidade expõe tanto a fiscalização quanto a empresa executante à não comprovação de deficiência do material na eventual ocorrência de falhas.

\subsubsection{Controle operacional}

Como já anteriormente discutido, um dos problemas recorrentes observados foi o descumprimento dos prazos estipulados. Apesar de todas as obras disporem de cronogramas físicos, apresentados pelas empresas executantes, em nenhuma delas houve um devido acompanhamento comparativo entre o previsto e o real executado.

Apesar de ser visível o atraso dos serviços, em algumas situações agravado pelas falhas nas previsões das quantidades de serviços, a inexistência em contrato de algum tipo de relação entre os valores pagos e o cumprimento dos prazos tornava essa avaliação comparativa pouco eficaz.

Especialmente nos casos $A$ e $B$, onde as quantidades executadas foram muito além das previstas, houve uma insatisfação natural dos condôminos, principalmente pelo 
desconhecimento quanto aos prazos previstos para conclusão das obras. Em nenhum dos casos havia a prática de encaminhar ao condomínio a avaliação comparativa dos prazos.

Os pagamentos, em todos os casos, eram efetuados a partir das quantidades medidas, à exceção do Edf $\mathrm{C}$, onde ficou combinado, desde o início, que os valores seriam mensurados por meio das quantidades percentuais executadas.

A inexistência de exigência quanto aos equipamentos mínimos necessários para o início dos serviços levaram à ocorrência de fatos pouco comuns. Preocupado com a lenta evolução dos serviços, o condomínio do Edf. A resolveu custear a aquisição de um balancim elétrico, valor que era abatido gradualmente das parcelas de pagamento.

Por outro lado, questões relacionadas com segurança e comportamento dos funcionários, uma vez que estavam claramente definidas no documento enviado às empresas para concorrência, puderam ser controladas com maior rigor, não havendo, em nenhum dos casos estudados, qualquer tipo de acidente passível de registro.

O mesmo pode ser afirmado no tocante aos problemas de quebras de telhas na cobertura, vidros de janela, rasgos em telas de proteção, os quais, em todos os casos ocorridos, foram sanados com brevidade, sob pena das empresas terem parte do seu pagamento retido para o custeio de tais atividades.

No que se refere às áreas comuns dos prédios, para evitar maiores transtornos aos moradores, foram tomadas providências no sentido de protegê-las e liberá-las, quando possível. Essas ações foram evidentes nos casos do Edf. A e do Edf. D, nos quais havia quadra para prática de esportes próxima à fachada, obrigando um cuidado nas telas de proteção, mesmo considerando que as áreas só eram liberadas para uso quando do término dos horários de serviço.

Já no Edf. B e no Edf. C havia regiões de passagem de automóveis exatamente sob os panos de serviço, de modo que foi necessária a interdição da área durante a execução da obra no local. Essas áreas foram priorizadas para que a interdição durasse o menor período de tempo possível.

Um diferencial observado nos casos de estudo foi a presença de um encarregado (ou mestre geral) da empresa executante em tempo integral na obra. No caso B, em que havia esse profissional, todas as orientações e respostas das dificuldades técnicas e operacionais 
eram discutidas diariamente, facilitando as atividades de controle. Além disso, a própria relação da empresa executante com os usuários do prédio era mais eficiente, pois as necessidades surgidas podiam ser discutidas e, se fosse o caso, imediatamente sanadas.

No Edf. A havia ainda no condomínio a presença constante de um profissional responsável pela sua administração, o que facilitava bastante a tomada rápida de decisões, quando necessário. Nos demais casos, o contato da gerenciadora ocorria diretamente com o síndico, cujos níveis de exigência, disponibilidade de tempo e conhecimento técnico eram bastante diferenciados, apesar de serem todos engenheiros civis, porém não atuantes na área.

Também no caso do Edf. A após a saída da primeira empresa executante do serviço alguns dos seus funcionários impetraram ações na Justiça do Trabalho em favor dos seus direitos, contra a empresa e, de forma solidária, contra o condomínio. No momento da audiência os representantes da empresa não compareceram, de modo que o condomínio resolver quitar as despesas com os valores retidos dos pagamentos efetuados ao longo da obra. Com isso, o condomínio não teve nenhum prejuízo financeiro relacionado com esse problema.

Com base nas informações descritas nos itens anteriores é apresentada a Tabela 7, na qual são apresentados alguns dos fatores que podem ter contribuído de forma positiva e negativa durante a condução dos serviços.

Tabela 7 - Discussão da origem de fatores de sucesso (e insucesso) relevantes observados nas obras em estudo (I - Avaliação das necessidades do prédio, II - Aspectos de contrato (a - projeto executivo, b - questões financeiras, c - questões técnicas, d - questões operacionais), III - acompanhamento).

\begin{tabular}{|c|c|c|c|}
\hline Origem & Caso & Causa & Conseqüências \\
\hline \multicolumn{4}{|c|}{ Fatores de insucesso } \\
\hline 1 & A & Avaliação equivocada do problema. & Prazo e custo da obra maior que o previsto. \\
\hline II a & B & $\begin{array}{l}\text { Erro no levantamento das quantidades de } \\
\text { serviços. }\end{array}$ & Prazo e custo da obra maior que o previsto. \\
\hline II a & $A, B, C$ & $\begin{array}{c}\text { Previsão de prazos muito curtos, } \\
\text { insuficientes para uma adequada execução. }\end{array}$ & Atraso no prazo de execução das obras. \\
\hline II b & Todos & $\begin{array}{l}\text { Inexistência de sansões claras para o não } \\
\text { cumprimento dos prazos. }\end{array}$ & Atraso no prazo de execução das obras. \\
\hline II d & $\mathrm{C}$ & $\begin{array}{l}\text { Inexistência de exigência mínima de } \\
\text { equipamentos para o início dos serviços. }\end{array}$ & Atraso no prazo de execução da obra. \\
\hline
\end{tabular}




\begin{tabular}{c|c|c|c}
\hline II d & A & $\begin{array}{c}\text { Não houve registro das áreas vizinhas e } \\
\text { comuns antes do início da obra. }\end{array}$ & $\begin{array}{c}\text { Necessidade de limpeza da fachada do } \\
\text { edifício vizinho. }\end{array}$ \\
\hline III & A & $\begin{array}{c}\text { Pequena exigência de entrega das guias de } \\
\text { comprovação de pagamento das obrigações } \\
\text { trabalhistas. }\end{array}$ & $\begin{array}{c}\text { Ações na justiça impetradas pelos } \\
\text { funcionários no final da obra. }\end{array}$ \\
\hline
\end{tabular}

Fatores de sucesso

\begin{tabular}{|c|c|c|c|}
\hline 1 & B, C, D & $\begin{array}{l}\text { Atividades previstas não precisaram nenhum } \\
\text { tipo de alteração. }\end{array}$ & $\begin{array}{l}\text { Os serviços foram executados, em sua } \\
\text { totalidade, conforme previstos. }\end{array}$ \\
\hline II & Todos & $\begin{array}{l}\text { Alto nível de exigência apresentado no } \\
\text { documento enviado às empresas. }\end{array}$ & Pequeno número de empresas concorrentes. \\
\hline II a & Todos & $\begin{array}{l}\text { As planilhas básicas serviram, com erro de } \pm \\
25 \% \text {, como referência de preços. }\end{array}$ & $\begin{array}{c}\text { Adequação do custo inicial da obra ao } \\
\text { previsto pelo condomínio. }\end{array}$ \\
\hline II a & C & $\begin{array}{c}\text { Avaliação rigorosa prévia das quantidades de } \\
\text { serviços previstos. }\end{array}$ & Não ocorreram aditivos aos serviços. \\
\hline II c & B & $\begin{array}{l}\text { Presença continua de profissional } \\
\text { (encarregado) da empresa executante. }\end{array}$ & $\begin{array}{l}\text { Rápida tomada de decisão junto aos usuários } \\
\text { dos apartamentos. }\end{array}$ \\
\hline II d & Todos & $\begin{array}{l}\text { Explicitação clara das exigências de } \\
\text { segurança e higiene dos funcionários. }\end{array}$ & $\begin{array}{l}\text { As ocorrências foram sanadas sem maiores } \\
\text { repercussões. }\end{array}$ \\
\hline
\end{tabular}

Complementando os estudos apresentados, em pesquisa desenvolvida por Lordsleem Jr et al. (2007) foram discutidas observações realizadas em 5 obras de manutenção de fachada em condomínios executadas na cidade do Recife nos anos de 2006 e 2007. São obras com porte e características similares, nas quais se verificaram problemas diversos tanto de ordem técnica como operacional.

Dentre os aspectos operacionais, destaca-se a inexistência de sinalização, tapume e guarda corpo de segurança em nenhum dos casos estudados, assim como em 3 das 5 obras os operários não dispunham dos EPI's. Já quando às questões técnicas, foram constatadas diferenças notáveis de procedimentos executivos e materiais, como o tempo de utilização e de descanso da argamassa colante, o tipo de rejuntamento e a forma de limpeza final, que denotam deficiências relacionadas com a especificação ou com o controle.

Esses estudos servem para ratificar, em outros casos práticos, a vulnerabilidade a dificuldades de diversas ordens nesse tipo de obra quando a sua execução não é efetuada precedida pela implantação de um modelo de gestão voltado para o seu adequado desempenho técnico e operacional. 


\section{GESTÃO DE OBRAS DE MANUTENÇÃO EM FACHADA}

O objetivo do presente capítulo é discutir cientificamente, a partir de literatura técnica nacional e internacional, as ações consideradas importantes para a gestão das atividades de manutenção em revestimentos de fachada. Conforme já anteriormente descrito, em linhas gerais as ações propostas nesta tese são:

- Avaliação das necessidades de intervenção.

- Análise e critérios para seleção da empresa executante do serviço.

- Acompanhamento dos serviços.

Para uma melhor interpretação do conteúdo, a Tabela 8 apresenta uma descrição sumarizada das ações indicadas para o método inicial proposto. Ao longo do capítulo as ações propostas serão discutidas de forma detalhada, a partir de recomendações encontradas na literatura e de observações efetuadas pelo autor.

Para a validação das propostas todas essas ações foram formatadas como questionamentos (Página 134) a fim de serem apresentadas para análise dos especialistas, discutida nos Capítulos 5 e 6. Apenas após essa análise o conteúdo das propostas apresentadas pode ser considerado cientificamente aprovado, gerando o método final consolidado apresentado no item 6.3. 
Tabela 8 -Descrição da proposta inicial apresentada para a gestão das obras de manutenção em revestimentos de fachada.

\begin{tabular}{|c|c|c|}
\hline ETAPA & ATIVIDADES & FASES \\
\hline \multirow{3}{*}{$\begin{array}{l}\text { Avaliação das } \\
\text { necessidades de } \\
\text { intervenção }\end{array}$} & Diagnóstico do problema & $\begin{array}{c}\text { Vistoria } \rightarrow \text { descrição do edifício } \rightarrow \text { anamnese do problema } \rightarrow \text { realização de ensaios } \\
\text { (caso necessário) } \rightarrow \text { interpretação de resultados }\end{array}$ \\
\hline & Discussão de alternativas & Prognóstico de evolução $\rightarrow$ discussão de alternativas (vantagens e desvantagens) \\
\hline & Tomada de decisões & Levantamento estimativo de custos \\
\hline $\begin{array}{l}\text { Análise e critérios } \\
\text { para a contratação }\end{array}$ & Projeto do produto & $\begin{array}{c}\text { Planejamento dos serviços (equipamentos, prazos, mão de obra) } \rightarrow \text { especificação dos } \\
\text { materiais } \rightarrow \text { levantamento de quantitativos } \rightarrow \text { orçamento de referência. }\end{array}$ \\
\hline \multirow{2}{*}{$\begin{array}{c}\text { Acompanhamento } \\
\text { dos serviços }\end{array}$} & Questões técnicas & Aceitação e recebimento $\rightarrow$ produção $\rightarrow$ ensaios $\rightarrow$ termo de conclusão \\
\hline & Questões operacionais & Prazos e repercussões $\rightarrow$ problemas fiscais e trabalhistas $\rightarrow$ distúrbios diversos \\
\hline
\end{tabular}


A execução de obras de manutenção em edificações deve ser precedido por um adequado planejamento, que envolve o diagnóstico das intervenções necessárias e discussão das alternativas, seguido pelas atividades de seleção e contratação da empresa executante, e conduzido a partir de um acompanhamento das questões técnicas e operacionais envolvidas.

Importante aqui salientar que um bom planejamento não é garantia de redução de custos ou de prazos, mas auxilia na tomada de decisões. Porém, quanto maiores forem as indefinições durante a etapa de concepção dos serviços, maiores incertezas e, conseqüentemente, maiores prazos e custos. O bom planejamento pode até levar a uma queda dos custos, desde que atrelada a ações relacionadas ao processo de produção.

O ponto de partida para a execução de qualquer empreendimento é a definição do seu projeto, referência básica para o desenvolvimento das ações. Como lembra Kumar (2005), o termo projeto vem do latim "projicere", que denota ação precedente. Os projetos devem ser concebidos para atender às necessidades do seu solicitante, contemplando, para isso, especificações, detalhamentos, e definições do processo produtivo e das atividades de controle.

Os conceitos apresentados por Melhado (1998) para projeto estão descritos a seguir:

- Projeto do Produto (Projeto Executivo): envolve as especificações dos materiais, aspectos geométricos, tratamento dos prontos críticos (como a definição para colocação das juntas de movimentação e telas metálicas em revestimentos cerâmicos de fachada, por exemplo), todos suficientes para a elaboração do orçamento.

- Projeto do Processo: elaborado de maneira simultânea ao Projeto do Produto, contempla os procedimentos executivos, disposição e seqüência executiva das atividades da obra, detalhes operacionais, tais como equipamentos, arranjos e evolução do canteiro, e atividades de controle.

Para efeito do presente estudo, os projetos do produto e do processo serão tratados apenas pelo termo projeto, ampliando-se ainda para as ações de investigação das condições de conservação da edificação, análise de responsabilidades, e proposição de intervenções. 
Em face da complexidade envolvida na sua execução, as atividades de controle e acompanhamento serão tratadas à parte do projeto, uma vez que serão discutidas ações pontuais, diárias, e também de aspecto mais amplo, ou estratégico.

Interessante destacar que os projetos desenvolvidos nesse tipo de obra apresentam maiores dificuldades do que aqueles concebidos para obras novas, conforme salientado por Sanvido e Riggs (1993) em trabalho sobre práticas efetivas para a redução de problemas decorrentes das restrições existentes no gerenciamento de atividades de "retrofit" em edificações.

Attalla e Hegazy (2003) citam como fatores de sucesso para a etapa de projeto do gerenciamento da manutenção de edificações: plano de integração entre os agentes envolvidos; estrutura de custos bem definida; definição do "lay-out" da obra; análise da relação custo benefício das ações. Parker (1994) também destaca que o escopo de um projeto deve envolver elementos de custos e tempo, além de aspectos técnicos.

Assim, no caso das obras de manutenção, para efeito do presente estudo o projeto deve começar por uma atividade de extrema importância que é o diagnóstico das causas concorrentes para o problema. Afinal de contas, não adianta combater os efeitos sem o conhecimento dos prováveis elementos causadores, sob pena da solução adotada se tornar apenas um paliativo, demandando futuro retrabalho e aumento de custos.

\subsection{Avaliação das necessidades para intervenção}

\subsubsection{Diagnóstico das necessidades do prédio}

Para Perez (1988) o sucesso dos trabalhos de manutenção numa edificação está atrelado ao diagnóstico de cada falha encontrada, desde deterioração natural até problemas decorrentes do mau uso. Grilo e Calmon (2000) enfatizam que o estudo das falhas permite a adoção de práticas preventivas e corretivas desde o projeto, reduzindo, até mesmo, os custos com a manutenção.

Também o BRE (2001) destaca a importância da avaliação acurada das condições de conservação do edifício para a elaboração de um adequado programa de manutenção. A detecção prévia de falhas potenciais no prédio pode reduzir sensivelmente o custo da intervenção. 
Gaspar e Brito (2005) enfatizam que o adequado diagnóstico do estado de conservação dos elementos de fachada e o seu prognóstico de comportamento servem para auxiliar projetistas e usuários a conceber edificações e estratégias de manutenção que permitam incrementar a durabilidade desses componentes.

Assim, entende-se que o acerto na investigação da edificação é um elemento chave para a condução adequada dos serviços de manutenção, devendo-se, apenas após a definição das necessidades, buscar alternativas de intervenção o menos onerosas e traumáticas possíveis.

Vários autores nacionais e internacionais (GOMIDE, 2006; CAMPANTE, 2001; COSTA E SILVA, 2001; PETRUCCI et al., 1997; RUANO, 1997; TABORDA e SOEIRO, 1994; APPLETON e BAIÃO, 1994; FELIÚ et al., 1992) apresentam diferentes metodologias ${ }^{18}$ para inspeção em revestimentos de fachada. A inexistência de um padrão ou, ao menos, um modelo genérico consagrado para a condução desse tipo de trabalho dificulta a condução de estudos e pesquisas na área, uma vez que situações, muitas vezes semelhantes, são tratadas sob óticas e, principalmente, a partir de critérios de análise diferenciados, o que dificulta qualquer tipo de comparação.

A NBR 5674 (ABNT, 1999) recomenda a adoção de modelo para os relatórios de inspeção, a fim de facilitar o registro, documentação e recuperação de informações.

Conforme bem salienta Ruano (1997) a metodologia deve ser simples e de fácil adaptação às circunstâncias variáveis de cada caso, sem a qual o trabalho de diagnóstico torna-se caótico e desordenado e as possibilidades de acerto são reduzidas.

Appleton e Baião (1994) enfatizam a importância de uma metodologia de diagnóstico para sistematizar as ações de intervenção e a tomada de decisões, possibilitando a sua reaplicação, com racionalização dos meios disponíveis e otimização dos resultados.

Barrientos e Qualharini (2004) apresentam técnica para definição das intervenções de "retrofit" em edificações baseada no desenvolvimento das seguintes atividades: vistoria,

\footnotetext{
${ }^{18}$ Ruano (1997) conceitua metodologia de investigação como um conjunto de princípios, categorias e
} leis de diferentes níveis que permite orientar os esforços de investigação para o conhecimento da verdade objetiva com o máximo de eficiência. 
pesquisa documental, questionário e entrevistas com os usuários, medições físicas e investigações complementares (realização de ensaios específicos).

No presente estudo, a linha geral adotada para a investigação prevê a adoção dos passos representados de forma gráfica na Figura 4, cujas principais considerações são abordadas ao longo dos próximos tópicos do texto. Importante ressaltar que não se trata do escopo do presente trabalho explorar as formas de análises de diagnóstico de manifestações patológicas em fachada, que já foi exaustivamente discutido e apresentado por outros pesquisadores, cabendo aqui apenas alguns comentários julgados importantes.
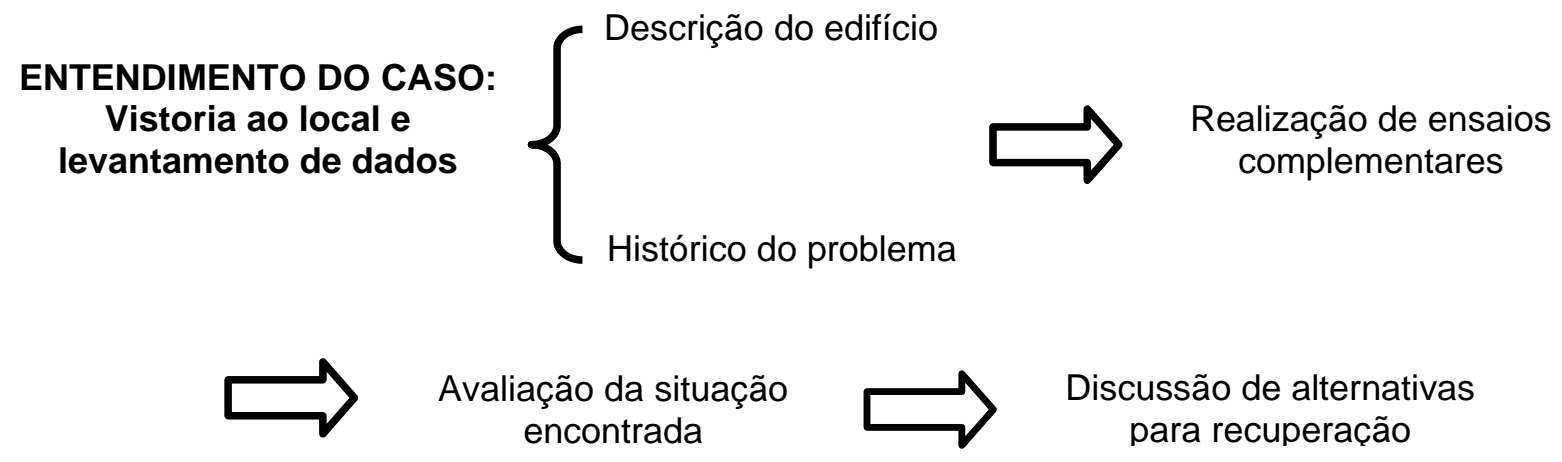

Figura 4 - Descrição das ações tomadas durante o diagnóstico das necessidades do prédio.

Em todos os casos, porém, propõe-se que a execução dessa atividade seja efetuada por um profissional de reconhecida capacidade e experiência, dada a imperativa necessidade de acerto para possibilitar o sucesso da obra.

\subsubsection{Descrição do edifício e anamnese do problema}

Trata-se da etapa inicial de avaliação do problema, momento em que o profissional busca o maior número possível de dados a respeito do prédio, idade, tipo de solução estrutural, posicionamento das fachadas em relação à incidência solar, chuva e ventos predominantes, materiais e procedimentos executivos adotados à época da construção etc.

Todo tipo de informação coletada a respeito do edifício é importante, pois pode servir como peça auxiliar para a elucidação do problema, ou das condições existentes para a intervenção. Por isso, a experiência do profissional ajuda também na identificação de pessoas envolvidas durante e após a conclusão da obra (construtora, operários, fiscalizadora). Informações colhidas junto aos usuários podem também servir como mais um 
dado relevante na investigação, cabendo ao avaliador, entretanto, a filtragem das afirmações que podem ser consideradas verdadeiras e significativas para cada caso.

Para Casimir (1994), a simples atividade inicial de inspeção visual pode prover a etapa de investigação de informações diversas a respeito do caso que, quando adequadamente analisadas, e em conjunto, irão conduzir as fases posteriores de estudo. Esse autor salienta também a importância da experiência do avaliador para a correta condução das investigações, opinião corroborada ainda por Appleton e Baião (1994).

A necessidade de se ter um profissional qualificado, capaz de identificar as falhas e as respectivas necessidades de intervenção, também está destacada no BRE (2001), especialmente por se tratar de uma atividade muito especializada.

Reforçando a necessidade de experiência do profissional envolvido na investigação inicial, Alani; Petesen e Chapman (2001) apresentam caso em que as condições do revestimento recém recuperado da parede encobriram a real situação em que se encontrava a base, dificultando a análise precisa do conjunto.

A anamnese contempla a investigação detalhada das circunstâncias que cercam os problemas encontrados ou o histórico das condições de uso do prédio. Com isso, a partir de vistorias realizadas ao imóvel é efetuada análise para identificação de informações essenciais como condições de execução na época da obra, tempo de ocorrência dos eventuais problemas e locais predominantes, atividades de manutenção executadas, processo evolutivo, entre outros. Novamente aqui é importante a obtenção do maior número possível de informações.

Em artigo publicado por Matos e Lima (2006) foram discutidos os fatores ambientais de degradação de fachadas, dentre os quais se destacam as variações térmicas, o efeito do vento e das chuvas e as contaminações. Com isso, a depender da posição do pano na fachada, os citados fatores atuam com diferentes intensidades, originando níveis de degradação variados para cada situação, o que justifica uma análise minuciosa desses efeitos para a obtenção de um adequado diagnóstico das necessidades do prédio.

A fim de prover de informações o avaliador, Barrientos e Qualharini (2004) descrevem a atividade de pesquisa documental referente à coleta dos diversos projetos disponíveis (arquitetura, estrutura, instalações) para identificação de informações do imóvel, 
condições legais, e até mesmo datas que possam auxiliar na investigação das tendências da época ou junto ao construtor da obra. Esses autores sugerem ainda a realização de questionários e entrevistas com os usuários na tentativa da coleta de informações eventualmente não contidas nos documentos. Nesse aspecto, cabe destacar também a vertente de satisfação proporcionada ao cliente (usuário) de ter as suas idéias ou comentários levados em conta durante o desenvolvimento do diagnóstico.

Interessante notar que o item 7.2.b da NBR 5674 (ABNT, 1999) salienta que o condomínio deve possuir estrutura de documentação com registro de serviços de manutenção realizados na edificação.

Instrumento utilizado para auxiliar na interpretação do estado de conservação dos elementos da fachada é a projeção esquemática em planta dos locais principais de incidência de problemas, o que possibilita uma avaliação mais ampla do caso.

Em trabalho apresentado por Gaspar e Brito (2005) é descrita metodologia por meio de mapeamento de defeitos em fachadas revestidas com argamassas associando nível de degradação e número de ocorrência, com base em pesquisa realizada em 150 prédios em Portugal. A fachada é dividida em 6 áreas distintas (paredes contínuas, quinas, platibanda, sacadas, periferias das aberturas e regiões próximas ao piso), que são mapeadas e expressas graficamente (similar a curvas de nível - Figura 5) com valores que representam, nas curvas internas, a probabilidade de ocorrência de defeitos, e no lado direito o nível de degradação, de 0 a 4. Com isso, é possível até inferir na probabilidade de ocorrência futura de problemas. 


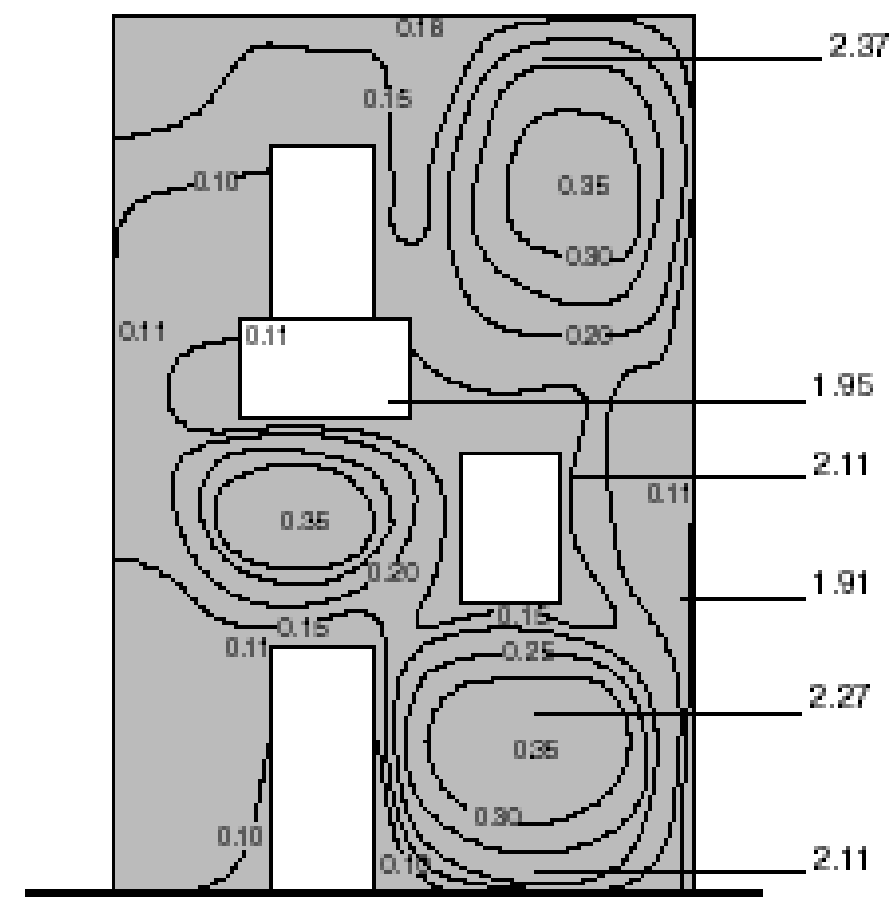

Figura 5 - Esquema de representação de graus de deterioração na fachada apresentado por Gaspar, Brito (2005).

Petrucci et al. (1997) publicaram estudo de aplicação prática para levantamento de manifestações patológicas nas fachadas de 20 blocos residenciais localizados na cidade de Porto Alegre. Os problemas foram mapeados e apresentados por meio de desenhos nos quais as fachadas se encontravam desenhadas em escala e desdobradas num mesmo plano. Como as fachadas estavam ainda divididas por áreas, com base no levantamento foi possível até quantificar de forma estimativa a extensão dos danos encontrados. Essa técnica serviu também como base para a descrição dos casos estudados na pesquisa desenvolvida por Costa e Silva (2001), conforme se pode observar na Figura 6.

Apesar de parecer evidente, Barrientos e Qualharini (2004) relacionam, dentre os materiais básicos para a etapa de vistoria, a utilização equipamentos para levantamento das dimensões, medição dos ventos dominantes e do imóvel em relação aos pontos cardeais, além de máquinas fotográficas e filmadoras, com boa capacidade de angular para permitir o registro e documentação das informações relevantes. 


\begin{tabular}{|c|c|c|c|c|}
\hline \multicolumn{5}{|c|}{ CASO E } \\
\hline PANOS & $\begin{array}{l}\text { AREA TOTAL } \\
\text { DE FACHADA }\end{array}$ & \begin{tabular}{|l|} 
AREA DE \\
DESCOLAMENTO
\end{tabular} & $\begin{array}{l}\text { AREA } \\
\text { UTIL }\end{array}$ & POSICIONAMENTO \\
\hline P1 & $214.26 \mathrm{~m}^{2}$ & & $91.16 \mathrm{~m}^{2}$ & LESTE \\
\hline P2 & $81.69 \mathrm{~m}^{2}$ & & $70.09 \mathrm{~m}^{2}$ & LESTE \\
\hline P3 & $85.18 \mathrm{~m}^{2}$ & & $85.18 \mathrm{~m}^{2}$ & SUL \\
\hline P4 & $288.51 \mathrm{~m}^{2}$ & $0.78 \mathrm{~m}^{2}$ & $245.41 \mathrm{~m}^{2}$ & SUL \\
\hline P5 & $162.58 \mathrm{~m}^{2}$ & $2.41 \mathrm{~m}^{2}$ & $88.88 \mathrm{~m}^{2}$ & OESTE \\
\hline P6 & $104.49 \mathrm{~m}^{2}$ & & $104.49 \mathrm{~m}^{2}$ & SUL \\
\hline P7 & $87.74 \mathrm{~m}^{2}$ & $7.74 \mathrm{~m}^{2}$ & $83.14 \mathrm{~m}^{2}$ & OESTE \\
\hline P8 & $104.49 \mathrm{~m}^{2}$ & & $104.49 \mathrm{~m}^{2}$ & NORTE \\
\hline P9 & $162.38 \mathrm{~m}^{2}$ & $0.37 \mathrm{~m}^{2}$ & $88.88 \mathrm{~m}^{2}$ & OESTE \\
\hline P10 & $288.51 \mathrm{~m}^{2}$ & & $245.41 \mathrm{~m}^{2}$ & NORTE \\
\hline P11 & $85.18 \mathrm{~m}^{2}$ & & $85.18 \mathrm{~m}^{2}$ & NORTE \\
\hline $\mathrm{P} 12$ & $81.69 \mathrm{~m}^{2}$ & & $70.09 \mathrm{~m}^{2}$ & LESTE \\
\hline TOTAL & $1747 \mathrm{~m}^{2}$ & $11.3 \mathrm{~m}^{2}$ & $1362 \mathrm{~m}^{2}$ & \\
\hline
\end{tabular}
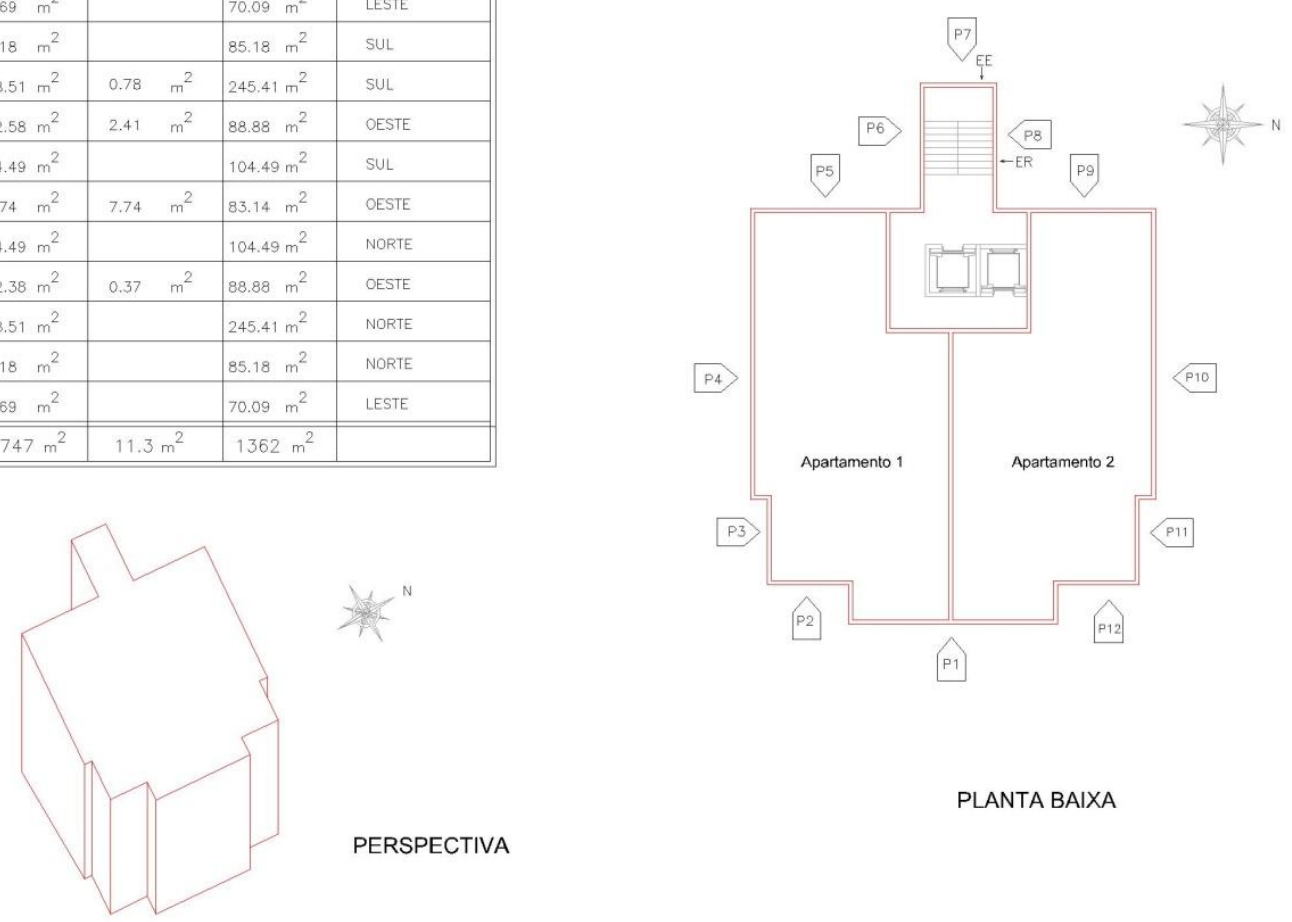

PERSPECTIVA

PLANTA BAIXA

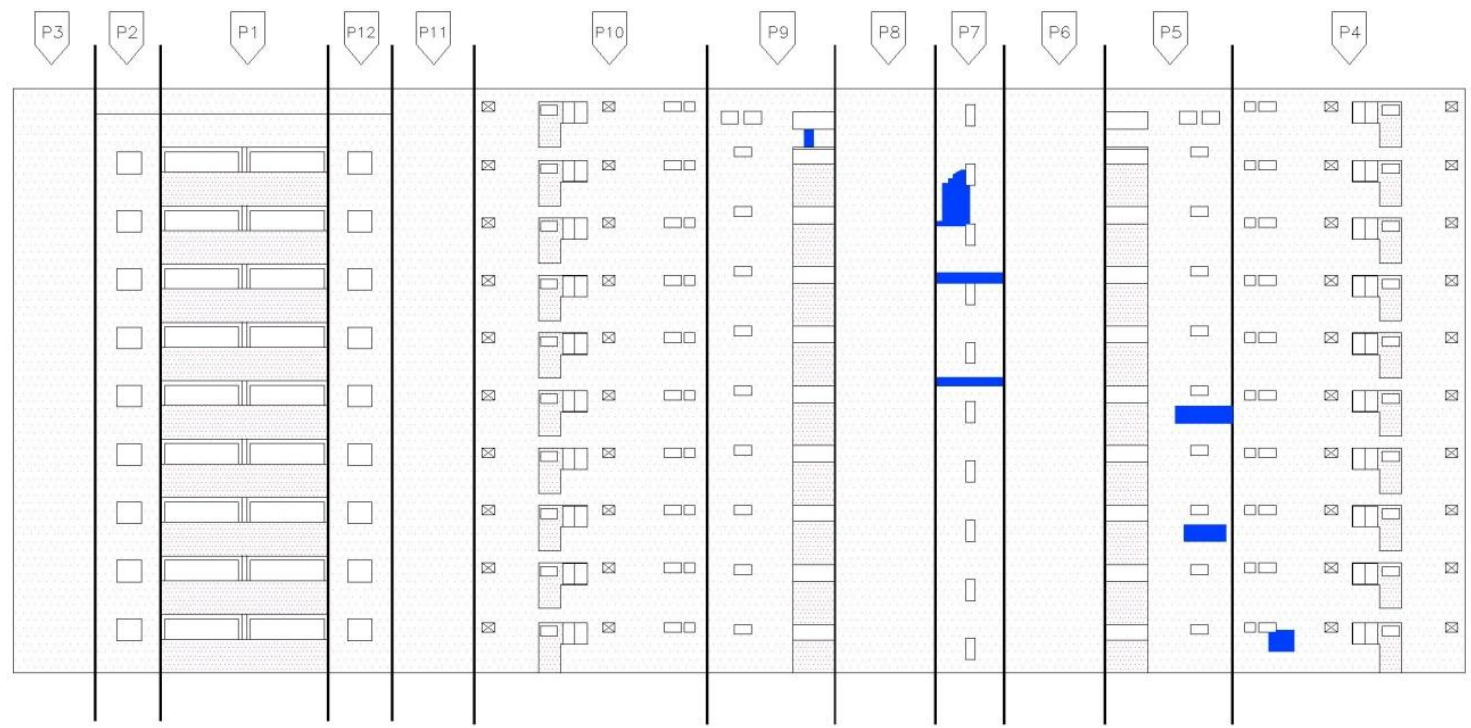

Cerâmica bege clara

Figura 6 - Descrição de áreas de descolamento de revestimento de fachada (Costa e Silva, 2001). 
Nessa etapa cabe ao profissional responsável pelo diagnóstico avaliar o grau de aprofundamento necessário da investigação para obtenção de dados seguros e confiáveis para a definição das reais necessidades de intervenção.

\subsubsection{Ensaios e avaliações laboratoriais}

A realização de ensaios de caracterização, em muitos dos casos, é um meio imprescindível para a definição das etapas e procedimentos executivos. A maior dificuldade encontrada nesta etapa é a definição precisa a respeito de quais avaliações poderão conduzir a respostas claras para o problema, bem como a sua magnitude e confiabilidade.

Segundo Ruano (1997), a realização de ensaios surge quando a intervenção a ser realizada decorre de uma problema cujo avaliador julga se tratar de uma investigação científica, que ultrapassa os seus conhecimentos mínimos necessários para prescindir dessa etapa.

Barrientos e Qualharini (2004) enfatizam que a realização de ensaios é necessária quando se precisa fazer uma avaliação mais apurada a respeito do desempenho dos componentes. Esses autores salientam ainda a importância da experiência e bom senso do profissional avaliador para ponderar e eleger os ensaios necessários e suficientes para a obtenção das respostas para a solução do caso, uma vez que tais atividades demandam custos.

Nos casos de descolamentos de revestimentos aderidos (argamassas, placas cerâmicas e de rocha), por exemplo, o teste mais comumente utilizado "in loco" é o ensaio de resistência de aderência à tração direta, cujos métodos de ensaio e critérios mínimos de aceitação são claramente definidos, respectivamente, pela NBR 13528 (ABNT, 1995b) e pela NBR 13749 (ABNT, 1996) $)^{19}$.

Nesse caso, uma correta avaliação deve contemplar a realização de ensaios em pontos aleatórios e espalhados ao longo dos pavimentos na fachada, a fim de se obter análises nas mais diferentes condições de solicitação.

\footnotetext{
${ }^{19}$ Outros comentários sobre o ensaio resistência de aderência à tração direta são apresentados no
} item 4.3.1.2. 
Ainda no campo dos revestimentos aderidos, outro instrumento interessante é a inspeção por percussão para identificação de regiões ou placas com som cavo. Goldberg (1998) afirma que, a partir da nitidez e freqüência do som obtido na percussão é possível se há falha no revestimento. Casimir (1994), porém, ao enfatizar esse tipo de investigação, salienta que em alguns casos as placas cerâmicas podem estar descoladas sem, no entanto, desprenderem da base, o que pode "falsear" a análise. De todo modo, análises totais ou amostrais em determinados trechos da fachada podem fornecer informações estimativas interessantes a respeito da aderência entre os componentes.

Existem ainda equipamentos não destrutivos utilizados para investigação analógica da integridade de revestimentos por meio da transmissão e reflexão de ondas, ainda carentes de estudos específicos que possam assegurar a eficiência da sua utilização para investigação de problemas de descolamento em fachadas.

Outros ensaios de caracterização também podem ser realizados, de acordo com a situação encontrada no prédio. Em todos os casos, entretanto, é fundamental a correta definição do avaliador a respeito da quantidade de amostras ensaiadas e do local, ou corpode-prova, tomado como representativo do todo. Uma má escolha nesta fase pode conduzir a erros de interpretação e análise.

Em todos os casos é importante considerar a necessidade quase imperativa de instalação de uma infra-estrutura mínima para investigação de problemas em fachadas, que podem ir desde equipamentos individuais, tipo cadeiras, até balancins mais robustos e rápidos, como plataformas móveis.

\subsubsection{Interpretação dos resultados}

Uma vez concluídos os ensaios é necessário interpretá-los de forma eficiente e confiável. Quando possível, a comparação dos valores encontrados com critérios mínimos estabelecidos na normalização é o mecanismo mais claro e imediato de análise, cujas repercussões têm respaldo técnico e legal.

Em algumas situações, entretanto, apenas a análise da normalização pode não ser suficiente, exigindo uma investigação coordenada entre os ensaios e os dados encontrados na anamnese e descrição do edifício. 
É de responsabilidade do profissional avaliador saber identificar eventuais distorções que possam surgir nos resultados encontrados em função de deficiências de ensaio (falta de calibração de equipamentos, imprecisão) ou de amostragem.

Não são raras as situações em que o avaliador se vê obrigado a lançar mão de novos ensaios, ou repetir os primeiros, para confirmação dos valores encontrados.

\subsubsection{Avaliação da situação encontrada / Diagnóstico das causas prováveis}

Com base em todos os dados colhidos ao longo do trabalho de investigação é possível inferir algumas causas que possam estar contribuindo para o problema. Importante destacar que há sempre uma combinação de causas oriundas de diferentes origens participando do fenômeno.

Essa afirmação é corroborada por diversos pesquisadores atuantes na área de patologia das construções em suas várias especialidades. Existe um senso comum de que as origens para a ocorrência dos problemas estão associadas às etapas de planejamento (projeto), especificação dos materiais, execução, e uso e manutenção (ISAIA, 2005; COSTA E SILVA, 2001; CASIMIR, 1994; PEREZ, 1988; LEE, 1987).

A comparação com outros casos similares ocorridos e apresentados em literatura técnica, cujos dados podem ser considerados confiáveis, auxilia também na descrição das causas concorrentes.

Nos casos em que o cliente final, ou solicitante do serviço, não seja um especialista, é interessante que seja adotada uma linguagem simples e clara, com explicação técnica sucinta dos fatores de influência e identificação de pontos críticos.

\subsubsection{Avaliação de responsabilidades}

Invariavelmente polêmica no estudo de problemas ocorridos em edificações é a questão da definição de responsabilidades entre construtores, fornecedores de materiais e usuários. 
A exigência de conhecimento técnico específico para o diagnóstico das causas, associada a análises de códigos e leis jurídicas, conduz a uma complicada rede de interpretações cujas conclusões são bastante casuísticas, na maioria das vezes.

A despeito disso, a condução de uma atividade de manutenção pode estar muito atrelada à definição da responsabilidade, a quem poderá caber o seu ônus.

Evidente que as questões técnicas relacionadas com as atividades de manutenção devem estar à parte da discussão acerca dos culpados, entretanto o agente responsável pelo investimento de capital pode conduzir as atividades conforme as suas necessidades e disponibilidade.

Sob o ponto de vista legal, a análise de responsabilidades é efetuada a partir das normas constantes do Código Civil Brasileiro (promulgado em janeiro de 2002 e em vigor desde janeiro de 2003) e no Código de Defesa do Consumidor (CDC - Lei 8.078, de 11.09.90), objetos das diversas interpretações doutrinárias existentes.

O artigo 1245 do Código Civil dispõe claramente que o construtor responde, durante cinco anos, pela solidez e segurança do imóvel. Entretanto, conforme apresentam Tôrres e Pinto (2000), a atual interpretação para esse artigo amplia o conceito de solidez e segurança a defeitos diversos de construção, que impeçam ou dificultem o uso do imóvel.

Com relação ao tempo de 5 (cinco) anos, esse prazo se refere à garantia do imóvel, e não à prescrição do direito ${ }^{20}$. Isto é, ao condomínio é reservado o direito de acionar a construtora por defeitos surgidos na edificação nos 5 anos seguintes ao término da construção, durante um prazo de 20 anos, quando, enfim, o mesmo é prescrito.

O CDC apresenta ainda distinção entre vício aparente, de imediata visualização e fácil constatação, e vício oculto, cuja detecção exige conhecimento técnico especializado. Para os problemas de vício oculto, existe um prazo de 90 dias para reclamação, iniciado apenas após ficar evidenciado o defeito.

${ }^{20}$ Conforme Grandiski (2002), a prescrição implica na perda do direito a uma ação judicial, enquanto a decadência (ou caducidade) é a perda ou extinção do direito em si.

4. GESTÃO DE OBRAS DE MANUTENÇÃO EM FACHADA 
Grandiski (2002), citando o CDC em uma visão ainda mais ampla, apresenta distinção entre os conceitos de vício, cuja ocorrência afeta "apenas" o bolso do consumidor, e defeito, que afeta (ou representa ameaça potencial) a saúde ou segurança do consumidor.

Interessante comentar que o CDC veda qualquer tipo de cláusula contratual que atenue ou extingue a responsabilidade do construtor, de modo que não é possível a transferência de responsabilidade da manutenção para o usuário por meio do manual de operação, uso e manutenção.

A norma brasileira que discute o conteúdo desses manuais, a NBR 14037 (ABNT, 1998), enfatiza a necessidade que esse documento seja elaborado com linguagem simples, direta, organizada, destacando itens que tratem da segurança e estabilidade da edificação. Devem constar do manual, além das questões de operação, uso e manutenção (tais como freqüência de inspeções, procedimentos, especificações), instruções sobre garantias e responsabilidades, procedimentos para situações de emergência, entre outros.

Para essa situação, os serviços de fachada normalmente descritos no manual tratam de limpeza geral, inspeção para identificação de eventuais pontos deficientes de aderência, substituição de componentes cuja vida útil seja mais reduzida que da própria fachada. Exemplo disso são os mastiques elásticos utilizados em juntas de movimentação para revestimentos cerâmicos de fachada, por exemplo, também atestado no BRE (2001).

O CDC (artigo 12) responsabiliza o construtor por informações insuficientes ou inadequadas sobre a utilização e riscos do imóvel. Assim, conforme afirmam Santos e Schmitt (2004) segundo o CDC a informação é um dever essencial básico, e a sua falta é considerado um defeito (extrínseco), tal como são os defeitos ou falhas construtivas (intrínsecos).

Segundo Santos e Schmitt (2004), pelo CDC, caso forneça o manual da edificação, o construtor se isenta de culpa caso o consumidor utilize de forma inadequada o imóvel, desde que prove alguma das três condições: não colocou o produto no mercado; mesmo o tendo colocado no mercado, o defeito não existe; a culpa é exclusiva do consumidor ou de terceiro (não inclui fornecedor de algum material à obra).

No aspecto da responsabilidade, a NBR 14037 (ABNT, 1998) explicita de forma clara alguns itens observados a respeito do manual, conforme se segue: 
- A elaboração do manual é uma obrigação do responsável pela produção da edificação, e deve ser entregue formalmente ao primeiro proprietário.

- Deve constar a identificação dos fornecedores diversos, incluindo dados para eventuais contatos, com a obrigatória ressalva que esse contato direto é uma faculdade do usuário, não uma responsabilidade.

- Descrição das garantias, prazos de validade e responsabilidades dos usuários para a validade dessas garantias também devem estar explícitos.

Importante ressaltar, conforme observam Santos e Schmitt (2004), que, segundo o CDC, a entrega do manual ao proprietário por parte do construtor é obrigatória. A despeito disso, esses autores reforçam a importância da adequada elaboração e aplicação do manual para redução dos custos pós ocupação, podendo servir, inclusive, como um instrumento de proteção para as construtoras.

Contudo, em face dessa falta de cultura de desenvolvimento de serviços de manutenção, as próprias empresas ainda têm dificuldades para elaboração desse documento. Pesquisa desenvolvida com usuários e construtores a respeito desses manuais, apresentada por Aguilera e Novaes (2004), indica que os conteúdos não suprem as necessidades dos usuários, e as empresas sentem falta de textos de referência que possam auxiliar na sua elaboração.

Outra pesquisa, realizada junto a 27 empresas dos Estados do Rio Grande do Sul e Alagoas e apresentada por Santos e Schmitt (2004), comprovou a ineficiência dos manuais produzidos, observando-se falhas na sua elaboração, como a inexistência de procedimentos para inspeção, tabelas de revisões, e, principalmente, certo descaso dos próprios usuários, refletido pela não entrega do documento pelos primeiros moradores aos subseqüentes. Além disso, foram citadas situações em que os usuários buscaram as informações no manual e, como não encontraram respostas adequadas, foram direto à construtora, evidenciando as deficiências existentes nesses manuais.

Voltando à questão das responsabilidades, cabe ainda comentar que, no caso de edificações, as causas para a ocorrência do problema assumem entre si uma relação de difícil interpretação quanto à parcela contribuinte de cada uma. Conforme salientado por 
Taborda e Soeiro (1994), as causas para os problemas ocorrem em número elevado, muitas vezes independentes, e de difícil quantificação.

É o que se entende na ciência jurídica por "causas concorrentes", cujas importâncias relativas não são passíveis de determinação, uma vez que não se conseguem reproduzir, em condições reais, protótipos das amostras defeituosas sem alguns dos seus componentes considerados como causas, a fim de permitir uma avaliação da ocorrência ou extensão do problema.

\subsubsection{Alternativas de intervenção e tomada de decisão}

Conhecidos os fatores intervenientes no caso, bem como os agentes envolvidos, fazse necessária a análise de alternativas disponíveis, incluindo vantagens e desvantagens, que servirão como referência para a tomada de decisão.

Nas obras de manutenção em fachada, as alternativas disponíveis para recuperação podem ser desde intervenções parciais localizadas até uma completa remodelagem estética ("retrofit" ${ }^{21 ")}$.

Barrientos e Qualharini (2004) entendem o "retrofit" como o processo de modernização e atualização de edificações antigas como forma de valorização por meio da incorporação de avanços tecnológicos (conforto, funcionalidade), levando em conta ainda a inserção do "novo" imóvel no ambiente urbano.

Abordagem interessante apresentada por Ruano (1997) enfatiza que toda intervenção deve ser precedida não apenas dos aspectos técnicos, mas também da história da edificação, a sua importância urbana no entorno, o uso, enfim, aspectos relacionados com a valoração histórica do imóvel. Esse autor afirma ainda que, como resultado do

${ }^{21}$ Trabalho apresentado por Barrientos e Qualharini (2004) indica as três seguintes possibilidades de intervenção para o "retrofit": a) derrubar e construir nova unidade, ou seja, não viabilidade técnica ou financeira para qualquer tipo de reabilitação; b) recuperar e realizar obras de menor porte visando adequação dos imóveis às novas necessidades ou utilizações; c) acrescentar elementos de conforto, quando o objetivo principal da intervenção é melhorar as condições de utilização. Esses autores apresentam ainda abordagem interessante para o "retrofit" associando a idéia de adaptação e ajuste da edificação às necessidades presentes com o enfoque de reabilitação também do ambiente urbano em que a mesma esteja inserida. 
trabalho de investigação, devem ser apresentadas alternativas de intervenção contemplando a urgência de cada caso, ou necessidades de intervenção a curto, médio ou longo prazo.

Aspectos como a conjuntura econômica, o local e tipo de empreendimento e a valorização comercial são fatores que podem levar os agentes envolvidos a levantar alternativas das mais diversas na busca do seu melhor interesse. Trabalho apresentado por Zelouf (1992), por exemplo, descreve proposição matemática para definir a melhor solução entre demolir e reconstruir ou renovar edificações públicas localizadas nos Estados Unidos, a partir de parâmetros como valor presente do bem, custos de renovação e valor equivalente funcional.

Lichtenstein (1985) destaca que o fim da vida útil de um edifício pode ser definido, ente outras formas, quando o mesmo passa a ter uma obsolescência funcional, momento em que a sua remodelagem ou atualização às necessidades e exigências do usuário são imprescindíveis.

Como bem afirmam Barrientos e Qualharini (2004), intervenções mal planejadas podem ser piores até do que a falta de manutenção.

Um dos problemas encontrados nessa etapa de decisão, em grande parte dos casos, é a falta de conhecimento dos agentes envolvidos, especialmente os usuários e os administradores de condomínios. Em geral são pessoas com perfil gerencial, porém deficientes sob o ponto de vista técnico necessário para o desenvolvimento do serviço.

No trabalho apresentado por Oliveira et al. (2006) em pesquisa realizada junto a síndicos verifica-se um elevado percentual de respostas afirmativas (75\%) quando questionados quanto à realização de obras de manutenção preventiva nas suas edificações, entretanto tais atividades se resumiam a pequenos consertos ou reparos localizados, muito distante do que se preconiza como ideal para evitar uma queda funcional de desempenho dos elementos da fachada.

O elemento chave para essa atividade é uma acertada discussão a respeito da evolução das condições de conservação do prédio ao longo dos tempos, ou seja, o seu prognóstico. Esse estudo permitirá ao agente investidor, no caso os proprietários dos 
imóveis, inferir a respeito das conseqüências das suas ações (ou omissões) durante a condução do caso.

O prognóstico deve ser elaborado a partir do estudo das causas concorrentes para o problema, se for o caso, em associação com casos similares descritos na literatura, na experiência do profissional, e também na evolução do quadro verificado na própria edificação.

Na Tabela 9, apresentada por Barrientos e Qualharini (2004) citando o método de análise europeu conhecido como EPIQR ${ }^{22}$, observa-se uma classificação dos elementos construtivos e as respectivas ações sugeridas para a intervenção a partir do estado de conservação do bem, que pode ser aplicado para a adequada tomada de decisão.

Tabela 9 - Classificação dos elementos construtivos (Barrientos e Qualharini, 2004).

\begin{tabular}{c|c|c|c}
\hline CÓDIGO & ESTADO & URGÊNCIA & AÇÃo \\
\hline A & Bom estado & Conservação & Manutenção \\
\hline B & Ligeira deterioração & Vigilância & Média reparação \\
\hline C & Média degradação & Intervenção & Substituição \\
\hline D & Fim da vida útil & Intervenção imediata & \\
\hline Para cada caso devem ser expressamente apresentadas aos condôminos as
\end{tabular}
vantagens e desvantagens envolvidas, como se segue:

- Previsão geral de custos, mesmo que apenas uma estimativa de custos por unidade de medida (metro quadrado), para balizar as ações.

- Prazo previsto para execução dos serviços.

- Garantias oferecidas pelos agentes construtores.

- Transtornos operacionais e funcionais para os usuários durante a execução dos serviços.

22 EPIQR (Energy Performance and Indoor Environmental Quality Retrofit) é uma metodologia européia desenvolvida para ajudar arquitetos e engenheiros atuantes na área de reforma de edificações, com o objetivo de avaliar de maneira estimativa os custos envolvidos para o incremento do desempenho energético e ambiental dos elementos de edificações já construídas (informações mais detalhadas podem ser obtidas em <http://www.epiqr.ch>. Acesso em 10 jan. 2008). 
- Análise dos riscos quanto à solução técnica adotada.

- Discussão do nível e periodicidade de manutenção futura a ser realizada na edificação.

- Possibilidade de valorização estética, comercial e até funcional do imóvel, se for o caso.

Assim, conforme já anteriormente discutido neste trabalho, e também destacado por Oliveira et al. (2006), o processo de decisão envolve aspectos técnicos (atividades indicadas, riscos envolvidos) e questões políticas (ou pessoais), de ordem operacional, que contemplam, entre outros, os níveis de responsabilidades dessas decisões.

Em concordância com o que foi discutido no início desse trabalho, não se pode esquecer de contemplar no levantamento dos custos para a obra os valores referentes às atividades de operação e manutenção da edificação que serão necessários a partir da conclusão da intervenção (PEREZ, 1988).

No momento da discussão das alternativas disponíveis para a execução da intervenção, tornam-se evidentes as vantagens obtidas quando os projetos executivos originais dos prédios foram contemplados com os conceitos de manutenabilidade. Nesses casos foram elaboradas concepções de modo que a conservação dos seus elementos pode ocorrer da forma menos onerosa e traumática possível, garantidas, naturalmente, as condições de conforto e habitabilidade.

A partir da apresentação das alternativas e suas respectivas repercussões é importante que o condomínio avalie as informações e decida pela opção que the for mais conveniente sob os aspectos técnico e operacional, aí incluídas, naturalmente, as questões de ordem financeira.

É natural que surjam dúvidas e questionamentos ao longo desta tomada de decisões que podem alterar o rumo das atividades previstas. Essas alterações propostas pelos próprios condôminos devem ser avaliadas em associação com as questões técnicas a fim de se assegurar o atendimento básico da intervenção a ser realizada, que é a solução de um problema instalado. 
Após a escolha final da alternativa é importante a documentação da decisão para ratificação das condições intrínsecas relacionadas com a atividade, e definição das ações para a etapa seguinte de contratação dos serviços.

Importante destacar que, segundo explicita a NBR 14037 (ABNT, 1998), as intervenções ou modificações à edificação em relação à original, devem, obrigatoriamente, gerar uma atualização no manual de operação, uso e manutenção, ação cujo responsável é o condomínio. Entretanto, por se tratar de uma atividade de cunho técnico, é recomendável que essa atualização seja elaborada pela empresa responsável pela execução dos serviços. 


\subsection{Análise e critérios para a contratação}

Concluída a investigação das necessidades de intervenção da edificação, pode-se partir para a análise e definição de critérios exigidos para a contratação dos serviços para execução da obra. Nesse tópico são discutidos os aspectos relacionados com o projeto do produto, que envolve programação, orçamento e levantamento dos custos, e os procedimentos efetivos para seleção e escolha da empresa executante do serviço.

\subsubsection{Projeto do produto}

\subsubsection{Programação dos serviços}

Dentro das atividades de planejamento de um serviço, entende-se a etapa de programação como a introdução da variável tempo, imprescindível para a avaliação do desenvolvimento de qualquer tipo de obra, e em especial no caso de edificações habilitadas ou em uso. Pesquisa realizada por Gao et al. (2002) aponta a correta programação e orçamento da obra como elementos decisivos para o sucesso do empreendimento.

Nas obras de manutenção de fachadas, a programação das atividades tem uma função operacional significativa, uma vez que define o momento ideal para aquisição de materiais e aluguel de equipamentos (se for o caso), previsão de interdição de áreas comuns e possibilita, até mesmo, a investigação do período mais apropriado para o início dos serviços, com base nas condições ambientais esperadas.

Entretanto, é importante frisar que uma boa programação dos serviços não é sinônimo de redução dos prazos de execução, que depende, principalmente, de decisões coordenadas e estratégicas entre as diversas fases do planejamento. Ao contrário, a depender do tipo de contrato, uma adequada programação pode até servir para estender o prazo de execução dos serviços (e também os seus custos), para possibilitar a liberação de recursos de acordo com a disponibilidade financeira do investidor ou proprietário.

Evidente que, quanto menor o prazo de execução da obra, menores serão os transtornos causados, porém se faz necessária uma avaliação das necessidades técnicas com as condições financeiras. Não são raros os casos em que o condomínio, a partir do custo e do prazo previsto para a execução da obra, prefere postergar o início dos serviços a fim de se capitalizar e, com isso, possibilitar a execução das atividades no prazo mais exíguo possível. 
Como aborda Kumar (2005), o controle das atividades e prazos envolve o uso eficiente da programação no sentido de facilitar o planejamento, a execução, a medição, e possibilitar ainda a realização de intervenções durante a evolução dos serviços.

Segundo Bernardes et al. (1998), a programação da obra pode ter uma vertente mais gerencial, onde são definidas ações estratégicas, em geral de médio e longo prazo, e outra operacional, com prazos mensais, semanais ou até diários para cumprimento de tarefas, repassados para o campo e discutidos entre as suas várias esferas (engenheiro de produção, mestre da obra, operários etc.).

As decisões estratégicas são aquelas analisadas com base na disponibilidade de tecnologia e equipamentos, previsão das condições ambientais e, essencialmente, avaliação de caminhos críticos das atividades. A elaboração de gráficos de Gant, redes tipo Pert-CPM, normalmente amparados em modelos computacionais auxiliares, é um instrumento interessante para o desenvolvimento dessa ação.

Nesse caso, a amplitude do tempo de análise de programação extrapola o prazo de execução da obra, a fim de facultar ao condomínio a possibilidade de análise das diversas alternativas de ação, auxiliando, com isso, a sua tomada de decisões.

A programação em nível operacional atinge um período mais curto de análise, partindo do prazo geral para a execução total da obra até a definição das tarefas semanais, ou até diárias.

A produtividade dos serviços tem uma parcela de extrema importância para uma correta programação operacional, pois a partir dela podem ser previstas e definidas questões básicas como número de funcionários e equipamentos necessários, prazos para liberação da aquisição de materiais e interdição de áreas comuns, entre outros.

Para esse caso é muito comum a elaboração de cronogramas físicos, gráficos de barras ou quaisquer outras técnicas que possibilitem a expressão clara das metas a serem atendidas durante o desenvolvimento das atividades, conforme exemplo apresentado na Figura 7. 


\section{CRONOGRAMAFÍSICO EXECUTADO X PREVISTO - MED. №009: MARÇO 2007}

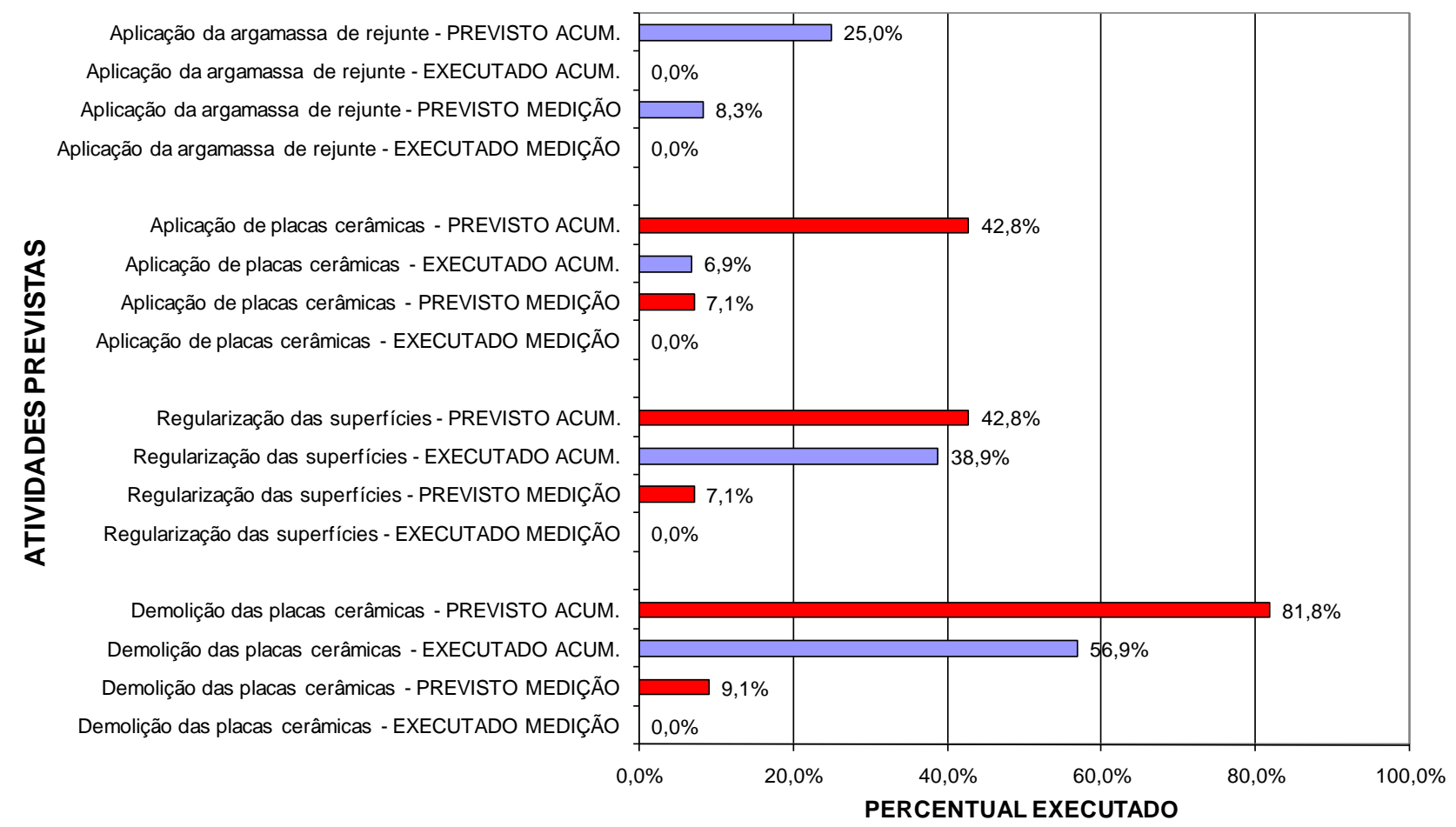

Figura 7 - Exemplo de gráfico de barra para acompanhamento do cronograma físico da obra.

É intuitivo imaginar que esse trabalho de programação operacional com apresentação de metas e resultados facilita as atividades posteriores de controle. Um meio eficaz é o acompanhamento dos serviços por meio de fichas de produção, nas quais são descritas informações básicas do serviço realizado, tais como datas, horário de início e final da jornada, nome do operário, e também a quantidade executada, permitindo, assim, a determinação da produtividade no período de tempo desejado (dia, semana, mês).

A partir dessas informações percebe-se que a programação operacional, via de regra, é mais flexível e sujeita a ajustes durante o decorrer dos serviços do que a estratégica. É dependente, porém, da velocidade de coleta, processamento e retroalimentação dos dados obtidos, que é função básica das atividades de controle, melhor detalhadas em itens posteriores do texto.

Apesar da distinção apresentada na presente abordagem, deve-se entender que as programações (estratégica ou operacional) são bastante correlatas e dependentes, de modo que é importante a sua compatibilização para o sucesso da atividade. 
Assim, a programação dos serviços deve contemplar discussão da melhor maneira de se desenvolver as atividades utilizando-se gráficos de redes, conceitos de caminhos críticos, entre outros, além da análise da disponibilidade de recursos tecnológicos e financeiros em conformidade com as necessidades da obra.

\subsubsection{Orçamento e levantamento de custos}

A etapa seguinte de realização do planejamento é o orçamento, em que são definidas quantidades e custos para a realização da atividade prevista. É precisa a definição de Parker (1994) para o orçamento de um projeto como a previsão dos custos dos serviços a serem realizados numa obra após a sua conclusão, dentro de um nível aceitável de variação.

Como aborda Ruano (1997), uma das mais importantes respostas a serem dadas num trabalho de investigação é a proposição de alternativas de intervenção com os seus respectivos custos e prazos estimados, que servirão de referência para a tomada de decisão.

No trabalho desenvolvido por Zelouf (1992) sobre obras de manutenção em edifícios públicos nos Estados Unidos, é enfatizada a necessidade imperativa da definição dos custos envolvidos para uma adequada tomada de decisão a partir das alternativas possíveis de intervenção (restauração de fachada, alterações no lay out).

Já durante o diagnóstico das causas é apresentada ao condomínio uma estimativa dos custos da obra, que servirá apenas como referência do total a ser gasto na obra. Apenas após a conclusão do projeto, no caso o diagnóstico das causas, a definição da alternativa escolhida para a intervenção, e os seus respectivos procedimentos executivos, é finalmente possível a elaboração do orçamento.

É opinião recorrente entre pesquisadores nacionais e internacionais (AL-HAJJ, 1999; ROSSO, 1990; SEELEY, 1987; STONE, 1980, todos citados por MEIRA e HEINECK, 2004) que os custos totais da obra devem ser compostos pela junção dos custos iniciais de construção com aqueles correspondentes às atividades de uso, como operação e manutenção. Al-Hajj (1999) apud Meira e Heineck (2004) comenta, por outro lado, que a disponibilidade de informações referentes à etapa de construção é, em geral, bem mais detalhada e precisa do que aquelas referentes à etapa de manutenção, o que pode desestimular as empresas a efetuarem esse tipo de previsão de custos desde o projeto. 
Em artigo publicado por Parker (1994) são apresentadas as principais fontes de erros em orçamentos ocorridos antes e após a sua elaboração, conforme descrito na Tabela 10.

Tabela 10 - Fontes de erros em orçamentos de obras (adaptado de Parker, 1994).

\begin{tabular}{l|l}
\hline $\begin{array}{c}\text { Fontes de erros decorrentes de ações tomadas ANTES } \\
\text { da elaboração do orçamento }\end{array}$ & $\begin{array}{l}\text { Fontes de erros decorrentes de ações tomadas APÓs } \\
\text { a elaboração do orçamento }\end{array}$ \\
\hline $\begin{array}{l}\text { As necessidades dos proprietários são pouco } \\
\text { discutidas e mal definidas. }\end{array}$ & $\begin{array}{l}\text { Falta de entendimento entre os envolvidos a respeito } \\
\text { do escopo do projeto. }\end{array}$ \\
\hline Projeto e planejamento inadequados. & Pouca clareza de informações para o projetista. \\
\hline Inexistência de programação para projeto e execução. & $\begin{array}{l}\text { Deficiência de controle e inabilidade em conduzir } \\
\text { alterações eventuais de rumo. }\end{array}$ \\
\hline No caso de obras públicas os orçamentos são forçados & $\begin{array}{l}\text { Dificuldade em avaliar os novos custos decorrentes de } \\
\text { eventuais alterações. }\end{array}$ \\
\cline { 2 - 2 } a chegar em determinados patamares de custos, em \\
detrimento da discussão das reais necessidades.
\end{tabular}

Existem algumas maneiras diferentes de se elaborar um orçamento, por exemplo, a partir da adequação das operações a serem realizadas na obra com a sua programação, chamado operacional, por meio de determinação de constantes de consumo de materiais e mão-de-obra por unidade de serviço, conhecido como paramétrico, e o convencional, no qual são definidos insumos e composições analíticas que têm o preço total estabelecido por meio da multiplicação das quantidades executadas pelos respectivos custos unitários (LIBRELOTTO et al., 1998).

Nesse caso, para a definição do preço final dos serviços é necessário ainda levar em conta os custos indiretos incidentes, tais como despesas administrativas, comerciais etc., e o benefício ou lucro da empresa, o conhecido $\mathrm{BDI}^{23}$.

O impacto das despesas indiretas, conceitualmente entendidas como valores gastos para pagamento de atividades de apoio, mas não diretamente relacionadas com a obra, depende de cada empresa e da sua estrutura de suporte (administração, número de funcionários administrativos, quantidade de obras etc.).

Por isso, a proposição, pela gerência da obra, de um BDI de referência pode dificultar a análise financeira dos serviços pelas empresas concorrentes, sendo mais indicado deixar

${ }^{23} \mathrm{BDI}$ - do inglês "Budget Difference Income", traduzido livremente para a língua portuguesa como "Bônus e Despesas Indiretas" 
esse parâmetro em aberto para definição de cada uma. Também há situações em que algumas das despesas indiretas são explicitadas na própria planilha orçamentária (controle tecnológico, por exemplo), o que deve reduzir o valor do BDI apresentado pelas empresas concorrentes.

O ponto de partida para a elaboração do orçamento é a definição das atividades a serem desenvolvidas, com base nos serviços necessários para a execução da obra e nos seus respectivos procedimentos executivos.

Importante destacar nesse ponto que durante a discussão das alternativas disponíveis para a intervenção se devem prever, com a maior precisão possível, todas as atividades necessárias para a obra, sob pena de haver necessidade posterior de aditivos sempre indesejados pelo investidor ou proprietário. Mas, por outro lado, uma previsão inicial acima do real executado também poderá causar um desconforto junto aos envolvidos.

Esses aspectos são especialmente importantes porque são atividades que, apesar de estarem sendo coordenadas por um gerente, na realidade são custeadas por todos os condôminos, cujos conflitos de interesses, já anteriormente comentado, são de difícil administração.

As atividades a serem executadas, depois de definidas, servem como base para a elaboração das composições analíticas de serviços, compostas pelos insumos diversos e pelas respectivas quantidades unitárias. As composições podem ser obtidas em tabelas disponíveis em literaturas, como a Tabela de Composições e Preços para Orçamentos (TCPO - Editora Pini), ou mesmo em tabelas próprias desenvolvidas por cada empresa, que representam a sua realidade específica.

Cabe ressaltar que, além das composições relativas às atividades de execução propriamente ditas, alguns orçamentos apresentam, em separado, itens referentes a serviços preliminares, como aluguel, mobilização e montagem de equipamentos, instalação de infra-estrutura no canteiro (aluguel de contêiner, montagem de barracão etc.), e serviços finais como limpeza geral das áreas comuns. Trata-se de uma prática interessante, pois favorece a interpretação do investidor ou proprietário por item, em separado, e facilita também as atividades de medição e pagamento. 
Principalmente no que tange aos serviços preliminares é necessária a avaliação conjunta com a programação da obra para determinação do prazo de aluguel e tipos de equipamentos utilizados (balancins do tipo elétrico ou de catraca, por exemplo), extensão das telas de proteção em função do número de frentes simultâneas de serviço, entre outros.

A etapa seguinte do trabalho é o levantamento dos quantitativos dos serviços, conforme as composições estabelecidas. Para obras em fachadas, esse serviço deve ser efetuado por meio de medições efetuadas "in loco", que podem ser também confrontadas com dados eventualmente disponíveis em projetos de arquitetura do prédio. Vale destacar que o estudo exclusivo desses projetos pode conduzir a erros consideráveis de levantamento, de modo que é imprescindível a conferência das cotas no local.

Em decorrência das várias circunstâncias que cercam esse tipo de serviço, é interessante o levantamento e apresentação para o condomínio das áreas de fachada separadas por trechos, que pode ser enviado por meio de uma documentação independente do orçamento. Esse procedimento permite o estudo de alternativas de implantação de frentes de serviço em conformidade com a programação estabelecida, e favorece ainda a mensuração de eventuais alterações propostas ao longo do desenvolvimento de serviços.

A medição dos serviços efetivos de produção é normalmente efetuada a partir de grandezas dimensionais (metro quadrado, metro linear), levando-se em conta as condições específicas de cada serviço. Já as composições referentes a equipamentos podem ser feitos por unidade de tempo (meses, semanas), e os itens diversos, como instalação de canteiro de obras e serviços de terceiros, por meio de estimativa de verba.

Considerando os impactos negativos oriundos de erros decorrentes do levantamento das quantidades de serviços é interessante a comparação dos valores encontrados com listas de verificação obtidas em outras edificações, em que estejam definidos parâmetros de referência, como perímetro $\mathrm{x}$ número de pavimentos $\mathrm{x}$ área média de fachada, ou área média x índice de esbeltez (relação altura : largura).

Outra atividade necessária para a elaboração do orçamento é a cotação para obtenção dos preços praticados no mercado referentes aos insumos presentes na planilha. Existem diferentes maneiras de se fazer essa pesquisa, como a consulta a empresas especializadas e revistas técnicas periódicas (Revista Construção, por exemplo), e 
verificações em lojas e armazéns. Interessante nessa etapa do trabalho que, novamente, sejam realizadas comparações para validação e comprovação dos dados obtidos.

No estudo dos custos referentes à mão-de-obra direta devem ser avaliados também os encargos sociais incidentes, variáveis de região para região, assim como os reajustes decorrentes do dissídio anual da categoria.

Com isso, a apresentação do orçamento é realizada por meio de uma planilha que contempla as composições analíticas e suas respectivas unidades de referência, preços unitários e preços totais, separadas por categorias macro de atividade (serviços preliminares, demolição, assentamento, serviços finais etc.). À soma dos valores obtidos em cada composição se incide o percentual correspondente ao BDI para obtenção do preço total da obra.

Por fim, é interessante destacar que um bom orçamento não é sinônimo de redução nos custos da obra, mas pode servir com excelente instrumento de apoio às atividades de tomada de decisões e controle tecnológico e operacional. Como destaca Parker (1994) o adequado controle dos custos não garante redução dos valores, mas permite reconhecer os eventuais desvios de rumo, possibilitando a realização de intervenção a tempo.

A atividade de planejamento deve ainda, necessariamente, contemplar a escolha das empresas e discussão de aspectos contratuais diversos que estão envolvidos. Serviços de engenharia desta natureza, em geral, envolvem aporte de recursos suficiente para a ocorrência de disputas licitatórias onde devem estar claramente definidas as regras e restrições às empresas, obrigações diversas (fiscais e trabalhistas) e critérios de julgamento.

\subsubsection{Seleção das empresas concorrentes - procedimento e critérios de escolha}

Antes da definição da empresa executante e das diretrizes presentes no contrato é necessária uma convocação das empresas potencialmente concorrentes para a realização da obra. Nessa etapa são definidas as restrições impostas para a habilitação e os critérios adotados para o julgamento.

Existem várias restrições a serem impostas às empresas concorrentes, a depender de cada situação. As obras públicas, por exemplo, possuem regras específicas para restrição, 
mas algumas questões básicas estabelecidas para a maioria dos casos estão apresentadas a seguir:

- Comprovação da realização de serviços similares, com apresentação da $\mathrm{ART}^{24}$. Nesse caso pode ser estipulada, por exemplo, uma quantidade mínima de metros quadrados executados em obras afins pela empresa ou pelo seu responsável técnico legal. Caso seja julgado pertinente, a fim de evitar que esse responsável técnico seja contratado para a realização da obra, de modo que não reflita a experiência dos demais componentes da empresa em serviços similares, pode-se solicitar que o mesmo comprove vínculo funcional mínimo de 12 meses, por exemplo.

- Porte da empresa compatível com o nível da obra, que pode ser avaliado a partir do seu capital social, no mínimo correspondente a $25 \%$ do valor total dos serviços.

- Apresentação de documentação mínima como certidão negativa de débitos junto à Receita Federal, comprovação de existência na junta comercial da região, contrato social, quitação de débitos junto ao INSS, FGTS, CONFINS, tudo em conformidade com a legislação pertinente.

Trabalho apresentado por Attalla e Hegazy (2003) discute a necessidade da elaboração, pelos agentes gestores (proprietário, construtor e consultor) de um documento de intenções ("tender document"), do tipo cartas consulta ${ }^{25}$, a ser encaminhado às empresas concorrentes, procedimento recomendado pela presente pesquisa.

É proposta da presente pesquisa a apresentação desse documento de intenções, elemento chave para a orientação de todos os agentes envolvidos na definição das ações condutoras da manutenção, que deve contemplar:

- Estudo exploratório das causas ou razões para a intervenção.

- Critério para habilitação e seleção das empresas concorrentes.

- Descrição detalhada do procedimento executivo a ser adotado nas várias fases da obra.

\footnotetext{
${ }^{24}$ ART - Anotação de Responsabilidade Técnica.

${ }^{25}$ No Anexo C é apresentado exemplo modelo de carta consulta (documento de intenções).
} 
- Especificações de materiais, inclusive critérios de escolha e controle de aceitação.

- Detalhamentos diversos de projeto, de preferência utilizando interface gráfica, figuras, desenhos.

- Programação e orçamento dos serviços (ver itens 4.2.1.1 e 4.2.1.2, respectivamente), com ou sem os preços, a depender do caso.

- Questões contratuais diversas (item 4.2.3).

- Previsão das atividades de controle tecnológico e operacional (Item 4.3).

Para evitar qualquer tipo de contestação das empresas ao final da escolha, é imprescindível a citação na documentação enviada às empresas concorrentes, além da minuta básica de contrato, ainda a ser negociada, também dos critérios de julgamento que serão adotados. Essa definição não apenas facilita o entendimento das empresas, como também torna transparente a tomada de decisão do representante do condomínio junto aos seus próprios afiliados.

Como ocorre na maioria das licitações para execução de obras, somente as empresas concorrentes aprovadas quanto às restrições anteriormente citadas estão habilitadas, devendo ser então avaliadas conforme a proposta financeira apresentada. Assim, é prática comum as empresas entregarem em envelopes separados a documentação requerida e a proposta comercial, que só é analisada caso a primeira atenda às exigências estabelecidas. Observa-se a recomendação pela adoção desse procedimento na maior parte dos trabalhos estudados na presente pesquisa (KARAM, 2005; TENAH, 2000).

Um mecanismo muito eficiente para a tomada das propostas junto às empresas concorrentes para execução dos serviços é o fornecimento de uma planilha básica de referência, a qual, apenas para o condomínio, é fornecida com os preços praticados no mercado ${ }^{26}$.

Evidente que na documentação enviada às empresas concorrentes, na planilha básica, não são contemplados os preços pesquisados de mercado, de modo que as mesmas devem preencher apenas esses campos para composição do valor final. As planilhas

\footnotetext{
${ }^{26}$ Discussão detalhada é apresentada no item 6.3 - Método final validado.
} 
orçamentárias entregues então podem ser compiladas lado a lado, permitindo a comparação de cada item para a escolha final.

Não são raros os casos de discrepâncias acentuadas entre valores de propostas de empresas concorrentes para serviços, em tese, idênticos, motivadas pela indefinição quanto aos procedimentos executivos, quantitativos e exigências diversas, e também pelo desconhecimento técnico especializado do investidor ou proprietário, solicitante do serviço.

Yiu et al. (2002) apresentam estudo de casos em que as diferenças de preços entre as propostas apresentadas pelas empresas chegavam até a $300 \%$, o que foi creditado, dentre outros fatores, às deficiências nas informações disponíveis para os concorrentes e mesmo no contato com o contratante, o que pode ser atenuado a partir da elaboração desse documento de intenções.

Uma vez definida a planilha básica orçamentária para a realização dos serviços, é possível que o condomínio possua uma idéia bastante aproximada do valor total da obra, conforme já anteriormente mencionado. Com isso, pode-se estabelecer um intervalo de valores propostos (por exemplo, distantes $30 \%$ do valor obtido) aceitos para análise. Dessa forma, evita-se a perda de tempo na avaliação de propostas de preços acima dos praticados no mercado, e também daqueles que possam estar, num primeiro momento, dispostos a arcar com custos mais baixos que o mercado, e cujos riscos de não conclusão dos serviços são evidentes.

No trabalho elaborado por Yiu et al. (2002) é apresentado estudo de caso em que houve o encaminhamento de propostas para execução de um serviço de manutenção de fachada no qual as diferenças de preços variam de $-61 \%$ a $+56 \%$, em relação ao valor de referência previsto. Em outro caso descrito também nesse artigo, que trata da atualização do sistema de segurança de prédios de alto padrão, as diferenças entre os preços apresentados e a referência foram de $-25 \%$ até $+206 \%$.

Evidente que fica facultado às empresas acrescentar sugestões ou outras recomendações, as quais, porém, são apresentadas em separado para análise da sua adequação às necessidades da obra. Outro aspecto importante é que as empresas concorrentes devem conferir o levantamento dos quantitativos previstos na planilha, podendo inclusive contestá-lo, se for o caso, pois após a entrega das propostas as mesmas 
assumem esses valores como verdadeiros, não cabendo mais nenhum tipo de alteração ou contestação.

A definição da escolha comercial a partir do valor mais baixo apresentado pelas empresas habilitadas é tentador e muito empregada pelos condomínios. Entretanto, a realização de um planejamento adequado permite a avaliação das propostas por meio de critérios técnicos que tornam a escolha mais confiável e segura.

Documento útil e complementar à planilha orçamentária é o cronograma financeiro da obra, que explicita os gastos realizados ao longo da obra por períodos de tempo determinados (meses, semanas). O cronograma ajuda o investidor ou proprietário a definir um plano de liberação de verbas para o suprimento, a depender do tipo de contrato firmado, e pode servir também para que sejam avaliadas possibilidades de aplicações e rentabilidade das verbas eventualmente disponíveis para a obra, antes da sua utilização.

Nas situações especiais em que sinta necessidade, o condomínio (contratante) pode determinar o estabelecimento de notas dadas aos critérios exigidos e atendidos com mais relevância pelas empresas para a composição da escolha final.

Existem diversas maneiras de se julgar empresas concorrentes para a execução de uma obra, porém quase sempre são levados em conta os aspectos legais e comerciais anteriormente citados. Em todos os casos, entretanto, é importante que fique claro no documento de intenções que o condomínio tem autonomia total para vetar a participação de qualquer empresa, mesmo que aprovada no item de habilitação, em função de uma informação ou repercussão negativa colhida em uma fonte julgadora confiável.

Como já salientado, um instrumento eficiente para reduzir a ocorrência de equívocos durante a escolha da empresa executante da obra é a definição de um critério de seleção devidamente definido e explicitado no documento de intenções enviado às concorrentes. Segundo Attalla e Hegazy (2003), algumas das recomendações devem ser: cumprimento às exigências diversas técnicas e operacionais previstas no documento; experiência comprovada em serviços similares; referência de profissionais especialistas; habilidade em gestão de projetos; registro das ações de segurança.

Christodoulou et al. (2004), em trabalho a respeito dos critérios de qualificação indicados para a escolha de profissionais de engenharia e arquitetura, contrapõem as 
decisões pelo menor preço com as decisões definidas pela qualificação dos concorrentes. Trata-se de uma discussão polêmica, a partir da qual vários pontos de vista são abordados, conforme descrito na Tabela 11.

Tabela 11 - Características inerentes à atividade de seleção dos profissionais de engenharia e arquitetura (Christodoulou et al., 2004).

\begin{tabular}{|c|c|}
\hline SELEÇÃO PELO MENOR PREÇO & SELEÇÃO PELA QUALIFICAÇÃO \\
\hline $\begin{array}{l}\text { - Possibilita a execução do serviço com o menor } \\
\text { custo possível para o contratante. } \\
\text { - Independente do que foi contratado o serviço é o } \\
\text { mesmo, não importa o responsável pela sua } \\
\text { execução. } \\
\text { - Trata-se do método mais utilizado em obras } \\
\text { públicas nos EUA. } \\
\text { - As dúvidas devido a eventuais fraudes ou } \\
\text { favorecimentos são reduzidas. } \\
\text { - Não há escolha apenas pela "experiência" ou } \\
\text { tempo de serviço dos concorrentes, mas sim por } \\
\text { preço. }\end{array}$ & $\begin{array}{l}\text { - Permite maior liberdade de escolha, com menor } \\
\text { risco de falhas oriundas de descuidos. } \\
\text { - A análise por preços induz aos participantes a } \\
\text { trabalhar de forma mais "enxuta" possível, uma } \\
\text { vez que as empresas concorrentes são admitidas } \\
\text { como "iguais". } \\
\text { O barato pode sair caro caso os objetivos não } \\
\text { sejam alcançados. } \\
\text { Análise por preço favorece o surgimento de } \\
\text { aditivos e a necessidade de maiores atividades } \\
\text { de manutenção. } \\
\text { A avaliação contempla demonstração de } \\
\text { qualificação técnica (vários aspectos são } \\
\text { somados conforme o peso e a relevância), junto } \\
\text { com aspectos de preço. }\end{array}$ \\
\hline
\end{tabular}

Yiu et al. (2002), citando ainda outros pesquisadores, salientam que a escolha da empresa concorrente a partir do preço mais baixo não garante a melhor qualidade do serviço. Esses autores apresentam trabalho realizado em obras de pequeno porte na cidade de Hong Kong no qual se discute a importância de se definir de forma eficiente os critérios de seleção das empresas, destacando ainda que a realização de entrevistas junto aos concorrentes pode ajudar a eliminar eventuais futuros problemas.

A escolha pelo menor preço, como enfatiza Karam (2005), acarreta num maior risco para o contratante, na medida em que são pouco considerados aspectos técnicos. Segundo esse autor, a seleção pela qualificação é indicada quando se tem pequeno número de empresas envolvidas, e deve contemplar aspectos integrados de custo, prazo e qualidade. 
Hatush e Skitmore (1997) também destacam que o critério de seleção das empresas concorrentes para execução dos serviços de engenharia deve privilegiar questões de qualidade dos serviços, prazo de execução e, naturalmente, custos.

Sönmez et al. (2002) enfatizam que a seleção dos profissionais é importante tanto para os contratantes (condomínio), uma vez que elimina concorrentes incompetentes e sem suporte financeiro, como também para os contratados (construtores), pois funciona como uma garantia de transparência das ações tomadas, como numa auditoria. Esses autores apresentam nesse trabalho estratégias para a seleção, que contemplam a avaliação da satisfação a critérios previamente determinados, com eliminação gradativa na medida em que a empresa não os atendam, e decisões baseadas na experiência e conhecimento dos concorrentes.

No artigo publicado por Tenah (2000) é apresentada discussão comparativa a respeito de duas técnicas utilizadas para escolha de empresas dos EUA para a execução de obras, a saber:

- Design - Bid - Build: para cada uma das fases do empreendimento (projeto, análise das propostas, execução) é contratada uma empresa independente, responsável pelas suas ações no âmbito do serviço efetuado, ocorrendo assim uma divisão de responsabilidades e distanciamento entre os envolvidos.

- Design - Build: as ações são todas centralizadas em uma empresa gerenciadora, responsável pela contratação dos diversos serviços e parceiros para a obra, o que obriga uma maior integração entre os envolvidos.

$\mathrm{Na}$ opinião do referido autor, com a qual concorda Karam (2005), é preferível o método de contratação por meio de empresa gerenciadora, cujas principais vantagens apontadas são: maior compatibilidade de interesses, redução de trabalho por parte do contratante, menores prazos e custos para execução dos serviços, diminuição do número de alterações no projeto e de reclamações por parte dos usuários, redução do contato entre contratante e contratado (de relação naturalmente conflituosa), e seleção dos parceiros baseada na qualificação. Além desses, um aspecto julgado muito importante é a redução de "responsáveis", isto é, na ocorrência de eventuais problemas o contratante deve-se reportar a apenas uma entidade, e não a várias empresas atuantes no projeto. 
Em contrapartida, ainda segundo Tenah (2000), essa técnica de contratação obriga o contratante a adotar uma postura atenta para evitar a tendência de haver algum tipo de favorecimento e "cobertura", entre as empresas participantes da obra, de problemas diversos ocorridos, tais como falhas de projeto, retrabalho, reclamações etc. Com isso, é preciso um acompanhamento mais direto na obra por parte do contratante.

O conceito de centralização reforça a idéia defendida no presente trabalho de gestão das atividades de recuperação de fachadas coordenada por equipe especializada de consultoria para dar suporte técnico às decisões tomadas pelo condomínio, com a diferença de que, nos casos apresentados, a gerenciadora deve cuidar também da execução dos serviços, o que não é proposto nessa tese.

\subsubsection{Aspectos contratuais}

Etapa complementar e fundamental no gerenciamento para execução de uma obra é a gestão contratual, sob cuja responsabilidade recai a definição de assuntos que vão desde preços até as obrigações das partes envolvidas.

Entende-se como contrato a formalização dos direitos e responsabilidades entre sujeitos dispostos a realizar transações comerciais entre si, que deve assumir legitimidade e valor jurídico para tal.

Como bem afirmam Hatush e Skitmore (1997), uma contratação não plajenada leva ao cliente o risco de selecionar empresas com inadequada habilidade e capacidade para o serviço.

Em se tratando da prestação de um serviço em que de um lado se encontra um condomínio, composto por várias unidades (e vontades) e representado pelo administrador (síndico), e por outro uma empresa executante de atividades diversas de manutenção, várias são as dificuldades encontradas, como se segue:

- Trata-se de uma relação que exige o máximo de transparência, pois há interesses de vários elementos atuando conjuntamente.

- É uma relação, em geral, de médio a longo prazo, que, por isso, requer um regime de convivência o mais harmonioso possível entre todos os envolvidos. 
- Envolve uma gama de recursos substanciais, repartidos entre os vários clientes, cujos níveis de exigência podem ser diferentes, acarretando em interpretações distorcidas acerca dos acontecimentos ocorridos na obra.

Com base em questões como as apresentadas, é fácil concluir que o contrato é o instrumento mais eficiente para dirimir previamente as questões que venham a surgir na obra, protegendo, portanto, as partes interessadas de eventuais futuros transtornos ou desacordos. É natural imaginar que nem sempre é possível prever todos os empecilhos que possam ocorrer na obra, o que valoriza a necessidade de profissionais especializados técnica e operacionalmente para o seu gerenciamento.

Existem diferentes formas jurídicas de se preparar um contrato de serviço para execução de obras de manutenção de fachada. Em todos os casos, porém, trata-se da prestação de serviço entre uma parte, o construtor (contratado), que fornece mão-de-obra, equipamentos diversos e materiais, e outra parte, o condomínio (contratante), cuja principal responsabilidade é a provisão de recursos e, em alguns casos, também a aquisição de materiais. Em muitas situações existe ainda a figura do agente gestor, que coordena as atividades a serviço do condomínio, servindo como elo entre as partes citadas.

Segundo a NBR 5674 (ABNT, 1999), a contratação de serviços de terceiros pode ser efetuada da seguinte forma:

- Preço fixo com base em serviço claramente definido - a empresa executante apresenta um valor total (empreitada global) para realização dos serviços prédeterminados, sujeito ou não a reajustes ao longo da obra, contemplando o fornecimento de materiais, equipamentos diversos e mão-de-obra. Nesse caso, ao contratante cabe a responsabilidade exclusiva do pagamento dos serviços e eventuais obrigações contratuais de caráter operacional (energia, acesso aos locais de trabalho, espaço no canteiro de obras etc.).

- Preço unitário - a empresa recebe por serviço medido e efetivamente realizado.

- Contrato global por período determinado - a empresa responde pela manutenção da edificação em funcionamento, a partir de um preço previamente acertado.

- Por administração - com essa modalidade a empresa executante apresenta ao condomínio os custos correspondentes aos gastos ocorridos na obra durante 
determinado período, sobre os quais incide uma taxa percentual pré estabelecida como forma de pagamento. Com isso, as despesas são todas registradas em favor do condomínio, que necessita forte controle para acompanhamento dos itens apresentados.

Existe ainda uma modalidade não claramente expressa na referida norma:

- Contrato por empreitada parcial - difere da empreitada global, pois o condomínio assume algumas das responsabilidades da empresa executante, em geral, referente a equipamentos, materiais ou ambos. Quando o condomínio dispõe de infra-estrutura para a gestão dos suprimentos, essa modalidade contratual é bastante utilizada, uma vez que evita a incidência de tributação duplicada sobre esses artigos, especialmente os materiais. Nesse caso observa-se uma maior divisão de responsabilidades entre as partes, possibilitando, entretanto, redução nos custos finais da obra.

A despeito da modalidade de contratação adotada na obra, são vários os elementos que devem estar com critérios e parâmetros definidos e claramente identificados por meio de cláusulas ou parágrafos. Alguns dos aspectos mais importantes estão a seguir discutidos, os quais podem ser apresentados nas cartas-convite encaminhadas às empresas concorrentes à obra.

\subsubsection{Prazos}

É o estabelecimento da quantidade de dias previstos para a execução dos serviços. Cabe destacar que não é no contrato que são definidos os prazos. Nessa etapa ocorre apenas a explicitação dos prazos previamente definidos e discutidos. É importante que sejam considerados e explicitados os dias úteis, descontados finais de semana, feriados e dias parados em decorrência das condições ambientais, variáveis conforme a região e a época do ano.

Infelizmente, como salienta Kumar (2005), na indústria da construção são comuns a dilatação dos prazos estimados para conclusão dos serviços, o aumento nos custos previstos para a obra, além de problemas de qualidade.

Podem ser previstas sanções, do tipo multas, ou advertências gradativas na eventualidade da ocorrência de atrasos para a conclusão da obra. A experiência mostra que 
a falta de planejamento de muitas das empresas executantes, associada à indefinição clara de punições aos infratores, concorrem para um grande número de casos registrados com problemas decorrentes do não cumprimento de prazos.

Hatush e Skitmore (1997), por exemplo, recomendam a definição de bônus no contrato para incentivar a empresa executante a reduzir os tempos e prazos de execução das obras.

Importante frisar que, por mais atuantes que sejam, as atividades de controle (fiscalização) não são suficientes para garantir a execução das obras dentro do tempo inicialmente previsto, uma vez que cabe à fiscalização apenas o acompanhamento, com base na produtividade, do prazo para a conclusão das atividades ao longo da obra, e o repasse dessa informação ao condomínio e à empresa executante.

\subsubsection{Preços e reajustes}

Os valores correspondentes aos serviços a serem executados na obra são explicitados em contrato por meio da planilha básica orçamentária, definida após negociação com a empresa executante.

Parker (1994) destaca que os preços utilizados na elaboração de um orçamento devem ser estimados levando-se em conta o tipo e as características do empreendimento, de modo que se obtenha um custo global o mais próximo possível da realidade.

Importante comentar que os preços previstos no contrato devem atender aos valores praticados no mercado, uma vez que distorções acentuadas podem ser indicativas de inadequação da proposta às condições da obra. Hatush e Skitmore (1997) destacam que contratos com valores muito baixos, na maioria dos casos, terminam com custos adicionais maiores do que os originais.

A depender do prazo de execução das atividades é necessária a previsão de reajustes dos valores em virtude de correções monetárias e aumento de preços da mão-de-obra. No primeiro caso existem índices paramétricos da construção (INCC ${ }^{27}$, por exemplo) que podem

${ }^{27}$ O INCC (Índice Nacional de Custo da Construção) é um índice de periodicidade mensal, elaborado pela Fundação Getúlio Vargas, que afere a evolução dos custos de construções habitacionais. 
balizar a previsão dos reajustes, sendo interessante ainda a inclusão de cláusula que preveja revisão dos preços em virtude movimentos econômicos globais expressivos, de difícil previsão.

Os custos com mão-de-obra, conforme já anteriormente citado, sofrem correções anuais coincidentes com o dissídio da categoria, podendo-se fazer um prognóstico desse aumento com base na evolução histórica da região, ou adotar (repassar) diretamente tais valores.

Por fim, importante constar nesse item do contrato os procedimentos a serem adotados na eventualidade da ocorrência de imprevistos ao longo da execução dos serviços, tais como aumento abusivo nos preços dos materiais (importados, por exemplo) ou anormalidades diversas.

\subsubsection{Obrigações fiscais e trabalhistas}

As contribuições diversas a serem recolhidas pelas empresas executantes, apesar de determinadas pela legislação brasileira, devem ser ratificadas em contrato para evitar qualquer tipo de dúvida. As principais obrigações estão a seguir descritas de forma sucinta, uma vez que não é do escopo do presente trabalho discuti-las detidamente:

- Encargos sociais (trabalhistas):

○ INSS (Instituto Nacional de Seguridade Social) ${ }^{28}:$ Trata-se da contribuição devida à seguridade social, inclusive para financiamento de aposentadoria especial e benefícios concedidos em razão do grau de incapacidade laborativa decorrente dos riscos ambientais do trabalho. Interessante destacar que é facultado ao contratante recolher $11 \%$ sobre a nota fiscal, a quem caberá o recolhimento do tributo com identificação do $\mathrm{CEI}^{29}$ (Cadastro Específico do INSS) da obra. Sua quitação pode ser efetuada por meio de uma Guia de Previdência Social (GPS).

\footnotetext{
${ }^{28}$ Informações colhidas em <http://www.inss.gov.br/pg_secundarias>. Acesso em 11 jul. 2006.

29 Toda obra de construção civil (construção, demolição, reforma, ampliação) deve ser matriculada no
} INSS, num prazo máximo de 30 dias após o início das atividades, ocasião em que receberá um número de cadastro (CEI). Importante destacar que são peças imprescindíveis na matrícula: projeto de intervenção 
- FGTS (Fundo de Garantia por Tempo de Serviço): Parcela recolhida pelo empregador junto ao Governo por meio do preenchimento da GFIP (Guia de Recolhimento do FGTS e Informações à Previdência Social), incidente sobre a mão-de-obra empregada na execução da obra.

- Contribuições diversas a entidades de apoio às atividades dos trabalhadores e outras, nem todas aplicáveis a empresas de construção civil - Senai, Sesc, Senae, Sebrae, $\operatorname{Incra}^{30}$.

○ Salário educação, seguro contra riscos e acidentes de trabalho.

- Direitos diversos dos trabalhadores, que recebem a incidência direta dos demais itens citados, como: descanso semanal remunerado, feriados, férias, 1/3 constitucional de férias, auxílio enfermidade, acidentes de trabalho, descanso paternidade, aviso prévio trabalhado, adicional noturno, 13ㅇs salário.

- Encargos fiscais (impostos):

- IRPJ (Imposto de Renda sobre Pessoa Jurídica) ${ }^{31}$ : Recolhimento devido por toda pessoa jurídica ou empresa individual, cuja tributação pode-se dar a partir do lucro presumido, real, arbitrado, ou pelo regime simples.

- PIS (Programa de Integração Social) ${ }^{32}$ : Corresponde a um recolhimento efetuado pelas pessoas jurídicas com o objetivo de financiar o pagamento do seguro desemprego e do abono para os trabalhadores que ganham até dois salários mínimos. Todo empregado deve ser cadastrado junto ao PIS a fim que lhe seja assegurado também direito ao FGTS.

aprovado no CREA; Anotação de Responsabilidade Técnica (ART); alvará de concessão de licença para construção.

\footnotetext{
${ }^{30}$ Senai - Serviço Nacional de Apredizagem industrial.

${ }^{31}$ Informações colhidas em <http://www.portaldotributario.com.br>. Acesso em 11 jul. 2006.

32 Informações colhidas em <http://www.guiadedireitos.org/portal/V.trabalhoerenda>. Acesso em 11
} jul. 2006. 
- COFINS (Contribuição para o Financiamento da Seguridade Social) ${ }^{33}$ : É um tributo federal cobrado das pessoas jurídicas (exceto as microempresas e empresas submetidas ao regime do SIMPLES - Lei no9.371/96) que se destina a financiar a seguridade social, com apuração mensal e incidência direta, não cumulativa.

- ISS (Imposto Sobre Serviços) ${ }^{34}$ : Trata-se de um recolhimento efetuado pelo prestador de serviço, com alíquota mínima de 2,0\% (Emenda Constitucional 37/2002) e máxima de 5\% (artigo 8, II, Lei Complementar 116/2003), variável conforme a região do país.

- CSLL (Contribuição Sobre Lucro Líquido) ${ }^{35}$ : Contribuição federal recolhida das pessoas jurídicas com taxas variando de $8 \%$ sobre o lucro líquido a $12 \%$ sobre a receita bruta, de acordo com a sua opção contábil.

Uma prática adotada pelos condôminos para garantir o pagamento das obrigações fiscais e trabalhistas pelas empresas construtoras é o desconto direto nas medições dos serviços. Essa prática pode ser empregada para quitação do INSS, FGTS, IRPJ, PIS, COFINS, ISS e CSLL, de modo que a liberação do pagamento da medição só é efetuada mediante a apresentação das respectivas guias (GFIP, DAM e DARF) pagas.

Uma vez que os pagamentos do INSS e do FGTS se referem aos funcionários empregados na obra, e nas respectivas guias de pagamento são apresentados os nomes dos beneficiários, é importante confirmar esses nomes com aqueles constantes do controle de acesso à obra.

Esse procedimento serve também como garantia com relação ao eventual surgimento de ações trabalhistas de funcionários da própria empresa que não trabalharam na obra contra o condomínio, de modo que é prudente a existência de relação semanal dos operários efetivamente atuantes na obra, assinada por representantes da empresa construtora, da fiscalização e do condomínio.

\footnotetext{
${ }^{33}$ Informações colhidas em <http://pt.wikipedia.org/w/index.php>. Acesso em 11 jul. 2006.

${ }^{34}$ Informações colhidas em <http://www.portaldotributario.com.br>. Acesso em 11 jul. 2006.

${ }^{35}$ Informações colhidas em <http://www.receita.fazenda.gov.br>. Acesso em 14 jul. 2006.
} 
Importante considerar que, no caso de ações trabalhistas contra a empresa, o condomínio participa como responsável solidário, de modo que, na impossibilidade de pagamento pela empresa, o condomínio recebe a intimação para pagamento, o qual poderá ser posteriormente executado contra a empresa.

Ainda no âmbito das garantias, é prática consagrada nas obras públicas se atrelar o pagamento das parcelas à apresentação da Certidão Negativa de Débitos (CND) da empresa executante, comprobatória da quitação de todos os débitos fiscais. Conforme salientam Bressiani e Heineck (2004), a partir desse documento a obra pode ser considerada regular, não havendo débitos ou recolhimentos em aberto a cargo do contribuinte responsável.

\subsubsection{Pagamentos e retenções}

Existem diferentes formas de se definir a maneira de pagamento dos serviços pelo condomínio às empresas executantes, o que é, normalmente, bastante utilizado como instrumento de negociação entre as partes envolvidas. A forma de pagamento também está atrelada à modalidade de contrato adotada na obra.

A alternativa mais simples para o controle é a divisão do valor total em parcelas préfixadas (reajustáveis ou não), pagas em datas anteriormente definidas. Nesses casos pode-se ainda propor a extensão do pagamento a prazos superiores ao da obra, de modo que as obrigações do condomínio permanecem mesmo após a conclusão dos serviços.

Outra prática empregada é a liberação dos pagamentos de acordo com a medição dos serviços realizados. Nessa situação, são importantes algumas ações preventivas para evitar a ocorrência de discussões futuras: as quantidades executadas devem ser medidas em conjunto pelos agentes envolvidos (fiscalização e construtor); definição da liberação ou não do pagamento de serviços parcialmente concluídos; realização da quantificação acumulada dos serviços em cada medição, para efeito de conferência.

Existe também a possibilidade de liberação dos pagamentos de acordo com os valores previstos no cronograma financeiro apresentado na proposta das empresas concorrentes. Aqui, tanto o condomínio quanto a empresa executante podem fazer uma previsão mais precisa de receitas e despesas realizadas ao longo da obra. 
É lógico que há ainda uma grande variedade de possibilidades para pagamentos, porém as mais usuais são essas apresentadas anteriormente. Dentre as modalidades discutidas, a menos no caso das parcelas pré-fixadas, um mecanismo empregado para garantir ao condomínio o cumprimento das obrigações contratuais do construtor é a adoção de retenções incidentes sobre o valor total das medições.

Correspondentes a índices que, em geral, variam de $5 \%$ a $10 \%$, esses valores ficam retidos em poder do condomínio e serão pagos na conclusão da obra, ou após algum tempo pré-estabelecido para prevenir quanto a eventuais ações de ordem trabalhista que podem ser impetradas posteriormente. Ao valor da retenção podem ser estabelecidos índices de correção monetária para pagamento.

Alternativa possível para assegurar ao condomínio a conclusão da obra é a aquisição de um seguro de construção pela empresa executante, a quem caberá o seu ônus.

\subsubsection{Escopo do serviço e equipamentos}

Evidente que parte integrante fundamental do contrato é a explicitação dos procedimentos executivos, inclusive descrição de materiais e equipamentos a serem utilizados, e apresentação de detalhes construtivos dos projetos, se for o caso. Os procedimentos produtivos em si podem ser previamente determinados pelo condomínio, via empresa gerenciadora ou consultora, ou ainda ser propostos pela empresa executante para discussão e acordo. A definição clara do processo executivo é de grande importância para a referência das atividades futuras de acompanhamento.

Attalla et al. (2004), em artigo publicado sobre as vantagens da utilização dos departamentos internos de corporações americanas para realização das atividades de manutenção das suas edificações, destacam que definições imprecisas do escopo dos serviços contribuem de forma decisiva para o aumento dos custos e o insucesso da intervenção.

Nesse tópico, é também explicitada a especificação dos materiais e dos equipamentos usados durante a obra. No primeiro caso, isso serve como uma segurança tanto para construtores quanto para o condomínio da adequação do material, independente do agente responsável pela sua compra. Nesse sentido, são também apresentadas as 
atividades de controle tecnológico a serem exercidas na obra. Importante destacar a necessidade de se explicitar a quem caberão os custos decorrentes dessa atividade, que poderão estar previstos, inclusive, na planilha básica.

Quanto aos equipamentos, essa especificação pode ser determinante para o correto cumprimento dos prazos e de eventuais obrigações operacionais (ocorrência de barulho, sujeira, trânsito de operários na obra etc.). Os detalhes construtivos que podem advir, por exemplo, do posicionamento de juntas de movimentação ou respingadores, encontro de materiais de natureza diferenciada, ou detalhes artísticos mais elaborados são nesse item estabelecidos para elucidação de qualquer problema de ordem técnica.

\subsubsection{Segurança e higiene}

A construção civil é um ramo de atividade tida, muitas vezes, como de risco para os agentes envolvidos. Por conta desse histórico, tem sido desenvolvido grande esforço no sentido de reduzir as possibilidades de acidentes, contemplando desde a correta especificação de equipamentos e ferramentas de uso individual e coletivo até trabalhos de conscientização das mais diversas naturezas.

Vários estudiosos vêm dedicando a esse tema pesquisas específicas, e há um consenso geral de que também os cuidados com a higiene dos operários podem contribuir para a redução de problemas na obra.

Em trabalhos de manutenção de fachada realizados em edificações em uso as dificuldades são ainda maiores, pois, além de envolverem os cuidados normais com os operários que atuam em alturas, sobre equipamentos específicos, é preciso que sejam previstas ações preventivas para os habitantes e usuários do prédio (inclusive os seus funcionários), e também para os transeuntes que passam pelas vias públicas próximas ao imóvel e para edificações vizinhas.

Vários são os relatos encontrados de problemas de equipamentos em fachadas, como ocorrido na cidade de Fortaleza, em 2007, quando quatro operários ficaram perdurados pelos cabos de segurança por conta da ruptura dos apoios dos balancins durante 
as obras de recuperação do prédio do DNOCS $^{36}$ (Departamento Nacional de Obras Contra as Secas). Apenas após 15 minutos dois dos operários conseguiram alcançar uma janela próxima, enquanto os outros dois foram salvos pelo Corpo de Bombeiros.

Essa preocupação é abordada no BRE (2001), que destaca a responsabilidade legal dos ocupantes e proprietários por danos provenientes da fachada causados a usuários, visitantes, vizinhos e empregados.

Com isso, é importante a previsão em contrato de ações de caráter operacional e de conscientização (treinamento). No primeiro caso, algumas providências básicas mínimas são essenciais, como:

- Uso completo em todo o tempo dos EPI’s (equipamentos de proteção individual).

- Apresentação, pela empresa executante, dos cálculos estruturais referentes aos elementos de sustentação dos balancins e seus apoios.

- Utilização de tela de proteção ao longo de toda a extensão da área em que estiver realizando a atividade, atentando-se para a necessidade de garantir a amarração das cordas laterais de sustentação, sob pena de haver trechos expostos em função da ação do vento.

- Instalação de aparato superior de proteção dos operários nos balancins, caso necessário.

- Descida ou amarração dos balancins nos intervalos de tempo em que não estejam sendo desenvolvidas as atividades. A depender das condições ambientais previstas (clima, vento) e da quantidade de tempo parado (fins de semana, feriados) pode ser necessária a descida para amarração desses equipamentos no piso.

- Previsão, por meio de desenhos esquemáticos, do estudo do "lay-out" do canteiro de obras (nesses casos, em geral, as áreas de uso comum do prédio), inclusive com as suas alterações, e respectivos prazos, a serem implantados ao longo do serviço.

\footnotetext{
${ }^{36}$ Informação disponível em: <http:// www.oglobo.globo.com/pais/mat/2007/03/02/294782956.asp>.
} Quatro operários se salvam de acidente com andaime. Acesso em: 02 abr. 2007. 
- Sinalização em linguagem clara e de fácil visualização nas diversas áreas de uso do prédio.

As ações de caráter não operacional envolvem exigências a serem impostas às empresas quanto à comprovação de capacitação dos operários envolvidos na atividade, por meio da apresentação de guias de participação em cursos e treinamentos. Um instrumento adotado em contrato é a realização de visitas periódicas para inspeção e realização de palestras educativas com profissionais formados em engenharia de segurança ou outra atividade afim, devidamente registradas e documentadas.

Por fim, o sucesso das ações de segurança depende também da conscientização de sua importância por parte dos usuários do imóvel, não necessariamente conhecedores do assunto. Por isso, é interessante a participação ativa e conjunta do pessoal da fiscalização e da empresa executante no sentido de manter os usuários constantemente informados a respeito das áreas interditadas, horários de liberação para usos diversos (abertura de janelas, por exemplo), entre outras, o que é realizado por meio de memorandos entregues nas unidades e fixados em locais de passagem intensa de pessoal.

Aspectos diversos relacionados ao comportamento dos funcionários também são explicitados nesse tópico, como recomendações (passível de advertência, seguida de suspensão e expulsão da obra) para realização de conversas com som alto ou palavras de baixo calão, proibição de refeição dos funcionários fora do local determinado, irrestrita permissão de permanência na obra de pessoas que causem qualquer tipo de transtorno ou constrangimento, conforme critério de julgamento da fiscalização ou do condomínio, entre outras ações.

Finalmente, quanto aos aspectos de higiene, no contrato são definidos locais para asseio e descanso dos operários durante a jornada de trabalho, bem como as suas condições de apresentação (fardamento, identificação) e conduta.

\subsubsection{Fiscalização}

Conforme melhor detalhado no item 4.3, as atividades de controle das ações durante a obra são elementos imprescindíveis da sua gestão, e envolve o acompanhamento tecnológico e operacional da obra. A fiscalização pode ser efetuada por empresa 
especializada, por usuário técnico do condomínio, ou até mesmo funcionários, a depender da necessidade de cada caso.

Em todas as situações é importante que sejam previstos em contrato a autonomia de decisão da fiscalização, os seus responsáveis, e os critérios básicos de aceitação e julgamento. Esse aspecto é ratificado também por Attalla e Hegazy (2003), que recomendam ainda que as atividades de fiscalização sejam previamente discutidas com as equipes de operação e manutenção futuras da edificação, além dos usuários, para assegurar o adequado desenvolvimento dessas ações.

\subsubsection{Garantias e responsabilidades}

De acordo com o descrito no Item 4.1.1.5, o Código Civil Brasileiro, no seu artigo 1245 , estipula que as empresas construtoras respondem pela segurança e solidez (ou qualquer defeito ou imperfeição que impeça o seu normal funcionamento, segundo interpretação doutrinária) da obra decorrente de falhas comprovadamente ocorridas durante os primeiros cinco anos da edificação, tendo o condomínio um prazo de 20 anos para reclamar judicialmente antes da sua prescrição.

Nesses termos, por analogia pode-se entender que as empresas de manutenção têm também o mesmo nível de responsabilidade sobre as áreas trabalhadas durante o período. Por conta disso é interessante ratificar em contrato que os preceitos contidos no artigo 1245 do Código Civil se aplicam à obra em questão, assim como deve ser exigida a apresentação da Anotação de Responsabilidade Técnica (ART) da obra assinada pelo seu representante técnico legal.

Assim como ocorre em edificações recém-concluídas e entregues para os usuários, é recomendável que seja prevista no contrato a entrega, no final dos serviços, de um relatório técnico (do tipo "As Built"). Esse documento de entrega da obra é imprescindível para esclarecer de forma precisa a todos os envolvidos quais as atividades executadas naquela intervenção, servindo, assim, como um elemento comprobatório quanto à extensão da garantia dada pelo serviço.

É necessária ainda a elaboração de um manual de operação, uso e manutenção correspondente às áreas onde ocorreram as intervenções. Nesse documento são descritos 
procedimentos executivos, prazos, amostragem e materiais a serem adotados durante as atividades futuras de manutenção necessárias para o condomínio.

Outra condição importante a ser discutida e esclarecida antes do início das obras se refere à assistência técnica de serviços que deve ser efetuada após a entrega final, que pode contemplar a realização de visitas periódicas de técnicos da empresa executante, pagas, por exemplo, com parte dos valores retidos durante a obra, naturalmente acrescidos das devidas correções monetárias.

No tocante às responsabilidades trabalhistas, conforme anteriormente comentado, é fundamental que fique claro no contrato que não cabe ao condomínio assumir qualquer tipo de ônus dessa natureza, salvo nos casos em que o mesmo seja o contratante direto da mãode-obra ou quando não cumpra alguma das suas responsabilidades contratuais (recolhimento de tributos, pagamentos etc.). Esse cuidado é importante especialmente pelo fato do condomínio responder solidariamente pelos problemas ocorridos na obra.

\subsubsection{Multas e sanções}

Como ocorre em qualquer tipo de relação comercial, antes do seu início são definidas as penalidades decorrentes do não cumprimento das responsabilidades por quaisquer das partes envolvidas. Desde que sejam previamente acordadas, essas penalidades podem ser desde simples advertências até a rescisão contratual.

A experiência mostra que um dos grandes problemas enfrentados em obras de recuperação de fachadas é o não cumprimento dos prazos de conclusão, devido ao surgimento de dificuldades não previstas inicialmente e a erros oriundos da atividade de programação. A indefinição e falta de precisão de aspectos diversos contratuais (quantidades, procedimentos executivos etc.) é uma das principais razões alegadas pelas partes para os atrasos recorrentes nas obras, causando transtornos diversos, especialmente para os usuários.

Assim, de forma preventiva podem ser estabelecidas no contrato sanções para esses tipos de problemas, os quais, em geral, representam perdas percentuais dos valores pagos nas medições, e aumentam de forma gradativa conforme o tempo de atraso. Esse tipo de 
ação preventiva é citada como recomendável também por Attalla e Hegazy (2003) em estudo de caso de manutenção realizada em escola na cidade de Ontário (Canadá).

As infrações de ordem técnica, como a não aprovação de serviços executados, ou mesmo de materiais já aplicados, por se tratarem de elemento essencial para o bom desempenho do serviço, não são admissíveis, de forma que o contrato deve prever a necessidade de remoção e substituição de trechos da obra identificados e comprovados pela fiscalização como defeituosos, sem custos para o condomínio ou contratante.

Caso o mesmo seja responsável pela aquisição e fornecimento de materiais, cabe-lhe o ônus da recuperação, se for comprovada a falha do componente. Entretanto, se o defeito estiver relacionado com o processo produtivo, a empresa executante deve providenciar a aquisição de material suplementar, ou pagamento da quantia correspondente em dinheiro, descontado na medição seguinte.

Quanto aos aspectos de segurança, cabe à fiscalização julgar o risco causado pelo descumprimento de alguma das diretrizes estabelecidas, de modo que os operários fiquem sujeitos a advertências, suspensões e, caso necessário, expulsão.

Por outro lado, é importante que sejam também preservados em contrato os direitos da empresa executante em relação às responsabilidades do condomínio (contratante). Como toda relação contratual, devem também ser explicitadas as condições necessárias para o seu rompimento sem prejuízo das partes, ou para os casos de rescisões decorrentes de decisões unilaterais, sujeitas a litígio.

\subsubsection{Condições gerais}

Como se pode observar, várias são as possibilidades de ocorrências em serviços dessa natureza, de modo que é praticamente impossível a previsão de todas as questões circunstanciais. Assim, é interessante o contrato apresentar um item correspondente a assuntos gerais que podem não estar diretamente relacionados a nenhum daqueles itens já comentados ao longo do presente tópico.

Um aspecto importante é a definição das condições mínimas para o início dos serviços e contagem dos prazos. Motivada pela ânsia por parte do condomínio em ver iniciadas as frentes de serviços após a conclusão de todos os passos já citados, pode 
acontecer a insistência das empresas executantes, e concordância do contratante, da partida da obra com a mobilização de equipamentos, funcionários, ferramentas em quantidades inferiores àquelas previstas na programação. Em virtude disso, é natural que ocorram atrasos e complicações diversas para o cumprimento das exigências contratuais estabelecidas.

Outra ação interessante a ser realizada previamente é a investigação, registro e documentação das condições de conservação dos elementos de apoio para os balancins (pavimentos de cobertura e térreo, a depender do tipo de equipamento) e também das edificações vizinhas. Uma vez avaliadas essas condições, preferencialmente ilustradas por meio de fotografias, pode-se estabelecer em contrato a exigência de vistorias, no final da obra, aos locais citados para avaliação dos danos eventualmente causados e as responsabilidades para os devidos reparos julgados necessários.

As condições intrínsecas desse tipo de serviço, que possui grande número de pessoas envolvidas, mesmo que indiretamente, como são os usuários do prédio, demandam da empresa executante a permanência em todo tempo de profissional habilitado responsável pela condução operacional da obra, além, evidente, da presença constante de engenheiro civil responsável técnico. Assim, cabe a inclusão no contrato da exigência com relação à presença desses profissionais na obra, em períodos de tempo pré-definidos em comum acordo, a fim de que as ações corretivas necessárias ao andamento da obra no seu dia a dia sejam implementadas com a agilidade requerida.

Por fim, considerando a imperativa necessidade de registro e documentação das atividades ocorridas é importante o estabelecimento em contrato da exigência de diário de obra, preenchido diariamente e assinado pela empresa executante, fiscalização e condomínio. Esse documento tem importância significativa para a avaliação e comprovação das ações realizadas durante o desenvolvimento do serviço e eventuais transtornos ocorridos. 


\subsection{Acompanhamento dos serviços}

Em qualquer ramo de atividades, as ações de acompanhamento do processo produtivo são essenciais para a garantia do cumprimento de determinações estabelecidas no planejamento. Com base nos parâmetros encontrados é possível se fazer ajustes para correções de desvios buscando a obtenção dos resultados previstos, ou até a sua melhoria.

As atividades de controle servem também para assegurar o correto cumprimento das ações estabelecidas nos projetos e nos laudos técnicos elaborados para cada caso. Como bem destaca Kumar (2005), um dos maiores desafios da indústria da construção é o controle de custos e prazos de execução. Um eficiente controle é necessário para que se consiga concluir obras e projetos dentro do prazo e a um custo pré-estabelecido.

O ciclo PDCA (Plan, Do, Check, Action), valioso instrumento de controle e melhoria de processo bastante utilizado nos estudos de sistemas de gestão da qualidade, representa de maneira evidente a necessidade de cada uma das etapas de gestão, destacando as atividades de acompanhamento como um dos elementos chave.

Quando são clara e corretamente pré estabelecidas, acordadas e documentadas, as atividades de controle servem como instrumento de apoio tanto para os fiscais quanto para os fiscalizados. Cabe destacar que os critérios de controle representam as metas a serem almejadas no processo, e cujo alcance significa o atendimento à finalidade desejada.

É intuitivo imaginar que a realização do controle das atividades de execução de uma obra envolve uma enorme variedade de situações. O grande número de frentes de serviço atuando simultaneamente, e o seu conseqüente contingente de pessoas, a diversidade de materiais e insumos utilizados, o incômodo causado nas áreas vizinhas (segurança, barulho, trânsito, sujeira, meio ambiente) são apenas alguns dos itens indispensáveis de atenção em atividades dessa natureza.

Em edificações já habitadas ou em uso, alguns dos aspectos mencionados tomam uma conotação ainda mais relevante, especialmente aqueles de ordem operacional, uma vez que os usuários se tornam participantes do dia a dia da obra, sofrendo diretamente as conseqüências da sua condução. 
Assim, no presente trabalho é apresentada de maneira distinta a atividade de controle tecnológico, que envolve apenas as questões técnicas (controle da produção e dos materiais), e controle operacional, o qual contempla o acompanhamento de prazos, medições, pagamentos, aspectos legais, de segurança, entre outros.

Interessante ressaltar que as ações de controle são entendidas, nesse estudo, como aquelas tomadas a partir do momento em que a empresa executante foi escolhida até o término dos serviços e ajustes dos acertos financeiros.

\subsubsection{Questões de ordem técnica}

As atividades de controle tecnológico da obra correspondem ao acompanhamento dos aspectos técnicos relacionados ao processo produtivo, que representa, portanto, a essência do trabalho de fiscalização. É inconcebível para o condomínio necessitar refazer serviços de manutenção corretiva em locais onde já ocorreram manutenções (preventivas ou corretivas), sobretudo caso sejam motivadas por novos defeitos ou falhas construtivas, além daqueles já cometidos durante a execução original do prédio.

Como já comentado, é imprescindível para o sucesso do controle que os critérios de exigência sejam previamente discutidos, acordados e documentados. A base para a definição dos referidos critérios, em especial nas questões técnicas, são as especificações estabelecidas em normalização técnica nacional e em literatura de referência. Os valores descritos nas normas regulamentadas têm valor de efeito jurídico, não se devendo prescindir do seu atendimento.

Em caso da sua inexistência, são também empregados valores apresentados em normas internacionais ou recomendações descritas em publicações técnicas. Essas situações tornam ainda mais premente a necessidade de análises conjuntas entre as partes envolvidas para definição dos critérios a serem exigidos.

Um mecanismo consagrado para a avaliação do desempenho de produtos ocorre por meio da realização de ensaios. Para o sucesso dessa ação são necessárias definições essenciais, como:

- Tipos e métodos de ensaio a serem utilizados, os quais devem apresentar dados que evidenciem a adequação ou não do parâmetro analisado. 
- Critérios de exigência baseados em parâmetros técnicos reconhecidos.

- Amostragem e local dos corpos-de-prova adotados como representativos do universo controlado.

- Entidades responsáveis pela realização dos ensaios, com confiabilidade metrológica analisada.

No caso das investigações realizadas em áreas de fachada, para os ensaios realizados "in loco" existem fatores operacionais que podem dificultar a sua realização, especialmente no que se refere ao acesso aos locais exatos dos testes.

Em virtude da eventual ocorrência de não conformidade dos resultados com as exigências estabelecidas são tomadas ações corretivas, as quais devem também estar claramente acordadas e documentadas.

Outro instrumento de acompanhamento bastante utilizado em obras são as fichas de verificação, que contém alguns parâmetros julgados importantes para a garantia de conformidade daquilo que se está avaliando. Essas fichas são preenchidas na obra e, a partir de parâmetros que, em alguns casos, estão contemplados na própria ficha, é alertada a necessidade de intervenção de caráter corretiva.

Como se pode perceber, faz parte da atividade de controle a adoção de medidas corretivas a serem tomadas caso sejam identificados desvios nos resultados ou análises realizados. Uma boa conduta de controle é aquela em que ambos os agentes (fiscal e executante) atuam em sintonia, cada um cumprindo as suas funções. Ou seja, ao fiscal compete identificar o problema e informá-lo, com a maior brevidade possível, ao executante, a quem cabe proceder às ações corretivas previamente estabelecidas.

Contudo, não são raros os casos de ações de fiscalização punitivas, em que as não conformidades são encontradas durante o serviço, porém apontadas apenas no momento da medição, exigindo maior quantidade de ajustes e retrabalho. Esse tipo de conduta pode causar um mal estar numa relação em si pouco amistosa, em decorrência do conflito evidente de interesses.

A confiança existente de lado a lado é importante para o sucesso dessa atividade, e só pode ser alcançada com o contato constante diário de ambas as partes. Isso corrobora 
com a necessidade indicada em contrato da presença em tempo integral na obra de um representante técnico da empresa executante, intermediando para os operários as intervenções sugeridas pela fiscalização. Ação recomendada por Attalla e Hegazy (2003) é a realização de reuniões quinzenais entre a equipe de construção, fiscalização e usuários para discussão dos serviços executados e esclarecimento das atividades de controle.

Importante destacar que, nos serviços executados em fachadas, há uma maior dificuldade de acompanhamento por conta das atividades serem realizadas em locais cuja adequada visualização é possível apenas no balancim. Quando existem diferentes frentes de serviço, algumas vezes atuando em andares elevados, a observação mais apurada do processo produtivo no local ocorre com menor intensidade do que em áreas internas, por exemplo, exigindo maior atenção e cuidado nas verificações.

Atitude também recomendada, quando possível, é a definição de um representante técnico, ou colegiado (comissão de reforma), formado por componentes do condomínio que apresentam alguma afinidade com as questões técnicas da obra, a fim de dialogar com a fiscalização, e eventualmente até com a empresa executante, para melhor entendimento do andamento dos serviços.

As ações de controle, uma vez entendidas também como elemento de referência para a tomada de decisão das intervenções corretivas, devem ser processadas (coleta, análise, retroalimentação) com velocidade compatível com o desenvolvimento da obra, sob pena de servirem apenas para efeito punitivo.

Isso também salienta a importância da presença sistemática da fiscalização, com maior nível de abrangência possível, atuante e pró ativa. O livro diário de obras é o documento onde são relatadas todas as ações corretivas apontadas na obra, as quais fazem parte também de relatórios periódicos (mensais) entregues pela fiscalização ao condomínio a respeito do andamento da obra.

O controle tecnológico das atividades pode ser separado em serviços relacionados especificamente com os materiais empregados, normalmente representados por ações tomadas logo no seu recebimento ou, obrigatoriamente, antes da sua liberação para uso, e ações relativas ao processo produtivo em si, muito atreladas à qualidade e capacitação da mão-de-obra. 


\subsubsection{Controle tecnológico - materiais}

Os materiais utilizados em obras de manutenção podem ser adquiridos tanto pela empresa executante quanto pelo condomínio, a depender do acerto contratual realizado. A razão pela adoção da segunda hipótese é evitar a tributação duplicada sobre o material, onerando mais a obra.

O rigor adotado nas atividades de controle dos materiais utilizados na obra varia de caso a caso, a depender do número de insumos envolvidos, quantidades utilizadas, entre outros. Em todos os casos, entretanto, quanto mais detalhada estiver a especificação dos materiais mais facilitada será a atividade de controle.

Uma prática considerada válida para reduzir os riscos quanto à não conformidade é a exigência de aquisição de produtos com fornecedores que apresentem certificado comprovado de qualidade, ou algo que o valha, salvo quando houver alguma impossibilidade. Trata-se de uma tendência natural da construção civil, que provavelmente será implementada com maior rigor em longo prazo.

Essa garantia não extingue a necessidade de avaliação do produto entregue na obra, mas reduz a possibilidade de aquisição, e eventual uso indevido, de materiais oriundos de fornecedores menos qualificados.

O controle efetivo de recebimento, considerada uma ação de curto prazo, é determinado conforme o tipo de material em questão. Em todos os casos é imprescindível que haja rastreabilidade dos lotes (número de série, data de fabricação etc.), os quais devem chegar à obra num prazo compatível entre o tempo necessário para a realização do ensaio e a sua efetiva utilização, período em que permanece estocado e identificado como não liberado.

Nas obras de fachada revestidas aderidos, foco do presente estudo, são utilizadas argamassas diversas, muitas delas adquiridas industrializadas, preparadas para uso após apenas a colocação de água, e eventualmente também de aditivos.

As argamassas mistas de cimento Portland utilizadas como emboço, massa única ou reboco podem ser avaliadas a partir de requisitos estabelecidos pela NBR 13.530 (ABNT, 1995b), que apresenta classificação de acordo com a resistência à compressão e à tração na 
flexão, densidade de massa (estado fresco e endurecido), coeficiente de capilaridade, retenção de água, cujos métodos de ensaio estão descritos em normas específicas.

Interessante notar que essas normas brasileiras, apesar de explicitarem classes, não as relacionam com a respectiva aplicação, o que impossibilita a determinação de critérios de aceitação para recebimento com base nas recomendações normativas, o que deve ser determinado pelo projetista responsável pelo serviço.

Outro aspecto não abordado claramente trata da amostragem para realização dos ensaios, nem para as argamassas industrializadas, e tampouco para aquelas que serão produzidas na obra.

As argamassas fabricadas na obra devem ter os seus critérios normativos avaliados previamente em laboratório, utilizando materiais e proporções indicados no procedimento executivo definido pelo projetista e explicitado no escopo dos serviços (item 4.2.3.5). A partir de um determinado volume produzido de argamassa $\left(30 \mathrm{~m}^{3}\right.$, por exemplo, ou $1.000 \mathrm{~m}^{2}$ aplicados de área) na obra, podem ser moldados corpos-de-prova para a realização de ensaios em laboratório, assim como é feito em peças de concreto fabricadas no canteiro.

Nas obras de manutenção em revestimentos aderidos, tipo placas cerâmicas ou placas de rocha, é comum o emprego de argamassas colantes industrializadas como elemento de ligação dessas peças à base. Tais argamassas são classificadas pela NBR14.081 (ABNT, 2004) conforme o tipo ( $\mathrm{ACl}, \mathrm{ACl}, \mathrm{ACl}$, ou especial - $\mathrm{E}$ ) e os seus respectivos usos. Os requisitos adotados são o tempo em aberto, a resistência de aderência nas condições de cura seca, submersa e em estufa, aos 28 dias, e o deslizamento, cada qual com critérios claramente definidos.

De cada lote (cujo tamanho pode ser acordado entre as partes ou, na sua ausência, correspondente à quantidade produzida na fábrica em 24 horas) é retirada uma amostra composta por $20 \mathrm{~kg}$ de material que, em geral, representa o peso de um saco para envio e análise em laboratório.

As placas cerâmicas também são bastante empregadas em obras dessa natureza, sendo regidas pela NBR13.817 (ABNT, 1997), que determina a sua classificação, requisitos e critérios. Assim como ocorre com as argamassas de emboço, nesse caso também não há uma relação entre alguns esses parâmetros e sua aplicação, o que dificulta uma análise 
normativa de aceitação. Os ensaios mais comumente adotados para os casos de fachadas são os de absorção de água, resistência ao gretamento, expansão por umidade e marca d'água, que podem ter critérios de aceitação pré acordados entre as partes.

A definição da amostragem pode ser efetuada de forma análoga à da argamassa colante, ou seja, para cada lote de placas (devidamente identificado) são retiradas placas aleatórias em quantidades definidas pela normalização para cada tipo de ensaio, que são encaminhadas para laboratório.

Outro insumo também utilizado é a argamassa para rejuntamento, cujas definições são relatadas na NBR 14.992 (ABNT, 2003a). Existem também critérios e requisitos (resistência à compressão, tração na flexão, variação dimensional, retenção de água, absorção de água por capilaridade e permeabilidade aos $240 \mathrm{~min}$ ) que estabelecem os limites representativos das classes ARI e ARII, cada qual com as suas respectivas descrições de uso. Cada lote, nesse caso, é representado por uma quantidade máxima produzida de 3 toneladas, sendo retirada amostra aleatória de $20 \mathrm{~kg}$ para envio ao laboratório.

Em todos os casos citados chama atenção a necessidade de se coordenar a atividade de controle com a programação de compras ou suprimentos. Uma vez que a maioria dos ensaios descritos demanda um prazo médio de 30 dias para a sua realização, é preciso que os materiais cheguem à obra com uma brevidade que permita a análise laboratorial sem prejuízo da produtividade da obra, dependente da sua liberação para uso.

Quando se trata da fabricação de argamassas na obra, além da própria argamassa produzida, é importante que sejam controlados os materiais empregados na sua confecção, em especial o cimento Portland, a cal hidratada e os agregados.

Não é prática comum em obras imobiliárias de médio e pequeno porte, como são classificadas a maioria das atividades de manutenção em fachadas, a realização de ensaios de comprovação das características do cimento Portland, a despeito da grande responsabilidade que o mesmo exerce nas propriedades das suas misturas. Isso se deve ao reconhecido eficiente controle de produção realizado pelas cimenteiras, gerando dispersões de resultados historicamente baixos.

Situação distinta ocorre no caso das cales, cuja grande quantidade de produtores espalhados pelo Brasil evidencia a heterogeneidade de matérias-primas e processos de 
produção entre os diferentes fornecedores. Trabalho apresentado por Priori Jr et al. (2006) exemplifica o problema descrevendo a variedade da qualidade das cales encontradas no estado de Pernambuco, e a sua influência significativa no desempenho da argamassa de revestimento.

Algumas vezes, dentro da indústria o produto cal para construção representa uma receita menos representativa em comparação com outros insumos fabricados (calcário para a indústria de tintas, siderúrgicas, estabilização de solos etc.), de modo que não são investidos recursos no seu controle interno.

A NBR 7175 (ABNT, 2003b) classifica as cales hidratadas, usualmente empregadas em argamassas, em CHI, CHII e CHIII, diferenciadas a partir de exigências químicas e físicas. Não há uma relação nessa norma do tipo de cal a ser utilizado com a sua aplicação, o que sugere que aquela mais pura e fina deve ser adotada preferencialmente para o uso em argamassas.

Por fim, a areia utilizada para argamassas também pode influenciar nas suas propriedades, de maneira que são realizados ensaios de caracterização granulométrica, para comprovação da adequação estabelecida na carta de dosagem, e também para identificação de outros parâmetros indesejados, como, por exemplo, a excessiva presença de material pulverulento.

Como se pode perceber, para efeito de controle, o maior número de insumos utilizados para a fabricação da argamassa na própria obra exige das equipes de produção e fiscalização maior atenção, além de maiores custos de ensaios.

Cabe ainda comentar que todos os materiais utilizados são também controlados quanto ao peso, volume, prazo de validade, acondicionamento dentro da embalagem (se for o caso), enfim, aspectos que possam influenciar no seu desempenho.

Um cuidado elementar e relevante é a conferência entre a especificação estabelecida em projeto e aquela apresentada pelo material em campo. Não é função do fiscal técnico julgar a correção dessa especificação com as prescrições normativas ou demais recomendações, que é discutido na etapa de projeto, durante a definição do escopo dos serviços. Lógico que, caso sejam encontradas inadequações, isso pode ser levado para discussão e para eventual alteração de produtos ou especificações. 


\subsubsection{Controle tecnológico - produção}

O acompanhamento do processo produtivo de uma obra é efetuado ao longo do seu desenvolvimento no dia a dia, em cada frente de serviço. Essa tarefa exige experiência e compreensão, por parte do fiscal, não apenas dos procedimentos pré estabelecidos para a obra, mas também das repercussões decorrentes de variações eventualmente surgidas no transcorrer dos serviços.

A construção civil é, em termos gerais, reconhecida como uma indústria marcada pela dificuldade de implementação de mudanças e novos conceitos. Com isso, é importante o poder de convencimento do fiscal junto aos representantes técnicos da empresa executante, ou mesmo junto aos operários, sob pena das ações recomendadas não serem adotadas sistematicamente, acarretando num maior retrabalho e maior possibilidade de serviços mal executados e não identificados.

A base para o acompanhamento da produção são os procedimentos executivos dos serviços previamente estabelecidos no escopo das atividades e documentadas no contrato. Esses procedimentos podem ser apresentados pela empresa executante ou pela gerenciadora, discutidos e acordados entre as partes. O rigoroso acompanhamento das recomendações previstas nesses procedimentos é uma das chaves para o sucesso da atividade.

A partir desses documentos é comum a elaboração de fichas de controle, compostas por itens de verificação, que facilitam o acompanhamento. Os fatores de análise podem ser mensuráveis, tais como, por exemplo, desaprumos ou desalinhamentos máximos admitidos, ou apenas "inspecionáveis" por meio de aspectos visuais qualitativos.

Também as normas referentes à execução dos serviços são adotadas como referenciais, em complemento aos procedimentos pré estabelecidos. Ambos, inclusive, devem estar compatíveis para evitar contradições.

As NBR 7.200 (ABNT, 1998), NBR 13.755 (ABNT, 1996) e NBR 13.739 (ABNT, 1996) estabelecem os procedimentos principais de produção recomendados para as argamassas de cimento utilizadas como emboço, reboco ou massa única, bem como critérios de aceitação diversos, referentes a parâmetros geométricos e mecânicos. 
Dentre os vários critérios descritos cabe destacar os níveis mínimos de resistência de aderência exigidos em ensaios de cargas aplicadas à tração direta, largamente empregados em obras de revestimento. É uma técnica com relativa facilidade de execução e resposta imediata, razões pelas quais é muito utilizada para a avaliação do desempenho de revestimentos.

Para a execução desse ensaio é efetuado corte no revestimento, normalmente por meio de serra copo ou disco de corte, até se atingir a base. Em seguida é colada, com resina, uma placa metálica à base, a qual é acoplada a um equipamento que imprime esforços de tração até que ocorra a ruptura. A carga máxima é dividida pela área de atuação do esforço para se obter a tensão de ruptura do revestimento, que deve ser superior aos valores estabelecidos na NBR 13.749 (ABNT, 1996), conforme a localização.

Tabela 12 - Limites de resistência de aderência à tração (NBR 13749, ABNT (1996)).

\begin{tabular}{|c|c|c|c|}
\hline & LOCAL & ACABAMENTO & Res. aderência (MPa) \\
\hline \multirow{4}{*}{ PAREDE } & \multirow{2}{*}{ INTERNA } & Pintura ou base para reboco & $\geq 0,20$ \\
\hline & & Cerâmica ou laminado & $\geq 0,30$ \\
\hline & \multirow{2}{*}{ EXTERNA } & Pintura ou base para reboco & $\geq 0,30$ \\
\hline & & Cerâmica & $\geq 0,30$ \\
\hline
\end{tabular}

O ensaio de aderência (ou arrancamento, como também é conhecido) apresenta uma dispersão considerada elevada de resultados, e também divergentes formas de interpretação, motivado por uma série de fatores, conforme comentado pela Prof ${ }^{\mathrm{a}}$ Mércia Barros (EPUSP) em artigo publicado na Revista Téchne ${ }^{37}$, e comprovado em trabalhos experimentais diversos, como o apresentado por Cunha Jr et al. (2006). Alguns dos fatores de influência no ensaio estão a seguir apresentados:

- Como o corte é realizado desde a superfície até a base, nos pontos de ensaio é verificada a resistência de cada uma das camadas, além da aderência entre as mesmas, de modo que há vários tipos possíveis de ruptura. Com isso, é importante separar a análise dos valores encontrados e a forma de ruptura ocorrida.

\footnotetext{
${ }^{37}$ Revista Téchne. Como verificar a aderência de argamassas. n.88, jul. 2004, p42-45.
} 
- Os tipos de ruptura são um indicativo do elo frágil do sistema naquele ponto, que pode ser oriundo da aplicação de um material inadequado ou da aplicação inadequada do material, ou seja, falha de produção.

- O tamanho do corpo-de-prova é pequeno em relação ao todo (placas quadradas com $5 \mathrm{~cm}$ ou $10 \mathrm{~cm}$ de lado, ou circulares com $5 \mathrm{~cm}$ de diâmetro), possibilitando a realização do ensaio em um local que pode não ser representativo do conjunto, a depender da amostragem e do trecho avaliado.

- A NBR 13.749 (ABNT, 1996) prevê a realização de um pano de ensaio, composto por seis pontos de arrancamento, para cada $100 \mathrm{~m}^{2}$ de área executada, a critério da fiscalização. A menos em locais com alguma dúvida de comportamento, esse número pode ser considerado excessivo, não apenas em virtude dos custos, mas principalmente em virtude das dificuldades operacionais relativas à sua execução. $A$ depender do caso, a separação da fachada em panos conforme a sua orientação (norte, sul, leste e oeste), número de pavimentos, área bruta, tipo de acabamento podem servir como orientativo para definição de amostragem.

- Os trabalhos em fachada, em virtude das dificuldades já anteriormente mencionadas, são de difícil controle apurado durante uma obra, em comparação com serviços realizados em áreas internas. Além disso, estão sujeitos a influências externas das mais diversas naturezas, tanto durante a produção como ao longo de sua utilização, como a incidência de sol e vento, chuva e temperatura. Assim, as variações nos fatores humanos (mão-de-obra) e ambientais podem provocar desempenhos distintos do revestimento ao longo da fachada, exigindo maior atenção nas operações de controle.

- Existem alguns aspectos operacionais que dificultam a realização do ensaio, o que contribui para as deficiências na sua análise. Para possibilitar o adequado posicionamento do operador do equipamento de ensaio, muitas vezes é necessária a presença de algum tipo de aparato, como o balancim, no exato local do ensaio. Como os ensaios em argamassa à base de cimento exigem uma brevidade mínima de aplicação (14 a 28 dias, pelo menos), o tal aparato tem de estar posicionado no local no momento da sua realização, parando as demais atividades produtivas. 
- Outra dificuldade operacional do ensaio, especialmente agravada no caso de edificações em uso, é a necessidade de garantia de segurança aos envolvidos. Uma vez que uma placa metálica é colada à base, seguido do seu arrancamento somente após a cura da resina, é preciso que, durante todo o tempo, a área sob o pano da fachada seja isolada em todos os momentos do ensaio, causando transtornos de funcionalidade e produtividade dos serviços.

- Ainda existe no meio técnico certa indefinição quanto ao método utilizado para a realização do ensaio, com especial destaque para as variáveis referentes ao tamanho e geometria das amostras, e ao tipo de corte do revestimento (a seco, com disco de corte, ou úmido, com os materiais ainda em estado fresco). Em trabalho apresentado por Carasek (1996) são discutidos estudos experimentais comparando resultados conforme a metodologia utilizada e também entre os modelos indicados por normas técnicas de países diversos.

No atual momento, atendendo solicitação do Consitra, o NUTEA (Núcleo de Tecnologia das Argamassas e Revestimentos) da Universidade Federal de Goiás, coordenado pela Prof ${ }^{\mathrm{a}}$ Helena Carasek, está desenvolvendo estudo para avaliação das citadas variáveis encontradas no ensaio de aderência.

Outro teste prático de rápida e simples execução, porém também de baixa precisão, é o ensaio de risco por elemento perfurante (prego, por exemplo) em argamassas. Essa avaliação, que pode ser contemplada na ficha de verificação dos serviços, possibilita a investigação empírica da capacidade resistente superficial da argamassa, grandemente influenciada pelas operações de acabamento. Caso a superfície, durante o riscamento, apresente um aspecto friável ou pulverulento, faz-se necessária uma investigação mais detalhada por meio do ensaio de aderência.

Uma alternativa para investigação da aderência superficial da argamassa é a realização do próprio ensaio de arrancamento, porém sem a realização do corte. Com isso, é possível uma avaliação mais detalhada da resistência superficial da argamassa.

A realização dos ensaios de aderência, como se pode perceber, apresenta uma boa aplicabilidade em obra. Entretanto, é necessária ainda uma maior definição normativa 
quanto aos critérios de amostragem e aceitação. Nesse sentido, são a seguir apresentadas algumas propostas, a serem avaliadas de acordo com a estrutura disponível na obra:

- Realização de, pelo menos, 2 panos de ensaio, cada qual composto por 3 pontos de arrancamento, em cada balancim. Quando possível, escolher pavimentos diferentes para os ensaios em cada balancim. Esses ensaios devem ser realizados em pontos afastados, no mínimo, de $50 \mathrm{~cm}$ das quinas e aberturas existentes.

- Dentre os 3 pontos analisados, no mínimo 2 devem apresentar valor superior a $0,30 \mathrm{MPa}$, não sendo permitido valor individual inferior a 0,20MPa.

- Caso os valores obtidos estejam abaixo dos patamares citados, deve ser realizada nova bateria de ensaio nos pavimentos imediatamente superior e inferior, adotandose os mesmos critérios para aceitação.

Importante considerar que a proposta apresentada deve ser avaliada caso a caso, a fim de atender às particularidades inerentes a cada um.

O ensaio de inspeção por percussão, já discutido no Item 4.1.1.2, também é aplicável durante a produção, uma vez que pode indicar a ocorrência de locais com deficiência de aderência por meio de uma avaliação não destrutiva. Contudo, pelo fato de ter uma baixa precisão, é utilizado de forma complementar a outras avaliações, cabendo, de todo modo, a explicitação da sua obrigatoriedade no procedimento executivo da obra.

Não apenas com ensaios é realizado o controle do processo produtivo da obra. Em se tratando da argamassa de emboço fabricada em obra, por exemplo, antes de liberá-la para o uso é imprescindível uma avaliação dos parâmetros da dosagem ou proporção proposta entre os materiais.

A NBR 13755 (ABNT,1996) apresenta um intervalo orientativo para as argamassas de fachada, com traços em volume aparente variando de 1:0,5:5 a 1:2:8 (cimento Portland: cal hidratada: areia média úmida). Esses parâmetros, como já mencionado, devem ser tomados apenas como orientativos, pois há outros aspectos que influenciam no comportamento em uso da argamassa, como: condições de base e do ambiente, granulometria da areia, tipo de qualidade da cal hidratada, espessura da camada, entre outros. 
A mistura dos constituintes das argamassas, tanto daquelas fabricadas na obra quanto das industrializadas, também tem repercussão no seu comportamento, sendo importante o controle. Nesse aspecto, é importante que a mistura seja realizada, preferencialmente, de forma mecânica, utilizando-se, para isso, de argamassadeiras de eixo horizontal, a fim de garantir maior homogeneidade. A quantidade de água também deve ser monitorada, o que pode acontecer a partir de dosagens entregues aos operários responsáveis pela mistura. O tempo da mistura é outro fator que precisa ser previamente estabelecido para facilitar as atividades de produção e controle.

Alternativa eficiente para a mistura dos componentes da argamassa é a utilização de hélices acopladas a furadeiras portáteis, que possibilita a sua preparação até mesmo no próprio balancim, em procedimento similar a uma batedeira de bolo. Como apoio para a argamassas são usadas cubas plásticas de tamanhos variados (também conhecidas como "masseiras").

O cumprimento do prazo estabelecido para a conclusão dos serviços, como já previamente comentado, é um problema recorrente em obras de manutenção de fachadas, especialmente naquelas em que a programação das atividades for mal realizada. Com isso, ao longo da obra, é muito comum a necessidade, por parte do construtor, de se tentar adiantar ao máximo os serviços, em alguns casos em detrimento dos prazos para liberação estabelecida previamente. É importante atenção da equipe de fiscalização no tocante a esses prazos, cujos não cumprimento podem comprometer o desempenho técnico da obra, principalmente na medida em que se vai aproximando do seu término.

Por fim, ainda no campo dos prazos, é interessante que seja acompanhado o tempo máximo de utilização das argamassas à base de cimento que, em condições normais, não deve exceder a 2 horas desde o momento da adição da água de amassamento.

Outro mecanismo eficiente para se obter um adequado processo produtivo é a realização de treinamentos com a mão-de-obra, o que não é de responsabilidade da fiscalização. Entretanto, a apresentação de certificados de participação em treinamentos diversos, mesmo que internos da empresa executante, pode servir à fiscalização como critério de seleção ou aceitação de operários para a execução de determinados serviços. 
A importância do treinamento é observada na recomendação existente na NBR 5674 (ABNT, 1999) para realização dessa atividade com os recursos humanos envolvidos no serviço, e especialmente no caso de manutenção em fachada, por se tratar de procedimentos com particularidades diferenciadas em relação àquelas normalmente exercidas numa obra "nova".

\subsubsection{Questões de ordem operacional}

As questões operacionais relacionadas com obras de manutenção em revestimentos de fachada são entendidas nesse trabalho como aquelas atividades que estão à margem do desempenho técnico final da obra, mas conduzem o andamento dos serviços ao cumprimento das obrigações contratuais de prazos, pagamentos e segurança dos sujeitos envolvidos, além de reduzir a possibilidade de ocorrência de qualquer tipo de transtorno, durante e após a conclusão do serviço.

Existem três vertentes principais de controle operacional dos serviços, a reboque das quais vêm as demais atividades, que são: o acompanhamento dos prazos e suas repercussões; a precaução quanto a problemas futuros fiscais e trabalhistas; e a prevenção dos distúrbios diversos aos usuários do imóvel.

Para todas essas atividades é imprescindível manter o usuário sempre bem informado das ações a serem tomadas para avaliação das suas reações, como descrevem Barrientos e Qualharini (2004).

\subsubsection{Acompanhamento dos prazos e suas repercussões}

O acompanhamento dos prazos previstos para a obra é realizado por meio da comparação entre o cronograma físico inicialmente proposto e o real andamento da obra. A partir do levantamento dessas informações pode-se fazer uma estimativa da execução com base na produtividade alcançada na obra. Como salienta Kumar (2005), o adequado planejamento serve como parâmetro de comparação durante o controle, uma vez que um bom acompanhamento de prazos começa com um eficiente e confiável desenvolvimento da programação de cada uma das atividades envolvidas no projeto.

Trabalho discutido por Yiu et al. (2002) salienta a necessidade desse tipo de acompanhamento, sendo apresentado estudo de caso correspondente a substituição do 
mastique utilizado nas juntas de movimentação da fachada de edifícios residenciais na cidade de Hong Kong, cujos prazos excederam em $25 \%$ o que havia sido previsto.

No artigo apresentado por Gao et al. (2002) é apresentado resultado de pesquisa efetuada junto a gerentes de projetos de empresas diversas que destaca o problema da dilatação dos prazos de conclusão das obras, em relação ao originalmente concebido, superior para os casos de serviços de pequeno porte em comparação com obras de grande porte (obras novas, por exemplo).

Attalla e Hegazy (2003) discutem, em trabalho de controle das atividades de manutenção em obras, o sucesso da realização do acompanhamento periódico do cronograma por meio da apresentação de gráficos de barra comparativos entre o planejamento previsto e o real executado, além do percentual ainda a ser realizado em cada atividade. Com isso, é possível até mesmo efetuar correções de rumos a partir dos desvios encontrados.

A adequada velocidade com que os dados são coletados, avaliados e repassados à unidade produtiva é essencial para um correto cumprimento da atividade, associado à vontade (forçada ou não) da empresa executante de honrar os seus compromissos. Por mais eficiente que seja esse acompanhamento, à fiscalização não compete a execução propriamente dita das atividades, mas sim apontar os desvios e indicar alternativas para correção dos rumos.

Em trabalho apresentado por Kumar (2005) é salientada a importância da atualização dos prazos conforme a evolução da obra, o que obriga um fluxo constante de informações para que as deficiências possam ser analisadas e processadas, permitindo intervenções eficientes.

Parker (1994) destaca que os dados utilizados para a elaboração do orçamento devem ser completos o suficiente para permitir controle eficiente, uma vez que esse instrumento é utilizado como referência tanto para a tomada de decisões como para as atividades de controle.

O conhecimento da produtividade dos serviços alcançada efetivamente na obra possibilita a previsão dos prazos e da necessidade, por exemplo, de eventuais ajustes no número de funcionários e equipamentos para o cumprimento das metas. Uma das unidades 
de medida da produtividade é a relação entre o número de operários que realizam determinado serviço numa unidade de tempo qualquer (hora, dia, semana), em relação à área executada. A partir da quantidade de área ainda prevista a ser executada, com o índice obtido pode-se determinar a quantidade de dias ou operários para a sua conclusão, desde que, naturalmente, sejam realizadas apenas as mesmas atividades.

Percebe-se, com isso, que os ajustes podem ser efetuados dentro de uma periodicidade que seja a mais adequada às necessidades da obra. Caso as recomendações de alterações consigam corrigir a produtividade a ponto de manter a programação inicial das atividades macro, não são necessárias maiores precauções, caso contrário é importante que o novo cronograma seja discutido entre a fiscalização e a empresa executante para apresentação e aceitação do condomínio.

A apresentação de um eventual novo cronograma físico ao condomínio é essencial, pois permite aos seus responsáveis ajustar as previsões de compras dos materiais, se for 0 caso, e também pode sugerir a aplicação no mercado financeiro dos recursos disponíveis. Além disso, torna possível a informação aos demais usuários do imóvel a respeito dos novos prazos e suas repercussões nas áreas sociais do edifício (interdições, ruídos, sujeira).

A fim de evitar a ocorrência constante desse problema de atraso nas obras, é importante a previsão de sanções em contrato, que podem até ser aplicadas em datas marco ao longo do serviço, e não apenas no seu término. A previsão e o rigor no cumprimento das sanções desde o início dos serviços, que pode até ser explicitada de forma indireta como um incentivo no caso do alcance das metas, favorece o cumprimento dos prazos. Uma vez que é natural a ocorrência de alguns elementos imprevistos no início das obras, as sanções ou incentivos podem ser propostos com rigor crescente à medida que o serviço vai chegando ao seu final.

Outra prática interessante para evitar o atraso para a conclusão da obra é a vinculação do início dos serviços à montagem de todos os equipamentos previstos, especialmente balancins e telas de proteção. Em alguns casos, na ânsia de ver os trabalhos iniciados, o condomínio acaba permitindo que a obra comece mesmo sem todos os equipamentos prontos, o que faz com que os serviços já partam com uma produtividade aquém da esperada, alterando o cronograma antes mesmo do seu início. 
A elaboração de relatórios semanais de produtividade com previsão de conclusão das atividades macro é um mecanismo eficiente para avaliação do andamento da obra, possibilitando ajuste permanente de rumos. Esses relatórios são discutidos entre a fiscalização e a empresa executante para tomada das ações necessárias. A partir do desenvolvimento das atividades e acompanhamento de outros serviços podem então ser realizadas reuniões também com representantes do condomínio para avaliação do andamento da obra.

A base dos dados levantados para a análise dos prazos é obtida a partir da medição das quantidades de serviço executadas no período. A depender do tipo de contrato, é a partir das medições que são definidos os pagamentos a serem efetuados à empresa executante.

Assim, é prática recomendada que a atividade de medição dos quantitativos seja realizada em conjunto entre a fiscalização e a empresa executante, reduzindo a possibilidade de contestações diversas. Nos casos em que os pagamentos sejam realizados com base nas quantidades executadas, é importante que fique claramente estabelecido entre as partes que não serão admitidas alterações nos valores totais. Ou seja, no final a soma das quantidades parciais deve corresponder ao total previsto em planilha, a fim de se evitar o acúmulo de eventuais erros ocorridos ao longo das medições. Para evitar esse problema, as medições podem ser efetuadas a partir de valores percentuais dos serviços concluídos, e também se recomenda que sejam realizadas medições acumuladas das atividades.

Existe a possibilidade de se acompanhar o andamento dos serviços com base nos custos apresentados na planilha orçamentária. Nesse caso são normalmente avaliados os pesos percentuais dos valores já realizados pela empresa executante, que possibilita a previsão para a conclusão dos serviços. Essa prática é utilizada, muitas vezes, quando o pagamento dos serviços ocorre a partir das quantidades medidas executadas, situação em que é interessante para o condomínio avaliar o percentual de valores pagos em relação ao que foi efetivamente executado.

Para evitar um descontrole da saída de recursos, há contratos que prevêem uma limitação de pagamento por medição de acordo com o teto estabelecido no cronograma físico financeiro. Caso a quantidade executada em determinada medição represente um 
valor que ultrapasse a previsão descrita no cronograma, o excedente é pago gradativamente nas parcelas seguintes, desde que o evento não torne a acontecer.

Um assunto importante a ser previamente estabelecido é o valor referente à mobilização e desmobilização de pessoal, materiais e equipamentos na obra. O pagamento desses itens é realizado no início e final dos serviços, podendo esse item ser inserido como verba de forma discriminada dos demais serviços na planilha orçamentária, permitindo a sua previsão e pagamento sem maiores contestações.

Cabe salientar que o gerenciamento e o controle de prazos e custos de uma obra são atividades distintas, conforme aborda Parker (1994). O gerenciamento corresponde às decisões tomadas pelos envolvidos para se chegar a um determinado custo na obra, enquanto o controle envolve o acompanhamento das atividades com o objetivo de checar o desempenho financeiro e regular os serviços visando o custo estimado.

É preciso que fique claro que as atividades de acompanhamento de prazos por parte da equipe de fiscalização devem ser avaliadas e interpretadas pela empresa executante como um agente que possibilite a correção de rumos e a implementação de melhorias ao processo produtivo. Caso encarado apenas como mero objeto de controle, passa a tomar um cunho muito mais punitivo do que agregador.

\subsubsection{Precauções quanto a problemas futuros fiscais e trabalhistas}

O controle dos aspectos legais que cercam a realização da obra é outra atividade de gerenciamento essencial para o seu sucesso. Assim como acontece nas demais atividades de controle já discutidas no presente trabalho, e com especial relevância nesse caso, é fundamental a explicitação das exigências previstas no contrato, que é o principal instrumento de apoio e cobrança.

Desde a época da escolha da empresa executante, os critérios estabelecidos para a habilitação, já discutidos no Item 4.2.2, servem como uma filtragem. Entretanto, a efetiva cobrança para apresentação da documentação estabelecida deve ser realizada de forma rigorosa já no primeiro pagamento dos serviços, sendo uma coisa vinculada à outra. 
O pagamento da primeira parcela pode estar também vinculado à apresentação do CEI (Cadastro Específico do INSS) da obra, cuja matrícula depende da apresentação da cópia da Anotação de Responsabilidade Técnica (ART) assinada pelo responsável técnico da empresa executante, do comprovante de inscrição no CNPJ, do projeto devidamente aprovado pelo CREA, e do alvará de licença para a construção e outros que se fizerem necessários.

Cabe destacar que existem duas formas diferentes de obras de manutenção em fachadas em edificações habitadas ou em uso: aquelas que têm função exclusiva de manutenção, mantendo a estética original do prédio, que pode ser classificada como reforma, e aqueles em que ocorrem alterações na forma ou na composição arquitetônica original do imóvel, classificada nesse trabalho como "retrofit", que exige autorização especial por parte dos agentes competentes (prefeituras, IPHAN, etc.).

O cumprimento das exigências contratuais fiscais e trabalhistas pode ser também vinculado ao pagamento das parcelas ao longo do desenvolvimento dos serviços. Nesses casos, é exigida a guia de comprovação do recolhimento (GPS, GFIP) ao INSS e FGTS dos funcionários vinculados à obra (cujos nomes estão registrados na folha de ponto, diariamente assinada por cada um).

\subsubsection{Prevenção dos distúrbios diversos aos usuários do imóvel}

Por fim, outra atividade de acompanhamento a ser desenvolvida pela fiscalização trata do controle quanto à ocorrência de distúrbios diversos à boa ordem dos serviços, que envolve principalmente aspectos de segurança pessoal e patrimonial.

Conforme já anteriormente comentado, as obras de engenharia apresentam níveis de risco mais elevados em relação a outras indústrias, o que é ainda agravado nos casos de serviços executados em fachadas de edificações já concluídas. São passíveis de riscos e, portanto, carentes de cuidados, os operários da obra, os usuários do imóvel (proprietários, locatários, funcionários), transeuntes, e aqueles que utilizam as edificações vizinhas.

Um elemento chave de avaliação trata do balancim a ser utilizado para a produção e acesso dos operários nas áreas de serviço. Por isso, pode-se exigir a apresentação à 
fiscalização, antes da montagem, do cálculo de comprovação de capacidade e limitação de peso máximo de cada elemento assinado por profissional competente e habilitado no CREA.

Em obras motivadas pela ocorrência de quedas de revestimentos verticais aderidos de fachadas, os balancins podem ser também protegidos com algum tipo de aparato na sua parte superior.

Para proteção dos usuários da edificação, é necessário que sejam instaladas bandejas, com altura mínima de 2,5 metros acima do piso do pavimento térreo e largura adequada para garantir a segurança daqueles que eventualmente necessitem trafegar naquele local. Nas laterais da bandeja são fixados tapumes ou faixas de sinalização para evitar a passagem de pessoas. A sua remoção ocorre apenas após a conclusão de qualquer tipo de serviço no trecho de fachada correspondente.

Outro item de segurança muito importante, especialmente quanto às áreas externas do prédio (edificações vizinhas, pedestres e automóveis na rua) é a colocação das telas de nylon em toda a extensão da fachada onde estejam sendo realizados os serviços.

A quantidade de tela prevista para a obra é função do prazo e produtividade prevista do serviço, do tipo de material empregado (e sua durabilidade), da geometria da fachada, da programação das frentes de serviços e, até mesmo, das condições ambientais, especialmente a existência de ventos intensos e chuva.

Para que possa cumprir adequadamente a suas funções, a tela precisa cobrir toda a área de atuação das atividades, inclusive contemplando uma sobra para cada lado do balancim, permanecendo íntegra durante o período. Não são raros os casos em que ocorrem erros na previsão das quantidades das telas e rasgos ao longo da altura do prédio, demandando o seu reparo.

Cuidado importante para evitar que ocorram rasgos na tela é a amarração inferior com corda em um ponto fixo, e também em pontos laterais em pavimentos alternados. Em muitos casos isso demanda uma autorização por parte dos usuários para instalação de um tipo de apoio fixo para as cordas no pavimento, preferencialmente posicionada em alguma área social. Outro cuidado é a verificação da existência de elementos salientes no balancim (sobra de sarrafo de madeira, ponta metálica de andaime etc.) que podem provocar dano à tela quando da sua movimentação. 
Com relação aos operários, é imprescindível a exigência rigorosa do uso dos Equipamentos de Proteção Individual (EPI's), sendo interessante a adoção de sanções gradativas para punições (advertência, suspensão, demissão), que podem ser determinadas não apenas pela fiscalização, mas também pela empresa executante.

No caso específico dos trabalhos suspensos alguns cuidados podem ser salientados, como a necessidade de duas cordas com apoios independentes para a fixação dos cintos de segurança dos operários. Os cintos devem ser do tipo pára-quedista, também com duas cordas independentes para permitir a sua locomoção sempre segura ao longo do balancim.

Uma prática interessante adotada pela fiscalização é a solicitação de vistorias periódicas para avaliação e aprovação das condições de trabalho, pela Delegacia Regional do Trabalho (DRT), em uma periodicidade pré estabelecida (a cada três meses, por exemplo). Tal exigência pode ser feita também antes do início dos serviços, vinculando a liberação do pagamento da primeira medição à sua comprovação.

Outra prática importante recomendada é a discussão na obra da organização do canteiro, que nesses casos se confunde com áreas sociais do prédio, estacionamento, entrada de pessoas etc. O objetivo dessa organização é avaliar os locais mais convenientes para permitir a passagem e o acesso de pessoas, bem como o armazenamento dos materiais de consumo da obra.

Importante destacar que essa discussão deve contemplar todo o período de realização da obra, uma vez que é natural a ocorrência de alterações de acordo com o desenvolvimento do serviço e possibilidades de liberação das áreas.

A partir da definição da organização do canteiro é possível o estabelecimento de áreas consideradas de risco, as quais são delimitadas e têm o seu acesso devidamente controlado.

Um aspecto ainda de segurança a ser discutido trata da previsão de proteção das janelas e esquadrias diversas das unidades privativas e comuns. Desde a discussão do contrato pode ser prevista a colocação de algum tipo de aparato de proteção por meio de grades móveis de madeira com tela ou compensado, por exemplo, para evitar a ocorrência de danos, assim como deve estar declarada a responsabilidade (ônus) decorrente da necessidade de um eventual reparo. 
Para as esquadrias do tipo projetante é preciso que sejam distribuídos documentos aos usuários informando da necessidade da sua interdição enquanto estiverem sendo realizadas atividades nos seus respectivos panos de fachada. Esse documento informativo permite também ao usuário tomar providências quanto à privacidade dos espaços internos da sua unidade privativa.

Outra questão de privacidade passível de discussão é a permissão ou não da passagem dos operários e materiais por dentro dos apartamentos durante a execução dos serviços, para acesso aos balancins. Esse problema pode ser contornado com a utilização de balancins de acionamento elétrico, mais rápidos, entretanto com custo mais elevado. Os balancins do tipo cabo passante também permitem certa agilidade nesse transporte, apresentando-se como uma alternativa de custo mais baixo.

Como ação preventiva, antes do início da obra a fiscalização pode realizar uma vistoria das condições de conservação das áreas sociais, principalmente cobertura e locais descobertos do pavimento térreo ou mezanino.

Na cobertura, a colocação de elemento para apoio dos balancins, cordas de segurança e telas de proteção, entre outros, pode danificar a sua impermeabilização original ou as telhas, calhas e algerozes existentes. Vale salientar, ainda, que a cobertura é um local muito utilizado na obra pelos seus operários, devido à necessidade constante de alterações na posição dos referidos elementos de apoio.

Nas edificações mais modernas, para as quais foi prevista a realização periódica de atividades de manutenção na fachada, os danos são menores. Entretanto, considerando que a cultura de manutenção é ainda incipiente no país, a maioria das edificações onde são realizadas essas atividades não foram devidamente projetadas com tal concepção, dificultando a sua implementação.

Já nas áreas sociais do térreo, e eventualmente também em edificações vizinhas (principalmente telhados, em casas baixas), por maiores que sejam os cuidados é sempre possível a ocorrência de algum tipo de sinistro em decorrência das atividades desenvolvidas na obra.

Assim, nessas três situações (cobertura, área térrea social e vizinhança) pode ser realizada vistoria para avaliação e registro das condições antes do início das atividades. $O$ 
registro pode ser feito por meio da apresentação de fotografias com comprovação da data, conhecimento e consentimento dos interessados, a saber: condomínio, empresa executante e vizinhos. Nesse documento são definidas, ainda, responsabilidades (ônus) decorrentes da necessidade de eventuais atividades de manutenção.

No tocante à ocorrência de distúrbios diversos relacionados com o comportamento e higiene dos operários da obra, na própria carta-convite enviada às empresas concorrentes, parte integrante do contrato, são estabelecidas as regras claras exigidas para uma boa ordem, inclusive sanções cabíveis. Com isso, qualquer tipo de distúrbio previsto no contrato causado na obra por operários pode ser passível de punição, conforme critério de avaliação da fiscalização.

No caso dos balancins, um cuidado importante relacionado com a segurança é não permitir que os mesmos permaneçam pendurados e amarrados em algum pavimento ao longo da fachada, a menos que isso ocorra apenas entre dias consecutivos de serviço. Com isso, evita-se que durante um final de semana, por exemplo, a ocorrência de uma chuva ou ventilação internas provoque a ruptura da sua amarração, levando risco a usuários e transeuntes.

Por fim, outro aspecto que pode ser discutido nesse tipo de obra é o destino dado ao entulho produzido, problema que vem sendo tratado com rigor cada vez maior por parte dos órgãos competentes, principalmente no tocante ao local de despejo. 


\section{ESTUDO DE VALIDAÇÃO - CONCEITOS E MÉTODO}

O objetivo dessa etapa do trabalho é apresentar uma discussão a respeito de como será conduzida a validação do método proposto (apresentado na Tabela 8) e discutido na abordagem teórica inicial, a partir da apresentação de conceitos a respeito do tema. No Capítulo 6 será realizada discussão dos resultados obtidos para, ao final, ser apresentado o método final validado.

Conforme já anteriormente descrito na Introdução (Capítulo 1), existem diferentes maneiras de avaliar criticamente a proposição de um método, com o objetivo de torná-lo válido cientificamente. Algumas alternativas de avaliação são os estudos de caso, as consultas ordenadas a profissionais especialistas (validação interna de conteúdo), ou a aplicação das proposições, já validadas em seu conteúdo, em um caso prático (validação externa).

Para cada alternativa existem opiniões diversas a respeito das suas características. Conforme destacado por Laville e Dione (1999), em algumas áreas os estudos de caso são criticados, pois resultam em conclusões de difícil generalização, não se podendo garantir a sua aplicação em outros casos. Por outro lado, possibilitam um aprofundamento do assunto, adaptando o estudo aos seus instrumentos de pesquisa, já que não estão atrelados a restrições metodológicas.

Quanto à validação interna, Richardson (1999) enfatiza a importância de se garantir que o instrumento utilizado na pesquisa (questionário, proposta ou método) seja capaz de avaliar o que se deseja, mesmo que a sua estruturação seja comprovadamente confiável. Preocupação similar é discutida por Costa (2001), que sugere a avaliação da eficiência de um questionário, por exemplo, por meio do envio prévio a outros pesquisadores, a fim de transformar uma lista de perguntas em um instrumento efetivo de pesquisa.

Em seu trabalho de doutorado, Barros (1996) propôs método para implantação de tecnologia racionalizada em que a validação se deu, inicialmente, a partir do acompanhamento experimental dessa implantação em duas empresas construtoras. Em seguida, foi realizada pesquisa junto a empresas que atuavam num processo construtivo tradicional e, por fim, verificou-se a adequação do método em outras 10 empresas. Nesse 
caso foi efetuada uma comprovação final do trabalho a partir da experiência obtida na aplicação do método com os próprios agentes envolvidos.

Campante (2001) também apresentou validação da sua proposta metodológica, nesse caso referente ao diagnóstico, recuperação e prevenção de problemas em revestimentos de fachada. A proposta apresentada pelo autor foi validada a partir de uma pesquisa de campo efetuada por meio de 4 estudos de caso.

Outros exemplos de validação na cadeia produtiva da construção podem ser citados, como os trabalhos de Hatush e Skitmore (1997) e Gao et al. (2002). O primeiro discute a avaliação de 20 critérios propostos de seleção para o sucesso de um projeto a partir de uma validação realizada com consultores especialistas, precedida de uma pesquisa realizada junto a participantes escolhidos em diferentes organizações. No segundo caso foi feita análise parecida para avaliação dos fatores de sucesso de contribuem para o desenvolvimento de projetos de obras de grande e pequeno porte. Nesse caso foi efetuada pesquisa com gestores de empresas recrutadas para o estudo, seguida da validação por meio de questionários.

Por fim, Santos et al. (2005) também apresentam artigo onde são discutidas duas dissertações de mestrado no ambiente construído em que foi utilizada a técnica de validação interna de conteúdo a partir do método Delphi. As pesquisas tratavam das diretrizes para o planejamento de canteiros de obras de pavimentação em concreto e da avaliação da competência de gerentes de empresas construtoras (defendidas na UFPR por Carlos Roberto Giublin e Lisiane Vidotto, respectivamente, em 2002 e 2003).

No presente estudo, foi realizada a validação interna de conteúdo a partir da aplicação do método Delphi, complementada por uma avaliação da aplicabilidade das propostas em um caso de obra de manutenção em fachada no qual as propostas foram implementadas de forma orientada, realizada simultaneamente à validação interna.

\subsection{Discussões sobre o método Delphi}

A validação interna de uma proposta tem como conceito básico a discussão junto a especialistas a respeito da sua adequação e aplicabilidade. O conteúdo dessa proposta deve contemplar as ações tomadas com o intuito de se obter adequado desempenho técnico e 
operacional das atividades realizadas (de uma obra, por exemplo), com base na previsão de comportamento esperado ao longo do seu andamento.

Nesses termos, uma técnica eficiente de apoio para o planejamento é o Método Delphi, em cuja formulação se busca um consenso entre especialistas a respeito das projeções de futuro.

Como abordam Wright e Giovinazzo (2000), "o método Delphi, em linhas gerais, consiste numa consulta a um grupo de especialistas a respeito de eventos futuros através de um questionário, que é repassado continuadas vezes até que seja obtida uma convergência de respostas". Parte-se do pressuposto de que o julgamento coletivo, caso bem organizado, é melhor do que a opinião de um só indivíduo.

Essa técnica, entendida também como uma prospecção de tendências com o objetivo de sustentar o planejamento de longo prazo, é oriunda dos ramos de administração de empresas e economia e data da década de 60, e teve o seu nome, segundo Massaud (2007) inspirado no oráculo de Delfos, na Grécia, dedicado a Apolo.

A correta aplicação da técnica depende da observância de três condicionantes básicos (KAYO e SECURATO, 1997; MASSAUD, 2007; WRIGHT e GIOVINAZZO, 2000):

- Anonimato das respostas, o que elimina a influência do nível acadêmico ou profissional dos envolvidos, assim como a supressão de opiniões minoritárias;

- Troca de informações entre os respondentes e o coordenador da pesquisa, já que cada participante deve conhecer o que se está pesquisando e saber a representação estatística da sua visão perante o grupo;

- Possibilidade de revisão das respostas a partir das posições apresentadas pelos demais componentes do grupo.

O trabalho se inicia a partir da elaboração de questões diversas relativas ao tema de pesquisa, formuladas a partir de uma adequada revisão bibliográfica. Recomenda-se que as perguntas sejam claras e objetivas, cuidando-se para que não ocorra nenhum tipo de indução das respostas pelo coordenador da pesquisa (SANTOS et al., 2005).

Em seguida é necessário se definir os critérios de inclusão dos especialistas participantes da pesquisa, o que é dependente do tema e abrangência do estudo. Em geral 
são escolhidos profissionais com reconhecido conhecimento específico do assunto, seja no meio acadêmico ou prático. A quantidade mínima de respondentes é também relativa, sendo admitido por Giovinazzo (2001), por exemplo, um número de 15 a 30 como suficiente para obtenção de informações relevantes.

As respostas obtidas são tabuladas e tratadas com estatística simples e, assim, são devolvidas aos participantes para que os mesmos possam reavaliar suas respostas à luz das observações apresentadas pelos demais respondentes na rodada anterior. Como bem destaca Kayo e Securato (1997), a depender do caso o tratamento estatístico dado nesse "feedback" pode até ser por meio de distribuição de freqüência absoluta, desde que seja assegurada a passagem segura e confiável de informações claras aos participantes.

Com base nos dados coletados as discussões devem ser aprofundadas, de modo que é importante que não apenas a análise estatística, mas também os comentários apresentados nas respostas sejam encaminhados para apreciação de todos. Esse procedimento é essencial, uma vez que, como destacam Kayo e Securato (1997), existe uma dificuldade natural dos pesquisadores em alterar suas posições, decorrente da autosuficiência, da relutância em admitir incapacidade, entre outros aspectos sociológicos. Essas etapas são repetidas até que a divergência de opiniões entre os especialistas se tenha reduzido a um nível satisfatório.

A quantidade de etapas (ou rodadas) necessária vai depender de cada caso, sendo recomendado um número máximo de quatro, a fim de evitar dispersão dos participantes (KAYO e SECURATO, 1997). Nos casos em que a pesquisa é realizada utilizando a internet como ferramenta, Giovinazzo (2001) recomenda que esse número não seja superior a duas rodadas, sob pena de se tornar desinteressante para os especialistas.

Como destacam Santos et al. (2005), a comunicação regular entre os participantes e o coordenador da pesquisa é essencial durante o trabalho, tornando-o objetivo e com menos ruídos (feedback controlado).

Cardoso et al. (2005) apresentaram aplicação do método Delphi para a cadeia produtiva da construção habitacional, indicando como vantagem principal da técnica a possibilidade de obtenção de um pensamento claro e atualizado sobre a perspectiva de futuro do setor, a partir da reflexão individual e coletiva de um conjunto de especialistas. 
Com isso, conforme destaca Massaud (2007), obtém-se respostas com maior liberdade por parte dos participantes, sem pressões de opiniões externas, a um custo bastante baixo.

As desvantagens do método destacadas no trabalho de Cardoso et al. (2005) foram a necessidade de comprovação da eficiência do questionário, o que, segundo os autores, pode ser resolvido a partir de uma validação prévia com outros especialistas, o longo prazo para a sua realização, de seis a doze meses, e a dificuldade de obtenção da colaboração de especialistas, refletido nos altos índices de abstenção e desistência ao longo do trabalho.

Kayo e Securato (1997) destacam também como problemas inerentes ao método a dificuldade de avaliação do grau de especialização dos respondentes, e a natural imposição do ponto de vista do pesquisador durante o trabalho, em face de uma eventual exploração deficiente dos pontos de discordância.

Algumas das desvantagens apontadas nessa técnica podem ser atenuadas a partir da obtenção das respostas utilizando a internet como ferramenta. Giovinazzo (2001) aponta como vantagem nesse caso a maior agilidade para obtenção dos dados e trocas de informações, além de ser uma mídia flexível e de fácil acesso para a maioria dos respondentes, porém recomenda a disponibilidade de uma equipe de informática para suporte e também a formulação de perguntas objetivas. A referida pesquisadora afirma que a internet tem se mostrado bastante eficiente para o desenvolvimento do método.

O Método Delphi, portanto, mostra-se útil para as atividades de planejamento, uma vez que permite prospectar o comportamento futuro de um determinado processo produtivo, em função das ações tomadas no presente.

Importante destacar que, como aborda Massaud (2007), a fim de se obter o objetivo da pesquisa são admitidas variações em algumas das características do método, desde que garantidas as condições básicas de anonimato, feedback dos dados aos participantes, e possibilidade de alterações nas respostas. Nos dois trabalhos realizados no âmbito ambiente construído e apresentados por Santos et al. (2005), foram efetuadas adaptações às considerações apresentadas, com resultados julgados satisfatórios sob o ponto de vista metodológico.

Por fim, como destacam Wright e Giovinazzo (2000), o método se caracteriza não apenas por um instrumento de previsão, mas pode servir como uma técnica de apoio para a 
tomada de decisão e definição de estratégias e ações. Ou seja, às vezes pode não se buscar o consenso, mas a geração mesmo de pontos de vista conflitantes. 


\subsection{Aplicação do método na Tese}

Para que se possa ter uma avaliação mais consolidada dos elementos propostos no trabalho, é apresentada nesse item a sua validação interna realizada com especialistas selecionados mediante critérios de escolha pré definidos e procedimento de análise utilizando o Método Delphi.

Os itens apresentados na pesquisa foram divididos em grupos, de modo que a pesquisa pudesse ser efetuada de forma eficiente com os especialistas, o que facilitou a obtenção e análise dos dados. Na Figura 8 é apresentado um fluxograma esquemático indicando as atividades desenvolvidas durante a realização da pesquisa, desde o embasamento metodológico até a conclusão do trabalho.

Como se pode observar, a pesquisa foi iniciada com a discussão da proposta metodológica, a partir da qual foi elaborado o questionário inicial posteriormente utilizado. As perguntas foram elaboradas de modo que os participantes pudessem responder indicando suas opiniões por meio de escalas, de I a IV, conforme se segue: I: Irrelevante; II: Pouco relevante; III: Muito relevante; IV: Imprescindível. Para facilitar o entendimento as questões foram agrupadas por tópicos representativos das várias etapas de execução dos serviços propostos.

Conforme anteriormente relatado, um ponto essencial de discussão nesse tipo de pesquisa é sobre a maneira mais indicada para se coletar as informações junto aos participantes, que pode ser por meio de correspondências, fax, e-mails, entre outros. Uma vez que o objetivo da pesquisa é promover a discussão das opiniões de profissionais diversos especialistas, a forma mais racional encontrada nesse caso foi utilizando a internet, ferramenta simples e de fácil acesso aos participantes.

A partir dessa mídia, a coleta das informações pode ser efetuada ou com um questionário enviado a todos os participantes por meio dos seus endereços eletrônicos que, depois de respondido, é novamente encaminhado para avaliação, ou a partir de um site onde os usuários podem pesquisar diversas informações relativas ao tema durante a elaboração das suas respostas, com acesso restrito por uma senha individual. 


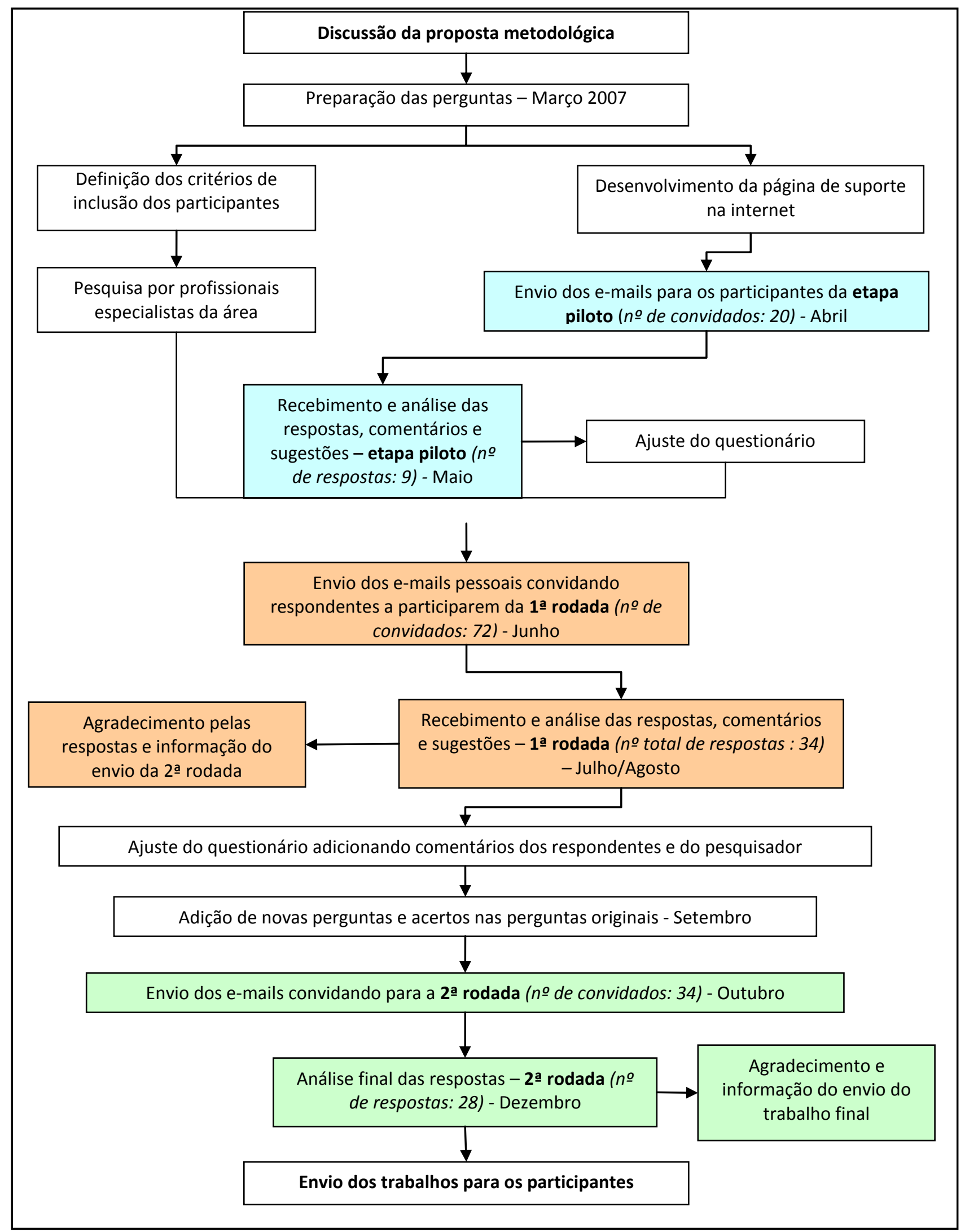

Figura 8 - Fluxograma das atividades realizadas para a validação interna. 
Nesse caso optou-se pela elaboração da página de acesso na internet, especialmente em face da maior facilidade de controle de eventuais alterações, e também para proporcionar um ambiente mais agradável para o respondente. Outro aspecto importante é que o participante pode ir evoluindo por grupo de perguntas, e as respostas já são diretamente gravadas e enviadas.

Com isso, o coordenador da pesquisa pode saber, por exemplo, se a pessoa demonstrou interesse e começou a responder, mas não teve tempo de concluir tudo. Nesses casos, pode-se mandar uma mensagem perguntando se o questionário ainda será concluído e, caso contrário, as perguntas já respondidas podem ser levadas em conta.

A opção pela página também permite disponibilizar algumas informações importantes sobre os pesquisadores (doutorando e orientador), o que favorece no sentido de proporcionar maior segurança aos participantes. Esse detalhe se revela importante por conta da insegurança de alguns usuários da internet para passar informações de cunho pessoal utilizando essa ferramenta.

Assim, foi contratada equipe de desenvolvimento de software composta por alunos de graduação do curso de Ciências da Computação da Universidade Federal de Pernambuco, que elaboraram a página e a administraram durante o desenvolvimento da pesquisa, no sítio $<$ http://pesquisadelphi.eng.br>.

Concluída a preparação foi dado início à primeira fase da pesquisa, a etapa piloto, melhor discutida no item 5.2.1, da qual participaram não apenas especialistas nas áreas de interesse da pesquisa, mas também profissionais de informática e administração, com conhecimento relativo à qualidade da diagramação do texto e detalhes referentes às perguntas, importantes para a continuidade do estudo.

Em paralelo à etapa piloto foi efetuada pesquisa para identificação de profissionais especialistas na área e discussão dos critérios para inclusão dos participantes no estudo. A grande quantidade de assuntos abordados no estudo, associado à sua marcante interdisciplinaridade, impossibilitou que fossem encontrados profissionais cujas especialidades conseguissem abranger todos os temas.

Por isso, foram pesquisados profissionais das áreas de tecnologia de materiais e de processos construtivos, que poderiam opinar de maneira mais embasada sobre os assuntos 
em análise. As fontes principais de busca utilizadas foram os centros de pesquisa de universidades diversas pelo país, bem como autores de artigos técnicos específicos publicados em congressos nacionais.

As circunstâncias citadas conduziram a critérios de inclusão que assegurassem a participação apenas de profissionais especialistas em alguma das áreas de estudo do trabalho, ou mesmo atuantes no mercado de obras de manutenção. Não foi estipulado elevado rigor acadêmico a fim de não restringir de forma excessiva a amostra disponível para o estudo. Com isso, todos participantes da pesquisa atendem a, pelo menos, dois dos seguintes critérios:

- Vínculo a centros de ensino e pesquisa;

- Experiência no ramo de atividade de obras de manutenção em fachadas há pelo menos 5 anos;

- Publicação, pelo menos, de 3 artigos técnicos em congressos, simpósio, jornais ou revistas técnicas especializadas nos últimos 10 anos.

\subsubsection{Etapa 1 - Piloto}

A etapa piloto tem o objetivo de avaliar a eficiência das atividades que serão desenvolvidas na pesquisa, antes da sua implantação junto aos respondentes. As perguntas do questionário foram todas elaboradas com base nas propostas de gestão discutidas ao longo do Capítulo 4, e as respostas eram dadas a partir do grau de importância admitido pelos especialistas para cada um dos itens discutidos, conforme se segue: I: Irrelevante; II: Pouco relevante; III: Muito relevante; IV: Imprescindível; SO: sem opinião.

A ordem e a segmentação das perguntas apresentadas no questionário atenderam à seqüência adotada no presente texto, e que representam a ordem natural de execução dos serviços. Desta forma, o questionário foi composto pelas seguintes perguntas: 
QUESTIONAMENTOS - ASPECTOS FUNDAMENTAIS DA PROPOSTA METODOLÓGICA

Indique a sua opinião a respeito do grau de importância das seguintes atividades macro para uma adequada gestão de obras de manutenção de fachada em edificações em uso:

1. Preparação do diagnóstico das necessidades da obra.

2. Discussão dos prazos e custos para a execução dos serviços.

3. Definição dos critérios e regras para seleção das empresas concorrentes.

4. Discussão dos aspectos técnicos, operacionais e financeiros envolvidos na contratação.

5. Acompanhamento / fiscalização dos serviços.

\section{QUESTIONAMENTOS - DIAGNÓSTICO}

6. Indique o grau de importância de se utilizar uma metodologia padrão para a elaboração de um correto diagnóstico das necessidades.

\section{Quanto à INVESTIGAÇÃO DAS NECESSIDADES da obra, analisar os seguintes questionamentos:}

7. Indique o grau de importância da coleta das seguintes informações para uma adequada investigação do caso: idade do prédio, posicionamento das fachadas, materiais e procedimentos utilizados na época da construção, solução estrutural.

8. Indique o grau de importância da coleta das seguintes informações para um adequado diagnóstico das necessidades do caso: projeção esquemática da fachada, contemplando cotas, estado de conservação, evolução (tempo e local de ocorrência) de eventuais problemas, atividades de manutenção já realizadas.

9. Indique o grau de importância da realização de pesquisa junto aos usuários para identificação de informações eventualmente não verificadas na coleta inicial.

\section{Quanto aos ENSAIOS necessários, analisar os seguintes questionamentos:}

10. Indique o grau de importância da realização de ensaios de resistência de aderência à tração direta para os revestimentos aderidos.

10.1 Indique o grau de importância da realização de ensaios de resistência de aderência 
à tração direta para os revestimentos aderidos, caso a edificação apresente algum problema visual de desplacamento, indicando a necessidade de uma manutenção CORRETIVA $(*)$.

10.2. Indique o grau de importância da realização de ensaios de resistência de aderência à tração direta para os revestimentos aderidos, caso a edificação não apresente problema visual de desplacamento, indicando eventual necessidade de manutenção apenas PREVENTIVA $\left({ }^{*}\right)$.

11. Indique a sua opinião sobre a execução de 1 pano de ensaio (composto por 6 pontos de arrancamento) a cada $1.000 \mathrm{~m}^{2}$ de fachada, em locais espalhados ao longo dos pavimentos (1 - mto pouco, 2 - pouco, 3 - satisfatório, 4 - excessivo).

11.1 A definição da quantidade de pontos necessários para a avaliação das necessidades do caso é subjetiva, a depender da situação em que a edificação se encontra (2 - não concordo; 3 - concordo; 5 - sem opinião) $\left(^{*}\right)$.

12. Indique o grau de importância da realização de ensaios de percussão como auxiliar para o diagnóstico e extensão das necessidades da obra.

13. Indique o nível de segurança e confiabilidade, com os meios técnicos disponíveis atualmente, de se balizar nos ensaios de aderência e percussão para a avaliação das necessidades da obra.

\section{Quanto à DISCUSSÃO DE ALTERNATIVAS, analisar os seguintes questionamentos:}

14. Indique o grau de importância da apresentação de soluções técnicas para a execução dos serviços, apontando vantagens e desvantagens, com base no prognóstico da evolução da conservação da fachada e dos seus componentes.

15. Indique o grau de importância da discussão dos seguintes aspectos para cada solução: estimativa de custos e prazos, transtornos envolvidos, âmbito da garantia ofertada pelos construtores, riscos envolvidos, necessidade futura de manutenção, valorização comercial.

\section{QUESTIONAMENTOS - PRAZOS E CUSTOS}

Quanto aos PRAZOS da obra, analisar os seguintes questionamentos: 
16. Indique o grau de importância de se discutir com o condomínio os aspectos relacionados com o prazo de execução dos serviços, levando-se em conta aspectos como: riscos de um eventual adiamento, transtornos, impactos financeiros, influência das condições ambientais.

\section{Quanto aos CUSTOS da obra, analisar os seguintes questionamentos:}

17. Indique o grau de importância da existência de um modelo padrão de planilha para a elaboração do orçamento básico das obras, passível de adaptação para cada caso.

18. Indique o grau de importância da realização do levantamento dos quantitativos no local, e sua apresentação ao condomínio por trechos separados da fachada (memória de cálculo), a fim de facilitar as atividades de controle.

19. Indique o grau de confiabilidade da cotação de preços de referência em 3 fontes diferentes do mercado (empresas, armazéns etc.) para a obtenção do custo final.

\section{QUESTIONAMENTOS - SELEÇÃO DAS EMPRESAS}

\section{Quanto aos procedimentos para seleção das empresas concorrentes, analisar os seguintes questionamentos:}

20. Indique o grau de importância da disponibilização para as empresas concorrentes de um documento formal (Edital) contemplando especificações, projetos, regras para a contratação, planilha orçamentária de referência e critério de seleção.

21. Indique o grau de importância das seguintes informações a respeito das empresas concorrentes: comprovação de serviços similares, certidão negativa de débitos e capital social (compatível com o porte da obra).

22. Indique o grau de importância de encaminhar às empresas concorrentes uma planilha orçamentária, sem os preços de referência, a ser preenchida por todos.

23. Indique o grau de importância da seleção das empresas ocorrer não apenas pelo menor preço, mas também pela sua qualificação.

\section{QUESTIONAMENTOS - CONTRATAÇÃO}




\section{seguintes questionamentos:}

24. Indique o grau de importância da explicitação em contrato dos seguintes aspectos econômicos: preços, reajustes, pagamentos, sanções e multas.

25. Indique o grau de importância de se definir em contrato que os preços e as quantidades estipulados em contrato sejam irreajustáveis.

25.1 Indique a importância de se definir em contrato que as quantidades estipuladas sejam irreajustáveis, a menos que ocorra alguma alteração de projeto (*)

25.2 Indique a importância de se definir em contrato que os preços apresentados no orçamento contratado sejam irreajustáveis, a menos que ocorra alguma alteração profunda na conjuntura econômica (*).

26. Indique o grau de importância de se discutir com o condomínio as vantagens e desvantagens envolvidas em cada modalidade prevista para o pagamento.

27. Indique o grau de importância de se proceder a uma retenção dos valores pagos à empresa executante para quitação apenas no final dos serviços.

\section{Quanto aos aspectos TÉCNICOS previstos em contrato, analisar os seguintes questionamentos:}

28. Indique o grau de importância de se estabelecer quantidades mínimas de equipamentos e pessoal para o início dos serviços.

29. Indique o grau de importância da presença sistemática de um representante técnico da empresa executante em tempo integral na obra.

30. Indique o grau de importância de se estipular bônus ou prejuízos no caso de descumprimento dos prazos pela empresa executante.

31. Indique o grau de importância da entrega de um documento final, do tipo "As Built", formalizando a conclusão e entrega da obra.

32. Indique o grau de importância da entrega pela empresa executante de um manual de operação, uso e manutenção após a conclusão dos serviços.

Quanto aos aspectos OPERACIONAIS previstos em contrato, analisar os seguintes 


\section{questionamentos:}

33. Indique o grau de importância da retenção na fonte do pagamento das obrigações fiscais e trabalhistas nas medições efetuadas pela construtora.

34. Indique o grau de importância da conferência, registro e documentação da quitação dos referidos pagamentos ao longo da obra.

35. Indique o grau de importância da apresentação da Certidão Negativa de Débitos (CND) antes da liberação do primeiro pagamento.

36. Indique o grau de importância da investigação prévia (inclusive documentação e registro) das áreas diversas da edificação e da vizinhança quanto à conservação.

\section{QUESTIONAMENTOS - ACOMPANHAMENTO}

\section{Quanto aos aspectos TÉCNICOS envolvidos durante o acompanhamento da obra, analisar os seguintes questionamentos:}

37. Indique o grau de importância da definição dos tipos de ensaio, amostragem e entidades para realização de ensaios diversos.

38. Indique a sua opinião sobre a realização de ensaios de aderência em 2 panos, cada qual composto por 3 pontos de arrancamento, em cada balancim, espalhados ao longo dos pavimentos (1 - mto pouco, 2 - pouco, 3 - satisfatório, 4 - excessivo).

\section{Quanto aos aspectos OPERACIONAIS envolvidos durante o acompanhamento da obra, analisar os seguintes questionamentos:}

39. Indique o grau de importância e eficiência do acompanhamento dos prazos de execução da obra por meio da comparação entre os cronogramas físico financeiro real e previsto.

40. Indique o grau de importância e eficiência de se condicionar o primeiro pagamento à apresentação, pela construtora, do Cadastro Específico do INSS (CEI) da obra, que envolve a ART, comprovação do CNPJ, projeto e alvará de licença para construção aprovado pela prefeitura.

41. Indique o grau de importância e eficiência de se condicionar os diversos pagamentos à apresentação, pela construtora, das guias de quitação de recolhimento de FGTS e INSS. 
42. Indique o grau de importância do controle da correta execução dos elementos de segurança (bandejas, aparatos, sinalização, telas etc.)

43. Indique o grau de importância da exigência do uso de EPI's e elementos de identificação por parte dos operários.

44. Indique o grau de importância da exigência da exigência de vistorias regulares semestrais da Delegacia Regional do Trabalho (DRT).

\section{QUESTIONAMENTOS - QUESTÕES FINAIS}

45. Indique a importância de uma consultoria independente do condomínio e da construtora para a gestão das atividades de gerenciamento.

$(*)$ - questionamentos acrescentados apenas na segunda rodada de perguntas.

Ao total, foram cadastradas 20 pessoas para participação nessa etapa piloto, entre profissionais especialistas e não especialistas, uma vez que havia a intenção de verificar também a eficiência do questionário quanto à diagramação, clareza das perguntas, tempo necessário para as respostas, entre outros.

As mensagens eletrônicas foram enviadas na primeira semana de abril de 2007 , com solicitação do preenchimento do questionário num prazo de 7 dias. Interessante notar que, conforme percebido também na primeira rodada, aqueles que não apresentavam qualquer tipo de resposta logo nos primeiros dias após o envio do e-mail, em geral, acabaram não participando da pesquisa, indicando ser acertada a decisão de estipular prazos curtos para as respostas.

Cabe também destacar que, em vários casos, antes do envio da mensagem foi efetuado contato telefônico com os participantes esclarecendo o objetivo do trabalho e o funcionamento da pesquisa, especialmente para aqueles que não atuam na área, a fim de estimular a avaliação de todos.

Após a conclusão do prazo, $65 \%$ das pessoas (13, dentre 20) que receberam a solicitação responderam o questionário. Dentre os que responderam, quatro não cumpriam as exigências definidas nos critérios de inclusão, enquanto os demais acabaram também fazendo parte também das demais fases do trabalho. 
As principais recomendações indicadas pelos participantes nessa etapa se referiram à diagramação da página, a facilidades na interface com o usuário (a inclusão imediata, na tela, dos comentários efetuados, aparecimento de tela informativa ao usuário que as respostas não foram todas concluídas, para os casos em que o mesmo resolva responder parcialmente, colocação da opção "sem opinião") e, em poucos casos, a ajustes nos questionamentos.

Ao todo, o tempo necessário para execução dessa etapa foi de três meses corridos, sendo 45 dias destinados à elaboração do questionário e preparação do site, e mais 45 dias decorridos desde o envio das mensagens eletrônicas para os participantes até o recebimento e avaliação das respostas enviadas.

\subsubsection{Etapa 2 - 1a rodada de perguntas}

Após os ajustes indicados na etapa piloto, a primeira rodada de perguntas foi encaminhada aos potenciais participantes da pesquisa no intuito de se obter o maior numero possível de opiniões. Trata-se do primeiro contato de todos com a idéia da pesquisa, razão pela qual se recomenda que os objetivos e a forma de participação estejam claramente apresentados e definidos.

Para isso, na primeira página do site foi apresentada uma breve explicação sobre o método de pesquisa e sobre a Tese, conforme observado no Anexo B. Além disso, foram ainda disponibilizadas informações sobre os pesquisadores (orientando e orientador), com link direto para os respectivos currículos Lattes, e sobre o centro de pesquisa da Escola Politécnica da Universidade de São Paulo.

Conforme anteriormente comentado, foi efetuado convite formal aos respondentes por e-mail, sempre com mensagens individualizadas para cada um, com o objetivo de estimular a participação. Essa prática permite uma aproximação maior junto aos participantes, que se podem sentir resguardados quanto à importância e mesmo quanto à segurança dos dados enviados. Para o caso de pessoas desconhecidas do autor do estudo, ao longo do texto da mensagem aparecia alguma explicação que pudesse justificar o convite, especialmente a citação de artigos publicados em eventos técnicos com temas afins daqueles discutidos na pesquisa. 
Em virtude da grande quantidade de mensagens eletrônicas recebidas diariamente, com os mais diversos conteúdos, é prática comum das pessoas não ler mensagens enviadas a grupos. Para atenuar o problema, o campo assunto indicado na mensagem sempre indicava a expressão "Pesquisa Delphi", seguida pelo nome do destinatário.

Para a escolha dos potenciais participantes da pesquisa a procura pode ser segmentada em três grandes grupos: pessoas do círculo de conhecimento do autor e atuantes na área de estudo, em geral pós-graduandos contemporâneos; professores de reconhecido conhecimento do tema; e autores de artigos técnicos correlatos publicados em eventos técnicos recentes do setor. Além desses, ao longo dessa etapa foram adicionados outros potenciais respondentes indicados pelos próprios participantes.

Ao todo foram convidadas a participar da pesquisa 72 pessoas (já incluídas as 9 oriundas da etapa piloto), atividade iniciada na primeira semana de junho de 2007. À medida que as respostas eram enviadas, cada participante recebia uma mensagem eletrônica individual de confirmação de envio e agradecimento, informando também que em breve seria solicitada nova rodada de perguntas. Até o final de julho foram coletadas 34 respostas, que corresponde a $47 \%$ dos enviados, além daqueles que responderam justificando a impossibilidade de participar.

O tempo total para coleta das respostas junto aos especialistas durou cerca de 2 meses, sendo ainda necessários mais 2 meses para a análise das respostas, tabulação, preparação e envio da segunda rodada de perguntas.

\subsubsection{Etapa $3-2^{a}$ rodada de perguntas}

As respostas e os comentários enviados na primeira rodada de perguntas foram tabulados em uma planilha eletrônica para permitir uma melhor avaliação tanto dos respondentes como do próprio coordenador da pesquisa.

Para a segunda rodada em cada pergunta foram apresentados os percentuais das respostas encaminhadas pelo grupo em cada alternativa disponível, bem como aquela escolhida pelo próprio especialista (ver Figura 9). Os comentários apresentados pelos participantes em cada questão foram também disponibilizados, sem identificação dos 
autores, além de informações adicionadas pelo pesquisador e julgadas importantes para esclarecimento de dúvidas surgidas.

\begin{tabular}{|c|c|c|c|c|c|c|}
\hline \multirow{2}{*}{ QUESTIONAMENTO } & NR & I & II & III & IV & so \\
\hline & A & \multicolumn{4}{|c|}{ B } & C \\
\hline \multicolumn{7}{|c|}{$\begin{array}{l}\text { Textos apresentados na cor preta - Comentários selecionados apresentados pelos respondente } \\
\text { Textos apresentados na cor vermelha - Comentários apresentados pelo pesquisador (Angelo). }\end{array}$} \\
\hline \multicolumn{7}{|c|}{$\begin{array}{l}\text { A - Quantidade percentual de participantes que não responderam à pergunta, a partir do total de } \\
\text { respondentes. } \\
\text { B - Quantidades percentuais de respostas, calculados apenas dentre aqueles que apresentaram algum tipo de } \\
\text { opinião (I, II, III e IV). } \\
\text { C - Quantidade percentual de participantes que optaram por responder sem opinião, a partir do total de } \\
\text { respondentes. } \\
\text { NR - NÃO RESPONDEU SO - SEM OPINIÃO }\end{array}$} \\
\hline
\end{tabular}

Figura 9 - Imagem extraída do site explicando as informações apresentadas aos especialistas na $2^{a}$ rodada.

Às questões relativas aos ensaios ( $n$ ㅇ 10 e 11) realizadas durante a investigação das necessidades do prédio, por exemplo, foram adicionados novos questionamento com o objetivo de aprofundar as informações inicialmente colhidas. As novas respostas enviadas reforçaram os dados originais, facilitando o entendimento das opiniões.

Também foram adicionadas indagações na questão no 25 , que trata da explicitação em contrato da impossibilidade de reajuste dos preços e quantidades durante a obra. Novamente essa ação permitiu um maior aprofundamento das opiniões dos especialistas, confirmando o que se havia informado na rodada inicial.

Em todas as questões apresentadas se pôde perceber uma tendência de confirmação das respostas encaminhadas na primeira rodada em todos os $\operatorname{casos}^{38}$, avaliados a partir da repetição ou aumento dos valores máximos admitidos para as alternativas disponíveis. Por essa razão se julgou a suficiente a realização de apenas duas rodadas de perguntas.

A forma de tratamento com os respondentes foi semelhante àquela adotada na primeira rodada, a partir do envio de mensagens eletrônicas individuais a cada um dos que participaram da etapa inicial convidando para continuidade da pesquisa.

\footnotetext{
${ }^{38}$ Valores percentuais com diferenças de $\pm 2 \%$ foram consideradas repetições.
} 
Apesar de já ter sido anteriormente explicado nas mensagens eletrônicas e na própria página da rede, foi novamente explicado aos participantes a razão pela qual havia a necessidade deles responderem pela segunda vez ao questionário, atentando para o fato de que eles poderiam reavaliar as suas considerações a partir das respostas e comentários do grupo.

Nessa segunda rodada, a partir da entrada dos especialistas na página principal do site, havia a apresentação gráfica dos agentes envolvidos na atividade de gestão e um fluxograma das ações propostas no estudo, com o objetivo de orientá-los melhor a respeito das discussões da tese e da sua estrutura.

Na primeira semana de outubro foram enviados os convites por meio de mensagens eletrônicas para que os 34 respondentes da primeira rodada pudessem participar da segunda etapa. Até o final de novembro foram encaminhadas 28 respostas, que representa $82 \%$ de participação.

Interessante destacar que, ao contrário das demais etapas, quando a maioria dos participantes enviava as suas respostas logo na primeira semana após o convite, nesse caso as respostas demoraram um pouco mais para serem encaminhadas.

As razões para esse comportamento podem ser explicadas pela necessidade de uma melhor investigação das respostas após a inclusão dos comentários e dos percentuais, e também pela real intenção de participar da fase final da pesquisa, mesmo que não fosse logo nas primeiras semanas. A abstenção de apenas 6 dos 34 participantes da etapa inicial indica que a tendência é que a maioria daqueles que se prestaram a analisar o questionário na primeira etapa também queiram fazê-lo na segunda.

Concluída a coleta dos dados enviados foi possível elaborar um perfil dos participantes da pesquisa, conforme representado na 
Tabela 13. 
Tabela 13 - Perfil dos participantes da validação interna de conteúdo.

\begin{tabular}{|c|c|c|c|}
\hline \multirow{2}{*}{ PERFIL } & \multicolumn{2}{|c|}{ 1a RODADA } & \multirow{2}{*}{$\begin{array}{l}\text { 2a RODADA } \\
\text { Respondentes }\end{array}$} \\
\hline & Consultados & Respondentes & \\
\hline & 72 & 34 & 28 \\
\hline Professores & 45 & 17 & 13 \\
\hline Pós graduandos & 10 & 6 & 5 \\
\hline Outros & 17 & 11 & 10 \\
\hline Doutores & 37 & 12 & 9 \\
\hline Mestres & 33 & 20 & 17 \\
\hline Especialistas & 2 & 2 & 2 \\
\hline Região - Sudeste & 38 & 15 & 13 \\
\hline Região - Sul & 14 & 4 & 1 \\
\hline Região - Nordeste & 16 & 12 & 12 \\
\hline Região - Centro Oeste & 4 & 3 & 2 \\
\hline $\begin{array}{l}\text { Universidades ou institutos de } \\
\text { pesquisa }\end{array}$ & 25 & 15 & 12 \\
\hline Empresas de consultoria & 8 & 6 & 6 \\
\hline
\end{tabular}




\subsection{Avaliação da aplicabilidade das propostas em estudo de caso}

A avaliação das dificuldades encontradas para aplicação prática das propostas discutidas no trabalho foi efetuada a partir de um estudo de caso em uma obra de manutenção de fachada realizada numa edificação residencial localizada na cidade de Recife, Pernambuco. Dados precisos de identificação do prédio não são apresentados, a fim de preservar os interesses dos moradores.

Indicada por um antigo morador do prédio em virtude de um trabalho similar realizado em outra edificação, a consultoria ${ }^{39}$ foi procurada pelo condomínio com o objetivo de avaliar as necessidades do prédio para a realização de substituição completa do revestimento original de fachada do prédio, em pastilhas foscas de $(25 \times 25) \mathrm{mm}$, por placas cerâmicas do tipo semi-grês e porcelanizadas. Precedendo ao serviço de consultoria, o condomínio já havia contratado escritório para elaboração do projeto de arquitetura.

O primeiro contato efetuado pelo condomínio ocorreu em outubro de 2006. Segundo informado naquela oportunidade, a comissão de moradores definida para a realização dos serviços havia feito uma tomada inicial de preços no mercado para a execução da obra, e as propostas apresentaram grandes distorções de valores, prazos e procedimentos, o que motivou a contratação da consultoria.

Além da remodelagem da fachada, havia também a intenção de se realizar outras atividades de menor porte, como a execução de uma nova guarita e a remodelação completa do pavimento mezanino, onde se encontra o salão de festas, piscina, sauna e área de lazer. Essas obras paralelas ainda não estavam acordadas entre os condôminos, em especial por conta do receio quanto aos altos custos envolvidos na fachada e o impreciso conhecimento a respeito dos reais valores totais envolvidos.

A edificação teve a sua construção concluída em 1990 e possui 22 pavimentos, com dois apartamentos por andar, totalizando 40 unidades, além de uma laje para salão de festas e uma garagem semi enterrada.

\footnotetext{
${ }^{39}$ Trabalho acompanhado pelo autor da pesquisa pela empresa de consultoria Tecomat Ltda.
} 
O prédio foi executado no sistema estrutural reticulado em concreto armado e apresenta configuração arquitetônica com os cômodos principais de conforto voltados para o lado leste (nascente), e os cômodos de serviço (caixa de escada, cozinha, área de serviço etc.) para oeste, poente.

O revestimento externo original era todo em pastilhas cerâmicas foscas nas cores branca e preta, com área total de fachada de $5.300 \mathrm{~m}^{2}$. Apenas em poucos espalhados havia ocorrência de trechos com descolamento do revestimento original, em pequena quantidade.

Após o primeiro contato realizado entre as partes, a consultoria apresentou aos condôminos proposta para execução das três atividades macro discutidas na presente pesquisa, que são a investigação das necessidades do prédio, a análise dos critérios para a contratação da empresa executante e, por fim, o acompanhamento. Cabe salientar que foram discutidas as necessidades de cada uma das etapas, deixando ao condomínio a opção de contratar todos os serviços ou apenas aqueles de maior interesse. Nesse caso, foi escolhida a alternativa completa de atividades.

Uma vez que a substituição do revestimento da fachada estava acordada por todos, num primeiro momento a consultoria realizou o trabalho de investigação das necessidades da edificação para a execução desses serviços, a partir de um laudo diagnóstico contemplando a avaliação do revestimento existente por meio da realização de ensaios de resistência de aderência à tração direta exclusivamente na argamassa de emboço, em 42 pontos espalhados pela fachada.

Após a conclusão dos ensaios em janeiro de 2007, cujos resultados se mostraram satisfatórios para o emboço, foram definidos os procedimentos executivos a serem adotados durante a obra, iniciando pela demolição e remoção do revestimento original até a limpeza final da fachada, nesse momento já em comum acordo com a equipe de arquitetura responsável pelo projeto para se ajustar com detalhes as especificações dos materiais utilizados.

A etapa seguinte foi a discussão dos prazos para entrega da obra e os respectivos custos. Para obras dessa natureza, os tempos necessários para a realização de serviços, em geral, são mais difíceis de determinar com precisão, uma vez que a quantidade de fatores de 
interferência é maior do que em obras novas. Entretanto, a partir da experiência em outros serviços similares, foi feita uma estimativa de 12 meses corridos para conclusão da obra.

A previsão das frentes de serviço atuantes na obra em função da expectativa da ocorrência de chuvas e de interdição das áreas sociais do prédio era um item determinante para a definição dos prazos e, especialmente, para a quantidade de equipamentos necessários para a obra.

Considerando a maior incidência de chuva na cidade durante os meses de março a agosto, com ventos incidindo no sentido terra-mar, e a previsão de início dos serviços para setembro, foi recomendado que as atividades começassem pelas fachadas norte e leste, seguindo posteriormente para os panos sul e oeste, mais protegidos das intempéries. Com isso, a fachada principal leste ficaria concluída mais rápido, liberando também as áreas sociais de piscina e lazer aos moradores.

Definidos os prazos e equipamentos foi elaborada planilha orçamentária básica, a ser utilizada com o objetivo de orientar os condôminos quanto aos custos totais previstos para a obra e para servir como referência para o envio das propostas de preços das empresas concorrentes. Para isso, foi efetuado rigoroso levantamento das áreas de serviço da fachada, separadas e identificadas em planilha eletrônica por trechos, a fim de evitar quaisquer dúvidas que pudessem ocorrer durante o transcorrer dos serviços em função de trechos eventualmente não contemplados.

Importante destacar que, apesar dessas quantidades já terem sido estimadas e apresentadas pela empresa de arquitetura responsável pelo projeto, o levantamento definitivo foi efetuado "in loco", reduzindo a possibilidade de ocorrência de áreas "sombreadas", não identificadas no projeto, como realmente aconteceu.

Nessa etapa do serviço ainda havia uma indefinição por parte dos condôminos a respeito da utilização de placas de porcelanato na fachada, cujos custos são maiores em comparação com as placas do tipo semi-grês. Porém, com a separação das áreas por trechos da fachada foi possível apresentar uma estimativa de custos relacionados com as alternativas discutidas pelos condôminos, junto com a equipe de arquitetura, para definição final do projeto. Para a definição dos preços adotados como referenciais foram tomados valores utilizados por empresas da região em obras similares. 
A partir da definição das áreas e suas quantidades, o condomínio pôde realizar a cotação de preços para aquisição das placas cerâmicas, único insumo sob cuja responsabilidade recaía a compra. As especificações técnicas seguiram as determinações apresentadas pela equipe de arquitetura em conjunto com a consultoria.

Em paralelo à definição de quantidades foram apresentados ao condomínio para discussão os aspectos contratuais que envolviam formas de pagamento, documentos e exigências para habilitação das empresas, prazos, detalhes de comportamento dos funcionários, entre outros. Essas considerações foram encaminhadas para análise e receberam pequenos ajustes decorrentes das necessidades específicas da obra.

Em março de 2007 foi concluído o documento (Edital) disponibilizado para as empresas concorrentes à obra, contemplando os aspectos e exigências contratuais, a descrição do escopo dos serviços (materiais e procedimentos executivos), a planilha básica de referência, com os itens de serviço definidos, porém sem preços e quantidades, e os dispositivos gerais de segurança e comportamento dos operários. Além disso, as empresas ainda dispunham do jogo completo de plantas elaborado pelo escritório de arquitetura, razão pela qual todas as informações foram agrupadas em mídia eletrônica (CD) para facilitar a análise.

A escolha das empresas convidadas a participar do processo de concorrência se deu a partir da indicação de pessoas ligadas ao condomínio e da visualização de placas na cidade em obras similares, e também aquelas empresas que já haviam encaminhado proposta antes mesmo da contratação da consultoria.

Durante o mês de abril de 2007 as empresas compareceram no condomínio para obter o CD com os dados e realizar a vistoria no local para avaliação da obra, atividade entendida essencial para que os profissionais envolvidos na elaboração da proposta e eventual execução dos serviços possam conhecer com mais detalhes as circunstâncias que cercam o serviço.

Ao final do período quatro empresas apresentaram proposta de preços para a obra, cujos valores aproximados foram $R \$ 395.000,00, R \$ 442.000,00, R \$ 503.000,00$, e $\mathrm{R} \$ 570.000,00$, enquanto a referência prevista era de $\mathrm{R} \$ 428.000,00$. Observa-se uma variação de $25 \%$ entre a proposta mais discrepante e a referência. 
Cabe ressaltar que, nesse caso, apenas os itens de serviço haviam sido apresentados como referência, de modo que não apenas os preços, mas também as quantidades descritas nas propostas poderiam apresentar variações, indicando a eficiência das ações propostas precedentes à coleta de preços.

Após a entrega das propostas a consultoria compilou os dados em planilha eletrônica dispondo numa mesma tabela cada um dos itens propostos pelas empresas e a referência, com o objetivo de auxiliar a avaliação. Além disso, numa outra planilha os itens foram classificados por peso, a fim de facilitar a negociação de valores. Interessante notar que a existência de quatro propostas diferentes ajudou também a consultoria a verificar eventuais erros seus de levantamento, especialmente os quantitativos.

Durante os meses de maio e junho foram realizadas reuniões individuais com cada uma das empresas a fim de discutir a proposta apresentada e solucionar dúvidas diversas surgidas. Nessas ocasiões eram realizadas as conferências de quantitativos e também ratificadas as exigências para habilitação, e as empresas também tinham a oportunidade de propor alterações em quaisquer das considerações descritas no edital.

Além das questões técnicas e operacionais, também eram discutidos os preços propostos, a partir dos valores admitidos como referenciais e das outras empresas, de modo que às mesmas ficava facultada a possibilidade de ajuste das propostas a partir das discussões realizadas nas reuniões.

Com a entrega final das propostas, em julho foi escolhida empresa para execução dos serviços que, cabe destacar, não apresentou o menor dos valores, mas foi a que esteve mais próxima dos preços adotados como referenciais. O critério de escolha, portanto, não foi apenas o preço, mas também aspectos qualitativos por se tratar de uma empresa com maior tempo de existência no mercado e dispor de balancins elétricos próprios, considerado um diferencial em comparação com as outras empresas que propuseram equipamentos manuais.

Assim, finalmente em agosto de 2007 foram iniciadas as obras, não sem antes serem realizadas vistorias nas áreas comuns e na cobertura para identificação de eventuais problemas, além da natural exigência de controle dos aspectos de segurança dos balancins e das telas de proteção. 
Desde agosto até o mês de janeiro, o cronograma de execução dos serviços foi acompanhado para avaliação de atrasos que pudessem comprometer o final dos serviços, além de reuniões constantes com a comissão de reforma dos condôminos para se discutir as ações tomadas e a evolução dos serviços.

Após a demolição das pastilhas originais da fachada norte foram identificados trechos de desprendimento entre o chapisco original e a base de concreto, o que exigiu a elaboração de um procedimento executivo para tal tratamento, tomado como referência para apresentação de proposta pela empresa executante desse serviço adicional. A proposta foi analisada pela consultoria, comparada com preços cobrados na região em serviços similares, e aprovada para execução.

No mês de dezembro foram realizados ensaios de resistência de aderência para efeito de controle tecnológico em 24 pontos espalhados pela fachada leste, pano em que as placas cerâmicas já apresentavam mais de 28 dias de aplicadas.

Como se pôde perceber ao longo desse relato das atividades de consultoria realizadas na obra, as propostas apresentadas na presente pesquisa foram adotadas de forma orientada no caso em estudo, e as suas repercussões estão apresentadas no Capítulo 7, que destaca a análise da validação. 


\section{ANÁLISE DA VALIDAÇÃO}

Neste capítulo são apresentados os resultados obtidos no estudo e as suas repercussões para a validação. A avaliação da adequação das ações descritas nos capítulos anteriores é verificada a partir da validação das ações propostas, realizada por meio de consulta efetuada a especialistas. Em seguida são descritas considerações levantadas com a implantação das propostas em um estudo de caso prático. Ao final é apresentado o método de gestão considerado validado.

\subsection{Validação interna de conteúdo}

Conforme anteriormente comentado, os questionamentos elaborados e apresentados para discussão junto aos especialistas representam as propostas para cada uma das atividades a serem executadas durante o gerenciamento das atividades de manutenção em fachadas.

O método Delphi tem como objetivo principal a prospecção do comportamento futuro de uma determinada ação, a partir da opinião de especialistas, entretanto, os critérios adotados para a avaliação das respostas é subjetivo, cabendo ao pesquisador extrair dos dados coletados o maior número possível de informações consideradas relevantes para o seu estudo.

Na presente pesquisa foram apresentadas, na primeira rodada, 45 questões que indagavam o grau de importância da realização de atividades diversas propostas no método desenvolvido ao longo do estudo, cujas respostas poderiam ser de I a IV (I - irrelevante, II Pouco relevante, III - Muito relevante, IV - Imprescindível). Além dessas, o especialista poderia optar por não responder (0 - NR), ou indicar sem opinião (5 - SO).

Foram realizadas duas rodadas de questionamentos, a fim de que os participantes pudessem rever as suas respostas com base nos comentários apresentados pelo grupo e pelo coordenador da pesquisa, conforme prevê o método.

Com isso, para efeito de análise foram utilizados os resultados obtidos na segunda rodada de pesquisa, e os critérios de avaliação adotados estão a seguir descritos na Tabela 14. Como já descrito na Figura 9, os valores percentuais utilizados para as análises foram 
tomados apenas dentre as respostas que expressaram algum tipo de opinião (I, II, III ou IV), ou seja, foram excluídas do total as indicativas de NR (não respondeu) ou SO (sem opinião).

Tabela 14 - Critérios de análise das respostas adotados na pesquisa

\begin{tabular}{|c|c|c|}
\hline CLASSE & AVALIAÇÃO & CRITÉRIO \\
\hline A & $\begin{array}{l}\text { Propostas consideradas essenciais para } \\
\text { o desenvolvimento das atividades. }\end{array}$ & $\begin{array}{l}\text { - Percentual obtido como imprescindível (IV) igual ou } \\
\text { superior a } 80 \% \text {. }\end{array}$ \\
\hline B & $\begin{array}{l}\text { Aprovação dos itens com pequenas } \\
\text { ressalvas, com suas propostas } \\
\text { entendidas como importantes, porém } \\
\text { com diferentes escalas de prioridade em } \\
\text { comparação com os demais. }\end{array}$ & $\begin{array}{l}\text { - Somatório dos percentuais obtidos como } \\
\text { imprescindível (IV) e muito relevante (III) igual ou } \\
\text { superior a } 75 \% \text {; e } \\
\text { - Percentual obtido como imprescindível (IV) inferior } \\
\text { a } 80 \% \text {. }\end{array}$ \\
\hline C & $\begin{array}{l}\text { As propostas foram reformuladas, com } \\
\text { base nas considerações apresentadas. }\end{array}$ & $\begin{array}{l}\text { - Somatório dos percentuais obtidos como } \\
\text { irrelevante (I) e pouco relevante (II) superior a } 20 \% \text {. }\end{array}$ \\
\hline
\end{tabular}

Dentre as propostas enquadradas na classe $B$, entendidas como importantes com a realização de algumas ressalvas, foi adotado o critério descrito na Tabela 15 para definição das escalas de prioridades.

Tabela 15 - Critério adotado para definição das escalas de prioridade dentre as propostas enquadradas na classe B.

\begin{tabular}{c|c|c}
\hline CLASSE & PRIORIDADE & CRITÉRIO (além daqueles descritos na classe B) \\
\hline B1 & Alta & - $\quad$ Percentual obtido como imprescindível (IV) entre 61\% e 80\%. \\
\hline B2 & Média & - $\quad$ Percentual obtido como imprescindível (IV) entre 40\% e 60\%. \\
\hline B3 & Baixa & - $\quad$ Percentual obtido como imprescindível (IV) abaixo de 40\%. \\
\hline
\end{tabular}

Consideração importante a fazer é que nenhuma das atividades propostas no trabalho foi avaliada pelos especialistas como prejudicial ao andamento dos serviços, de modo que as mesmas foram apenas classificadas em diferentes graus de importância ou prioridade, confirmando a adequada interpretação dos problemas discutidos nos estudos dos casos não orientados, discutidos no Capítulo 3, e também estudados na abordagem teórica. Nos campos destinados aos comentários também não foram sugeridas atividades adicionais àquelas propostas ao longo do estudo. 
Para uma melhor discussão das respostas, as considerações importantes obtidas em cada questionamento são discutidas a seguir individualmente, cada qual dentro do seu grupo de estudo.

\subsubsection{Aspectos fundamentais da proposta}

Os aspectos fundamentais da proposta, cujos resultados estão apresentados na Tabela 16, tratam das ações "macro" a serem seguidas durante a realização da gestão, a partir das quais são definidas as atividades específicas referentes a cada uma.

Tabela 16 - Resultados obtidos nos questionamentos referentes ao Grupo 1: Aspectos fundamentais da proposta metodológica (I - Irrelevante, II - Pouco relevante, III - Muito relevante, IV - Imprescindível)

\begin{tabular}{|c|c|c|c|c|c|c|}
\hline $\mathbf{N}^{\circ}$ & QUESTIONAMENTO & CLASSE & $\mathbf{I}$ & II & III & IV \\
\hline \multirow{2}{*}{1} & \multirow{2}{*}{ Preparação do diagnóstico das necessidades da obra. } & \multirow{2}{*}{ A } & $0 \%$ & $0 \%$ & $8 \%$ & $92 \%$ \\
\hline & & & \multicolumn{2}{|c|}{$0 \%$} & \multicolumn{2}{|c|}{$100 \%$} \\
\hline \multirow{2}{*}{2} & \multirow{2}{*}{$\begin{array}{l}\text { Discussão dos prazos e custos para a execução dos } \\
\text { serviços }\end{array}$} & \multirow{2}{*}{ B1 } & $0 \%$ & $0 \%$ & $31 \%$ & $69 \%$ \\
\hline & & & \multicolumn{2}{|c|}{$0 \%$} & \multicolumn{2}{|c|}{$100 \%$} \\
\hline \multirow{2}{*}{3} & \multirow{2}{*}{$\begin{array}{l}\text { Definição dos critérios e regras para seleção das } \\
\text { empresas concorrentes }\end{array}$} & \multirow{2}{*}{ B3 } & $0 \%$ & $4 \%$ & $58 \%$ & $38 \%$ \\
\hline & & & \multicolumn{2}{|c|}{$4 \%$} & \multicolumn{2}{|c|}{$96 \%$} \\
\hline \multirow{2}{*}{4} & \multirow{2}{*}{$\begin{array}{l}\text { Discussão dos aspectos técnicos, operacionais e } \\
\text { financeiros envolvidos na contratação. }\end{array}$} & \multirow{2}{*}{ B1 } & $0 \%$ & $0 \%$ & $31 \%$ & $69 \%$ \\
\hline & & & \multicolumn{2}{|c|}{$0 \%$} & \multicolumn{2}{|c|}{$100 \%$} \\
\hline \multirow{2}{*}{5} & \multirow{2}{*}{ Acompanhamento e fiscalização dos serviços } & \multirow{2}{*}{ B1 } & $0 \%$ & $0 \%$ & $27 \%$ & $73 \%$ \\
\hline & & & \multicolumn{2}{|c|}{$0 \%$} & \multicolumn{2}{|c|}{$100 \%$} \\
\hline
\end{tabular}

Observa-se que a preparação do diagnóstico das necessidades se apresenta como uma atividade primordial para o sucesso da gestão, uma vez que irá servir como um instrumento balizador para a definição das ações posteriores.

As demais etapas foram entendidas como importantes, num nível alto de prioridade para todas, a menos na questão da definição de critérios e regras para seleção das empresas. Interessante notar nesse item que todos os comentários apresentados pelos especialistas foram no sentido de afirmar a necessidade dessa discussão, o que é um 
indicativo de que a interpretação dada é que, dentre as demais atividades do grupo, essa pode ser considerada a menos importante, porém necessária.

\subsubsection{Diagnóstico das necessidades do prédio}

Na Tabela 17 são apresentados os resultados obtidos nos questionamentos que tratam das atividades propostas para a determinação do diagnóstico das necessidades do edifício, etapa julgada essencial para o sucesso da gestão. Interessante que, nesse grupo, alguns questionamentos foram elaborados utilizando escalas com maneiras de interpretação diferentes das demais, e por isso serão tratadas em separado.

Tabela 17 - Resultados obtidos nos questionamentos referentes ao Grupo 2: Diagnóstico das necessidades (I Irrelevante, II - Pouco relevante, III - Muito relevante, IV - Imprescindível)

\begin{tabular}{|c|c|c|c|c|c|c|}
\hline $\mathbf{N}^{\circ}$ & QUESTIONAMENTO (indicar o grau de importância) & CLASSE & $\mathbf{I}$ & II & III & IV \\
\hline \multirow{2}{*}{6} & \multirow{2}{*}{$\begin{array}{l}\text { Utilizar uma metodologia padrão para a elaboração de um } \\
\text { correto diagnóstico das necessidades. }\end{array}$} & \multirow{2}{*}{ B3 } & $0 \%$ & $4 \%$ & $73 \%$ & $23 \%$ \\
\hline & & & \multicolumn{2}{|c|}{$4 \%$} & \multicolumn{2}{|c|}{$96 \%$} \\
\hline \multirow{2}{*}{7} & \multirow{2}{*}{$\begin{array}{l}\text { Coleta das seguintes informações para uma adequada } \\
\text { investigação do caso: idade do prédio, posicionamento das } \\
\text { fachadas, materiais e procedimentos utilizados na época da } \\
\text { construção, solução estrutural. }\end{array}$} & \multirow{2}{*}{ A } & $0 \%$ & $3 \%$ & $14 \%$ & $83 \%$ \\
\hline & & & \multicolumn{2}{|c|}{$3 \%$} & \multicolumn{2}{|c|}{$97 \%$} \\
\hline \multirow{2}{*}{8} & \multirow{2}{*}{$\begin{array}{l}\text { Coleta das seguintes informações para uma adequado } \\
\text { diagnóstico das necessidades do caso: projeção esquemática da } \\
\text { fachada, contemplando cotas, estado de conservação, evolução } \\
\text { (tempo e local de ocorrência) de eventuais problemas, } \\
\text { atividades de manutenção já realizadas. }\end{array}$} & \multirow{2}{*}{ B1 } & $0 \%$ & $3 \%$ & $34 \%$ & $63 \%$ \\
\hline & & & \multicolumn{2}{|c|}{$3 \%$} & \multicolumn{2}{|c|}{$97 \%$} \\
\hline \multirow{2}{*}{9} & \multirow{2}{*}{$\begin{array}{l}\text { Realização de pesquisa junto aos usuários para identificação de } \\
\text { informações eventualmente não verificadas na coleta inicial. }\end{array}$} & \multirow{2}{*}{ C } & $0 \%$ & $23 \%$ & $69 \%$ & $8 \%$ \\
\hline & & & \multicolumn{2}{|c|}{$23 \%$} & \multicolumn{2}{|c|}{$77 \%$} \\
\hline \multirow{2}{*}{10} & \multirow{2}{*}{$\begin{array}{l}\text { Realização de ensaios de resistêcia de aderência à tração direta } \\
\text { para os revestimentos aderidos. }\end{array}$} & \multirow{2}{*}{ B2 } & $0 \%$ & $8 \%$ & $48 \%$ & $44 \%$ \\
\hline & & & \multicolumn{2}{|c|}{$8 \%$} & \multicolumn{2}{|c|}{$92 \%$} \\
\hline \multirow{2}{*}{10.1} & \multirow{2}{*}{$\begin{array}{l}\text { Realização de ensaios de resistêcia de aderência à tração direta } \\
\text { para os revestimentos aderidos, caso a edificação apresente } \\
\text { algum problema visual de desplacamento, indicando a } \\
\text { necessidade de uma manutenção CORRETIVA. }\end{array}$} & \multirow{2}{*}{ B1 } & $4 \%$ & $0 \%$ & $27 \%$ & $69 \%$ \\
\hline & & & \multicolumn{2}{|c|}{$4 \%$} & \multicolumn{2}{|c|}{$96 \%$} \\
\hline
\end{tabular}




\begin{tabular}{|c|c|c|c|c|c|c|}
\hline \multirow{2}{*}{10.2} & $\begin{array}{l}\text { Realização de ensaios de resistêcia de aderência à tração direta } \\
\text { para os revestimentos aderidos, caso a edificação não apresente }\end{array}$ & \multirow{2}{*}{ C } & $12 \%$ & $50 \%$ & $38 \%$ & $0 \%$ \\
\hline & $\begin{array}{l}\text { problema visual de desplacamento, indicando eventual } \\
\text { necessidade de manutenção apenas PREVENTIVA. }\end{array}$ & & \multicolumn{2}{|c|}{$62 \%$} & \multicolumn{2}{|c|}{$38 \%$} \\
\hline \multirow{2}{*}{11} & $\begin{array}{l}\text { Indique a sua opinião sobre a execução de } 1 \text { pano de ensaio } \\
\text { (composto por } 6 \text { pontos de arrancamento) a cada } 1.000 \mathrm{~m} 2 \text { de }\end{array}$ & \multirow{2}{*}{ POUCO } & $18 \%$ & $50 \%$ & $23 \%$ & $9 \%$ \\
\hline & $\begin{array}{l}\text { fachada, em locais espalhados ao longo dos pavimentos ( } 1 \text { - mto } \\
\text { pouco, } 2 \text { - pouco, } 3 \text { - satisfatório, } 4 \text { - excessivo). }\end{array}$ & & & & & \\
\hline \multirow{2}{*}{11.1} & \multirow{2}{*}{$\begin{array}{l}\text { A definição da quantidade de pontos necessários para a } \\
\text { avaliação das necessidade do caso é subjetiva, a depender da } \\
\text { situação em que a edificação se encontra ( } 2 \text { - não concordo; } 3 \text { - } \\
\text { concordo; } 5 \text { - sem opinião). }\end{array}$} & \multirow{2}{*}{ CONC } & & $28 \%$ & $74 \%$ & \\
\hline & & & & & & \\
\hline \multirow{2}{*}{12} & \multirow{2}{*}{$\begin{array}{l}\text { Realização de ensaios de percussão como auxiliar para o } \\
\text { diagnóstico e extensão das necessidades da obra. }\end{array}$} & \multirow{2}{*}{ B2 } & $0 \%$ & $8 \%$ & $36 \%$ & $56 \%$ \\
\hline & & & \multicolumn{2}{|c|}{$8 \%$} & \multicolumn{2}{|c|}{$92 \%$} \\
\hline \multirow{2}{*}{13} & \multirow{2}{*}{$\begin{array}{l}\text { Indique o nível de segurança e confiabilidade, com os meios } \\
\text { técnicos disponíveis atualmente, de se balizar nos ensaios de } \\
\text { aderência e percussão para a avaliação das necessidades da obra } \\
\text { (1 - mto baixo, } 2 \text { - baixo, } 3 \text { - satisfatório, } 4 \text { - excelente). }\end{array}$} & \multirow{2}{*}{ SATISF } & $0 \%$ & $32 \%$ & $64 \%$ & $4 \%$ \\
\hline & & & & & & \\
\hline \multirow{2}{*}{14} & \multirow{2}{*}{$\begin{array}{l}\text { Apresentação de soluções técnicas para a execução dos serviços, } \\
\text { apontando vantagens e desvantagens, com base no prognóstico } \\
\text { da evolução da conservação da fachada e dos seus } \\
\text { componentes. }\end{array}$} & \multirow{2}{*}{ A } & $0 \%$ & $0 \%$ & $35 \%$ & $65 \%$ \\
\hline & & & \multicolumn{2}{|c|}{$0 \%$} & \multicolumn{2}{|c|}{$100 \%$} \\
\hline \multirow{2}{*}{15} & \multirow{2}{*}{$\begin{array}{l}\text { Discussão dos seguintes aspectos para cada solução: estimativa } \\
\text { de custos e prazos, transtornos envolvidos, âmbito da garantia } \\
\text { ofertada pelos construtores, riscos envolvidos, necessidade } \\
\text { futura de manutenção, valorização comercial. }\end{array}$} & \multirow{2}{*}{ B1 } & $0 \%$ & $3 \%$ & $26 \%$ & $71 \%$ \\
\hline & & & \multicolumn{2}{|c|}{$3 \%$} & \multicolumn{2}{|c|}{$97 \%$} \\
\hline
\end{tabular}

Para uma melhor avaliação dos dados, esse grupo pode ser dividido em fases que representam etapas distintas do desenvolvimento da ação, quais sejam: aspectos gerais (questão 6), investigação das necessidades (questões 7 a 9), ensaios (questões 10 a 13) e discussão de alternativas (questões 14 e 15).

A utilização de uma metodologia padrão para a elaboração do diagnóstico foi tida pelos especialistas como importante, porém com escala baixa de prioridade. A idéia dessa padronização tem por objetivo auxiliar o profissional como uma espécie de "roteiro", 
evitando eventuais esquecimentos, e facilitar comparações entre avaliações realizadas em casos ou épocas distintos. A partir dessa ótica, entende-se o padrão apenas como um modelo no qual constam as questões básicas e essenciais, passível, porém, de alterações de acordo com as necessidades da obra.

No tocante à investigação das necessidades da obra, a coleta de informações básicas a respeito da edificação é considerada importante, mesmo que a intervenção na fachada não esteja sendo motivada por algum tipo de problema. A depender do caso, o grau de influência de cada dado coletado poderá ser diferente, mas de certo modo todos podem ser relevantes.

A proposta da realização de pesquisa junto aos usuários para coleta de informações eventualmente não verificadas na vistoria pode ser interpretada como de menor importância pelos especialistas. Cabe ressaltar que a idéia é que a pesquisa sirva apenas como mais um instrumento de coleta de informações para ajudar na avaliação das necessidades do caso, devendo-se, inclusive, atentar para a confiabilidade dessas informações. Assim, a sua realização pode ficar restrita aos casos em que o profissional julgue necessário, especialmente para obter informações disponíveis com usuários mais antigas, que utilizam o bem há mais tempo, e conhecem o seu comportamento sazonal ao longo do tempo (anual, semestral etc.).

Os aspectos que tratam dos ensaios necessários para a análise dos problemas de fachada foram os mais discutidos pelos especialistas dentro desse grupo, e envolveram os ensaios de resistência de aderência à tração direta e os de percussão.

As indagações apresentadas nos comentários tratavam não apenas da real necessidade dos ensaios, e por conseqüência dos custos e transtornos envolvidos, mas também da sua amostragem. Por conta disso, na segunda rodada foram incluídos três novos questionamentos para tentar melhor elucidar as opiniões dos participantes.

A análise dos dados obtidos na pesquisa indica que tanto os ensaios de resistência de aderência como de percussão são considerados importantes para o diagnóstico das necessidades do prédio, com uma escala de prioridade média, em ambos os casos.

Os ensaios de aderência, mais complexos e onerosos que os de percussão, foram julgados como de alta prioridade para os casos em que se trata de uma atividade de 
manutenção corretiva, onde a edificação apresenta queda do revestimento. A proposta prevê que os testes sejam realizados em pontos diversos espalhados na edificação, preferencialmente em pavimentos distintos. É mais trabalhoso, pois exige montagem de equipamento (balancim individual, pelo menos), mas permite uma melhor visualização do problema, inclusive separando a avaliação da fachada por trechos.

Já quando se tratar de uma atividade de manutenção apenas de caráter preventiva, que a edificação não apresente nenhum tipo de problema, o julgamento foi de que a sua realização pode ocorrer quando o condomínio solicitar uma análise mais apurada, como um histórico para efeito de previsão das atividades futuras de manutenção, fato muito raro de acontecer. Nessas situações, o ensaio de percussão, a despeito da sua menor precisão, foi apontado por alguns especialistas como mais indicado, uma vez que possibilita maior amostragem devido à facilidade de execução e menor custo.

A quantidade e amostragem dos ensaios de aderência a serem realizados também geraram bastante discussão. Foi apresentada proposta de um pano de ensaio, composto por seis pontos de arrancamento, a cada $1000 \mathrm{~m}^{2}$ de fachada, que foi considerado pouco por $50 \%$ dos especialistas. Em verdade, $76 \%$ dos pesquisados entenderam que a definição da quantidade de pontos é subjetiva, a depender da situação em que a edificação se encontra. Porém, importante destacar que a utilização dos dados obtidos nos ensaios de aderência só deve ocorrer caso a quantidade de pontos avaliados possa ser considerada representativa do todo, pelo menos superior a 6 amostras a cada $1000 \mathrm{~m}^{2}$ de fachada.

Discutindo especialmente o ensaio de percussão, interessante notar a concordância dos respondentes de que se trata de mais um instrumento de análise para avaliação das necessidades de intervenção na fachada, podendo servir como o prenúncio de um problema futuro, principalmente quando não há problemas aparentes. Apresenta a subjetividade como principal desvantagem, que pode ser atenuada pela possibilidade de grande amostragem decorrente do seu baixo custo.

Por fim, ainda relativo aos ensaios, o julgamento apresentado pelos especialistas é de que o nível de segurança e confiabilidade dos ensaios de aderência e percussão para avaliação das necessidades da edificação, associado às demais informações previamente discutidas, pode ser considerado satisfatório, com os meios técnicos disponíveis atualmente. 
É evidente que se deve ter bastante cuidado com as interpretações desses ensaios e, em algumas situações, serão necessários outros ensaios de avaliação, mas dadas as atuais circunstâncias é possível de obter dados confiáveis e seguros.

A discussão das alternativas de intervenção após o diagnóstico das necessidades do prédio, incluindo vantagens, desvantagens, prazos, transtornos envolvidos, valorização comercial, entre outros, foi também considerada essencial para o sucesso, antecipando questionamentos que fatalmente serão apresentados pelos condôminos.

\subsubsection{Análises e critérios para a contratação}

A Tabela 18 apresenta discussões referentes aos prazos e custos envolvidos na realização das intervenções apontadas no diagnóstico das necessidades do prédio, envolvendo questões de orçamento e planejamento.

Tabela 18 - Resultados obtidos nos questionamentos referentes ao Grupo 3: Discussão de prazos e custos (I - Irrelevante, II - Pouco relevante, III - Muito relevante, IV - Imprescindível)

\begin{tabular}{|c|c|c|c|c|c|c|}
\hline $\mathbf{N}^{\circ}$ & QUESTIONAMENTO (indicar o grau de importância) & CLASSE & $\mathbf{I}$ & II & III & IV \\
\hline \multirow{2}{*}{16} & \multirow{2}{*}{$\begin{array}{l}\text { Discutir com o condomínio os aspectos relacionados com o prazo } \\
\text { de execução dos serviços, levando-se em conta aspectos como: } \\
\text { riscos de um eventual adiamento, transtornos, impactos } \\
\text { financeiros, influência das condições ambientais. }\end{array}$} & \multirow{2}{*}{ B1 } & $0 \%$ & $4 \%$ & $27 \%$ & $69 \%$ \\
\hline & & & \multicolumn{2}{|c|}{$4 \%$} & \multicolumn{2}{|c|}{$96 \%$} \\
\hline \multirow{2}{*}{17} & \multirow{2}{*}{$\begin{array}{l}\text { Existência de um modelo padrão de planilha para a elaboração } \\
\text { do orçamento básico das obras, passível de adaptação para cada } \\
\text { caso. }\end{array}$} & \multirow{2}{*}{ B3 } & $0 \%$ & $8 \%$ & $62 \%$ & $31 \%$ \\
\hline & & & \multicolumn{2}{|c|}{$8 \%$} & \multicolumn{2}{|c|}{$92 \%$} \\
\hline \multirow[t]{2}{*}{18} & $\begin{array}{l}\text { Realização do levantamento dos quantitativos no local, e sua } \\
\text { apresentação ao condomínio por trechos separados da fachada }\end{array}$ & \multirow[t]{2}{*}{ B3 } & $0 \%$ & $8 \%$ & $65 \%$ & $27 \%$ \\
\hline & (memória de cálculo), a fim de facilitar as atividades de controle. & & \multicolumn{2}{|c|}{$8 \%$} & \multicolumn{2}{|c|}{$92 \%$} \\
\hline \multirow{2}{*}{19} & $\begin{array}{l}\text { Indique o grau de confiabilidade da cotação de preços de } \\
\text { referência em } 3 \text { fontes diferentes do mercado (empresas, }\end{array}$ & \multirow{2}{*}{ SATISF } & $0 \%$ & $23 \%$ & $62 \%$ & $15 \%$ \\
\hline & $\begin{array}{l}\text { armazéns etc.) para a obtenção do custo final (1 - mto baixo, } 2 \text { - } \\
\text { baixo, } 3 \text { - satisfatório, } 4 \text { - excelente). }\end{array}$ & & & & & \\
\hline
\end{tabular}

Os especialistas classificaram como de alta prioridade a informação aos condôminos a respeito dos prazos para execução, impactos financeiros, transtornos, antecipando futuros 
questionamentos dos envolvidos, com entendimento similar ao da discussão das alternativas de intervenção.

Para o levantamento dos custos foi discutida a proposta de apresentação de um modelo de planilha com os serviços diversos normalmente executados nesse tipo de obra, que as empresas gerenciadoras contratadas pelo condomínio podem consultar para preparar a planilha básica a ser encaminhada às empresas concorrentes para a obra (discutido na questão no 22). As repostas obtidas indicam que tal procedimento apesar de importante, tem pequeno grau de prioridade.

Esse mesmo resultado foi encontrado no tocante ao levantamento dos quantitativos utilizados para o desenvolvimento do orçamento no local, com apresentação ao condomínio por trechos separados da fachada (memória de cálculo), a fim de facilitar as atividades de controle. Esse procedimento visa permitir eventuais ajustes conforme as necessidades e o andamento da obra, facilitando ainda as atividades de medição dos serviços. Nesse caso, importante evitar segmentação excessiva da fachada, que pode até dificultar as avaliações posteriores.

A cotação de preços de referência para a elaboração do orçamento básico junto a três fontes diferentes no mercado (empresas, armazéns) foi considerada satisfatória por $62 \%$ dos pesquisados. Tal cotação é realizada pelo gerenciador e deve ser tomada como base para a elaboração da planilha básica referencial de custos encaminhada ao condomínio antes da seleção das empresas.

As discussões relativas à seleção das empresas para execução dos serviços estão tratadas na Tabela 19. Em obras realizadas em edificações habitadas ou em uso, a contratação desse tipo de serviço é, normalmente, uma atividade complicada em face dos diversos interesses envolvidos, especialmente no tocante aos preços praticados.

Tabela 19 - Resultados obtidos nos questionamentos referentes ao Grupo 4: Seleção das empresas (I - Irrelevante, II - Pouco relevante, III - Muito relevante, IV - Imprescindível)

\begin{tabular}{|c|c|c|c|c|c|c|}
\hline $\mathbf{N}^{\circ}$ & QUESTIONAMENTO (indicar o grau de importância) & CLASSE & I & II & III & IV \\
\hline 20 & Disponibilização para as empresas concorrentes de um & B1 & $0 \%$ & $8 \%$ & $19 \%$ & $73 \%$ \\
\hline
\end{tabular}




\begin{tabular}{|c|c|c|c|c|c|c|}
\hline & $\begin{array}{l}\text { documento formal (Edital) contemplando especificações, } \\
\text { projetos, regras para a contratação, planilha orçamentária de } \\
\text { referência e critério de seleção. }\end{array}$ & & \multicolumn{2}{|c|}{$8 \%$} & \multicolumn{2}{|c|}{$92 \%$} \\
\hline \multirow{2}{*}{21} & $\begin{array}{l}\text { Discussão das seguintes informações a respeito das empresas } \\
\text { concorrentes: comprovação de serviços similares, certidão }\end{array}$ & \multirow{2}{*}{ B3 } & $0 \%$ & $4 \%$ & $62 \%$ & $34 \%$ \\
\hline & $\begin{array}{l}\text { negativa de débitos e capital social (compatível com o porte da } \\
\text { obra). }\end{array}$ & & \multicolumn{2}{|c|}{$4 \%$} & \multicolumn{2}{|c|}{$96 \%$} \\
\hline \multirow{2}{*}{22} & Encaminhamento às empresas concorrentes uma planilha & \multirow{2}{*}{ B3 } & $0 \%$ & $4 \%$ & $64 \%$ & $32 \%$ \\
\hline & todos. & & \multicolumn{2}{|c|}{$4 \%$} & \multicolumn{2}{|c|}{$96 \%$} \\
\hline \multirow{2}{*}{23} & Seleção das empresas não apenas pelo menor preço, mas & \multirow{2}{*}{ A } & $0 \%$ & $0 \%$ & $12 \%$ & $88 \%$ \\
\hline & também pela sua qualificação. & & \multicolumn{2}{|c|}{$0 \%$} & \multicolumn{2}{|c|}{$100 \%$} \\
\hline
\end{tabular}

A proposta de disponibilização de um "edital" formalizado para entrega aos concorrentes tem o objetivo de apresentar de forma clara o máximo de informações necessárias para a perfeita realização dos serviços. As respostas obtidas indicaram um entendimento dos especialistas favorável a essa prática, numa escala alta de prioridade, com a ressalva de que o mesmo deve ser desenvolvido pelo gerenciador, e não pelo condomínio.

A exigência de apresentação pelas empresas concorrentes de comprovação de serviços similares, certidão negativa de débitos e capitão social compatível com o porte da obra foi entendida como importante, numa escala baixa de prioridade em relação a outras ações. A preocupação maior apresentada se refere à possibilidade de excessiva restrição à participação de empresas, o que pode reduzir o número de proponentes para a execução dos serviços.

Também foi entendida na pesquisa como importante, com baixo grau de prioridade, o encaminhamento às empresas concorrentes de uma planilha orçamentária, sem os preços, para preenchimento por cada uma delas. Importante destacar que essa planilha é elaborada pelo gerenciador a partir da cotação de preços básicos de mercado (questão 19) e de um modelo padrão (questão 17) adaptado às condições e características de cada caso.

Os valores estimados em planilha são apresentados exclusivamente ao condomínio, que os tomam como referência dos custos da obra, inclusive para definição das ações para captação dos recursos junto aos demais usuários. No momento da seleção essa planilha é 
enviada às empresas concorrentes, porém sem os preços pesquisados (ou também sem as quantidades, conforme a conveniência do caso), de modo que lhes cabe apenas preencher as colunas faltantes ${ }^{40}$. Isso permite comparar mais facilmente as propostas financeiras, podendo-se facultar às empresas concorrentes sugerir algumas alterações à planilha que, entretanto, devem ser enviadas em separado.

O item que destaca o critério utilizado para seleção da empresa pela sua qualificação e não apenas pelo preço foi apresentado como imprescindível por $88 \%$ dos especialistas, indicando se tratar de um aspecto essencial para o sucesso da obra. Esse entendimento já era esperado, e inclusive ocorre também quando se aborda o assunto junto aos condôminos antes da obtenção das propostas. Porém, quando os preços são apresentados, é também natural que se busque aquela alternativa mais econômica, daí a importância de se restringir a participação de empresas menos qualificadas no processo, bem como de se entregar um edital com as explicações a respeito das regras do serviço.

Os aspectos relacionados com a contratação, etapa que precede o início da execução dos serviços, contemplaram o grupo com maior número de questionamentos, como se pode observar na Tabela 20. Para facilitar a avaliação, as discussões podem também ser segmentadas em três fases distintas: aspectos financeiros (questões 24 a 27), técnicos (questões 28 a 32), e operacionais (questões 33 a 36).

Tabela 20 - Resultados obtidos nos questionamentos referentes ao Grupo 5: Contratação (I Irrelevante, II - Pouco relevante, III - Muito relevante, IV - Imprescindível)

\begin{tabular}{c|l|c|c|c|c|c}
\hline $\mathbf{N}^{\circ}$ & \multicolumn{1}{|c|}{ QUESTIONAMENTO (indicar o grau de importância) } & CLASSE & I & II & III & IV \\
\hline \multirow{2}{*}{24} & $\begin{array}{l}\text { Explicitação em contrato dos seguintes aspectos econômicos: } \\
\text { preços, reajustes, pagamentos, sanções e multas. }\end{array}$ & A & $0 \%$ & $0 \%$ & $15 \%$ & $85 \%$ \\
\cline { 4 - 6 } 25 & $\begin{array}{l}\text { Definição em contrato que os preços e as quantidades } \\
\text { estipulados em contrato sejam irreajustáveis. }\end{array}$ & C & $12 \%$ & $13 \%$ & $50 \%$ & $25 \%$ \\
\cline { 3 - 7 } 25.1 & Definição em contrato que as quantidades estipuladas em & $\mathbf{C}$ & $4 \%$ & $21 \%$ & $21 \%$ & $54 \%$ \\
\hline
\end{tabular}

\footnotetext{
${ }^{40}$ Ver discussão detalhada a respeito das alternativas no item 6.3.
} 


\begin{tabular}{|c|c|c|c|c|c|c|}
\hline & $\begin{array}{l}\text { contrato sejam irreajustáveis, a menos que ocorra alguma } \\
\text { alteração no projeto. }\end{array}$ & & \multicolumn{2}{|c|}{$25 \%$} & \multicolumn{2}{|c|}{$75 \%$} \\
\hline \multirow{2}{*}{25.2} & Definição em contrato que os preços apresentados no & \multirow{2}{*}{ C } & $8 \%$ & $20 \%$ & $40 \%$ & $32 \%$ \\
\hline & alguma alteração profunda na conjuntura econômica. & & \multicolumn{2}{|c|}{$28 \%$} & \multicolumn{2}{|c|}{$72 \%$} \\
\hline \multirow{2}{*}{26} & Discussão com o condomínio das vantagens e desvantagens & \multirow{2}{*}{ C } & $4 \%$ & $20 \%$ & $52 \%$ & $24 \%$ \\
\hline & envolvidas em cada modalidade prevista para o pagamento. & & \multicolumn{2}{|c|}{$24 \%$} & \multicolumn{2}{|c|}{$76 \%$} \\
\hline \multirow{2}{*}{27} & \multirow{2}{*}{$\begin{array}{l}\text { Retenção dos valores pagos à empresa executante para quitação } \\
\text { apenas no final dos serviços. }\end{array}$} & \multirow{2}{*}{ B2 } & $0 \%$ & $12 \%$ & $34 \%$ & $54 \%$ \\
\hline & & & \multicolumn{2}{|c|}{$12 \%$} & \multicolumn{2}{|c|}{$88 \%$} \\
\hline \multirow{2}{*}{28} & \multirow{2}{*}{$\begin{array}{l}\text { Estabelecimento de quantidades mínimas de equipamentos e } \\
\text { pessoal para o início dos serviços. }\end{array}$} & \multirow{2}{*}{ C } & $0 \%$ & $38 \%$ & $46 \%$ & $14 \%$ \\
\hline & & & \multicolumn{2}{|c|}{$38 \%$} & \multicolumn{2}{|c|}{$62 \%$} \\
\hline \multirow{2}{*}{29} & \multirow{2}{*}{$\begin{array}{l}\text { Presença sistemática de um representante técnico da empresa } \\
\text { executante em tempo integral na obra. }\end{array}$} & \multirow{2}{*}{ B3 } & $0 \%$ & $15 \%$ & $65 \%$ & $20 \%$ \\
\hline & & & \multicolumn{2}{|c|}{$15 \%$} & \multicolumn{2}{|c|}{$85 \%$} \\
\hline \multirow{2}{*}{30} & \multirow{2}{*}{$\begin{array}{l}\text { Definição de bônus ou prejuízos no caso de descumprimento dos } \\
\text { prazos pela empresa executante. }\end{array}$} & \multirow{2}{*}{$\mathbf{C}$} & $0 \%$ & $23 \%$ & $50 \%$ & $27 \%$ \\
\hline & & & \multicolumn{2}{|c|}{$23 \%$} & \multicolumn{2}{|c|}{$77 \%$} \\
\hline \multirow{2}{*}{31} & \multirow{2}{*}{$\begin{array}{l}\text { Entrega de um documento final, do tipo "As Built", formalizando } \\
\text { a conclusão e entrega da obra. }\end{array}$} & \multirow{2}{*}{ B1 } & $0 \%$ & $0 \%$ & $24 \%$ & $76 \%$ \\
\hline & & & & & & \\
\hline & Entrega pela empresa executante de um manual de operação, & & $0 \%$ & $0 \%$ & $27 \%$ & $73 \%$ \\
\hline & uso e manutenção após a conclusão dos serviços. & & & & & \\
\hline 2 & Retenção na fonte do pagamento das obrigações fiscais e & & $0 \%$ & $12 \%$ & $56 \%$ & $32 \%$ \\
\hline & trabalhistas nas medições efetuadas pela construtora. & & & & & \\
\hline & Conferência, registro e documentação da quitação dos referidos & & $0 \%$ & $0 \%$ & $32 \%$ & $68 \%$ \\
\hline & pagamentos ao longo da obra. & & & & & \\
\hline & Apresentação da Certidão Negativa de Débitos (CND) antes da & & $9 \%$ & $4 \%$ & $70 \%$ & $17 \%$ \\
\hline & liberação do primeiro pagamento. & & & & & \\
\hline & Investigação prévia (inclusive documentação e registro) das & & $4 \%$ & $13 \%$ & $20 \%$ & $63 \%$ \\
\hline 36 & $\begin{array}{l}\text { áreas diversas da edificação e da vizinhança quanto à } \\
\text { conservação. }\end{array}$ & B1 & & & & \\
\hline
\end{tabular}


Dentre as propostas apresentadas no tocante aos aspectos financeiros, nenhuma daquelas que trataram da definição em contrato de preços e quantidades irreajustáveis foram avaliadas pelos especialistas como essenciais para o bom andamento do serviço. Tal comportamento já havia sido observado na primeira rodada, razão pela qual foram elaboradas questões adicionais mais específicas para que reafirmar o entendimento.

Importante ressaltar que não se trata da explicitação no contrato dos preços, reajustes, pagamentos, sanções e multas, que foi considerada essencial, mas sim a impossibilidade de reajustes ao longo da obra.

Esse procedimento tem o objetivo de impedir que o construtor possa alegar, após o início dos serviços, que determinadas áreas de execução dos serviços não foram previstas em contrato (áreas internas das varandas, áreas sociais do pavimento térreo, por exemplo). Quanto aos preços, a proposta é que os ajustes monetários previamente acordados em contrato (com base no INCC, por exemplo) devem ser mantidos, não se permitindo, porém, reajustes nos preços básicos devido a eventuais dificuldades encontradas pelo executante.

Dentre as considerações apresentadas pelos especialistas se destaca a discussão da imprevisibilidade dos serviços de manutenção em revestimentos de fachada, nos quais as avaliações das necessidades, via de regra, são realizadas por amostragem, e com isso existem possibilidades de alterações, principalmente serviços adicionais necessários e não previstos inicialmente.

Quanto aos preços, também a imprevisibilidade é um fator que concorre de forma negativa para a impossibilidade de reajustes, porém a definição de parâmetros relativos aos reajustes vinculados aos prazos dos serviços e ao tipo de contrato estipulado é uma alternativa interessante para solução do problema.

Também a discussão do gerenciador junto ao condomínio a respeito das possibilidades de pagamento dos serviços (preço global, parcelas fixas mensais, pagamento por medição, empreitada) também não foi interpretada como essencial pela maioria.

Ainda relacionado com os aspectos financeiros, a retenção de valores pagos à empresa executante para o custeio de eventuais problemas surgidos na edificação em decorrência da obra e não ressarcidos pela empresa executante foi considerada uma 
atividade importante para o sucesso do trabalho, com escala média de prioridade em comparação com as demais atividades.

Dentre os aspectos técnicos, não foi considerada como essencial a proposta de se estabelecer uma quantidade mínima de pessoal e equipamentos para o início do serviço com o objetivo de evitar que a obra inicie sem que a empresa executante tenha preparado a infra-estrutura necessária para conseguir alcançar o prazo previsto. Na ânsia de iniciar logo as atividades, o condomínio geralmente é "tentado" a aceitar o começo dos serviços, e início dos transtornos, mesmo sem as condições mínimas necessárias, o que acaba repercutindo no tempo de conclusão da obra. Uma das alegações apresentadas é que o cumprimento do prazo é de responsabilidade da empresa executante, a quem deve caber estipular sua equipe.

Avaliação similar foi apresentada no tocante à determinação de bônus (ou multas) no caso de descumprimento dos prazos pelas empresas executantes, podendo ser mais um critério inibidor à participação de empresas no processo de concorrência, pois as mesmas acabam sujeitas à natural imprevisibilidade do serviço, anteriormente comentada. Para efeito de discussão, cabe destacar que houve atrasos nos prazos de conclusão das obras em todos os casos não orientados discutidos no Capítulo 3.

A presença sistemática de um representante técnico da empresa executante em tempo integral na obra foi entendida pelos especialistas como importante, em um baixo grau de prioridade. O profissional em questão pode ser um mestre (ou encarregado) da obra, que funciona como representante da empresa executante junto ao condomínio e à fiscalização para a tomada de ações diversas importantes ao longo do dia de serviço.

Em obras executadas em edificações habitadas ou em uso, é comum a necessidade de ações imediatas para ajustes de problemas (interdição de áreas de segurança, relocação temporária das equipes de serviço devido ao incômodo causado aos usuários, reparos de quebras de vidros, problemas com a vizinhança), as quais requerem a presença de alguém que responda às solicitações.

As questões relacionadas à formalização da entrega final da obra, por meio da apresentação de um "As Built" e de um manual de operação, uso e manutenção (MOUM) pela empresa construtora após a execução dos serviços foram entendidas como atividades 
importantes, com nível alto de prioridade. Importante destacar que, em ambos os casos, a proposta prevê que a complexidade desses documentos deve variar com o porte do serviço.

Quanto aos aspectos operacionais propostos, todos os itens tiveram uma validação considerada importante, com diferentes graus de prioridade. Com alto índice de prioridade estão a investigação prévia das áreas diversas da edificação e vizinhança quanto à conservação, com o objetivo de evitar que, ao final dos serviços, surjam solicitações ao condomínio para ressarcimento de danos não provenientes da obra, e a devida conferência, registro e documentação dos diversos pagamentos das obrigações fiscais e trabalhista efetuados pela empresa executante ao longo da obra.

Também foi apresentada a proposta do condomínio reter no pagamento das medições os valores correspondentes à quitação das obrigações fiscais e trabalhistas da empresa executante. O problema é que as ações impetradas pelos operários contra a empresa executante podem acabar no condomínio, que legalmente responde solidariamente pela obra.

A despeito da explicitação em contrato de que o condomínio não responde por problemas dessa natureza, caso a interpretação jurídica seja de que o trabalhador tem o direito de receber o que lhe é devido, e a construtora não pagar, quem assume o ônus, como responsável solidário, é o condomínio. É claro que o condomínio poderá reaver tudo posteriormente junto à construtora, mas isso pode demandar algum tempo e transtornos diversos.

A retenção proposta obriga o condomínio a quitar essas obrigações, o que irá demandar um trabalho desnecessário caso a empresa executante apresente regularmente as guias de pagamento. Porém, estando previsto em contrato, o condomínio poderá efetuar a retenção caso a empresa executante não encaminhe as referidas guias quitadas.

Outra questão entendida pelos especialistas como importante, mas com baixo grau de prioridade, é a apresentação da Certidão Negativa de Débitos (CND) antes da liberação do primeiro pagamento. 


\subsubsection{Acompanhamento dos serviços}

Os dados apresentados na Tabela 21 apontam as opiniões dos especialistas quanto às atividades desenvolvidas durante o acompanhamento da execução da obra, que pode ser dividido em aspectos de caráter técnico e operacional.

Tabela 21 - Resultados obtidos nos questionamentos referentes ao Grupo 6: Acompanhamento (I Irrelevante, II - Pouco relevante, III - Muito relevante, IV - Imprescindível)

\begin{tabular}{|c|c|c|c|c|c|c|}
\hline $\mathbf{N}^{\circ}$ & QUESTIONAMENTO (indicar o grau de importância) & CLASSE & $\mathbf{I}$ & II & III & IV \\
\hline \multirow{2}{*}{37} & Definição dos tipos de ensaio, amostragem e entidades para & \multirow{2}{*}{ B2 } & $0 \%$ & $0 \%$ & $46 \%$ & $54 \%$ \\
\hline & realização de ensaios diversos. & & \multicolumn{2}{|c|}{$0 \%$} & \multicolumn{2}{|c|}{$100 \%$} \\
\hline \multirow{2}{*}{38} & $\begin{array}{l}\text { Realização de ensaios de aderência em } 2 \text { panos, cada qual } \\
\text { composto por } 3 \text { pontos de arrancamento, em cada balancim, }\end{array}$ & \multirow{2}{*}{ SATISF } & $11 \%$ & $21 \%$ & $63 \%$ & $5 \%$ \\
\hline & $\begin{array}{l}\text { espalhados ao longo dos pavimentos ( } 1 \text { - mto pouco, } 2 \text { - pouco, } \\
3 \text { - satisfatório, } 4 \text { - excessivo). }\end{array}$ & & & & & \\
\hline \multirow[b]{2}{*}{39} & Importância e eficiência do acompanhamento dos prazos de & \multirow[b]{2}{*}{ B3 } & $0 \%$ & $0 \%$ & $69 \%$ & $31 \%$ \\
\hline & $\begin{array}{l}\text { execução da obra por meio da comparação entre os } \\
\text { cronogramas físico financeiro real e previsto. }\end{array}$ & & \multicolumn{2}{|c|}{$0 \%$} & \multicolumn{2}{|c|}{$100 \%$} \\
\hline \multirow{2}{*}{40} & Importância e eficiência de se condicionar o primeiro pagamento & \multirow{2}{*}{ B3 } & $0 \%$ & $13 \%$ & $54 \%$ & $33 \%$ \\
\hline & $\begin{array}{l}\text { (CEI) da obra, que envolve a ART, comprovação do CNPJ, projeto } \\
\text { e alvará de licença para construção aprovado pela prefeitura. }\end{array}$ & & \multicolumn{2}{|c|}{$23 \%$} & \multicolumn{2}{|c|}{$77 \%$} \\
\hline \multirow{2}{*}{41} & \multirow{2}{*}{$\begin{array}{l}\text { Importância e eficiência de se condicionar os diversos } \\
\text { pagamentos à apresentação, pela construtora, das guias de } \\
\text { quitação de recolhimento de FGTS e INSS. }\end{array}$} & \multirow{2}{*}{ B3 } & $0 \%$ & $17 \%$ & $58 \%$ & $25 \%$ \\
\hline & & & & & & \\
\hline \multirow{2}{*}{42} & \multirow{2}{*}{$\begin{array}{l}\text { Controle da correta execução dos elementos de segurança } \\
\text { (bandejas, aparatos, sinalização, telas etc.) }\end{array}$} & \multirow{2}{*}{ A } & $0 \%$ & $0 \%$ & $8 \%$ & $92 \%$ \\
\hline & & & \multicolumn{2}{|c|}{$0 \%$} & \multicolumn{2}{|c|}{$100 \%$} \\
\hline \multirow{2}{*}{43} & \multirow{2}{*}{$\begin{array}{l}\text { Exigência do uso de EPI's e elementos de idetificação por parte } \\
\text { dos operários. }\end{array}$} & \multirow{2}{*}{ A } & $0 \%$ & $0 \%$ & $12 \%$ & $88 \%$ \\
\hline & & & \multicolumn{2}{|c|}{$0 \%$} & \multicolumn{2}{|c|}{$100 \%$} \\
\hline \multirow{2}{*}{44} & \multirow{2}{*}{$\begin{array}{l}\text { Exigência de vistorias regulares semestrais da Delegacia Regional } \\
\text { do Trabalho (DRT). }\end{array}$} & \multirow{2}{*}{ C } & $0 \%$ & $27 \%$ & $58 \%$ & $15 \%$ \\
\hline & & & \multicolumn{2}{|c|}{$27 \%$} & \multicolumn{2}{|c|}{$73 \%$} \\
\hline
\end{tabular}


As questões técnicas se referem à definição dos ensaios para aceitação da execução dos serviços durante a obra, envolvendo tipos, amostragem e critérios para habilitação de entidades para a sua realização. A avaliação realizada indicou como importante esse tipo de definição, com grau médio de prioridade.

A quantidade de pontos para ensaio também foi bastante discutida entre os especialistas e, apesar do critério proposto de 2 panos de ensaio (cada qual com 3 pontos de arrancamento) em cada balancim, a discussão novamente indica a necessidade de uma avaliação específica para cada caso.

Dentre os aspectos operacionais, os itens que abordaram as questões relativas à segurança da obra, como o uso obrigatório dos Equipamentos de Proteção Individual (EPI's) e identificação pelos operários, e também o controle da correta execução das bandejas, balancins e telas foram considerados essenciais para o desenvolvimento adequado do serviço.

O acompanhamento dos prazos de execução da obra a partir dos cronogramas físicos previsto e real foi entendida como importante, porém com baixo grau de prioridade, assim como foi analisada a eficiência de se condicionar o primeiro pagamento da empresa executante à apresentação do Cadastro Específico do INSS (CEI) da obra.

Avaliação similar foi dada à proposta de se condicionar os pagamentos à apresentação pela empresa construtora das guias de recolhimento de FGTS e INSS, a fim de prevenir o condomínio de ações trabalhistas.

Por fim, a sugestão de exigência de vistorias regulares semestrais da Delegacia Regional do Trabalho (DRT) não foi avaliada como essencial para o bom andamento dos serviços. Na verdade essa exigência pode encontrar dificuldade de ser cumprida, pois está condicionada à disponibilidade da equipe da DRT para realizar as tais vistorias no período determinado.

A Tabela 22 apresenta os valores obtidos no estudo quanto à necessidade da contratação, pelo condomínio, de um gerenciador (empresa ou consultor) para coordenação das atividades de manutenção na fachada. As respostas indicam que o entendimento dos especialistas é de que se trata de uma atividade importante, com grau de prioridade considerado médio. 
Tabela 22 - Resultados obtidos no questionamento referente ao Grupo 7: Aspectos finais (I Irrelevante, II - Pouco relevante, III - Muito relevante, IV - Imprescindível)

\begin{tabular}{|c|c|c|c|c|c|c|}
\hline $\mathbf{N}^{\circ}$ & QUESTIONAMENTO (indicar o grau de importância) & CLASSE & $\mathbf{I}$ & II & III & IV \\
\hline \multirow{2}{*}{45} & \multirow{2}{*}{$\begin{array}{l}\text { Presença de uma gerenciador (contratado pelo condomínio) para } \\
\text { coordenação das ações junto ao condomínio e à construtora. }\end{array}$} & \multirow{2}{*}{ B2 } & $4 \%$ & $12 \%$ & $44 \%$ & $40 \%$ \\
\hline & & & \multicolumn{2}{|c|}{$16 \%$} & \multicolumn{2}{|c|}{$84 \%$} \\
\hline
\end{tabular}

A idéia proposta no trabalho é que o gerenciamento seja executado por profissional capacitado (empresa ou individual), contratado pelo condomínio para administrar as atividades de intervenção da fachada, que vão desde o diagnóstico das necessidades da edificação até o acompanhamento ou fiscalização dos serviços.

Os problemas tão comumente observados nesse tipo de obra decorrem, entre outros, da condução das atividades diretamente pelos envolvidos diretos, especialmente o condomínio (ou administradoras), cujo conhecimento técnico específico é, em geral, muito aquém do necessário.

Por conta desse desconhecimento os níveis de exigência durante a contratação e durante a execução da obra são baixos, deixando as empresas executantes livres para proposição de ações, muitas vezes, desnecessárias e onerosas. Importante se entender que esse serviço deve ser encarado como uma obra de engenharia que, além das naturais dificuldades inerentes a obras dessa natureza, têm ainda vários elementos complicadores, especialmente por se tratar de edificações habitadas ou em uso. 


\subsection{Discussões realizadas no estudo de caso}

Como elemento auxiliar da validação interna foi estudado o caso de um serviço de consultoria realizado em edifício residencial situado na cidade do Recife, Pernambuco, no qual foram adotados os procedimentos já anteriormente discutidos. Até o fechamento desse trabalho a obra ainda não havia sido concluída, de modo que algumas informações referentes ao final dos serviços não foram avaliadas.

No tocante à avaliação das necessidades do prédio, conforme descrito na Tabela 23, algumas das propostas apresentadas não puderam ser analisadas porque desde o momento da contratação da consultoria o condomínio já estava decidido a respeito do serviço que seria realizado. Com isso, discussões como as alternativas de solução técnica do problema e as pesquisas junto aos usuários para identificação de problemas não analisados na inspeção inicial não foram realizados.

Tabela 23 - Análise da avaliação das necessidades do prédio realizada no estudo de caso.

\begin{tabular}{l|l}
\hline \multicolumn{1}{c|}{ PROPOSTA APRESENTADA NA PESQUISA } & \multicolumn{1}{c}{ AVALIAÇÃo } \\
\hline $\begin{array}{l}\text { Utilização de metodologia padrão para o diagnóstico } \\
\text { das necessidades do prédio. }\end{array}$ & $\begin{array}{l}\text { Facilidade de elaboração e de análise comparativa } \\
\text { com casos de obras similares. }\end{array}$ \\
\hline Coleta de informações para investigação e diagnóstico & $\begin{array}{l}\text { Necessário e importante para se conhecer o histórico } \\
\text { do prédio e, especialmente, as manutenções } \\
\text { efetuadas. }\end{array}$ \\
\hline Realização de pesquisa junto aos usuários. & Não foi realizada. \\
\hline Ensaios de resistência de aderência à tração & $\begin{array}{l}\text { Essenciais para a definição das atividades, porém } \\
\text { realizados em quantidade insuficiente. }\end{array}$ \\
\hline Ensaios de percussão na fachada & Não foram executados. \\
\hline Apresentação de soluções técnicas alternativas para a \\
execução dos serviços.
\end{tabular}

De todo modo, os dados do prédio julgados importantes foram levantados para permitir adequada definição dos serviços necessários à execução da obra, porém não foi efetuada pesquisa junto aos usuários uma vez que não havia queixas de problemas nas áreas internas decorrentes da fachada. O principal elemento balizador nessa fase foi o ensaio de 
resistência de aderência à tração direta realizado no emboço, que permitiu avaliar a sua condição para receber novo revestimento.

Foram ensaiados 7 panos, cada qual composto por 6 pontos de arrancamento, totalizando 42 pontos. Como a área total de fachada é de $5.300 \mathrm{~m}^{2}$, a cada $750 \mathrm{~m}^{2}$ foi realizado um pano de ensaio, superior à proposta apresentada na pesquisa. Conforme já relatado, contudo, após o início dos serviços foi constatada a existência de trechos com deficiência na aderência entre o emboço e a base, obrigando a inclusão de aditivos contratuais.

Esse fato ressalta a importância da realização desses ensaios e reforça a idéia de que a quantidade e os locais para a sua realização devem ser discutidos para cada situação, e que quanto menor a amostragem utilizada maiores as possibilidades de surgirem serviços adicionais a serem realizados na obra.

Se a avaliação das necessidades foi pouco contemplada no estudo de caso, a análise e os critérios para seleção e contratação da empresa puderam ser bastante discutidos, gerando informações julgadas importantes relatadas a seguir e sumarizadas na Tabela 24.

Tabela 24 - Análise dos critérios para a seleção e contratação realizada no estudo de caso.

\begin{tabular}{|c|c|}
\hline PROPOSTA APRESENTADA NA PESQUISA & AVALIAÇÃO \\
\hline $\begin{array}{l}\text { Disponibilização de edital para as empresas } \\
\text { concorrentes. }\end{array}$ & $\begin{array}{l}\text { Facilidade de análise com as empresas, que avaliaram } \\
\text { o processo de concorrência como mais lícito. }\end{array}$ \\
\hline $\begin{array}{l}\text { Entrega de planilha de referência para que as } \\
\text { empresas preencham com os seus respectivos preços } \\
\text { e quantidades medidas no local. }\end{array}$ & $\begin{array}{l}\text { A partir das propostas foi elaborada planilha } \\
\text { comparativa que serviu de base para todas as demais } \\
\text { análises. }\end{array}$ \\
\hline $\begin{array}{l}\text { Explicitação de preços e quantidades em contrato } \\
\text { sujeitos a reajustes apenas em casos especiais. }\end{array}$ & $\begin{array}{l}\text { A proposta foi realizada, porém ainda não houve } \\
\text { oportunidade de avaliação. }\end{array}$ \\
\hline $\begin{array}{l}\text { Pagamento efetuado a partir das medições de serviço } \\
\text { executado, com valor máximo limitado em cronogrma } \\
\text { enviado pela construtora. }\end{array}$ & $\begin{array}{l}\text { As medições facilitam o acompanhamento do } \\
\text { cronograma físico da obra, e o valor máximo } \\
\text { estipulado evita surpresas ao condomínio. }\end{array}$ \\
\hline $\begin{array}{l}\text { Determinação de quantidades mínimas de pessoal e } \\
\text { equipamento. }\end{array}$ & $\begin{array}{l}\text { Foram tomados como importantes para evitar o atraso } \\
\text { no cumprimento dos prazos. }\end{array}$ \\
\hline
\end{tabular}




\begin{tabular}{l|l}
\hline $\begin{array}{l}\text { Presença sistemática de representante técnico da } \\
\text { empresa. }\end{array}$ & $\begin{array}{l}\text { Desde o início dos serviços a presença de um } \\
\text { encarregado de serviços se tem mostrado essencial } \\
\text { para o repasse de comandos junto aos operários. }\end{array}$ \\
\hline $\begin{array}{l}\text { Definição de sanções decorrentes de atrasos no } \\
\text { cumprimento dos prazos da obra. }\end{array}$ & Ainda não avaliados. \\
\hline $\begin{array}{l}\text { Apresentação de um documento final de entrega da } \\
\text { obra e manual de uso, operação e manutenção. }\end{array}$ & Ainda não avaliados. \\
\hline $\begin{array}{l}\text { Conferência da quitação de pagamentos referentes às } \\
\text { obrigações fiscais e trabalhistas pela construtora }\end{array}$ & $\begin{array}{l}\text { Vem garantindo ao condomínio o cumprimento das } \\
\text { obrigações da construtora. }\end{array}$ \\
\hline $\begin{array}{l}\text { Investigação prévia das áreas diversas e vizinhança } \\
\text { quanto à conservação. }\end{array}$ & $\begin{array}{l}\text { Foram efetuados registros das áreas sociais do prédio } \\
\text { (cobertura e área de lazer), cujos danos causados } \\
\text { ainda não foram avaliados. }\end{array}$ \\
\hline
\end{tabular}

O prazo para execução da obra, inclusive planejamento das frentes de serviço e definição de equipamento, foi discutido junto aos condôminos antes da elaboração do edital para adequar a realização dos serviços às condições ambientais e às necessidades do prédio.

Para o desenvolvimento do orçamento os quantitativos foram todos levantados no local, o que motivou a elaboração de uma planilha eletrônica com as medidas adotadas e separadas por trechos na fachada. Após o início da obra, surgiram dúvidas por parte da empresa executante a respeito de inclusão de trechos internos das varandas na área contemplada do serviço, imediatamente sanadas a partir da avaliação da planilha.

A definição dos preços adotados como referenciais nesse caso pode ser considerada como satisfatória, assim como as quantidades, a julgar pelas diferenças entre as propostas apresentadas pelas empresas e pela consultoria.

Para a seleção das empresas a disponibilização do documento formal (edital) para as empresas foi elogiada pelos concorrentes, que consideraram o processo de avaliação mais claro e inibidor à participação de empresas "aventureiras" ou pouco qualificadas. Por outro lado, as exigências acabaram restringindo o número de participantes, apesar do total de quatro propostas poder ser considerada uma quantidade satisfatória.

Todas as empresas apresentaram as suas propostas de preços a partir da planilha de referência encaminhada no edital, não havendo, em nenhum caso, sugestão de alteração aos itens de serviço indicados. Com isso pôde ser elaborada planilha comparativa das 
propostas apresentadas, item por item, e também uma curva $A B C$ de serviços classificada por preço. Tais planilhas foram utilizadas em todo o processo de concorrência, inclusive nas reuniões efetuadas com cada empresa para discussão das propostas.

Ainda no edital estava bem claramente definido que os preços e as quantidades de serviços não estariam passíveis de reajustes, a menos na ocorrência de algum tipo de alteração no projeto ou na conjuntura econômica.

Para o início dos serviços foi determinada uma pequena quantidade mínima de equipamentos e pessoal, o que foi atendido sem maiores dificuldades. Outra exigência foi quanto à presença sistemática do técnico da empresa na obra, que se foi tornando essencial especialmente pela existência de diferentes frentes de serviços simultâneas. Por conta disso, determinados comandos efetuados pela equipe de fiscalização da obra ou, eventualmente, pelos próprios condôminos, puderam ser efetuados para esse profissional.

As propostas referentes às atividades realizadas durante o acompanhamento técnico e operacional da obra vêm sendo colocadas em prática ao longo do andamento dos serviços (Tabela 25), de modo que as análises também não estão ainda concluídas.

Tabela 25 - Análise do acompanhamento dos serviços no estudo de caso.

\begin{tabular}{l|l}
\hline \multicolumn{1}{c|}{ PROPOSTA APRESENTADA NA PESQUISA } & \multicolumn{1}{c}{ AVALIAÇÃo } \\
\hline Realização de ensaios de aderência à tração direta. & $\begin{array}{l}\text { Os custos relativos aos ensaios com amostragem de 2 } \\
\text { pontos para cada } 1.000 \mathrm{~m}^{2} \text { representa apenas 1,5\% do } \\
\text { total da obra. }\end{array}$ \\
\hline Condicionar o primeiro pagamento à apresentação do & Essa exigência não foi cumprida. \\
CEI da obra & Esse controle tem sido efetuado de forma sistemática. \\
\hline Condicionar os diversos pagamentos à apresentação & As ações vêm sendo tomadas, e não há registro de \\
das guias de recolhimento de FGTS e INSS & acidentes até o presente momento. \\
\hline Controle da correta execução dos elementos de & Não foi efetuada. \\
\hline segurança (coletivos e individuais) & \\
\hline Exigência de vistorias regulares da DRT &
\end{tabular}

Quanto aos aspectos técnicos, até janeiro de 2008 foram realizados ensaios de resistência de aderência em 24 pontos espalhados pela fachada, no momento em que a área executada de cerâmica era em torno de $1.000 \mathrm{~m}^{2}$. Adotando essa amostragem para o 
restante da obra, para o total de $5.300 \mathrm{~m}^{2}$ de área seriam realizados cerca de 130 pontos de arrancamento. Como o custo previsto para realização dos ensaios é de $\mathrm{R} \$ 50,00$ para cada ponto ensaiado, o valor total referente ao controle tecnológico seria de $R \$ 6.500,00$, que representa apenas $1,5 \%$ do total da obra, valor aceitável para atividades dessa natureza.

Dentre os aspectos operacionais propostos destaca-se na obra a importância do acompanhamento dos prazos a partir da comparação entre o cronograma físico financeiro real e o previsto. A partir dessa análise tem sido possível ajustar quantidades de pessoal e equipamentos para o atendimento não apenas do prazo final da obra, mas também os prazos parciais para liberação dos diversos panos, evitando maiores transtornos em função da ocorrência de chuvas, por exemplo.

As questões relativas à segurança dos elementos de segurança coletivos (telas, aparatos, sinalização) e individuais dos operários têm sido acompanhadas, não sendo registrado nenhum tipo acidente, até o presente momento. A vistoria dos profissionais da DRT, porém, não foi exigida na obra.

Por fim, para o primeiro pagamento foi exigida a apresentação da documentação completa da construtora dos dados referentes à obra e à quitação das obrigações trabalhistas dos operários. 


\subsection{MÉTODO FINAL VALIDADO}

O objetivo dessa etapa do texto é apresentar de forma objetiva o método final considerado como cientificamente validado para a gestão de obras de manutenção em fachada, com base na discussão da validação interna de conteúdo realizada com os especialistas, complementada pelas análises efetuadas durante o estudo de caso.

As Figuras 9, 10, 11 e 12 indicam de maneira seqüenciada as atividades a serem seguidas para a gestão adequada do serviço, e as legendas indicam por meio de cores os níveis de relevância de cada uma das ações para se obter o sucesso.

Tratando o serviço desde o seu nascedouro, ou seja, desde o momento em que a consultoria é procurada para avaliar a situação da edificação, a ação inicial proposta, descrita na Figura 10, trata da apresentação aos condôminos das atividades principais necessárias para o bom andamento dos serviços.

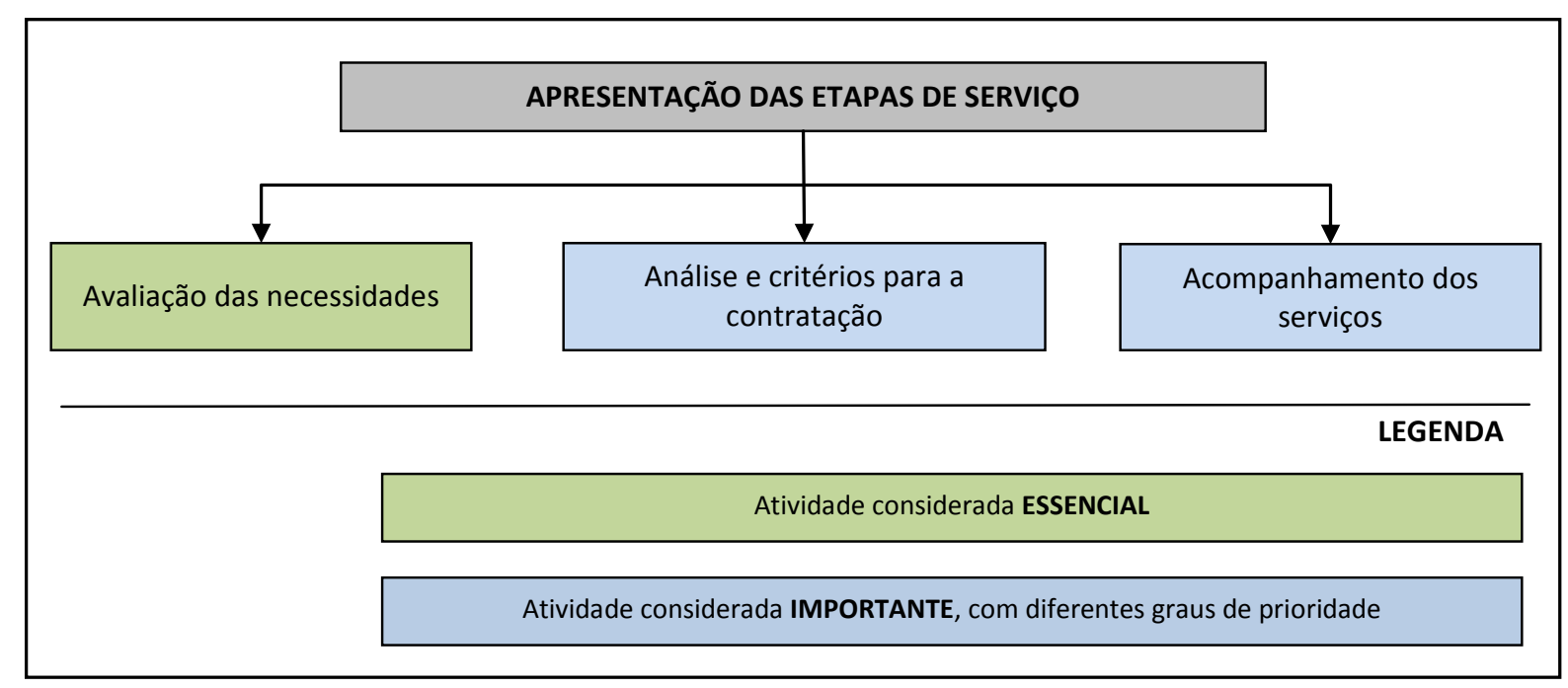

Figura 10 - Atividade inicial da gestão.

Apesar de essas atividades terem certa autonomia, facultando aos interessados a realização de apenas uma ou duas delas, o mais indicado é que as três ações sejam desenvolvidas pela consultoria a fim de evitar pontos de conflito que possam acontecer entre as mesmas. Cabe ressalvar que essa apresentação inicial deve ser efetuada da maneira mais clara e objetiva possível, uma vez que em muitas das situações os interessados são leigos no assunto e necessitam entender de forma simples o que se pretende realizar em cada uma das atividades, justificando a sua contratação. Conforme se pode observar, todas 
as ações descritas foram consideradas importantes pelos especialistas, em diferentes graus de prioridade.

A etapa de avaliação das necessidades do prédio, que em geral é aquela inicialmente solicitada pelos condôminos, possui as etapas de execução descritas na Figura 11 e também consideradas importantes na pesquisa. Nesse caso, a realização de pesquisas com os usuários é a única ação entendida pelos especialistas como importante apenas em situações especiais em que os problemas necessitem de uma investigação mais criteriosa e pontual.

Ponto determinante nessa etapa é a discussão dos ensaios necessários para a avaliação do caso. A idéia consensual extraída da pesquisa é que os ensaios de resistência de aderência à tração direta e de percussão podem ser considerados satisfatórios para a avaliação das necessidades do prédio, no entanto o consultor deve avaliar cada caso para decidir sobre a amostragem e o local de realização dos testes.

Ainda no tocante aos ensaios é preciso também entender que, especialmente nos ensaios de aderência à tração, a sua execução pode ser dispensada, ou ter a quantidade reduzida, nos casos em que a intervenção na edificação apresentar caráter preventivo e não corretivo. 


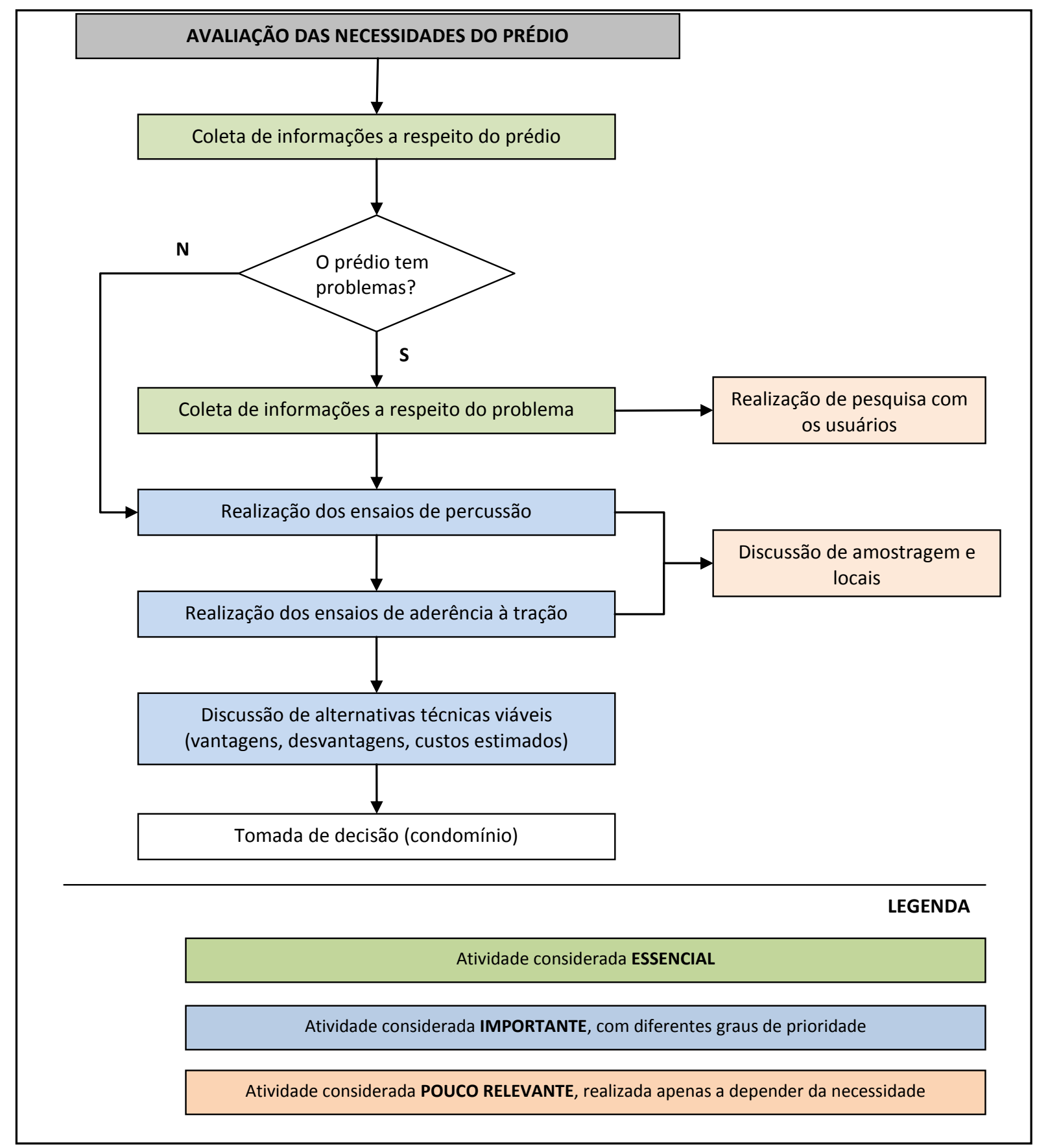

Figura 11 - Descrição das atividades propostas para a avaliação das necessidades do prédio.

O objetivo principal dessa etapa de avaliação das necessidades do prédio é fornecer aos condôminos informações suficientes que permitam a tomada de decisão a respeito da intervenção a ser realizada. Essa etapa, portanto, não contempla discussões detalhadas sobre o processo executivo, especificações de materiais, e sim avaliações apenas estimadas de custos, prazos, vantagens e dificuldades envolvidas durante a realização da obra. Essa consideração deve ser informada ao condomínio desde a apresentação das etapas propostas, evitando que sejam criadas expectativas inválidas. 
A contratação efetiva dos serviços, que envolve análises e critérios para seleção, trata das considerações que, caso bem definidas e explicitadas, poderão permitir adequado desenvolvimento da obra e acompanhamento dos serviços. Por essa razão a maioria das questões discutidas na validação interna de conteúdo contempla ações relacionadas com o tema, e os seus passos estão sumarizados na Figura 12.

O ponto de partida para a contratação da empresa para execução dos serviços é a elaboração de um documento formal (edital) no qual são apresentadas questões relativas à execução dos serviços e a aspectos financeiros, técnicos e operacionais, fundamentais para o adequado andamento da obra.

Para o projeto executivo da obra é importante a discussão dos prazos envolvidos e suas repercussões, que servirá de base para a definição dos procedimentos para produção, juntamente com as prescrições estabelecidas no projeto de arquitetura da obra. A partir desses dados parte-se para o cuidadoso levantamento dos quantitativos dos serviços e para a coleta de preços no mercado, que culminarão com a elaboração da planilha orçamentária básica de referência. 


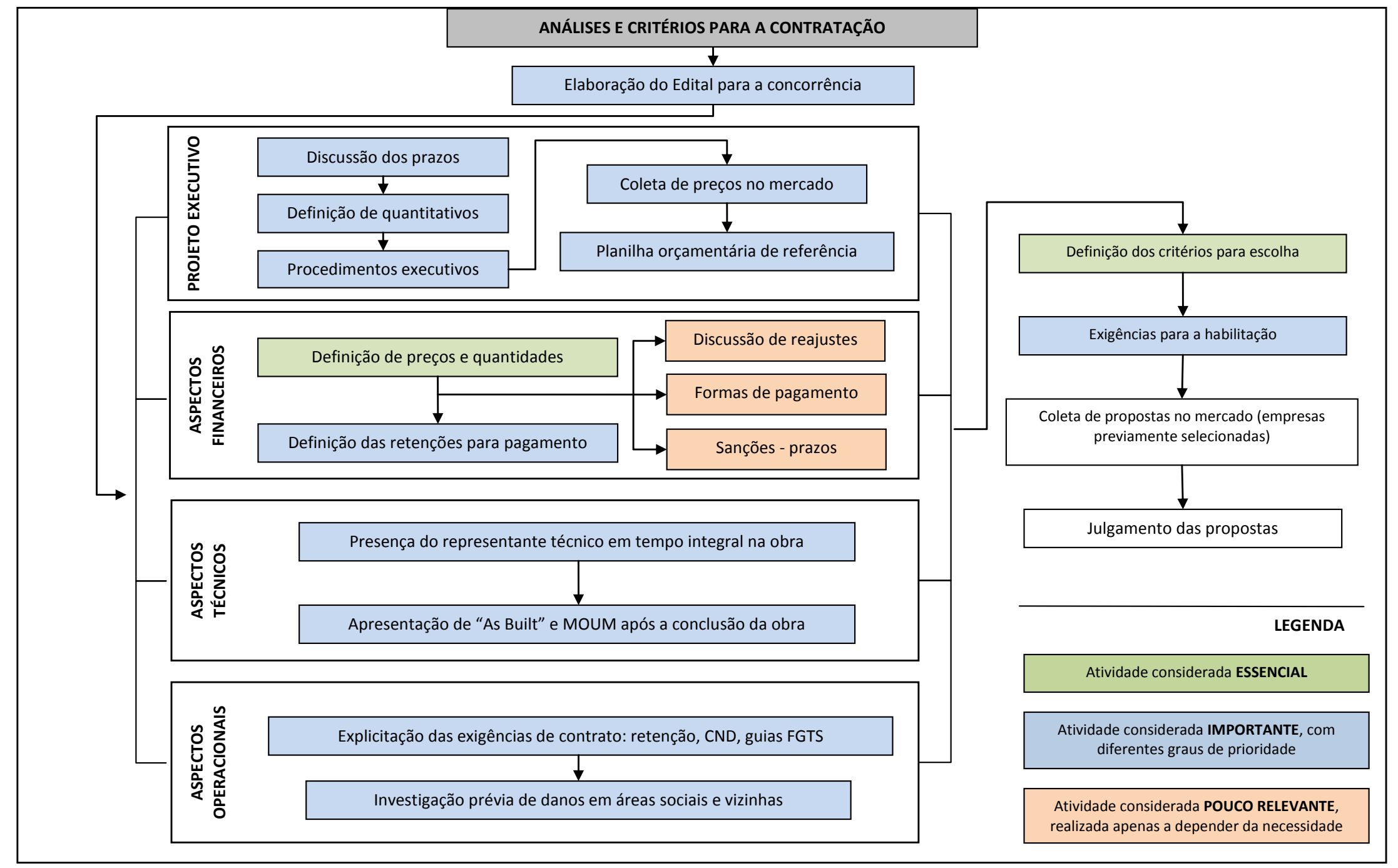

Figura 12 - Descrição das atividades propostas para a contratação da empresa executante. 
A planilha orçamentária tem o objetivo de orientar os condôminos a respeito dos custos efetivos dos serviços contratados e, uma vez que faz parte do edital, serve como referência para elaboração das suas propostas. Com isso, a análise comparativa de preços propostos pelas empresas se torna facilitada.

A depender de cada situação a planilha encaminhada às empresas pode conter todas as informações do orçamento (itens de serviço, quantidades e preços de referência), ou apenas alguns deles. As considerações envolvidas em cada uma das alternativas são:

- Inclusão apenas dos itens de serviço: obriga as empresas concorrentes a medir as quantidades no local, servindo, com isso, como uma conferência do levantamento prévio efetuado pela consultoria. Por outro lado, é mais uma variável, além do preço, que irá contribuir para a dispersão das propostas;

- Inclusão dos itens de serviços e das quantidades: nesse caso a empresa preenche apenas a coluna dos preços propostos, o que facilita as comparações, entretanto abre a possibilidade de contestação posterior das quantidades previstas em contrato;

- Inclusão de todas as informações: serve para os casos em que o valor máximo a ser pago na obra não pode ser extrapolado, e acaba funcionando como uma espécie de leilão. Privilegia os casos em que o critério de escolha se dará mais pelo preço ofertado do que pela qualificação da empresa.

Em qualquer das situações é facultado à empresa concorrente a sugestão de inclusão ou retirada de quaisquer dos itens apresentados, o que, porém, deve ser apresentado à parte para evitar transtornos durante a avaliação comparativa.

Dentre as questões financeiras relativas aos pagamentos, foi entendido como essencial na pesquisa a definição em contrato dos preços, quantidades, sanções e multas dos serviços. Outro aspecto considerado importante foi a determinação das retenções dos valores medidos nos pagamentos dos serviços, quitadas de forma paulatina após a conclusão da obra, com o objetivo de custear eventuais problemas surgidos ao longo das atividades e não ressarcidos pela empresa executante.

Já a definição de reajustes de preços e quantidades em contrato foi entendida como uma determinação de difícil controle pelos envolvidos, devido não apenas às oscilações 
econômicas do país, mas também à imprevisibilidade natural desse tipo de obra, onde problemas de ordem técnica e operacional, e não identificados numa análise inicial, podem surgir ao longo dos serviços.

O objetivo dessa exigência é evitar o surgimento excessivo de aditivos contratuais à obra, cujos transtornos junto aos envolvidos são grandes, porém é preciso deixar claro que, apesar de todas as ações tomadas desde a análise das necessidades para a intervenção serem também para reduzir esses problemas, há ainda a possibilidade da sua ocorrência, certamente, porém, em menor escala.

A discussão junto ao condomínio a respeito das formas de pagamento foi avaliada como de menor importância na pesquisa, não sendo considerada essencial para o sucesso da atividade de gestão.

Outra ação considerada menos importante na pesquisa foi a previsão em contrato de sanções pelo descumprimento do prazo de conclusão da obra pela empresa executante. A julgar pelos casos apresentados no capítulo 3, esse é um problema recorrente em obras dessa natureza, de modo que a sua implementação se torna especialmente importante nas situações em que a empresa executante apresente histórico de problemas dessa natureza em outras obras.

Com relação aos aspectos técnicos o entendimento quanto à presença sistemática de um técnico da empresa em tempo integral foi de que essa exigência é importante, em especial se esse representante for um encarregado ou mestre de obra. Já a necessidade de um engenheiro em tempo integral deve ser analisada conforme o porte dos serviços, uma vez que irá onerar os custos da obra.

Ao final dos serviços foi discutida a explicitação em contrato da apresentação pela empresa executante de um manual de operação, uso e manutenção (MOUM) da edificação, bem como de um documento formal ("As Built"), ambos considerados importantes em alto grau de prioridade.

As tratativas relativas aos aspectos operacionais indicaram como importante a exigência em contrato de que os valores correspondentes às obrigações fiscais e trabalhistas de responsabilidade da empresa executante possam ser retidos nas próprias medições de pagamento, caso o condomínio assim deseje, o mesmo no que se refere à apresentação das 
guias de recolhimento dos referidos pagamentos ao longo da obra, e da Certidão Negativa de Débitos (CND). São ações que buscam preservar o condomínio do surgimento de ações trabalhistas durante e após a conclusão da obra, ficando o seu efetivo cumprimento a cargo do contratante, por conta das dificuldades operacionais relacionadas.

A exigência da investigação do estado de conservação das áreas sociais do prédio e da vizinhança, inclusive registro e documentação, foi também avaliada como importante pelos especialistas, a fim de evitar solicitações posteriores indevidas ao condomínio e à própria empresa executante.

Um aspecto considerado essencial é a definição prévia dos critérios adotados para a escolha da empresa executante, explicitada no edital, esclarecendo que serão levados em conta o preço e a qualificação das concorrentes, e que o condomínio tem livre arbítrio para efetuar essa decisão. A fim de permitir uma adequada análise, foi avaliada também como importante a inclusão de exigências para a habilitação da empresa, como a comprovação de serviços similares e capital social compatível com o porte da obra.

Concluído o edital, o mesmo permanece disponível às empresas concorrentes, convidadas a partir de indicações, durante período de tempo julgado suficiente para uma correta avaliação dos serviços e elaboração da proposta.

Após a conferência das exigências para habilitação, as propostas podem ser compiladas pela consultoria em planilha eletrônica para avaliação. Nessa etapa podem ser necessárias reuniões de esclarecimento junto às empresas, ocasião em que todos os envolvidos (condomínio, consultoria e empresa proponente) têm a oportunidade de discutir as considerações apresentadas e, se for julgado importante, efetuar ajustes necessários para permitir a melhor escolha da proposta vencedora.

$\mathrm{Na}$ etapa de acompanhamento dos serviços, todas as ações propostas foram entendidas como importantes pelos especialistas, conforme se observa na Figura 13, exceção feita à exigência de visitas regulares pela Delegacia Regional do Trabalho (DRT), que poderia acabar se tornando um problema, uma vez que a sua execução é dependente da efetiva disponibilidade desses profissionais.

Dentre as questões técnicas se destaca a discussão e avaliação dos resultados obtidos nos ensaios diversos propostos, que tratam da qualidade tanto dos materiais como do 
processo produtivo. Assim como ocorreu na discussão a respeito dos estudos iniciais de avaliação das necessidades do prédio, também nessa etapa a amostragem e os locais dos ensaios devem ser definidos a partir das condições particulares encontradas em cada obra.

Também no tocante ao controle da qualidade dos materiais e serviços, cabe reforçar a idéia de se proceder ao registro dos ensaios realizados ao longo da obra, e mesmo daqueles efetuados pelos próprios fornecedores dos materiais, para que sirvam como uma comprovação dos cuidados tomados durante a execução dos serviços.

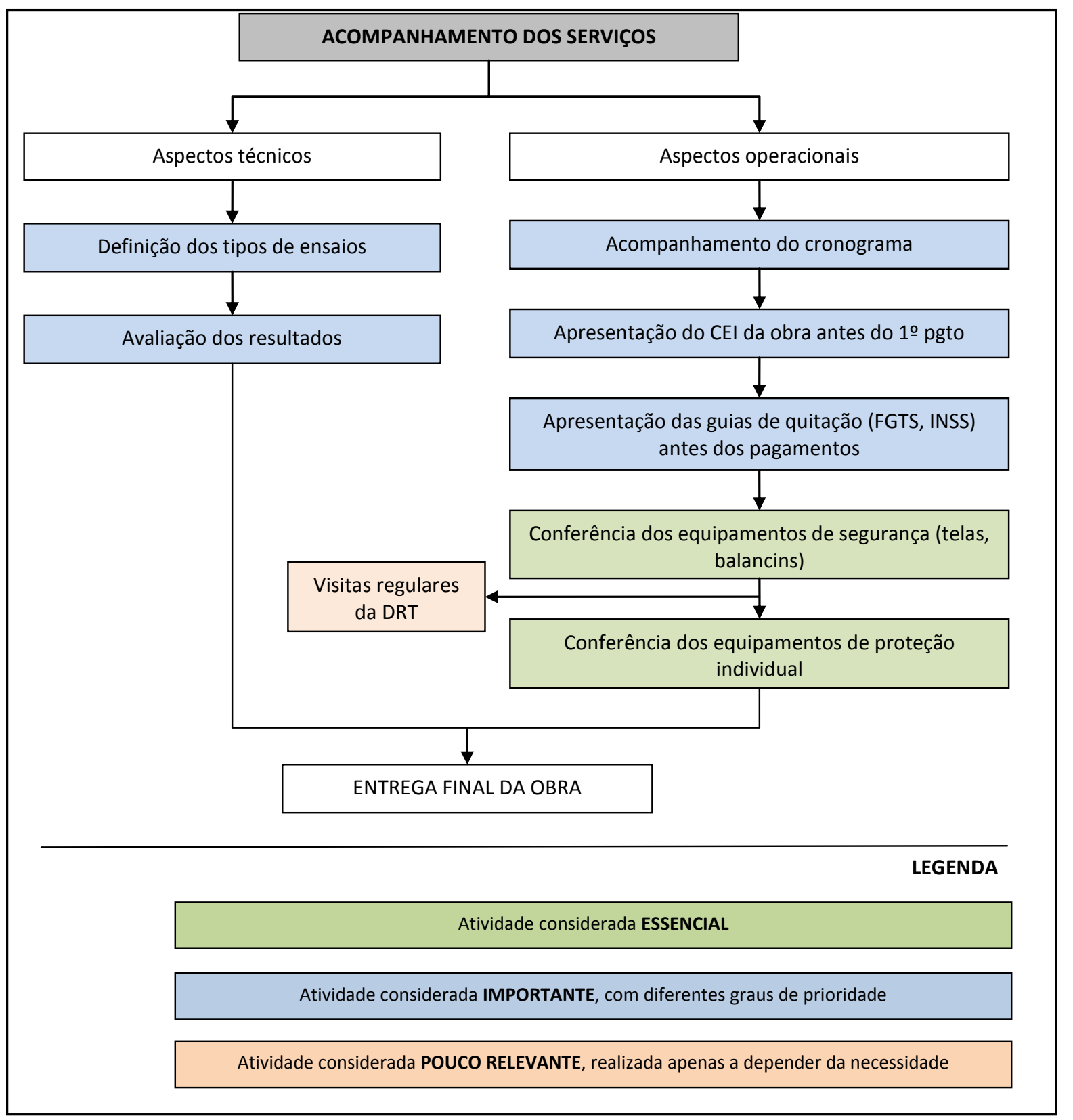

Figura 13 - Descrição das atividades propostas para o acompanhamento dos serviços. 
As questões operacionais envolvem ações que não estão ligadas diretamente com o processo produtivo, mas têm influência significativa no sucesso da intervenção como um todo. O acompanhamento do cronograma físico previsto com o executado, por exemplo, permite o ajuste do andamento dos serviços, orientando quanto à necessidade de inclusão de pessoal ou equipamentos.

As exigências apresentadas em contrato referentes à habilitação das empresas para execução do serviço, com o objetivo de resguardar os interesses do condomínio de um problema jurídico futuro, devem ser comprovadamente atendidas antes da liberação dos pagamentos. Dentre as exigências se destacam a apresentação do CEI (Cadastro Específico do INSS) da obra e das guias de quitação de recolhimento de FGTS e INSS.

Por fim, todas as propostas apresentadas que tratam dos aspectos de segurança dos serviços foram entendidas pelos especialistas como essenciais para a gestão da obra. As ações mais importantes são a conferência da correta execução dos elementos de segurança (balancins, aparatos, telas de proteção) e a exigência rigorosa quanto ao uso dos equipamentos de proteção individual (EPI) e identificação por parte dos operários. 


\section{CONCLUSÃO}

Neste capítulo são apresentadas de forma condensada as considerações julgadas mais importantes a respeito do trabalho com base nos objetivos definidos e nos resultados obtidos ao longo do estudo.

O trabalho teve como objetivo a proposição de um método para gestão de obras de manutenção em fachada a fim de resultar num adequado desempenho técnico e operacional. Assim, para definição das atividades propostas no método foram tomados como referência a experiência em casos de obras dessa natureza não orientados, acompanhados pelo autor, e a abordagem teórica desenvolvida a partir da literatura específica.

Além da proposição do método estava previsto no objetivo a comprovação da sua adequação sob os aspectos técnicos e operacionais, o que foi efetuado por meio de uma validação interna de conteúdo realizada junto a especialistas da área. Como atividade complementar, em paralelo à validação interna foi efetuada avaliação da efetiva aplicabilidade do método a partir do estudo de caso em obra onde as propostas apresentadas inicialmente foram adotadas.

Com base no exposto, têm-se as seguintes considerações específicas:

\subsection{Quanto à importância do tema}

O estudo de técnicas para a gestão de obras de manutenção em edificações de múltiplos pavimentos vem se tornando cada vez mais necessário, em especial porque esses prédios estão envelhecendo e, associada à incipiente cultura de manutenção existente no Brasil e à sua concepção voltada apenas para o atendimento às solicitações mecânicas, e não à durabilidade, a tendência é que a demanda por esse tipo de serviço cresça em ritmo acelerado.

Assim, a razão para o estudo específico dos revestimentos de fachada decorreu de três fatores: a falência desses elementos, em geral, ocorre antes do que da própria estrutura, indicando imperativa necessidade de intervenção; a maior susceptibilidade à ocorrência de problemas por conta do crescente arrojo nas concepções estruturais e arquitetônicas das edificações; e a complexidade envolvida nesse tipo de obra de 
manutenção pelo fato dos principais agentes envolvidos (contratante - condomínio, contratado - construtor) apresentarem diferentes níveis de conhecimento e interesses.

Concluímos que a aplicação dos conceitos discutidos nessa pesquisa contribuirá para o estudo da "Patologia das Construções" como ciência, especialmente a abordagem relativa às tratativas entre o corpo técnico envolvido e os usuários do imóvel, dada a pequena quantidade de pesquisas específicas no Brasil com esse enfoque.

\subsection{Quanto à abordagem conceitual}

Existe uma grande dificuldade de se encontrar estudos específicos sobre o tema, especialmente por se tratar de um problema multidisciplinar. As dificuldades residem no fato de que estudos dessa natureza necessitam de avaliações práticas amparadas por uma consolidada abordagem acadêmica.

Na construção civil há o equivocado costume de se pautar decisões conceituais a partir da avaliação de erros e acertos obtidos em campo, como se a prática conduzisse a teoria, e não o contrário.

Por conta disso, ao longo do estudo buscou-se uma constante associação entre a teoria e a prática. O referencial teórico, base para o desenvolvimento do método de gestão, foi precedido pela discussão de estudos de caso reais acompanhados pelo autor nos quais foram apresentados fatores de sucesso e de falhas. Ao final, simultaneamente ao estudo de validação do conteúdo do método foi realizada uma avaliação da sua aplicabilidade em uma situação prática real, sem a pretensão de se buscar uma validação externa, possível, apenas, a partir de um estudo de caso adotando as propostas apresentadas.

Ao final do trabalho concluímos ser evidente a importância do estudo da adequação das ações realizadas em campo legitimado a partir do conhecimento teórico obtido na literatura, possibilitando, com isso, uma leitura acadêmica criteriosa a respeito das situações práticas impostas e necessárias em todo estudo relacionado com obras de construção civil. 


\subsection{Quanto ao método de gestão proposto}

Uma das grandes dificuldades encontradas durante a elaboração das atividades propostas foi a análise do nível de aprofundamento necessário das questões técnicas envolvidas na obra sem que se perdesse o foco na sua gestão, objetivo do estudo.

Conforme já comentado, além da abordagem teórica, a discussão dos problemas enfrentados em obras dessa natureza acompanhadas pelo autor sem a adoção de um método de gestão orientado, descritas na fase exploratória (Capítulo 3), foi essencial para entendimento dos anseios e necessidades das partes envolvidas.

A principal conclusão a que se chegou com o estudo é que o trabalho deve ser conduzido a partir das seguintes premissas:

- A gestão deve ser realizada por uma consultoria independente, que atuará como conciliador dos interesses conflitantes entre contratante e contratado;

- A gestão envolve três atividades essenciais: a avaliação das necessidades do prédio; a definição de critérios para a seleção e a contratação da empresa executante; e o acompanhamento técnico e operacional dos serviços.

As três atividades são complementares, e devem ser todas executadas para reduzir a possibilidade de insucesso na intervenção. Cada uma das atividades pode ser exercida por profissionais diferentes, cabendo à gerenciadora, nesse caso, uma função de supervisão, ou a própria gerenciadora pode executá-las, a fim de evitar o surgimento de eventuais lacunas entre os serviços. Para o condomínio, em geral a segunda alternativa é tida como mais interessante, uma vez que as dificuldades surgidas poderão ser discutidas em foro único.

A etapa de avaliação das necessidades é essencialmente técnica, envolvendo questões de caráter executivo que necessitam de um forte conhecimento para embasar as alternativas de intervenção indicadas para o caso. Por isso o presente estudo recomenda que essa atividade seja realizada por profissional com comprovada habilitação e experiência.

Já a etapa de contratação possui um forte cunho gerencial, e é essencial para assegurar o controle efetivo das ações durante a execução da obra. Na discussão efetuada ao longo do trabalho pôde-se concluir que muitas das considerações apresentadas em 
contrato podem até nem ser plenamente exigidas durante o acompanhamento, mas devem estar explicitadas servindo como um fator de segurança para eventual necessidade.

A etapa de acompanhamento é a mais prolongada, e é onde ocorrem os conflitos de interesses, razão pela qual é bastante dependente de um adequado acordo firmado durante a elaboração do contrato.

É importante ressaltar que, além das proposições apresentadas, podem existir várias outras atividades recomendadas para a adequada gestão dessas obras e que não foram apresentadas no texto. A inclusão de outras atividades, ou a exclusão de algumas descritas no presente estudo, deverá ser avaliada em conformidade com o porte a as necessidades de cada caso.

\subsection{Quanto ao método de validação}

O método de validação adotado, Método Delphi, apesar de não ser específico para esse tipo de estudo, com as devidas adaptações mostrou-se eficiente para se conhecer o entendimento das pessoas sobre o tema.

O questionário encaminhado aos especialistas foi elaborado indicando ações julgadas relevantes, facultando aos respondentes indicarem níveis de importância de cada uma. Importante destacar que nenhuma das proposições encaminhadas foi entendida pelos especialistas como irrelevante para a atividade de gestão estudada, ocorrendo apenas uma separação por níveis de prioridade, o que concorre para a adequação plena das ações propostas de gestão.

Destaca-se como limitação do método a quantidade de participantes habilitados e dispostos a participar da pesquisa. No presente trabalho, o número final de 28 (vinte e oito) especialistas pode ser considerado significativo, entretanto foi necessário o envio de 72 (setenta e dois) convites para a obtenção das 28 respostas válidas no final, o que corresponde apenas a $39 \%$ das consultas.

O perfil dos respondentes indicou a participação de acadêmicos, em sua maioria, e de profissionais atuantes em empresas de consultoria. O local de atuação contemplou as quatro principais regiões do país (sudeste, sul, nordeste e centro oeste), o que enfatiza a abrangência da pesquisa. 
O prazo total necessário foi relativamente pequeno, de apenas 9 (nove) meses corridos, desde a preparação do questionário até o recebimento da última resposta, suficiente para a posterior análise dos dados e desenvolvimento da pesquisa.

Concluímos que a técnica de pesquisa realizada com a utilização do método Delphi, com as devidas e naturais adaptações, permitiu a obtenção das informações necessárias para a correta validação do método de gestão proposto.

Um dos fatores considerados essenciais para o sucesso do método foi o estímulo à participação das pessoas, cujo ritmo de trabalho, muitas vezes acelerado, não favorece o envolvimento nesse tipo de estudo. Por isso, a opção pela preparação de uma página na internet mostrou-se bastante eficiente, proporcionado ao especialista maior segurança das informações e facilidade para preenchimento paulatino dos questionamentos apresentados.

Outro aspecto julgado importante para o estímulo à participação foi sempre o envio de e-mails individuais para cada um dos convidados, com identificação do destinatário no assunto da mensagem, favorecendo a aproximação entre o pesquisador e o respondente.

\subsection{Quanto à aplicabilidade do método em campo}

A aplicação do método proposto na pesquisa em um estudo de caso, mesmo que ainda não validado pelos especialistas, teve como principal objetivo verificar as dificuldades e facilidades envolvidas com a adoção das práticas indicadas, comparando também com os casos discutidos anteriormente na fase exploratória.

Apesar da obra ainda não ter sido concluída até a conclusão do presente estudo (apenas cerca de $35 \%$ do total), podemos concluir que as ações efetuadas têm servido para atenuar vários problemas ao longo do andamento dos serviços (como a discussão de quantitativos adicionais e exigências de segurança, por exemplo), além de ter tido avaliação considerada positiva por parte do condomínio contratante e das empresas concorrentes.

Para que o método de gestão apresentado nesse estudo seja mais bem discutido pela comunidade científica pretende-se publicar artigos científicos em congressos nacionais, tanto na área de gestão de processos na construção como também nas áreas de engenharia da produção e administração. 
Recomendamos que os dados e informações dessa pesquisa sejam aplicados como apoio à atualização da NBR 5674 (ABNT, 1999), que trata da manutenção das edificações, uma vez que poderia indicar procedimentos validados de forma científica para auxiliar na execução desses serviços.

Como envolve assuntos diretamente ligados à administração condominial, pretendese também discutir o estudo em palestras de divulgação junto aos Secovi's regionais, que representam condomínios e empresas de administração, assim como em cursos e publicação de artigos em revistas especializadas.

Cabe também destacar que esse serviço de gestão de obras de manutenção em fachada pode ser oferecido por empresas especializadas a construtoras, a fim de coordenar as intervenções periódicas propostas no manual de uso, operação e manutenção entregue ao condomínio, especialmente caso não seja do interesse das mesmas executar tais serviços.

A prestação desse serviço também pode ser ampliada para os casos em que as construtoras são procuradas para a solução de problemas surgidos nas suas obras (dentro ou fora do prazo de garantia). É interessante para a construtora, pois lhe assegura que a obra será conduzida de forma concisa e profissional, sem interesses outros, e para o condomínio, que terá uma intervenção avaliada por profissionais especialistas, e indicados pelo construtor.

Nesses termos, a tese defendida na presente pesquisa é que o método de gestão proposto para o desenvolvimento de atividades de manutenção em revestimentos de fachadas é comprovado cientificamente como adequado ao desempenho técnico e operacional da obra.

\subsection{Recomendações para estudos futuros}

Para que se possa assegurar a continuidade das pesquisas na área, são apresentadas a seguir indicações de estudos correlatos ao tema apresentado no presente trabalho:

- Complementação do estudo com aplicação das propostas validadas em um estudo de caso (validação externa). 
- Elaboração de um método geral de gestão para os diferentes tipos de problema em obras (estrutura de concreto, fundações, instalações prediais);

- Adaptação do estudo realizado para obras públicas, com os devidos ajustes às exigências desses órgãos;

Trata-se de um ramo da construção em plena expansão, principalmente porque os prédios estão envelhecendo, e cada vez mais será necessário o conhecimento de técnicas de comprovada eficiência para resolução desses problemas. E para isso o estudo foi desenvolvido.

Finalmente, consideramos que o trabalho realizado representa um avanço na área de Tecnologia e Gestão de edifícios, contribuindo para prevenir insucessos nas atividades de manutenção em fachadas, área pouco visada na bibliografia nacional, mas de importância crescente em face dos altos custos envolvidos. 


\section{REFERÊNCIAS BIBLIOGRÁFICAS}

AGUILERA, Camila Garcia; NOVAES, Celso Carlos. Manual do usuário de edifícios - uso, operação e manutenção. In: X Encontro Nacional de Tecnologia do Ambiente Construído ENTAC. São Paulo, 2004.

ALANI, Amir; PETERSEN, Andrew, CHAPMAN, Keith. Applications of a developed quantitative model in building repair and maintenance - case study. Facilities. v.19, n.5/6, 2001. p215-221.

ANDOLFATO, Rodrigo Piernas; CAMACHO, Jefferson Sidney; MAURÍCIO, Rodrigo Menossi. Estudo comparativo dos processos de análise de estabilidade global de edifícios. In: 45o Congresso Brasileiro do Concreto. IBRACON. Vitória, 2003.

ANTUNES, Helena Maria Cunha do Carmo; IWAMOTO, Roberto Kunihiro. A importância da consideração da interação solo-estrutura para edifícios de múltiplos andares. In: 42으 Congresso Brasileiro do Concreto. IBRACON. Fortaleza, 2000.

APPLETON, João; BAIÃO, Manuel. Inspecção de edifícios para diagnóstico do seu estado patológico. In: 2o Encontro Sobre Conservação e Reabilitação de Edifícios - ENCORE. LNEC. Lisboa, 1994. p313-318.

ARANHA, P.M.S. Contribuição ao estudo das manifestações patológicas em estruturas de concreto armado na região amazônica. Porto Alegre, 1994. Dissertação (Mestrado) Universidade Federal do Rio Grande do Sul.

ASSOCIAÇÃO BRASILEIRA DE NORMAS TÉCNICAS - ABNT. Argamassa colante industrializada para assentamento de placas cerâmicas - requisitos - NBR 14081. Rio de Janeiro, 2004.

A.R. - Argamassa à base de cimento Portland para rejuntamento de placas cerâmicas - requisitos e métodos de ensaio - NBR 14992. Rio de Janeiro, 2003a.

Cal hidratada para argamassas - requisitos - NBR 7175. Rio de Janeiro, 2003b.

. Execução de revestimentos de paredes e tetos de argamassas inorgânicas procedimento - NBR 7200. Rio de Janeiro, 1998a.

Manual de operação, uso e manutenção das edificações - conteúdo e recomendações para elaboração e apresentação - NBR 14037. Rio de Janeiro, 1998b.

Manutenção de edificações - procedimento - NBR 5674. Rio de Janeiro, 1999.

. Placas cerâmicas para revestimento - classificação - NBR 13817. Rio de Janeiro, 1997.

$2003 c$.

Projeto de estruturas de concreto - procedimento - NBR 6118. Rio de Janeiro,

Revestimento de paredes e tetos de argamassa inorgânica - NBR 13530. Rio de Janeiro, 1995a.

Revestimento de paredes e tetos de argamassa inorgânica - Determinação da resistência de aderência à tração - NBR 13528. Rio de Janeiro, 1995b.

Revestimento de paredes e tetos de argamassa inorgânica - Especificação - NBR 13749. Rio de Janeiro, 1996a. 
Revestimento de paredes externas e fachadas com placas cerâmicas e com utilização de argamassa colante - procedimento - NBR 13755. Rio de Janeiro, 1996b.

ATTALLA, Mohamed; HEGAZY, Tarek. Success of reconstruction projects: a statistical investigation. Cost Engineering. v.45, n.3, 2003. p25-31.

; HEGAZY, Tarek; ELBELTAGI, Emad. In-house delivery of multiple-small reconstruction projects. Journal of Management in Engineering. v.20, n.1, 2004. p25-31.

BARRIENTOS, Maria Izabel; QUALHARINI, Eduardo. Retrofit de construções: metodologia de avaliação. In: X Encontro Nacional de Tecnologia do Ambiente Construído - ENTAC. São Paulo, 2004.

BARROS, Mércia Maria Bottura Semensato. Metodologia para implantação de tecnologias construtivas racionalizadas na produção de edifícios. São Paulo, 1996. Tese (Doutorado) Escola Politécnica da Universidade de São Paulo.

BERNARDES, Maurício Moreira e Silva; SCHMITT, Carin Maria; CARRILHO, Diego. Indicadores para análise do processo de planejamento da produção de empresas construtoras. In: VII Encontro Nacional de Tecnologia do Ambiente Construído - ENTAC. Florianópolis, 1998. p559-567.

BRE. BUILDING RESEARCH ESTABLISHMENT. Building façade maintenance: legal liability and damage limitation. England: BRE, 2001. Disponível em: <http://www.bre.co.uk/pdf/facademaintenance.pdf>. Acesso em: 17 ago. 2007.

BRESSIANI, Lúcia; HEINECK, Luiz Fernando. Recolhimento de INSS em obras de construção civil - um comparativo entre os consumos teóricos de mão-de-obra expressos na NBR 12721 e o consumo real em uma obra. In: $X$ Encontro Nacional de Tecnologia do Ambiente Construído - ENTAC. São Paulo, 2004.

CAMPANTE, Edmílson Freitas. Metodologia de diagnóstico, recuperação e prevenção de manifestações patológicas em revestimentos cerâmicos de fachada. São Paulo, 2001. Tese (Doutorado) - Escola Politécnica da Universidade de São Paulo.

CARASEK, Helena. Aderência de argamassas à base de cimento Portland a substratos porosos - avaliação dos fatores intervenientes e contribuição ao estudo do mecanismo da ligação. São Paulo, 1996. Tese (Doutorado) - Escola Politécnica da Universidade de São Paulo.

CARDOSO, Luiz Reynaldo de Azevedo; ABIKO, Alex Kenya; HAGA, Heitor César Riogi; INOUYE, Kelly Paiva; GONÇALVES, Orestes Marraccini. Prospecção de futuro e Método Delphi: uma aplicação para a cadeia produtiva da construção habitacional. Ambiente Construído. v.5, n.3, 2005. p63-78.

LORDSLEEM JR., Alberto Casado; NEVES, Maria Luiza Rodrigues. Renovação de revestimentos de fachada: materiais, equipamentos e técnicas de execução. Relatório de pesquisa de iniciação científica. Universidade de Pernambuco, Recife, 2007 (não publicado).

CASIMIR, Crispin. Testing, evaluation and diagnostics. In: International Conference On Building Envelope Systems And Technology. Singapore, 1994. p79-84.

COSTA, Sérgio Francisco da. Método científico - os caminhos da investigação. São Paulo, Ed. Harbra, 2001. 100p. 
COSTA E SILVA, Angelo Just da. Descolamentos nos revestimentos cerâmicos de fachada na cidade do Recife. São Paulo, 2001. Dissertação (Mestrado) - Escola Politécnica da Universidade de São Paulo.

CHRISTODOULOU, Symeon; GRIFFIS, F.H.(Bud); BARRET, Lisa; OKUNGBOWA, M. Qualifications-Based selection of professional A/E services. Journal of Management in Engineering. v.20, n.2, 2004. p34-41.

CUNHA JR, Gilberto José Carneiro; HOLANDA, Marcos Antônio Arruda Guerra; C. FILHO, Arnaldo Cardim; COSTA E SILVA, Angelo Just. Avaliação comparativa da resistência à tração de argamassas utilizando bases de concreto com diferentes níveis de absorção e porosidade. In: 48 Congresso Brasileiro do Concreto. IBRACON. Rio de Janeiro, 2006.

DORFMAN, Gabriel; PETRUCCI, Helena. Recomendações para o projeto de fachadas com vistas à sua maior durabilidade e facilidade de manutenção. In: Simpósio sobre patologia das edificações: prevenção e recuperação. UFRGS. Porto Alegre, 1989. p251-262.

FELIÚ, C. et al. Methodology for diagnosing pathologies in installed ceramic tile. In: World Congress On Ceramic Tile Quality, II. Castellón, 1992. Qualicer 92. Castellón, Camara Oficial do Comercio, Industria y Navegation, 1992. v.2, p.415-34.

FONTE, Antônio Oscar Cavalcanti; FONTE, Felipe Luna Freire; CASTILLO, Arlen Angélica Hilda Espinosa; PEDROSA, André Victor Alves da Costa. Características e parâmetros estruturais de edifícios de múltiplos andares em concreto armado construídos na cidade do Recife. In: 47음 Congresso Brasileiro do Concreto. IBRACON. Recife, 2005. pXII274-XII284.

FONTE, Felipe Luna Freire; FONTE, Antônio Oscar Cavalcanti. Análise de interação soloestrutura para diferentes soluções de fundação superficial em edifícios. In: V Simpósio EPUSP sobre Estruturas de Concreto. EPUSP. São Paulo, 2003.

GAO, Zhili; SMITH, Gary R.; MINCHIN JR., R.E. Budget and schedule success for small capitalfacility projects. Journal of Management in Engineering. v.18, n.3, 2002. p186-193.

GASPAR, Pedro; BRITO, Jorge. Mapping defect sensitivity in external mortar renders. Construction and Building Materials. v.19, 2005. p571-578.

GEHBAUER, Fritz. Racionalização na construção civil - como melhorar processos de produção e de gestão. Recife. Projeto Competir (Senai, Sebrae, GTZ), 2004. 448p.

GIOVINAZZO, Renata A. Modelo de aplicação de metodologia Delphi pela internet vantagens e ressalvas. Administração On Line, v.2, n.2, abr/mai/jun 2001. Disponível em: <http://www.fecap.br/adm_online/art22/renata.htm>. Acesso em: 07 set. 2007.

GOLDBERG, R.P. Revestimientos exteriores con adherencia directa de azulejos cerámicos, piedra y ladrillos caravista - Manual de diseño técnico. Laticrete International, 1998.

GOMIDE, Tito Lívio Ferreira. Técnicas de inspeção e manutenção predial. São Paulo: Editora Pini, 2006. 227p.

GRANDISKI, Paulo. Apostila do curso de perícias em edificações. São Paulo, 2002.

GRILO, Leonardo Melhorato; CALMON, João Luiz. Falhas externas em edificações multifamiliares segundo a percepção dos usuários. In: VIII Encontro Nacional de Tecnologia do Ambiente Construído - ENTAC. Cód. 385. Salvador, 2000. 
GUARDA, Mônica Cristina Cardoso; LIMA, Juliana Soares. Verificação dos deslocamentos em elementos fletidos - um panorama da nova NBR6118. In: V Simpósio EPUSP sobre Estruturas de Concreto. EPUSP. São Paulo, 2003.

HATUSH, Zedan; SKITMORE, Martin. Evaluating contractor prequalification data: selection criteria and project success factors. Construction Management and Economics. v.15, n.2, 1997. p129-147.

HOLANDA JR., Osvaldo Gomes; RAMALHO, Márcio Antônio; CORRÊA, Márcio Roberto Silva. Comportamento de um edifício de concreto armado considerando a interação solo-estrutura e o efeito incremental construtivo. In: 42 Congresso Brasileiro do Concreto. IBRACON. Fortaleza, 2000.

ISAIA, Geraldo Cechella, ed. Concreto: Ensino, pesquisa e realizações. São Paulo: IBRACON, 2005. 2v. p953-983.

KARAM, Talal Abi. Design/Build selection process - art or science? Cost Engineering. v.47, n.5, 2005. p14-19.

KAYO, Eduardo Kazuo; SECURATO, José Roberto. Método Delphi: fundamentos, críticas e vieses. Cadernos de Pesquisa em Administração, São Paulo. v.1, n.4, 1997. p51-61.

KUMAR, Pankaja Pradeep. Effective use of Gantt Chart for managing large scale projects. Cost Engineering. v.47, n.7, 2005. p14-21.

LAVILLE, Christian, DIONNE, Jean. A construção do saber - manual de metodologia da pesquisa em ciências humanas. Adaptado por Lana Mara Simon. Trad.: Heloísa Monteiro e Francisco Settineri. Editora UFMG, Belo Horizonte, 1999.

LEE, R. Building Maintenance Management. 3.ed. London, William Collins Sons \& Co. Ltd., 1987.

LIBRELOTTO, Lisiane Ilha; FERROLI, Paulo César M.; RADOS, Gregório Varvakis. Custos na construção civil: uma análise teórica e comparativa. In: VII Encontro Nacional de Tecnologia do Ambiente Construído - ENTAC. Florianópolis, 1998. p399-406.

LICHTENTEIN, Norberto Blumenfeld. Patologia das construções: procedimentos para formulação de diagnóstico de falhas e definição de conduta adequada à recuperação de edifícios. São Paulo, 1985. Dissertação (Mestrado) - Escola Politécnica da Universidade de São Paulo.

LORDSLEEM JR., Alberto Casado; NEVES, Maria Luiza Rodrigues; LOPES, Rodrigo F.; MONTEIRO, Eliana Cristina Barreto. Tecnologia Construtiva de renovação do revestimento de fachada em edifícios de múltiplos pavimentos. In: VI Encontro Tecnológico da Engenharia Civil e Arquitetura - ENTECA. Maringá, 2007. p.75.

MACCAFERRI, Paulo André. Manutenção de edifícios - contratação de um sistema para recuperação de revestimentos de fachadas. São Paulo, 2005. Monografia (Especialização em Tecnologia e Gestão da Produção de Edifícios) - Escola Politécnica da Universidade de São Paulo.

MANSUR, A.A.P.; NASCIMENTO, O.L.; MANSUR, H.S. Data Collection of five years of exterior façade pathologies in Brazil. In: XIII World Congress on ceramic tile quality - QUALICER. Castellón, 2006. p.BB-109 - 124. 
MARANHÃO, Flávio Leal; COSTA E SILVA, Angelo Just da; MEDEIROS, Jonas Silvestre; BARROS, Mércia Maria Semensato Bottura. Influência do tipo de argamassa colante e do revestimento na microestrutura e na resistência de aderência. In: V Simpósio Brasileiro de Tecnologia das Argamassas - SBTA. São Paulo, 2003. p495-504.

MASSAUD, Clóvis. Metodologia "Delphi". Disponível em: <http://www.clovis.massauad. nom.br/prospec.htm>. Acesso em: 07 set. 2007.

MATOS, Viviane Cavalcante de Mello; LIMA, Mariângela Geimbra. Manual para avaliação de fachadas - importância da avaliação dos fatores ambientais de degradação. In: XI Encontro Nacional de Tecnologia do Ambiente Construído - ENTAC. Florianópolis, 2006.

MEIRA, Alexsandra Rocha; HEINECK, Luiz Fernando. Manutenção em unidades privativas: quanto custa? In: X Encontro Nacional de Tecnologia do Ambiente Construído - ENTAC. São Paulo, 2004.

; HEINECK, Luiz Fernando. Estudo da manutenção e satisfação de moradores em condomínios residenciais de Florianópolis. In: IX Encontro Nacional de Tecnologia do Ambiente Construído - ENTAC. Foz do Iguaçu, 2002. p1433-1441.

MELHADO, Sílvio Burratino. Qualidade do projeto na construção de edifícios: aplicação ao caso das empresas de incorporação e construção. São Paulo, 1994. Tese (Doutorado) Escola Politécnica - Universidade de São Paulo.

MONACELLI, Fernando. Reforma geral das fachadas de um edifício revestido de placas cerâmicas: acompanhamento das diversas etapas dos serviços. São Paulo, 2005. Monografia (Especialização em Tecnologia e Gestão da Produção de Edifícios) - Escola Politécnica da Universidade de São Paulo.

OLIVEIRA, Cristiane Sardin Padilha; SILVA FILHO, Luiz Carlos Pinto; SIVIERO, Luís Artur; CAMPOS, Ricardo Francisco Szulczewski. Manutenção: estratégia para minimização de riscos de elementos de fachada. In: XI Encontro Nacional de Tecnologia do Ambiente Construído ENTAC. Florianópolis, 2006.

PARKER, Donald E. Project budgeting for buildings. Cost Engineering. v.36, n.10, 1994. p1318.

PEREZ, Ary Rodrigo. Manutenção dos edifícios. Tecnologia das Edificações. PINI, São Paulo. 1988. p611-614.

PERNAMBUCO. Lei no 13.032, de 14 de junho de 2006. Dispõe sobre a obrigatoriedade de vistorias periciais e manutenções periódicas em edifícios de apartamentos e salas comerciais. Pernambuco, 2006.

PETRUCCI, Helena M. Cabeda; DAL MOLIN, Dense C.C.; SILVA, Maria de Fátima Souza, SILVA, Reinaldo Roesch. Procedimento para levantamento de manifestações patológicas em revestimentos externos em argamassas. In: II Simpósio Brasileiro de Tecnologia das Argamassas - SBTA. Salvador, 1997. p334-343.

PORTO ALEGRE. Lei Ordinária no 6323, de 30 de dezembro de 1988. Estabelece critérios para a conservação de elementos nas fachadas dos prédios. Porto Alegre, 1988.

PRIORI JR, Luiz ; BRENNAND, Frederico; COSTA E SILVA, Angelo Just; OLIVEIRA, Romilde. Estudo sobre a qualidade da cal produzida em Pernambuco e sua influência nas argamassas. 
In: XI Encontro Nacional de Tecnologia no Ambiente Construído - ENTAC, 2006, p. 42994308.

PIETROFORTE, Roberto; ABOULEZZ, Mohamed. ASCE Journal of Management in Engineering: review of years 1985-2002. Journal of Management in Engineering. v.21, n.3, 2005. p125-130.

PITHAN, Denise Nunes; AZAMBUJA, Marcelo Menna Barreto; FORMOSO, Carlos Torres; BARROS NETO, José de Paula. Caracterização da produção científica de áreas de conhecimento específicas: aplicação à gestão e economia da construção. Ambiente Construído. v.5, n.3, 2005. p7-18.

RESENDE, Maurício Marques. Manutenção preventiva de revestimentos de fachada de edifícios: limpeza de revestimentos cerâmicos. São Paulo, 2004. Dissertação (Mestrado) Escola Politécnica da Universidade de São Paulo.

RICHARDSON, Roberto Jarry e colaboradores. Pesquisa social: métodos e técnicas. São Paulo, Atlas, 1999. 334p.

RUANO, Roberto Paredes. Importancia de una metodología de investigación en los trabajos de patología, diagnóstico y rehabilitación de edificios. In: VII Congresso Ibero-Americano de Patologia das Construções - CONPAT. Porto Alegre, 1997. p685-692.

SABBATINI, Fernando Henrique. As fissuras com origem na interação vedação-estrutura. In: I Seminário tecnologia e gestão na produção de edifícios: vedações verticais. EPUSP/PCC. São Paulo, 1998. p169-186.

SANTOS, Adriana de Oliveira; SCHMITT, Carin Maria. Estudo exploratório sobre o conteúdo dos manuais de operação, uso e manutenção de edificações desenvolvidos por empresas do Rio Grande do Sul e Alagoas frente às diretrizes da NBR 14.037/98 e as expectativas dos usuários. In: X Encontro Nacional de Tecnologia do Ambiente Construído - ENTAC. São Paulo, 2004.

SANTOS, Aguinaldo; VIDOTTO, Lisiane Soldateli; GIUBLIN, Carlos Roberto. A utilização do método Delphi em pesquisas na área de gestão da construção. Ambiente Construído. v.5, n.2, 2005. p51-59.

SANVIDO, Victor; RIGGS, Leland. Managing successful retrofit projects. Cost Engineering. v.35, n.12, 1993. p25-31.

SITTER, W.R. Costs for Service Life Optimization the "Law of Fives". Comite Euro International du Beton. Copenhagen, Denmark, n.152, 1983. p.131-134.

SILVA, Marcos Alberto Ferreira da; CARVALHO, Roberto Chust; FIGUEIREDO FILHO, Jasson Rodrigues. Principais modelos de cálculo utilizados na análise estrutural de edificações. In: V Simpósio EPUSP sobre Estruturas de Concreto. EPUSP. São Paulo, 2003.

SÖNMEZ, M.; HOLT, G.D.; YANG, J.B.; GRAHAM, G. Applying evidential reasoning to prequalifying construction contractors. Journal of Management in Engineering. v.18, n.4, 2002. p111-119.

TABORDA, Rui Pessanha; SOEIRO, Alfredo. Análise de patologias - metodologia de quantificação "causa-efeito". In: 2 Encontro Sobre Conservação e Reabilitação de Edifícios - ENCORE. LNEC. Lisboa, 1994. p807-811. 
TENAH, Kwaku A. The design-build approach: an overview. Cost Engineering. v.42, n.3, 2000. p31-37.

TÔRRES, Marco Antônio Gonçalves; PINTO, Nelson Guedes Ferreira. Responsabilidade civil do construtor: noções básicas. In: VI SIMEAP: Danos na construção civil - responsabilidades do construtor, do usuário, prazos e garantias, 2000. Disponível em: <http://www.imape.com.br>. Acesso em: 16 jan. 2006.

TURATO, Egberto Ribeiro. Tratado da metodologia da pesquisa clínico-qualitativa: construção teórico-epistemológica, discussão comparada e aplicação nas áreas da saúde e humanas. 2ed. Petrópolis. Editora Vozes, 2003. 685p.

VAN VLIET, Willem. So what if housing research is thriving? Researcher's perceptions of the use of housing studies. Journal of Housing and the Built Environment. v.18, 2003. p183-199.

VERÍSSIMO, Francisco Salvador; BITTAR, William S.M.. 500 anos da casa no Brasil. 2ed., Ediouro, Rio de Janeiro. 1999. 142p.

VIEIRA NETTO, Antônio. Como gerenciar construções. São Paulo, Pini, 1988. 119p.

YIU, C.Y.; LO, S.M.; NG, S. T.; NG, M.M.F. Contractor selection for small building works in Hong Kong. Structural Survey. v.20, n.4, 2002. p129-35.

WRIGHT, James Terence Coulter; GIOVINAZZO, Renata Alves. Delphi - uma ferramenta de apoio ao planejamento prospectivo. Caderno de Pesquisas em Administração, São Paulo. v.1, n.12, 2000. p54-65.

ZELOUF, Nissim. Building alteration and renovation versus demolition and new construction - A study in the economical feasibility of government construction. Cost Engineering. v.34, n.3, 1992. p21-23. 
ANEXO A - REGISTRO FOTOGRÁFICO DOS CASOS APRESENTADOS NA FASE EXPLORATÓRIA 


\section{EDIFÍCIO A}

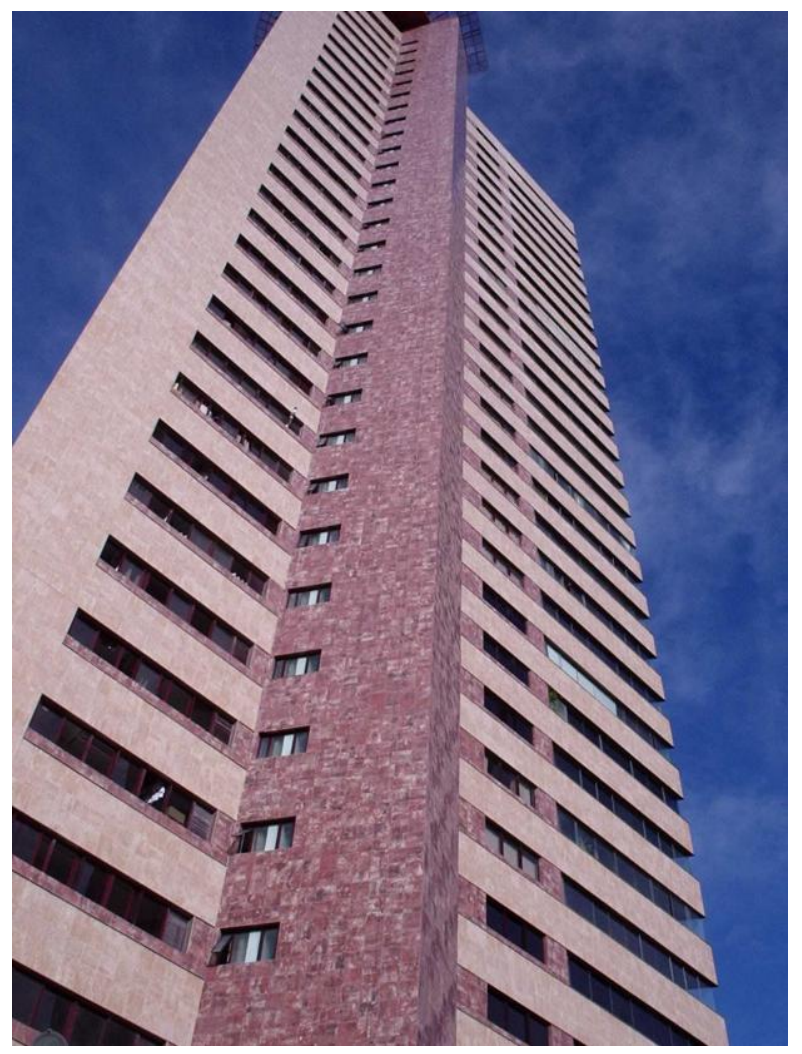

Figura 14 - Vista geral da fachada sul e caixa de escada (concluído - janeiro 2005).

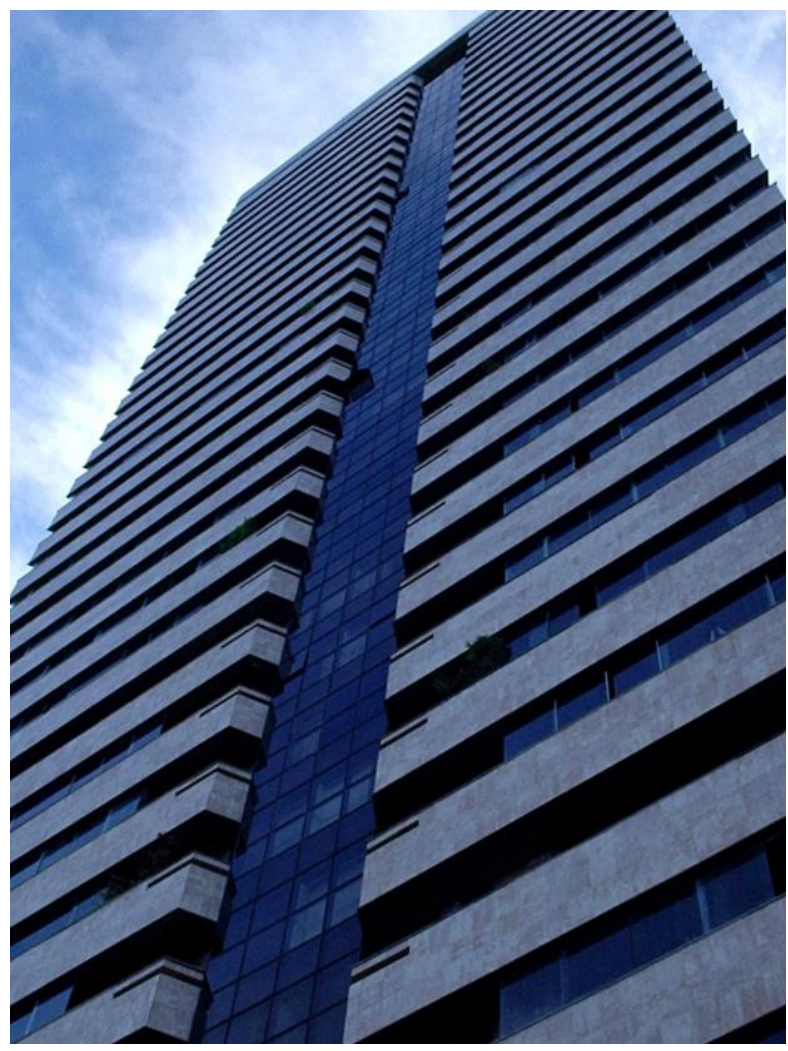

Figura 15 - Vista geral da fachada leste (concluído - janeiro 2005). 


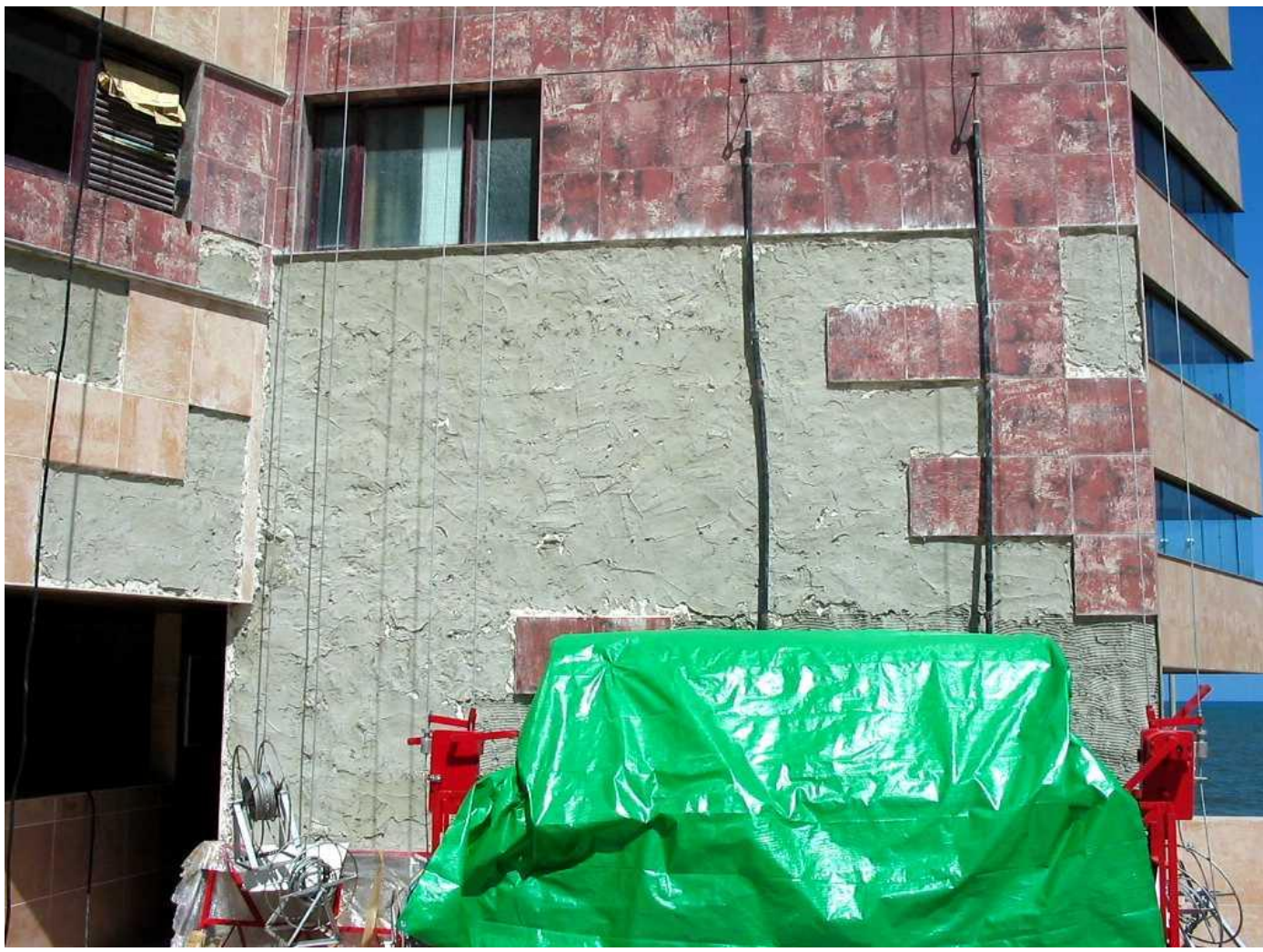

Figura 16 - Detalhe da recomposição do revestimento em procelanto.

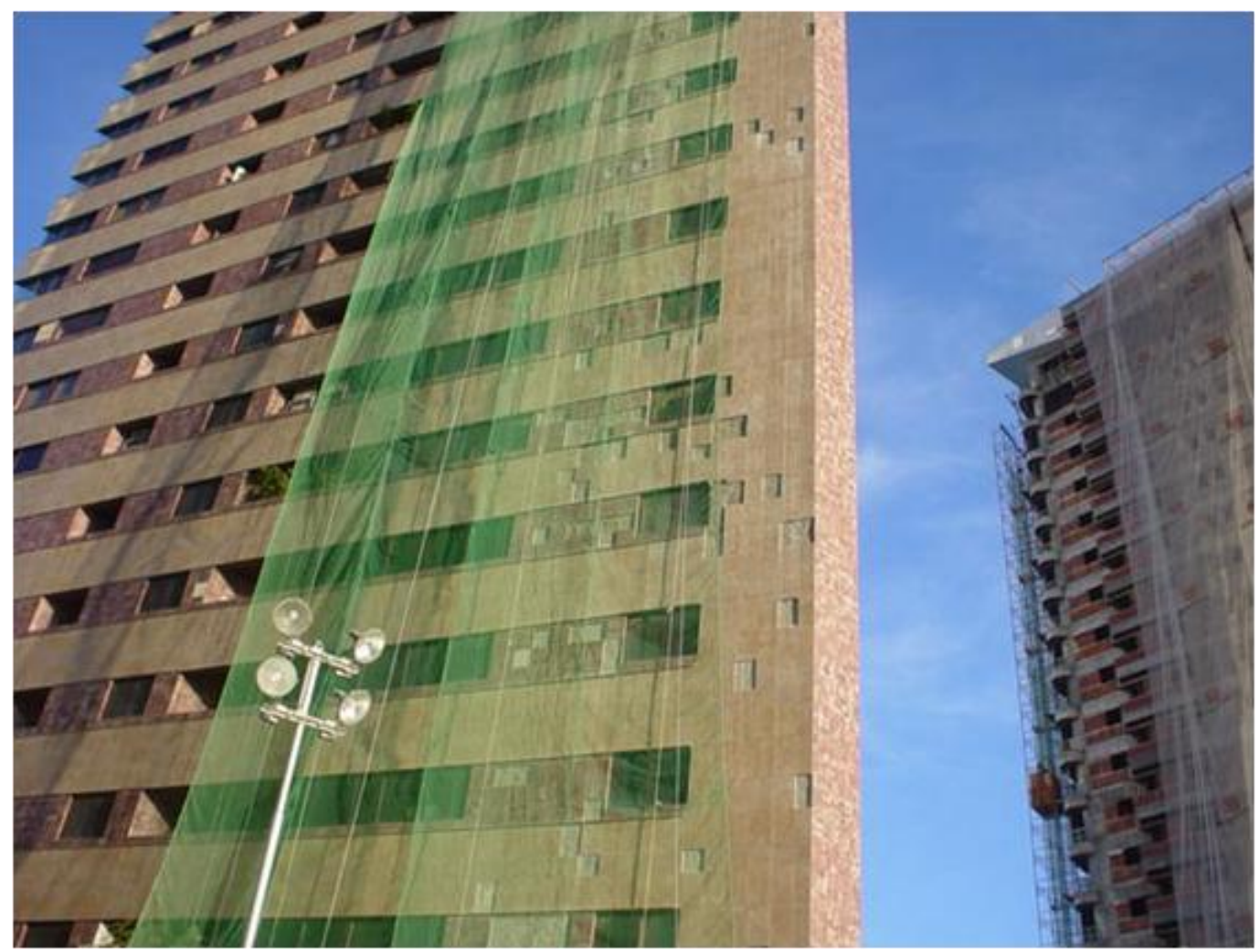

Figura 17 - Vista da fachada norte durante a obra (setembro de 2003). 


\section{EDIFÍCIO B}

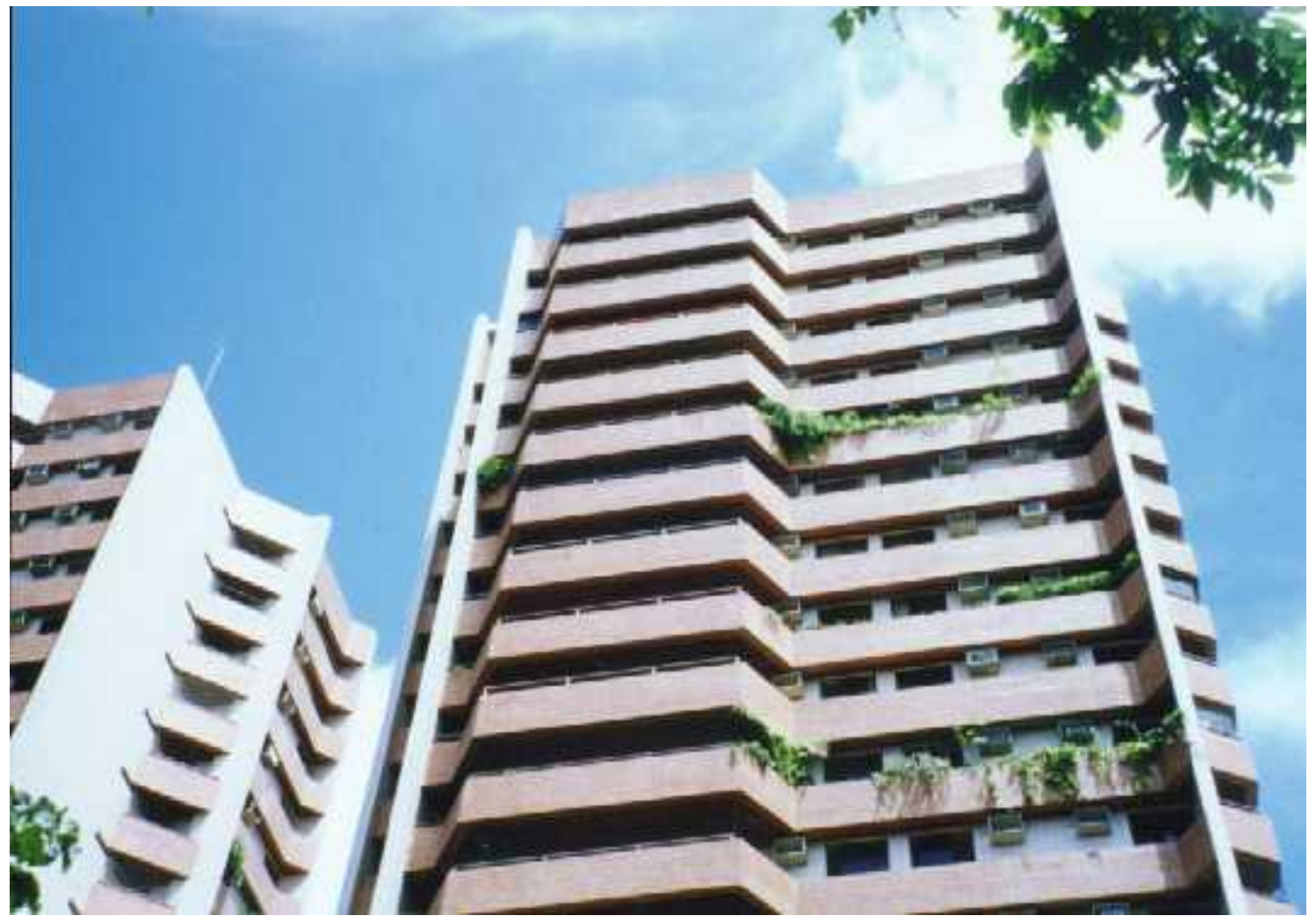

Figura 18 - Vista geral da fachada principal (original).

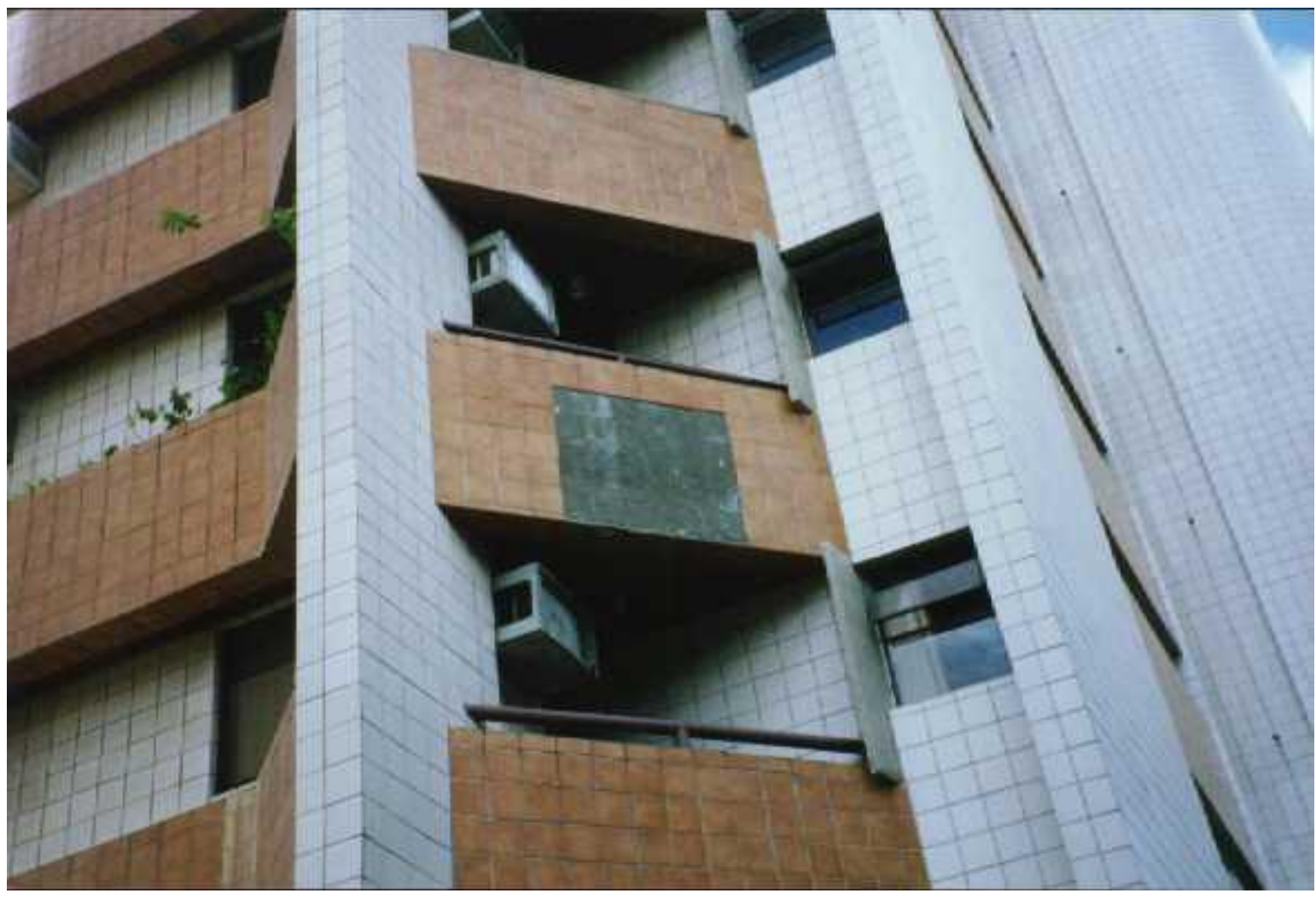

Figura 19 - Detalhe de trecho com queda do revestimento cerâmico da varanda. 


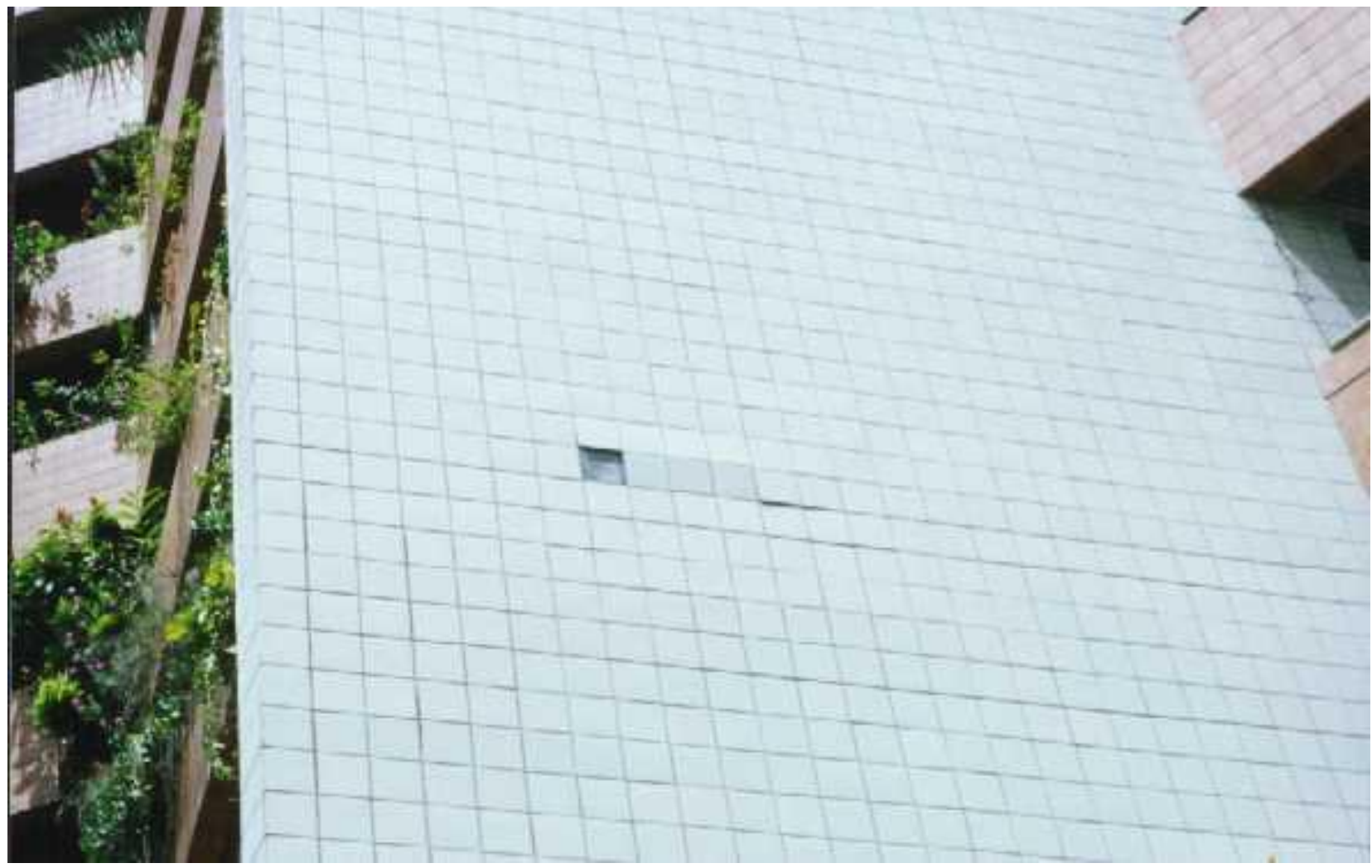

Figura 20 - Aspecto de trecho com estufamento do revestimento cerâmico original. 


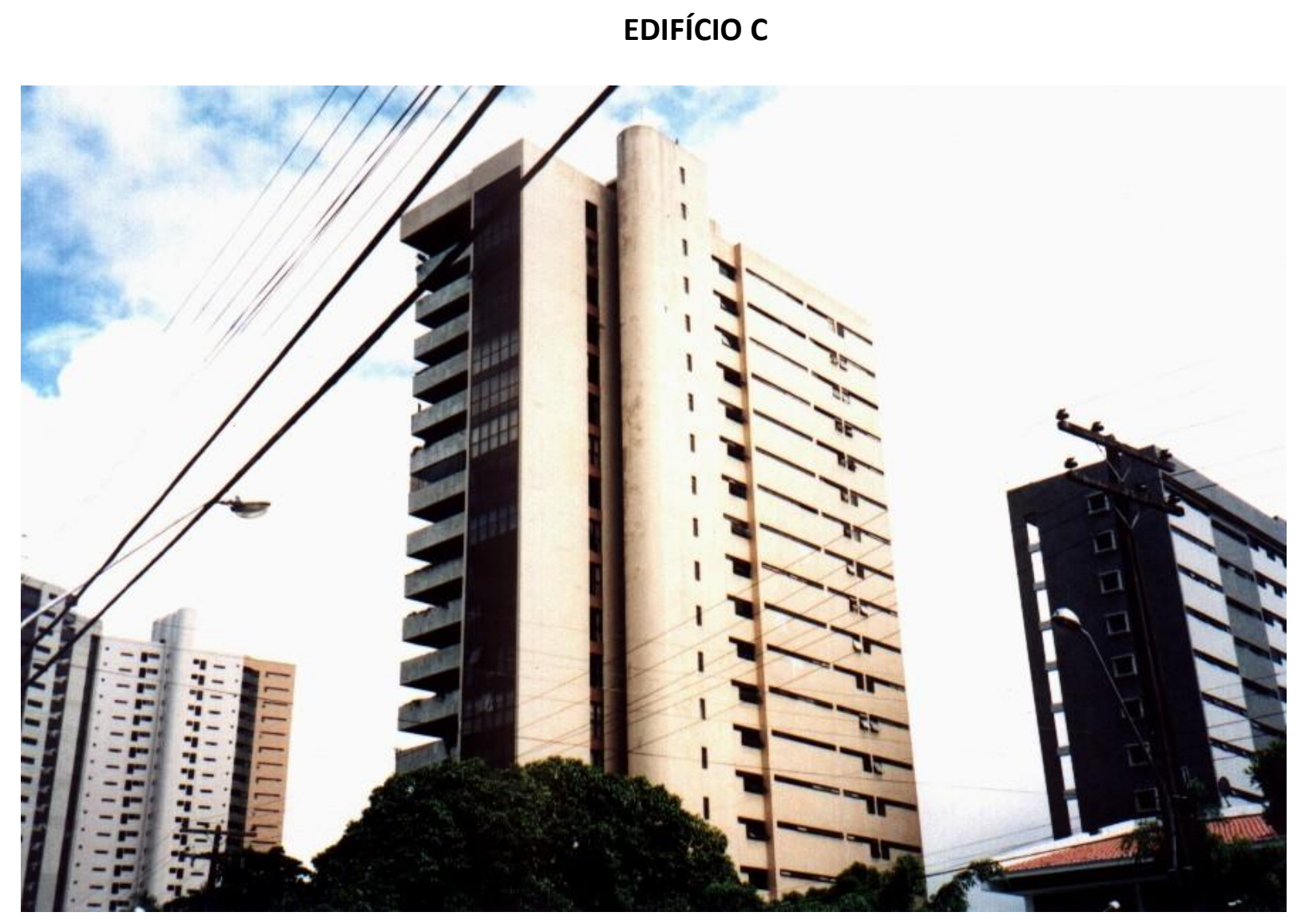

Figura 21 - Vista geral da fachada norte original (junho 2003).

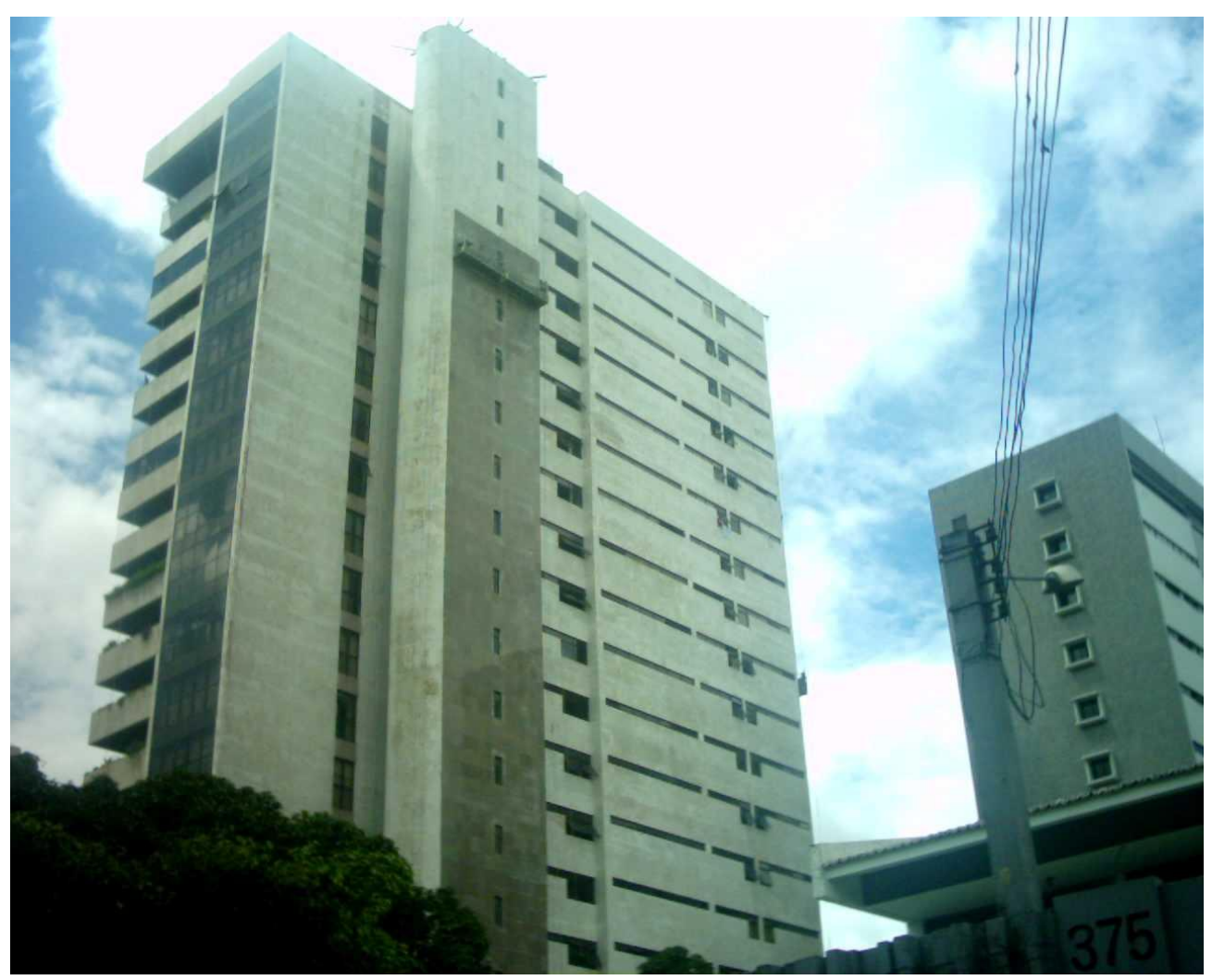

Figura 22 - Execução do revestimento caixa de escada fachada norte (agosto 2004). 


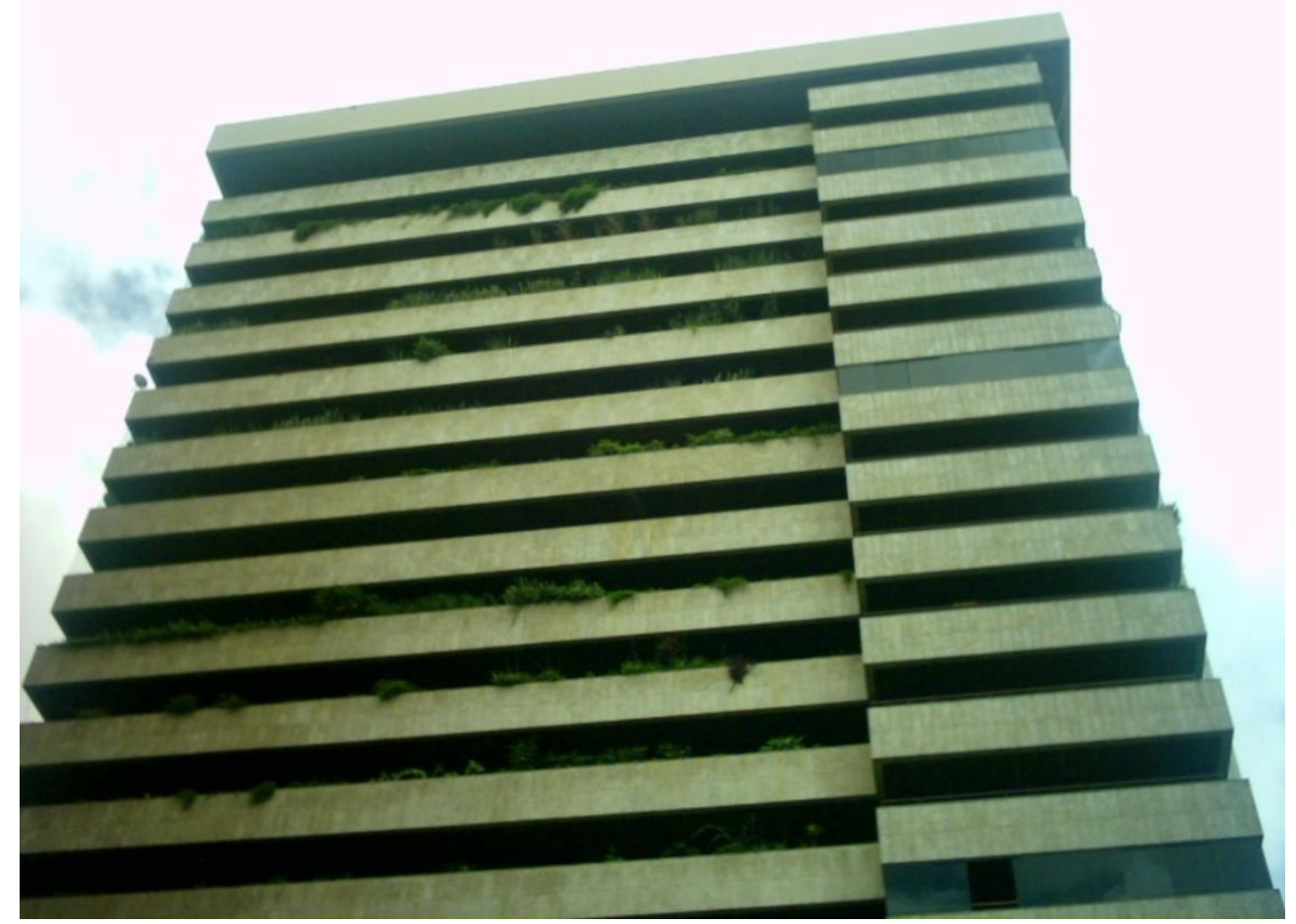

Figura 23 - Vista geral da fachada sul (original com limpeza - agosto 2004).

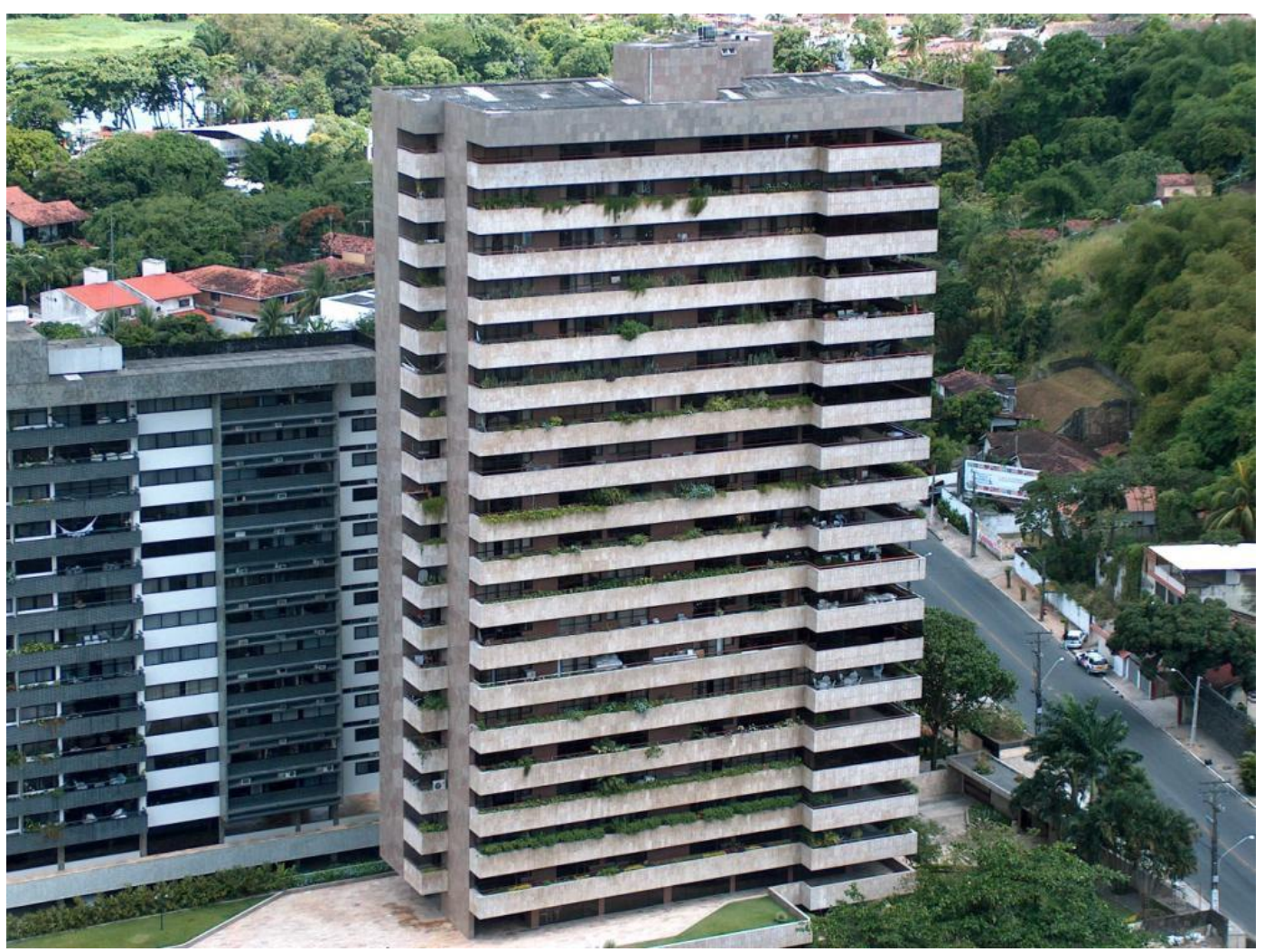

Figura 24 - Vista geral das fachadas sul e leste e área social mezanino (concluído - dezembro 2004). 


\section{EDIFÍCIO D}

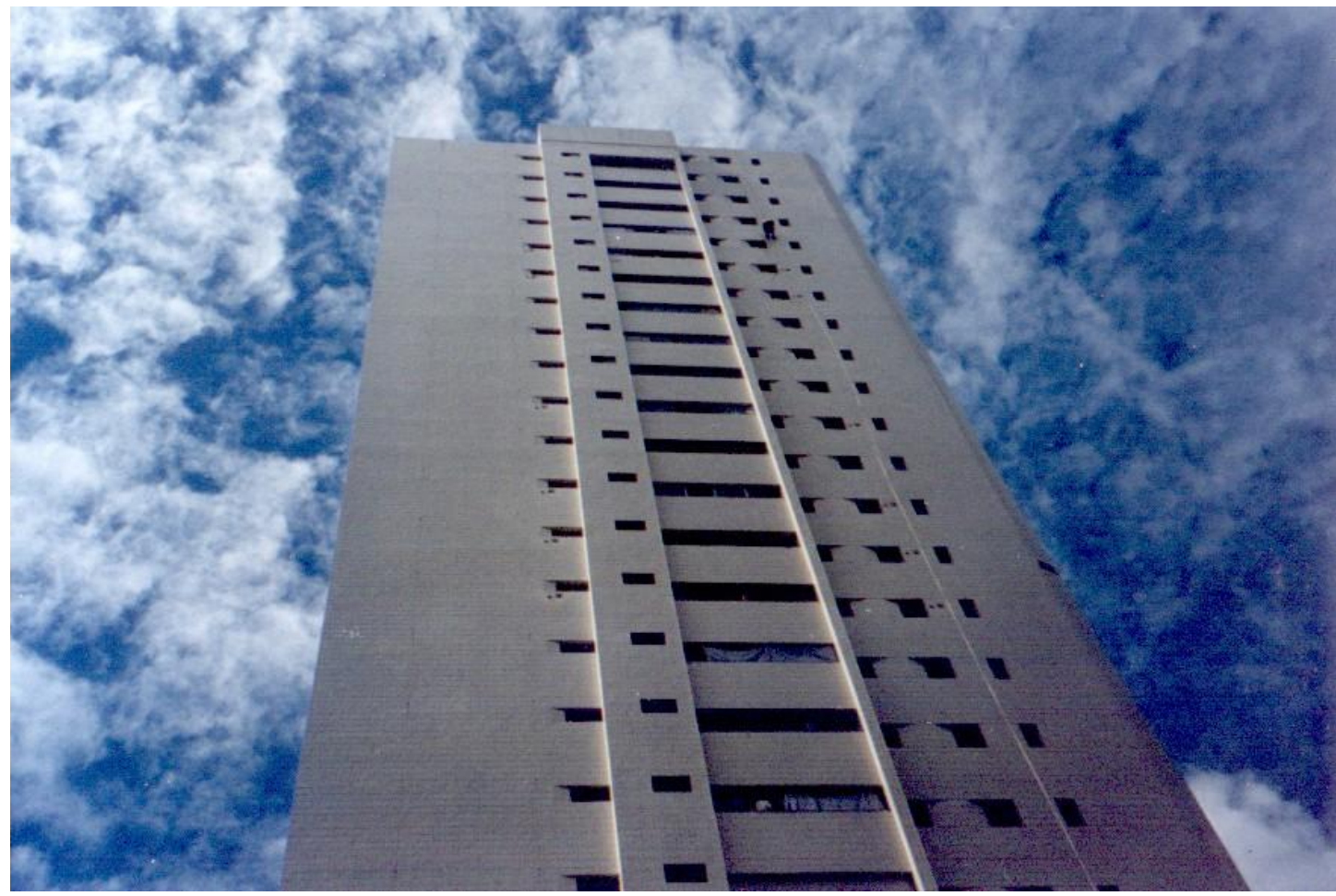

Figura 25 - Vista da fachada leste (poente).

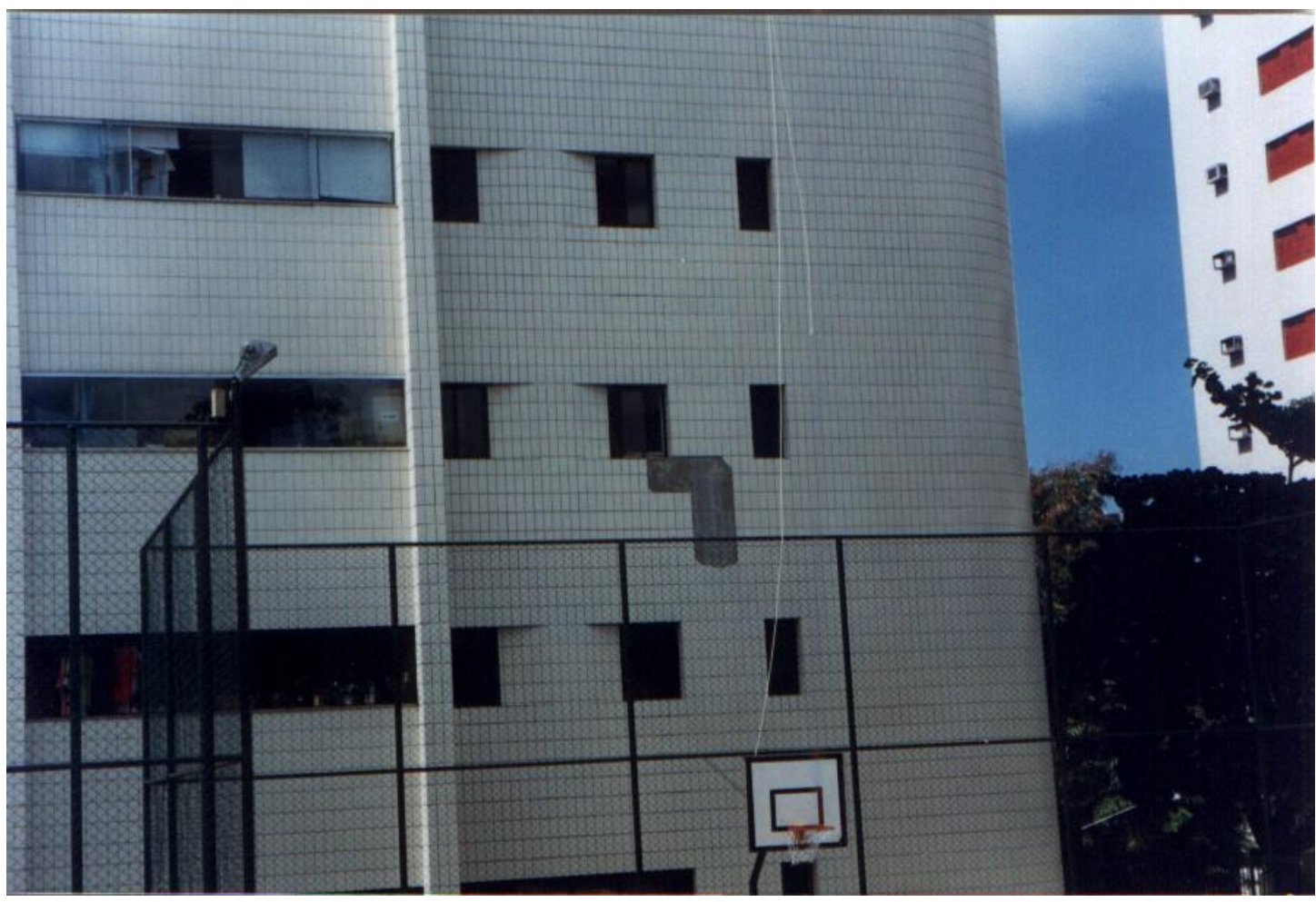

Figura 26 - Detalhe de trecho da fachada poente com queda de revestimento cerâmico. 
ANEXO B - DIAGRAMAÇÃO DO SITE UTILIZADO NA PESQUISA 


\begin{tabular}{|c|c|} 
ESCOLA POUTÉCNCA DA UNVERSIDADE DE SÕOPAULO \\
Popartamento de Engenharia de Construção Civil -PCC \\
Pósaduação emEngenharia de Construção Civil e Urbana-PG-ECCUR
\end{tabular}

\begin{tabular}{|c|c|}
\hline $\begin{array}{l}\text { Usuário: } \\
\text { Senha: }\end{array}$ & $\begin{array}{l}\text { VAUDAÇÕOINIERNA DE CONIEÛDO-CONSULTA A ESPECIAUSTAS } \\
\text { Esse site temo objetivo de coletar informações junto a especialistas (selecionados mediante critérios } \\
\text { de escolha pré definidos) na área de construção civil a respeito do tema manutenção em obras de } \\
\text { recuperação de fachadas, sendo parte integrante de uma tese de doutorado em desenvolvimento na } \\
\text { Escola Politécnica da Universidade de São Paulo, sob a coordenação do Eng }{ }^{\circ} \text { Angelo Just da Costa e } \\
\text { Silva e a orientação do Prof. Dr. Luiz Sérgio Franco. } \\
\text { MÉTODODA PESQUISA }\end{array}$ \\
\hline 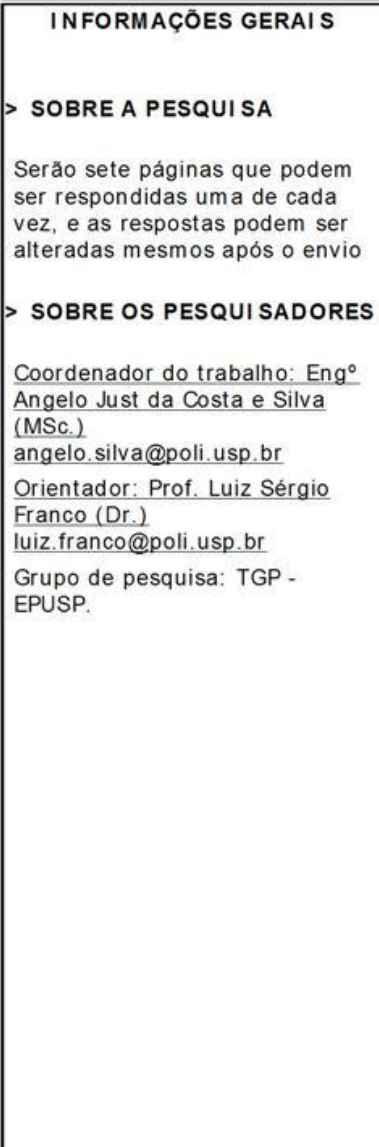 & 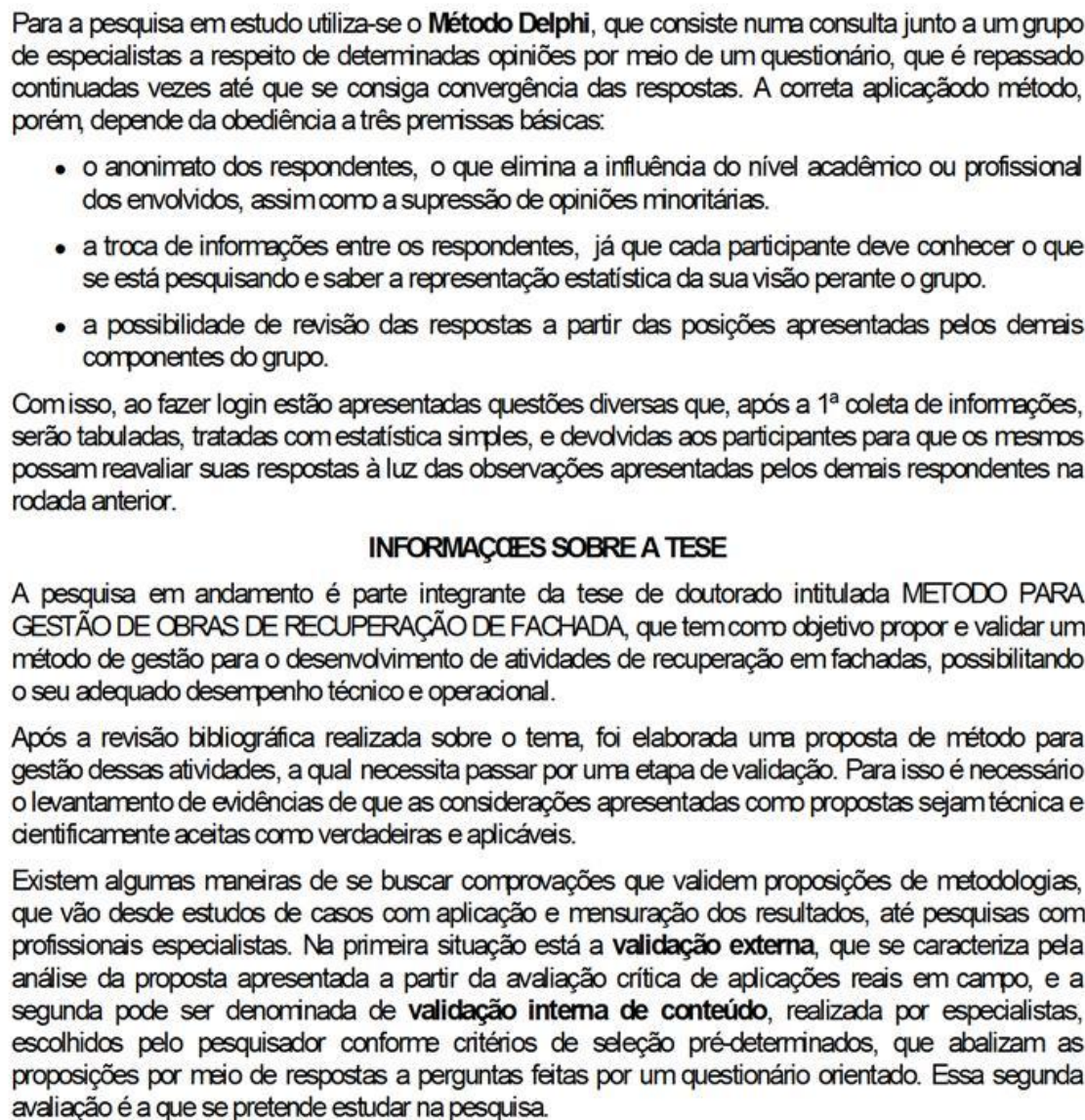 \\
\hline
\end{tabular}


ANEXO C - EXEMPLO DE CARTA CONSULTA (DOCUMENTO DE INTENÇÕES) 


\section{ITEM 1 - APRESENTAÇÃO}

A carta consulta tem por objetivo estabelecer as condições técnicas a serem observadas na execução dos serviços da substituição do revestimento cerâmico de fachada no Edf. Modelo, a serem contratados pelo condomínio do referido edifício.

As condições técnicas se referem ao fornecimento de mão-de-obra, materiais, ferramentas e equipamentos necessários à execução dos serviços.

Prazo de execução das obras - as propostas deverão ser apresentadas para o prazo de 12 meses.

Qualquer tipo de alteração, técnica ou comercial, sugerida pela empresa concorrente, deverá ser efetuada por meio de documento formal impresso e entregue junto com a proposta encaminhada ao CONDOMÍNIO, doravante também denominado de CONTRATANTE. Condomínio.

O presente texto foi submetido à análise e aprovação da Comissão de Reforma do

\section{ENTREGA E ESCLARECIMENTOS}

A proposta deverá ser endereçada ao Condomínio, em atenção à Comissão de Reformas, assinada pelo representante legal e também pelo responsável técnico da empresa, devidamente identificados.

\section{REGIME CONTRATUAL, PAGAMENTO, RETENÇÕES E REAJUSTAMENTO}

A proposta deverá explicitar textualmente as seguintes condições, ora definidas:

- Prazo de execução máximo: 12 (doze) meses;

- Validade da proposta: até 60 (sessenta dias) após a entrega da proposta;

- O pagamento será efetuado da seguinte maneira:

- Taxa de mobilização: 5\% do valor contratado, pago na assinatura do contrato.

- Durante o transcorrer da obra (12 meses): ocorrerão medições quinzenais, com pagamentos correspondentes a $65 \%$ do valor medido.

- Após a conclusão da obra: Os 30\% restantes serão pagos em 12 parcelas iguais mensais.

Reajustamento: não haverá reajustamento. Os preços deverão incluir, proporcionalmente, o eventual impacto financeiro do próximo dissídio coletivo da categoria;

O condomínio se compromete a efetuar o pagamento até 10 (dez) dias úteis após a aprovação da fiscalização. Todos os pagamentos somente ocorrerão com a entrega dos seguintes documentos ao condomínio, que terão a sua autenticidade e conferência aprovados pela empresa fiscalizadora:

- Nota Fiscal de serviços original.

- Folha de pagamento do período correspondente, em cópia autenticada.

- Comprovante do pagamento de GPS (Guia de recolhimento da Previdência Social INSS) do período correspondente, conforme disciplinado pela Instrução Normativa 
do INSS № 100/2003 ou outra que a atualize, em cópia autenticada. A critério da CONTRATANTE, o encargo previdenciário poderá ser retido na fonte e pago ao INSS, e depois repassada a guia de recolhimento original à empresa CONTRATADA.

- Comprovante do pagamento de GFIP (Guia de recolhimento do FGTS e de Informações à Previdência Social), em cópia autenticada.

Serão retidos na fonte os impostos ISS e IRRF, de acordo com a legislação vigente, no caso do ISS, conforme o Código Tributário Municipal do Recife e no caso do IRRF, conforme o Código Tributário Nacional.

A CONTRATANTE se responsabilizará pelo pagamento dos valores retidos na fonte e pelo repasse dos comprovantes originais à empresa.

\section{DO PRIMEIRO PAGAMENTO}

O primeiro pagamento à CONTRATADA somente dar-se-á com a entrega dos seguintes documentos:

- Anotação de Responsabilidade Técnica (ART) perante o CREA-PE, específica para a execução dos serviços contratados em regime de empreitada global, em via do CONTRATANTE.

- Matrícula CEI da obra no INSS (CEI - Cadastro Específico no INSS), em cópia autenticada.

\section{APRESENTAÇÃO DAS PROPOSTAS}

A proposta deverá ser apresentada em 02 (duas) vias, com todas as páginas rubricadas, assinadas ao final pela PROPONENTE, contendo as condições comerciais para execução da referida obra no prazo estipulado, incluindo o abaixo discriminado:

- Preço total dos serviços, contemplando o fornecimento de materiais e mão de obra (exceto as placas cerâmicas), encargos comerciais, fiscais, previdenciários e trabalhistas (vale-transportes ou quaisquer outros benefícios legais e complementares definidos em dissídio coletivo), inclusive ferramentas e equipamentos (inclusive fios, cabos e chaves para ligações elétricas, discos de cortes, brocas, lixas, esponjas, aplicadores, etc.), equipamentos de segurança (coletivo e individual, inclusive telas de proteção, bandejas, passarelas, etc.), transportes (interno, externo, vertical e horizontal), montagem, desmontagem, mão-de-obra de operação dos equipamentos/ferramentas, remoção de entulhos e limpeza permanente, necessários à correta execução de todos os serviços previstos, fornecendo os preços unitários e globais de cada um dos serviços e o preço global da obra.

- Cronograma físico da obra, dentro do prazo estipulado.

A CONTRATANTE será responsável pela aquisição e fornecimento das placas cerâmicas utilizadas na obra, ficando a CONTRATADA isenta de qualquer responsabilidade referente à qualidade desse material.

A contratação dar-se-á por instrumento de contrato, respeitadas as condições definidas nesta Carta Consulta e outras acordadas entre as partes. O foro da cidade é competente para dirimir qualquer questão contratual. 
A apresentação da proposta pela empresa não constitui qualquer compromisso entre a proponente e o Condomínio, inclusive, em nenhuma hipótese, haverá pagamento de despesas referentes à elaboração do orçamento e/ou proposta. Ao Condomínio reserva-se o direito de escolha de qualquer proposta a ser apresentada.

Uma vez apresentada a proposta, implica na aceitação de todas as condições estabelecidas nesta Carta Consulta e seus anexos.

\section{PREENCHIMENTO DAS PLANILHAS}

Não serão aceitos depois da assinatura do contrato, quaisquer preços suplementares devido a serviços não previstos no escopo, que serão considerados incluídos no preço global apresentado. As especificações a serem seguidas constam do caderno de especificações desta consulta.

\section{CONSIDERAÇÕES GERAIS}

Após a entrega da proposta não serão aceitas solicitações de modificação de valor, de quantidades, de especificação ou dos preços contratuais, sob quaisquer alegações da CONTRATADA.

Esta carta consulta e seus anexos passarão, em todos os seus termos, a fazer parte integrante do contrato a ser celebrado entre as partes. Fachada.

Só serão admitidos subempreiteiros com autorização da Comissão de Reforma da

\section{INÍCIO DOS SERVIÇOS}

Antes da contratação, e no prazo definido em carta-convocação, a construtora selecionada deverá entregar ao Condomínio os seguintes documentos, em cópias autenticadas, todas com validade (a contratação somente ocorrerá após a apresentação da documentação exigida):

- Contrato Social e última alteração da Junta Comercial;

- Cadastro Nacional de Pessoa Jurídica - CNPJ, emitido pelo Ministério da Fazenda;

- Comprovante de regularidade com as fazendas Federal, Estadual e Municipal;

- Certidão Negativa de Débito - CND com o INSS - Instituto Nacional de Seguro Social;

- Certificado de Regularidade de Situação - CRS com o FGTS - Fundo de Garantia por Tempo de Serviço;

- Certidão de Registro e Quitação - CRQ com o CREA - Conselho Regional de Engenharia, Arquitetura e Agronomia;

- Declaração, assinada pelo sócio-gerente, informando a parcela do capital social que está livre e desembaraçada de qualquer tipo de passivo, na data da proposta, de forma que possa ser considerado como lastro e garantia da responsabilidade civil da empresa.

A CONTRATADA deverá iniciar os serviços num prazo máximo de 15(quinze) dias úteis, contados a partir da data de assinatura do contrato. 
Para o início da execução dos serviços é obrigatória a presença na obra de, pelo menos, 03 (três) balancins de 6,00 metros instaladas, assim como as telas de nylon para proteção e demais elementos de segurança (bandejas de proteção, sinalizadores de isolamento etc.). 


\section{ITEM 2 - ESCOPO DOS SERVIÇOS A REALIZAR}

O presente item tem o objetivo de definir a especificação dos materiais e os procedimentos de produção a serem empregados nas atividades diversas, a seguir apresentados.

\section{SERVIÇOS PRELIMINARES}

Deverá ser implantada instalação provisória constando de almoxarifado, escritório da CONTRATADA, vestiário e refeitório, em local a ser definido pela CONTRATANTE.

\section{ATIVIDADES A SEREM REALIZADAS \\ REMOÇÃO DA CERÂMICA ORIGINAL}

Retirada cuidadosa das cerâmicas originais, por meio de talhadeira, de modo a se evitar maiores transtornos aos moradores e risco de acidentes com as peças soltas. Remover também a argamassa utilizada para o assentamento da cerâmica original, por meio de disco com lixa ou outro equipamento apropriado. A argamassa original de emboço também deve ser removida em todos os pontos onde a mesma se apresentar com som cavo, quando percutida. Nesse caso, a remoção deve ser feita até que se atinja a superfície da base (alvenaria ou concreto).

\section{TRATAMENTO DA ARGAMASSA DE EMBOÇO ORIGINAL}

Regularização da superfície original com argamassa de emboço para uso em revestimento externo ou por meio de argamassa colante tipo ACII ou ACIII. Além disso, a cada pavimento, na região de encontro entre o fundo da viga e a alvenaria deverá ser efetuada abertura, por meio de disco de corte, para posterior colocação das juntas de movimentação. $O$ corte deverá atingir uma profundidade mínima de $30 \mathrm{~mm}$, com largura de $12 \mathrm{~mm}$.

\section{ASSENTAMENTO DAS PLACAS CERÂMICAS}

Aplicação do revestimento cerâmico, seguido das atividades de rejuntamento, colocação das juntas e limpeza da fachada. Os procedimentos básicos a serem seguidos estão descritos a seguir:

- Utilização de argamassa colante tipo ACIII ou específica para uso em fachada indicada pelo fabricante;

- Após a mistura da argamassa colante com a água, na quantidade recomendada pelo fabricante, e concluídos os 15 minutos mínimos para a diluição dos aditivos, estender panos de, no máximo, $1,00 \mathrm{~m}^{2}$ por vez;

- Utilização de desempenadeira dentada com dimensões de $(8 \times 8 \times 8) \mathrm{cm}$, as quais devem ser substituídas quando os sulcos apresentarem profundidade inferior a $6 \mathrm{~mm}$;

- Execução dos panos com cerâmica;

- Percussão de cada peça cerâmica com martelo de borracha, a fim de garantir o total preenchimento do tardoz da cerâmica com argamassa colante.

- Remoção do excedente de argamassa colante nas laterais da placa para facilitar posterior aplicação do rejunte. 
- Utilização de rejunte industrializado, específico para fachada (tipo ARII), com propriedades de flexibilidade de baixa permeabilidade;

- Mistura da argamassa de rejunte com água, na quantidade recomendada pelo fabricante;

- Após a limpeza e secagem da junta, e decorridos 15 minutos para a diluição dos aditivos, aplicação do rejunte empurrando a argamassa de modo que se assegure o preenchimento completo da junta, sem falhas ou trincas;

- Remoção do excedente de argamassa de rejunte com pano seco ou espuma umedecida, assim que iniciar o seu endurecimento.

- Acabamento superficial com haste de madeira macia ou de plástico, com ponta arredondada e lisa.

\section{APLICAÇÃO DA JUNTA DE MOVIMENTAÇÃO}

Antes da aplicação das juntas será efetuada rigorosa limpeza da borda da cerâmica que irá receber o novo mastique, atendendo aos seguintes passos básicos:

- Proteção das placas cerâmicas ao longo das juntas utilizando fita crepe, a fim de não impregná-las com o mastique.

- Remoção, com disco de corte (maquita), de toda sujeira presente na borda da cerâmica a ser aderida.

- Colocação do material de enchimento (espuma de polietileno expandido - "tarucel"), garantindo que a espessura do selante esteja conforme a geometria original.

- Limpeza, com pano embebido em álcool isopropílico, da borda da cerâmica, seguida da passagem final de um pano seco.

- Aplicação do mastique elástico à base de poliuretano, utilizando bisnaga apropriada, com preenchimento desde o fundo até a superfície, evitando, desta forma, a oclusão de ar.

- Alisamento da superfície com ferramenta arredondada umedecida.

\section{LIMPEZA FINAL DA OBRA}

A entrega final do serviço deve ser feita com a fachada toda limpa, o que pode ser executado com uma passagem de esponja úmida, seguida de um pano seco. Todas as demais áreas sociais do condomínio também devem estar completamente isentas de sujeira antes da aprovação da última medição. Além disso, deverá ser realizada completa revisão da área de cobertura para reparo de qualquer dano ocorrido durante a execução da obra. 


\section{ITEM 3 - PLANILHA ORÇAMENTÁRIA}

As planilhas orçamentárias constantes da proposta comercial deverão contemplar todos os itens de serviços necessários à completa execução da obra.

Importante ressaltar que todas as atividades necessárias para a execução da obra deverão constar da proposta, mesmo aquelas não expressamente definidas na planilha apresentada pelo condomínio.

As propostas deverão ser apresentadas conforme o modelo e a seqüência a seguir. Qualquer alteração na planilha deve ser apresentada pela construtora à parte, em destaque:

PLANILHA DE REFERÊNCIA

\begin{tabular}{|c|c|c|c|c|c|}
\hline \multicolumn{6}{|c|}{ CONTRATADA } \\
\hline ITEM & DISCRIMINAÇÃO & UND & QTDE. & $\begin{array}{l}\text { PREÇO } \\
\text { UNIT. }\end{array}$ & PREÇO TOTAL \\
\hline 1 & SERVIÇOS PRELIMINARES & & & & \\
\hline 1.1 & Aluguel, montagem e desmontagem de balanças e instalações provisórias & mês & & & \\
\hline 1.2 & Taxa de mobilização de pessoal e equipamentos & $\mathrm{vb}$ & & & \\
\hline 1.3 & $\begin{array}{l}\text { Fornecimento e colocação de telas de proteção, inclusive emenda com corda e } \\
\text { fixação em coberta }\end{array}$ & $\mathrm{m}^{2}$ & & & \\
\hline 1.4 & $\begin{array}{l}\text { Proteção de janelas e varandas com tapumes de madeira e papelão, e } \\
\text { cobrimento das áreas sociais com lona plástica no térreo. }\end{array}$ & mês & & & \\
\hline 2 & DEMOLIÇÃO & & & & \\
\hline 2.1 & Demolição das placas incluindo remoção da argamassa colante do emboço & $\mathrm{m}^{2}$ & & & \\
\hline 2.2 & Remoção de pastilhas e resíduos de emboço (inclusive carga e transporte) & $\mathrm{m}^{3}$ & & & \\
\hline 3 & REVESTIMENTO & & & & \\
\hline 3.1 & $\begin{array}{l}\text { Regularização das superfícies com argamassa específica para fachada (inclui } \\
\text { fornecimento da argamassa) }\end{array}$ & $\mathrm{m}^{2}$ & & & \\
\hline 3.2 & $\begin{array}{l}\text { Aplicação de placa cerâmica tipo semi grês com argamassa ACIII (ou indicada } \\
\text { pelo fabricante como específica para uso em revestimento de fachada) no } \\
\text { processo convencional com desempenadeira de aço dentada (não inclui } \\
\text { fornecimentodacerâmical }\end{array}$ & $\mathrm{m}^{2}$ & & & \\
\hline 3.3 & $\begin{array}{l}\text { Fornecimento e aplicação de argamassa de rejunte industrializada, específica } \\
\text { para revestimento externo }\end{array}$ & $\mathrm{m}^{2}$ & & & \\
\hline 3.4 & $\begin{array}{l}\text { Realização de ensaios de resistência de aderência à tração direta em pontos } \\
\text { aleatórios espalhados pela fachada }\end{array}$ & und & & & \\
\hline 3.5 & Limpeza final do revestimento cerâmico & $\mathrm{m}^{2}$ & & & \\
\hline 4 & SERVIÇOS FINAIS - ENTREGA DA OBRA & & & & \\
\hline 4.1 & Desmobilização de balanças e instalações provisórias & $\mathrm{vb}$ & & & \\
\hline 4.2 & Limpeza final das áreas sociais com jato d'água & $\mathrm{m}^{2}$ & & & \\
\hline & & & SU & AL (F & \\
\hline & & & ENCA & S FISCA & \\
\hline & & & & TAL (R & \\
\hline
\end{tabular}




\section{ITEM 4 - DISPOSIÇÕES GERAIS PARA OS SERVIÇOS}

A CONTRATADA executará os serviços em estrita obediência às normas pertinentes da ABNT - Associação Brasileira de Normas Técnicas, oferecendo garantia de execução conforme Código Civil Brasileiro em vigência e conforme a Lei 8.078, de 11-09-1990 (que dispõe sobre a proteção do consumidor).

A CONTRATADA será responsável pela organização dos materiais na área do Condomínio, de forma: a não prejudicar o trânsito de pessoas e de veículos automotores; a não obstruir o acesso aos locais onde se encontram os equipamentos de combate a incêndio e portas/saídas de emergência.

O Condomínio fornecerá água e energia elétrica e indicará local para que a CONTRATADA execute instalações provisórias destinadas à guarda de equipamentos, ferramentas e alojamento diurno de funcionários da CONTRATADA. O elevador de serviço poderá ser utilizado pela CONTRATADA, em horários previamente acordados, resguardandose as boas normas de utilização, inclusive quanto aos limites de peso e de permanente limpeza. Caso o banheiro/sanitário de zeladoria existente não atenda às normas trabalhistas e/ou à demanda de utilização de funcionários da empresa executora dos serviços, a CONTRATADA deverá providenciar instalações provisórias adequadas, que serão pagas à parte, quando atestadas em boletim de medição, por preço que deverá ser apresentado na proposta da empresa.

Durante toda a execução do contrato, a CONTRATADA deverá manter as regularidades fiscais, jurídicas e técnicas determinadas pela legislação brasileira, isentandose o Condomínio de quaisquer descumprimentos ocorridos ou que venham a ocorrer.

A fiscalização técnica dos serviços será exercida pelo próprio condomínio, sendo obrigação da CONTRATADA acatar as determinações referentes à regularização das faltas e dos defeitos observados. O "Diário de Obras" será o instrumento adequado para o registro de ocorrências de ambas as partes. A fiscalização por parte do Condomínio não exclui ou reduz, em qualquer hipótese, a responsabilidade do contratado pela execução dos serviços.

A CONTRATADA é obrigada a reparar, corrigir, remover, reconstruir ou substituir, às suas expensas, no total ou em parte, o objeto do contrato em que se verificarem vícios, defeitos ou incorreções resultantes da execução do serviço ou de materiais empregados, inclusive quanto à incorreta aplicação da cerâmica.

Compete à CONTRATADA substituir os vidros de janela ou das portas das varandas quebrados em virtude de qualquer atividade relacionada com os serviços da obra, utilizando materiais com a mesma especificação dos originais. Todos os custos referentes a essa atividade ficarão a cargo da CONTRATADA.

A CONTRATADA deverá seguir rigorosamente as especificações constantes no presente documento, obrigando-se a garantir o perfeito andamento dos trabalhos, sua solidez, bom acabamento, assumindo as responsabilidades fixadas pelo Código Civil Brasileiro, efetuando quaisquer consertos e substituições necessárias em virtude de execução não adequada dos serviços objeto da presente consulta, livres de quaisquer ônus para a CONTRATANTE, assumindo inteira responsabilidade pelos materiais aplicados.

Entende-se que todos os materiais não especificados, instalações e mão-de-obra serão de melhor qualidade disponível no mercado, devendo ser aplicados ainda de acordo 
com as instruções dos respectivos fabricantes ou fornecedores. No que se refere aos materiais especificados, deverá ser observado rigorosamente as marcas, linhas e formas de aplicação especificadas, bem como as instruções do fabricante.

Qualquer modificação no projeto original somente poderá ser feita com a autorização do condomínio.

O recebimento definitivo da obra se dará somente após a aprovação de todos os serviços por parte do condomínio. 


\section{ITEM 5 - DISPOSIÇÕES GERAIS PARA O PESSOAL}

A CONTRATADA será obrigada a manter, em horário integral, mestre-de-obras (com experiência comprovada em serviços similares), sendo todos os serviços acompanhados por engenheiro civil (com experiência comprovada em serviços similares), o qual deverá inspecionar os serviços diariamente, sendo exigida a anotação em livro de registro de ocorrência - "Diário de Obras" (em duas vias, sendo uma via para o Condomínio e outra para a CONTRATADA).

A CONTRATADA será responsável por todos e quaisquer danos causados por seus funcionários (quer diretamente ao Condomínio, quer a terceiros), decorrentes de sua culpa ou dolo na execução do contrato, inclusive em revestimentos de pisos e paredes, esquadrias, vidros, telhados, veículos automotores, sendo também responsável pela remoção, lavagem e limpeza de respingos de argamassa ou de detritos/resíduos de quais produtos utilizados na execução dos serviços.

A CONTRATANTE não permitirá alojamento para pernoite de funcionários da construtora, nem o preparo de refeições nas dependências do Condomínio. Todos os funcionários da CONTRATADA deverão trabalhar uniformizados e portando crachás identificadores. A CONTRATADA entregará relação nominal e de endereços completos dos seus funcionários, com permanente atualização.

A CONTRATADA deverá manter em seu almoxarifado os equipamentos individuais de segurança necessários à sua equipe de empregados, sendo que o uso de capacete é obrigatório para entrar na obra.

A CONTRATADA deverá providenciar por sua conta o transporte e alimentação dos seus empregados. Não será permitido o preparo de refeições para os funcionários no canteiro de obras, e as mesmas devem ser fornecidas prontas para o consumo.

A CONTRATADA será responsável pela disciplina, boa ordem, comportamento e segurança de seus empregados. Por se tratar de edificação residencial em uso, deverão ser evitados ao máximo distúrbios sonoros durante a jornada normal de trabalho, não se admitindo estas ocorrências fora do horário de serviço.

A CONTRATADA impedirá que queixas ou reclamações que possam ser feitas por seus empregados sejam apresentadas à fiscalização, respondendo inteiramente por tudo o que ocorrer às suas relações com a citada parte, no decorrer dos serviços contratados.

A CONTRATADA deverá retirar, por determinação da CONTRATANTE, qualquer empregado ou preposto seu, cuja permanência no serviço seja julgada inconveniente. 


\section{ITEM 6 - MANUAL DE SEGURANÇA E HIGIENE PARA EMPRESAS CONTRATADAS}

Os principais aspectos relativos à segurança e higiene exigidos para as empresas contratadas estão descritas a seguir:

- É expressamente proibido fumar no interior da obra.

- Todas as atividades envolvidas no trabalho contratado devem obedecer às regras de segurança estabelecidas pela legislação em vigor dos Ministérios do Trabalho e da Previdência Social.

- Será obrigatório o uso de identificação individual, fardamento e equipamentos de segurança.

- Será proibido tomar bebidas alcoólicas durante o horário de trabalho. Será vedada a entrada, no canteiro, de pessoas em estado de embriaguês.

- As escadas de madeira deverão ser presas e possuir pás antiderrapantes. As escadas em mau estado serão destruídas.

- As instalações elétricas provisórias deverão ser feitas adequadamente, com os fios suspensos e suportados. As máquinas manuais deverão ser ligadas com plugs adequados e as máquinas fixas deverão ser ligadas com chaves em caixa de proteção.

- Nenhum empregado poderá trabalhar descalço, utilizando chinelos ou outro calçado inadequado ao trabalho.

- O local de trabalho deverá ser mantido sempre em perfeitas condições de limpeza, higiene e segurança, efetuando-se a remoção de toda e qualquer espécie de resíduo, constantemente.

- Para a instalação das balancins e demais elementos suspensos deve ser apresentado cálculo estrutural com registro de profissional responsável.

- Os equipamentos individuais de proteção deverão ser fornecidos pela CONTRATADA aos seus empregados.

- Para a execução de serviços em locais próximos à passagem de pessoas, as áreas devem ser isoladas e sinalizadas com placas.

- As áreas sociais de garagem e calçadas circundantes ao prédio devem permanecer, durante todo o transcorrer da obra, com aparato de proteção executado com andaime metálico e tapumes de madeira.

- As aberturas (janelas) e peitoris das varandas nas fachadas onde estiverem sendo executados serviços devem permanecer protegidos quanto a quebras e sujeiras com papelão ou compensado de madeira, a depender de cada situação.

- Ocorrendo qualquer fogo ou princípio de incêndio, comunicar imediatamente o chefe da obra, para os fins necessários.

- Somente pessoas autorizadas e capacitadas poderão utilizar máquinas, devendo antes de acioná-las, verificar as condições das mesmas, e se as proteções estão no devidos lugares. 
- Antes de acionar qualquer espécie de máquina, deve ser assegurado de que não há pessoas perto dela e que possam ser atingidas pelas partes móveis das mesmas.

- As áreas junto às máquinas deverão estar completamente limpas e desimpedidas.

- Antes de usar qualquer ferramenta, deve ser verificado seu estado e se é apropriada para o trabalho a ser executado.

- As ferramentas não deverão ser carregadas nos bolsos, nem ficar espalhadas pelo chão, abandonadas em escadas, plataformas, devendo ser transportadas em caixas apropriadas e manuseadas apropriadamente. Após o uso, verificar sempre as condições das mesmas, substituindo-as se necessário.

- As passagens e corredores onde se processam as obras deverão estar completamente livres, não devendo ficar obstruídos. Não serão admitidos pregos, parafusos, porcas, etc., pelo chão, devendo ser colocados em caixas apropriadas.

- Para serviços gerais de limpeza, devem ser empregados sempre os utensílios apropriados, ou seja, vassouras, escovas e outros.

- Antes de efetuarem-se trabalhos de limpeza em equipamentos, deve ser certificado de que as chaves elétricas estão desligadas e sem fusíveis, colocando ainda uma placa "NÃO LIGUE ESTA CHAVE", no painel e no botão de comando.

- Para proceder ao levantamento de objetos pesados, devem ser utilizados sempre os músculos das pernas, ficando as costas em posição vertical.

- Os equipamentos contra incêndio (hidrantes, extintores), bem como escadas e saídas, não devem ser obstruídos por qualquer espécie de material.

- Ao fim do dia de serviço, todos os locais de trabalho e os canteiros deverão ficar limpos e arrumados.

- Brincadeiras em serviço são proibidas. Não são permitidos jogos no canteiro de obras, mesmo no horário de almoço.

- É proibido utilizar materiais de combate a incêndio para outros fins ou remove-los dos locais onde se encontrarem.

- Os vestiários e sanitários deverão ser conservados limpos e arrumados.

- Não utilizar e depositar materiais inflamáveis de espécie alguma no interior da obra sem autorização da fiscalização.

- Estas são, em síntese, as "Normas Básicas de Segurança" a serem cumpridas. Além destas, deverão ser observadas todas as recomendações constantes da legislação em vigor, do Ministério do Trabalho. 